\title{
Race, Ethnicity and Nuclear War
}

Liverpool Science Fiction Texts and Studies, 40 


\title{
Liverpool Science Fiction Texts and Studies
}

\author{
Editor David Seed, University of Liverpool
}

Editorial Board

Mark Bould, University of the West of England

Veronica Hollinger, Trent University

Rob Latham, University of California

Roger Luckhurst, Birkbeck College, University of London

Patrick Parrinder, University of Reading

Andy Sawyer, University of Liverpool

Recent titles in the series

21. Andy Sawyer and David Seed (eds) Speaking Science Fiction: Dialogues and Interpretations

22. Inez van der Spek Alien Plots: Female Subjectivity and the Divine

23. S. T. Joshi Ramsey Campbell and Modern Horror Fiction

24. Mike Ashley The Time Machines: The Story of the Science-Fiction Pulp

Magazines from the Beginning to 1950

25. Warren G. Rochelle Communities of the Heart: The Rhetoric of Myth in the Fiction of Ursula K. Le Guin

26. S. T. Joshi A Dreamer and a Visionary: H. P. Lovecraft in his Time

27. Christopher Palmer Philip K. Dick: Exhilaration and Terror of the Postmodern

28. Charles E. Gannon Rumors of War and Infernal Machines:

Technomilitary Agenda-Setting in American and British Speculative Fiction

29. Peter Wright Attending Daedalus: Gene Wolfe, Artifice and the Reader

30. Mike Ashley Transformations: The Story of the Science-Fiction Magazine

$$
\text { from 1950-1970 }
$$

31. Joanna Russ The Country You Have Never Seen: Essays and Reviews

32. Robert Philmus Visions and Revisions: (Re)constructing Science Fiction

33. Gene Wolfe (edited and introduced by Peter Wright) Shadows of the New Sun: Wolfe on Writing/Writers on Wolfe

34. Mike Ashley Gateways to Forever: The Story of the Science-Fiction Magazine from 1970-1980

35. Patricia Kerslake Science Fiction and Empire

36. Keith Williams H. G. Wells, Modernity and the Movies

37. Wendy Gay Pearson, Veronica Hollinger and Joan Gordon (eds.) Queer Universes: Sexualities and Science Fiction

38. John Wyndham (eds. David Ketterer and Andy Sawyer) Plan for Chaos

39. Sherryl Vint Animal Alterity: Science Fiction and the Question of the Animal 


\title{
Race, Ethnicity and Nuclear War
}

\author{
Representations of Nuclear Weapons \\ and Post-Apocalyptic Worlds
}

\author{
PAUL WILLIAMS
}


First published 2011 by

Liverpool University Press

4 Cambridge Street

Liverpool

L69 7ZU

Copyright () 2011 Liverpool University Press

The right of Paul Williams to be identified as the author of this book has been asserted by him in accordance with the Copyright, Designs and Patents Act 1988.

All rights reserved. No part of this book may be reproduced, stored in a retrieval system, or transmitted, in any form or by any means, electronic, mechanical, photocopying, recording, or otherwise, without the prior written permission of the publisher.

British Library Cataloguing-in-Publication data

A British Library CIP record is available

ISBN 978-1-84631-708-8

Typeset by XL Publishing Services, Tiverton

Printed and bound by CPI Group (UK) Ltd, Croydon CR0 4YY 
It is such supreme folly to believe that nuclear weapons are deadly only if they're used. The fact that they exist at all, their very presence in our lives, will wreck more havoc than we can begin to fathom. Nuclear weapons pervade our thinking. Control our behaviour. Administer our societies. Inform our dreams. They bury themselves like meat hooks deep in the base of our brains. They are purveyors of madness. They are the ultimate colonizer. Whiter than any white man who ever lived. The very heart of whiteness.

Arundhati Roy, 'The End of Imagination' 



\section{Contents}

Acknowledgments viii

Introduction 1

1. Race, War and Apocalypse before 1945

2. Inverted Frontiers 49

3. Soft Places and Mad Max Beyond Thunderdome 85

4. Fear of a Black Planet 105

5. White Rain and the Black Atlantic 147

6. Race and the Manhattan Project 180

7. 'The Hindu Bomb': Nuclear Nationalism in The Last Jet-Engine Laugh 202

8. Third World Wars and Third-World Wars 224

$\begin{array}{ll}\text { Bibliography } & 251\end{array}$

$\begin{array}{ll}\text { Index } & 270\end{array}$ 


\section{Acknowledgments}

Above all, my thanks to Liverpool University Press: LUP's guidance was invaluable in steering my research into a finished book, particularly the contributions of Anthony Cond and the reviewers who read my proposal and manuscript. The final version is richer for their constructive criticism and suggestions for extending this research into writers, texts and debates I had not considered.

I continue to be grateful for the encouragement (intellectual and otherwise) of scholars working in the area of science fiction and related studies. Mark Bould, Sherryl Vint and Patrick Berton Sharp have been some of the most generous and supportive.

It was necessary to consult several archives for the research that went into this book, and I would like to thank the staff at the British Library, the Science Fiction Collections at the University of Liverpool, and the Bill Douglas Centre for the History of Cinema and Popular Culture at the University of Exeter. Some individuals went out of their way to provide assistance and expertise: Andy Sawyer at the Science Fiction Collections and Phil Wickham at the Bill Douglas Centre deserve special thanks. The visits to these archives and the funding for my $\mathrm{PhD}$ thesis came from the Department of English at the University of Exeter, and none of this research would have been possible without that financial support.

Friends and colleagues have constantly sustained this research, and their interest was one of the things that made the project worth pursuing. I am grateful to them all but I would like to single out the following: in its original stages, this work was shaped by the advice of my PhD supervisor Anthony Fothergill, as well as Steve Neale and Tim Armstrong; Jo Gill, Jane Poyner, Brian Edgar and Max Stites read parts of the manuscript and gave honest and accurate criticism; Dan North guided me in my search for difficult-to-source films; finally, this work has benefitted from the long discussions I have enjoyed with Paul Newland.

I will finish by thanking my parents. They have been a constant source of love and strength and to them this book is dedicated. 
Sections of Race, Ethnicity and Nuclear War: Representations of Nuclear Weapons and Post-Apocalyptic Worlds were previously published as journal articles. Part of chapter 3 was first published as 'Beyond Mad Max III: Race, Empire, and Heroism on Post-Apocalyptic Terrain', in Science Fiction Studies 32.2 (July 2005), pp. 301-15. Part of chapter 5 was first published as 'Physics Made Simple: The Image of Nuclear Weapons in the Writing of Langston Hughes', in the Journal of Transatlantic Studies 6.2 (August 2008), pp. 131-41. The editors of those journals have kindly given permission for these articles to be incorporated within chapters of this book, and I would like to thank Arthur B. Evans at Science Fiction Studies and Alan P. Dobson at the Journal of Transatlantic Studies for that permission and for the advice given by their reviewers. 



\section{Introduction}

This study will range across continents and cultural forms and more than six decades, but it is anchored by Arundhati Roy's assertion, used as this book's epigraph, ${ }^{1}$ that nuclear weapons ${ }^{2}$ are white weapons, and that the virtues and vices of white people and nations are condensed in the figure of nuclear weapons. Roy's proposition is explored from a variety of critical positions in Race, Ethnicity and Nuclear War: Representations of Nuclear Weapons and Post-Apocalyptic Worlds, from inside and outside the perception of whiteness: how have nuclear weapons been read as representative of the scientific achievement, military superiority and responsibility of white Europeans and their descendants? How have they also been interpreted as manifestations of the destructivity, racism and recklessness of white civilization? As part of this process, Race, Ethnicity and Nuclear War explores the ways nuclear representations in Anglophone literary, filmic and other cultural texts since 1945 have been pivotal sites for the articulation of racial, ethnic, national and civilizational identities. These texts are a way of making these identities coherent and legible, but the fact they must be produced means they cannot be taken for granted. Some of the nuclear representations studied in this book contest racial, ethnic, national and civilizational identities as meaningful and decisive ways of categorizing human life, and reveal them as insecure and disabling political compartments.

In this study, nuclear representations are defined as depictions of the following subjects: (1) the invention and use of the first atomic bombs; (2) the nuclear weapon testing and stockpiling of the Cold War superpowers; and (3) nuclear war (often referred to as World War Three) and life after such a cataclysm. Nuclear technology has been the subject of narratives of racial and national belonging and exclusion undoubtedly because its emergence (and deployment against Japan) was read by some commentators as an act of genocidal racist violence, and by some as the apex of Western civilization's scientific achievement. These opposing perspectives are interpretative poles that have been central to nuclear representations. By posing white moral and technological superiority against the destructive technology it supposedly invented, cultural producers have cited nuclear weapons as evidence against white Anglo-Saxon supremacism. From this 
point of view, the scientific achievement of splitting the atom does not reveal white superiority; instead, the enormity of nuclear weapons reminds one that the technology first created by the white world imperils the whole Earth.

Through a range of media, from novels to poetry, short stories to film, comics to oratory, the terms that modern European imperialism depended upon - 'civilization', 'race' and 'nation', in particular - often recur in nuclear representations. Some of these representations, emerging when Europe's empires were relinquishing direct control of their colonies, share the uncertainty that beset the colonial powers following the uneven and often violent decolonizing process. The historical congruence of nuclear representations and decolonization intimates the importance of this context to future visions of World War Three: tropes of genocide, technological and scientific modernity, and the (re)population of the planet are relevant to this apocalyptic subgenre of SF as well as being recurrent elements in colonial history. ${ }^{3}$ Several of the nuclear representations discussed reproduce the justifications of the modern imperial project. But an alternative tradition makes these justifications visible and demonstrates their corrosive, lingering presence in contemporary culture through the depiction of nuclear technology and its possible consequences. Significantly, the idea that nuclear weapons are used to buttress a racial order that privileges whiteness - an idea that prohibits non-white peoples from accessing such technology - remains a potent current running from 1945 until the present day.

Having raised this point to emphasize the importance of the themes in this study, I am mindful to repeat that my focus is literary, cultural and filmic texts. I am not seeking to explain how race and ethnicity have structured Cold War history. If I may be excused a brief aside, I do think such moments have occurred. Civil rights and Cold War historians have long understood that US foreign policy had to negotiate the American government's response to domestic systems of racial discrimination, and vice versa. Recently decolonized nations whose populations had been excluded along similar lines by European imperialism followed the narrative of American desegregation closely, and the allegiances of these nations played an important role in the Cold War. When the black student James Meredith was not permitted to join the University of Mississippi in 1962, President Kennedy ordered federal marshals to force his registration through. This took place on 1 October 1962, after a night of fighting between demonstrators and troops. While not universally praised, Kennedy's actions were widely perceived in the international press as evidence of his resolve to oppose racial discrimination. When the Cuban Missile Crisis took place three weeks later, the presidents of Guinea and Ghana denied refuelling 
facilities to Soviet planes flying to the Caribbean. Kennedy aide Arthur Schlesinger directly attributed the African presidents' actions to the intervention in Mississippi. ${ }^{4}$

The subject of this book is not the mechanisms of history. The subject of this book is the way that representations of nuclear weapons and the world after nuclear war postulate meanings that are only fully activated when considered through the lens of race, ethnicity, nationhood and civilization. In many of the texts discussed, a primary consideration is whether the vestigial master narrative of white supremacy, the narrative of racial superiority that underpinned modern European colonization, is being resuscitated. I have in mind Fredric Jameson's expression, 'if interpretation in terms of [...] allegorical master narratives remains a constant temptation, this is because such master narratives have inscribed themselves in the texts as well as in our thinking about them' ${ }^{5}$ For Jameson the interpretative act runs the risk of being an act of hermeneutic bad faith - the risk that the critic finds what they were looking for all along because they gathered up a series of texts whose selection is far from arbitrary, and consequently the reading of said texts confirms the ubiquity of the historical essence with which they were initially ascribed. Yet, as Jameson writes, one should not be too cynical about the act of interpretation. If the critical analysis of a text finds evidence of the historical trends it set out to discover, the success of the interpretation is not in itself a reason to reject the idea that texts allow one to think closely and critically about historical attitudes. The act of interpretation can sometimes be the imposition of a preconceived set of ideas onto a series of texts chosen precisely because they corroborate the hypothesis being tested, but it can also be credible because texts are inscribed by history and by master narratives. As a way of referring to an explanation of the movement of history and its future direction, Jameson's sense of 'master narratives' is worth retaining. My usage here designates the explanation itself, specifically the master narrative of white supremacism that proved so useful to European colonialism and the settlement of North America. How do texts come to be inscribed by master narratives? What justification do I have in reading the master narrative of white supremacism and related narratives of settlement through the literary, cultural and filmic texts analysed here?

In answer to the first question, I acknowledge a debt to the work of Derek Attridge in The Singularity of Literature (2004), and J. M. Coetzee and the Ethics of Reading: Literature in the Event (2004) for his formulation of literature as an event performed by the text and by the reader. This 'symbiotic relationship' ${ }^{\prime}$ is especially important for the making of meaning in SF because of the demands placed on readers to accommodate the estranged 
reality on offer. Attridge's influence can be seen in the approach to literary texts and other media forms adopted in this book: meaning is understood to be produced in the moment when the reader (or viewer, or listener, or both) brings their horizon of experience and expectation to engage with a text. The text sets up the possibility of readings that are brought to life by the mind of the reader in a personal and unrepeatable way. This does not mean that the meaning produced between reader and text is so heterogeneous that it cannot be summarized or encapsulated by the critic. The fabric of a text undoubtedly encourages the production of certain meanings and discourages others. Race, Ethnicity and Nuclear War discusses novels, films, speeches, short stories, poems and popular culture in a manner that reflects this. I have attended to the meaning that is produced between the text and the reader, not least my own experience of this process, while accrediting how texts tend towards some reading experiences and not others. While allowing for the unexpected and unpredicted production of meaning, this study examines how texts set up channels of interpretation for readers to follow and reflects on the productive interpretations that can be made with and against those channels. One of the things commented on, then, is how these texts are inscribed by master narratives of race because of the deliberate intentions of the people producing them, as well as the figures of speech and thought surrounding the cultural producers in everyday life that get reproduced semi-consciously or unknowingly. Because the meaning of a text is made and re-made in its encounter with new readers, the master narrative of white supremacism (and indeed any other master narrative) might be discovered because a reader's experience programmes them to activate such meanings. Different media forms are discussed alongside each other the better to discern shared patterns of representation and where different production, distribution and reception contexts modulate those patterns.

As I stress, while the master narrative of white supremacism provides the interpretative spine of Race, Ethnicity and Nuclear War, exaggerating this framework risks simplifying and flattening the complexity of its articulation and the ways in which it is challenged. If the discussion of nuclear representations in this book was so fixated on the prominent subjects of race, ethnicity, nation and civilization that it excluded other factors determining the content and shape of texts, it would cease to be critical. It is not my intention to reduce down the meaning of these texts so they appear as entries in a public debate about race and nuclear weapons submitted in the category 'cultural contributions'. In highlighting aspects that fit this book's overall narrative, it is vital to appreciate that those features are generated by multiple and sometimes conflicting determinants: generic 
expectations, the precedent of commercially successful texts, the weight of tradition, institutional considerations, material technologies of representation and political concerns quite apart from the master narrative tracked here.

Literary scholar Daniel Cordle observes in States of Suspense: The Nuclear Age, Postmodernism and United States Fiction and Prose (2008) that coming to terms with the repercussions of the nuclear context in cultural texts means addressing some pressing methodological questions: 'Because it is suspense - anticipation of disaster rather than disaster itself - that defines the period, it is important to find ways of engaging with the psychological and cultural consequences of living with nuclear weapons that go beyond the simple delineation of depictions of disaster.' Race, Ethnicity and Nuclear War considers several texts where an engagement with racial politics and the nuclear threat seems to be taking place beyond the level of explicit depiction, where the terms of reference are encoded in narrative, iconography and rhetorical figuration. Where my readings position what Cordle identifies as 'non-specific motifs of [nuclear] anxiety' ${ }^{7}$ within this book's overarching interpretational touchstones, I have endeavoured to provide the contextual evidence (biographical details, historical corroboration) that makes such readings hold weight. In other words, I justify reading these representations as concerned with nuclear technology and race because they are explicit themes, or because additional evidence leads me to make a credible case to theme ${ }^{8}$ said texts in this manner. With this explanation in mind, post-nuclear-war texts such as Samuel R. Delany's novel The Jewels of Aptor (1968) or Lorraine Hansberry's dramatic 'fable' What Use Are Flowers (1962), published after her death, ${ }^{9}$ are not discussed. As interesting as they are, simply because they have been written by African Americans does not mean they are about race or ethnicity.

Various parameters have provided limits to this research. First, the nuclear representations studied here come from the Anglophone world and were created to be understood by English-speaking audiences. While I confer with texts whose original language is not English, and gesture to issues that are germane to the non-Anglophone world, they are not the focus of analysis. Second, the period of nuclear representations under consideration runs from 1945 to around 2001, with the first chapter surveying the period before 1945. In 1945 the United States dropped atomic bombs on the cities of Hiroshima (6 August) and Nagasaki (9 August) in order to force Japan's surrender and avoid an invasion of the Japanese mainland. The year 1945 represents the end of World War Two and the acceleration of hostility between the USA, the USSR and their respective allies in the Cold War proper. Broadly speaking, 2001 is the cut- 
off point for the texts discussed because the terrorist attacks on American soil on 11 September inaugurated a different era of nuclear anxiety. The final chapter in Race, Ethnicity and Nuclear War outlines how the War on Terror relates to the long history of nuclear representations, drawing points of connection and contrast with the Cold War period. Chapter 7 also discusses texts after 2001; in this instance that extension seems appropriate, since many of the writers were responding to India's and Pakistan's nuclear weapon tests in 1998. The full import of those tests, and the diplomatic standoff of which they were a part, required more than three years for writers to formulate and publish their literary responses.

Referring to the USA's response to nuclear weapons, cultural historian Paul Boyer has modelled three 'great cultural cycles, or waves' of 'intense political activism and cultural attention': the first is August 1945 to the early 1950s, the second is the mid-1950s to the Limited Test Ban Treaty of 1963 , and the third starts with Ronald Reagan's election to US President in 1980 and ends in the latter half of the 1980s, when easing of aggression between the USA and USSR made 'nuclear concerns [seem] passé and irrelevant'. ${ }^{10}$ While many of the exemplary and most popular of the nuclear representations discussed here fit into that model, others do not. That should give an idea of the specificity of Boyer's schema - it is designed to capture the peaks of nuclear tension and cultural production, but this study is as interested in capturing the ideas in texts that fall outside the main cycles. ${ }^{11}$

\section{The Field of Scholarship}

Race, Ethnicity and Nuclear War has been nourished by the insights of critical theory, not least postcolonial studies and critical race theory, as well as SF studies, nuclear criticism, and Cold War cultural and literary studies. For this project, two key texts from SF studies have been Paul Brians's Nuclear Holocausts: Atomic War in Fiction, 1895-1984 (1987), and I. F. Clarke's Voices Prophesying War: Future Wars 1763-3749 (2nd edn, 1992). These extensive surveys of the future-war genre touch upon the themes of race, the legacy of imperialism and the history of nuclear representations, and Race, Ethnicity and Nuclear War will develop the connections they identify. This book joins Patricia Kerslake's Science Fiction and Empire (2007), Adilifu Nama's Black Space: Imagining Race in Science Fiction Film (2008), and John Rieder's Colonialism and the Emergence of Science Fiction (2008) in placing a renewed appreciation of race and colonialism in the development of science fiction. It complements these studies: Kerslake and Nama do not focus on nuclear representations, and by starting in 1945, Race, Ethnicity and Nuclear War begins roughly where Rieder's excellent study concludes. I offer an alter- 
native to Rieder's hypothesis that after the 1940s the theme of 'natives being massacred by super-weapons' in American invasion narratives was replaced with the fear of contagion and the surreptitious transposition of human life and inhuman substitutes. ${ }^{12}$ Admittedly, American neocolonialism is different in kind from its European predecessors, but Race, Ethnicity and Nuclear War establishes how superweapons have an ongoing role in speculated conflicts between ethnicities, races and civilizations after 1945. Nuclear weapons, nuclear war and its imagined consequences are narrative devices underscoring the longevity of spectacular military technology in science fiction and its colonial and anticolonial perspectives - which is not to say such representations have not been joined by the invisible invasion motif, and Octavia E. Butler's fiction is discussed later. Patrick B. Sharp's Savage Perils: Racial Frontiers and Nuclear Apocalypse in American Culture (2007) tracks how American apocalyptic visions from the Civil War to 1959 relate to a social Darwinist version of the American frontier as a battle for survival where the (white) emissaries of civilization overcome the less developed forces of savagery. The 1946-1959 nuclear frontier fictions frequently depicted a corrupt civilization destroying itself in a nuclear war, enabling the survivors to rebuild civilization free of moral pollution. In noting the Darwinist and frontier dimensions of post-apocalyptic fictions, Savage Perils extends the insights made by M. Keith Booker in Monsters, Mushroom Clouds, and the Cold War: American Science Fiction and the Roots of Postmodernism, 1946$1964(2001)^{13}$ and other SF scholars. Sharp's position will be returned to in several ways, adding to and finessing his interpretations. Savage Perils hinges on relating the racial interpretation of nuclear weapons back to the master narrative of social Darwinism and the frontier, and while the literary and cultural history assembled in Savage Perils is illuminating, some texts can be read productively for their racial politics outside that context.

In the 1980s and early 1990s analyses of nuclear representations were dominated by the school of nuclear criticism, though this body of scholarship is little known in the twenty-first-century academy. Broadly speaking, nuclear criticism studied the applicability of the human potentiality for nuclear self-destruction to the study of human cultural myths, structures, and artefacts' ${ }^{14}$ It drew on research in SF studies and pressed new (or newly translated) theories of poststructuralism into the service of antinuclear activism. The proliferating concern (culturally and politically) with nuclear apocalypse in the 1980s was, seemingly, a situation that demanded the attention of academics. ${ }^{15}$ One of the most memorable areas of nuclear criticism was analysing the rhetoric used by politicians, strategists and the media. By revealing the paradoxes inherent within that rhetoric, and highlighting the role language played in normalizing the 
nuclear arms race, nuclear criticism sought to contribute meaningfully to the antinuclear movement. ${ }^{16}$ By the early 1990 s the Cold War was winding to a close and the USSR was being dismantled; as a consequence, the risk of World War Three was perceived to be ebbing, the compelling ethical context for nuclear criticism no longer seemed so urgent, and it quickly dwindled as a scholarly pursuit. Nonetheless, the unlikelihood of all-out nuclear war did not erase the perceived danger of nuclear weapons in the hands of terrorists or 'rogue states'. It has been noted that a renewed nuclear criticism might play a role in research into cultural texts and current nuclear anxiety. ${ }^{17}$ The final chapter in Race, Ethnicity and Nuclear War is work of this kind, elucidating how a long history of assumptions surrounding the Third World inform the iconography and rhetoric of twenty-first-century nuclear representations. Nuclear criticism studied nuclear war through several contexts: eschatology, gender, the psychological effect of potentially imminent destruction, the role of knowledge and technology in Western culture, and military and strategic history. In 1995, Ken Cooper's book chapter 'The Whiteness of the Bomb' added race to this list. Self-identifying as white, Cooper writes, 'To put the matter bluntly, the bomb was built by people like me for the protection of people like me'. ${ }^{18}$ Although I try to nuance this position, Race, Ethnicity and Nuclear War returns to the writers Cooper identified, such as Langston Hughes and Ishmael Reed, and extends the connections he made between race, literature and nuclear weapons. To a greater or lesser extent, this book touches on all of nuclear criticism's aspects, and while the tone may be less imperative, at several points I demonstrate the semantic heterogeneousness of cultural texts and the political implications of this - a classic nuclear critical move. The most important feature that distinguishes Race, Ethnicity and Nuclear War from earlier nuclear criticism is that the political implications under discussion are primarily related to racism and postcolonialism, not antinuclear activism.

If nuclear criticism's presence in the humanities is a small blip on the academy's radar, a steady volume of research is being produced in the field of Cold War literary and cultural studies. Roughly beginning in the 1990s and growing in volume in the 2000s, this scholarship built on Paul Boyer's By the Bomb's Early Light: American Thought and Culture at the Dawn of the Atomic Age (1st edn, 1985; 2nd edn, 1994) and Stephen J. Whitfield's The Culture of the Cold War (1991). Whitfield's cultural history charts the political thought of the anticommunist movement and its dissenters from the end of World War Two to the early 1960s; its chapters on cinema and television indicate the usefulness of using those media to study the political sensibilities of the period. Aside from its intelligence, Alan Nadel's Contain- 
ment Culture: American Narratives, Postmodernism, and the Atomic Age (1995) is of interest for forming a bridge between earlier nuclear criticism and later research into the cultural Cold War. Nadel's thesis is that as part of the Cold War the USA tried strictly to delineate the boundaries between 'us' and 'them' in terms of political allegiance, religion, sexuality and in relation to events and the narration of those events (history). Under the pressures of the era (including the nuclear threat), these boundaries collapse or are untenable, creating the conditions for the germination of postmodernism. Retaining the nuclear critics' close attention to the material and rhetorical postures of nuclear defence, Cold War literary and cultural studies seems less interested in the fear of nuclear war and is more attuned to the Cold War of espionage, proxy wars such as the Vietnam War, and the role of culture in campaigns (ideological and institutional) against communism. As a particularly stimulating example of this kind of criticism, Adam Piette's study of literature from the USA and UK, The Literary Cold War, 1945 to Vietnam (2009), does fine work placing writers such as Graham Greene, Vladimir Nabokov and Allen Ginsberg biographically and literarily in the aforementioned contexts. Tony Shaw's books British Cinema and the Cold War (2001) and Hollywood's Cold War (2007) provide thorough case studies which elaborate the extent to which UK and US film production in the period was overdetermined by institutional apparatuses, governmental initiatives, public taste and the profit motive. In Music and Ideology in Cold War Europe (2003), Mark Carroll underlines the Cold War context surrounding classical music in early 1950s Paris: certain types of composition were claimed to signify the greater value of culture produced in the 'free world' compared to the more artistically conservative Soviet regime. Earlier examples of this trend - studying Cold War literature and culture without specific recourse to the nuclear threat include Woody Haut's Pulp Culture: Hardboiled Fiction and the Cold War (1995) and Thomas H. Schaub's American Fiction in the Cold War (1991). The latter interprets the Cold War as a time of ideological readjustment, with literature, literary criticism and liberalism re-orientated as a result of the events of 1939-45. With more space devoted to the nuclear threat's influence on formal technique and subject matter, Edward Brunner's Cold War Poetry (2001) and Bruce McConachie's American Theater in the Culture of the Cold War (2003) are more embedded in the nuclear critical tradition than some of these other works. As these examples attest, academic interest in the Cold War period is enormously high, and Race, Ethnicity and Nuclear War will demonstrate the complex ways that 'homefront' debates over race, ethnicity and nuclear weapons related to the ideological battle being fought against the communist world. 


\section{Constructing 'Race', 'Ethnicity', 'Nation' and 'Civilization' in the Modern Period}

Some clarification of key terms used in this study - race, ethnicity, nation and civilization - will be of use to the reader. In terms of race, theorist Kwame Anthony Appiah has indicated there is a long history of defining collective identities with reference to physical and mental characteristics, going back (at the very least) to the classical Greeks and the ancient Hebrews. ${ }^{19}$ However, the word 'race' did not enter the English language until the sixteenth century, when it carried several meanings: offspring in a line of descent ('the race of Williams'), or a general term of classification ('the human race'), or one's inherited disposition. ${ }^{20}$ In early modern Europe, Christianity was used to explain human difference, but from the eighteenth century onwards the attempt to subdivide humankind into races made common cause with the overarching categorization project of Natural History, with Linnaeus's Systema Naturae (1735) proving seminal in both fields of knowledge. ${ }^{21}$ Some pernicious, recurring assumptions were present in Linnaeus's writings, such as the characterization of Africans as 'Crafty, indolent, negligent'. ${ }^{22}$ Following Linnaeus, scientists and scholars into the nineteenth century demonstrated the superiority of white people in matters of beauty and intelligence, drawing on anthropology, physiognomy, craniometry, craniology and phrenology. ${ }^{23}$ The idea that humans belonged to separate races and that some were better, purer and more intelligent than others hardened into an increasingly circulating scientific 'truth'. In the 1850s Count Arthur de Gobineau hailed the Aryans as the purest and most superior strain of the white North European race; he was absolutely against any intermixture with inferior races, arguing it would lead to civilization's decline. ${ }^{24}$

In 1859 Charles Darwin proposed a theory of human evolution based on natural selection: when a species was better suited to its environment than another because of an inheritable trait, it was more likely to survive, reproduce and therefore pass that trait down to successive generations. Social Darwinists bent Darwin's theory to explain human difference in a way that was racist and hierarchical, and applied these ideas to the management of human populations. ${ }^{25}$ Even Darwin wrote 'the civilised races will almost certainly exterminate and replace $[\ldots]$ the savage races' in a matter of centuries. ${ }^{26}$ In the nineteenth century, as the United States spread across North America and European colonial rule was entrenched around the globe, North American and European race scientists were demonstrating the superiority of the white race. These race scientists, sometimes knowingly and sometimes unconsciously, were doing the ideological work of 
white colonization, justifying white settlement across the world as the inevitable and righteous victory of an intelligent and deserving race against undeveloped and lazy races. ${ }^{27}$ With this in mind, race is not simply the theoretical or empirical extrapolation of biological fact. Race is constructed along the lines of discourse, as detailed by the French philosopher Michel Foucault - sciences produce the phenomenon of race and make it epistemologically credible by generating and confirming hypotheses through selection of evidence. ${ }^{28}$ As Rieder's scholarship has shown, science fiction as a genre emerged as European colonialism reached its apex-and 'powerful, widespread racist ideologies' were invaluable as the explanation and the engine of European colonialism and North American settlement. In complicated ways, science fiction texts deployed race as part of a signifying system delineating the permutations and limitations of human life. ${ }^{29}$

By the last half of the nineteenth century, 'race' referred to subsections of humankind that had inherited characteristics from preceding generations, becoming discrete groups distinguishable by physical appearance and mental capacities. ${ }^{30}$ While I do not agree that humans belong to racial groups ascribed by nature with specific qualities and characteristics, I use the term 'race' in this study because, as a social category, it powerfully structures the way humans relate to themselves and other human beings. As critical race theorist Ian F. Haney López puts it, 'Biological race is an illusion. Social race, however, is not [...] Race has its genesis and maintains its vigorous strength in the realm of social beliefs. ${ }^{31}$

Given the poisonous history surrounding the idea of race, it is unsurprising that official data collection by contemporary state institutions uses the term 'ethnicity'. Scholar Werner Sollors speculates that the rejuvenation of this term was a reaction against Nazi Germany's fetishization of race in the 1930s and 1940s: ethnicity was 'revitalized during World War II, [serving] as a more neutral term than the one in the name of which the National Socialists shaped their genocidal policies' ${ }^{32}$ Ethnicity provides a way to register difference within the compartments of nationhood and biological race. ${ }^{33}$ Ethnicity represents membership of a distinctive group whose identity is not necessarily derived from physiology; rather, it may be defined by language or religion. Race, Ethnicity and Nuclear War takes ethnicity - 'belonging and being perceived by others as belonging to an ethnic group' ${ }^{34}$ - to refer to differences that are intraracial. Undercutting biological determinism's power, 'ethnicity' does not seem to do the same work as 'race' in prescribing the potential or character of a group's members. However, it would be fallacious to suggest that ethnicity is a more mutable category because it is socially agreed upon rather than bequeathed by nature: 
the notion has gained dominance that a 'people' is held together by a subliminal culture of fairy tales, songs, and folk beliefs - the original ethnic ('völkisch') subsoil of the common people's art forms that may culminate in the highest artistic achievements. As a result of this legacy 'ethnicity' as a term for literary study largely evokes the accumulation of cultural bits that demonstrate the original creativity, emotive cohesion, and temporal depth of a particular collectivity. ${ }^{35}$

Ethnicity still interprets humanity as subdivided between discrete groups whose signifying practices are expressive of that group's innate and distinctive cultural being. To take an example Sollors uses, literature is not a window through which eternal essence can be seen; literature makes the shared characteristics of an ethnic group seem automatic and self-evident by supplying the repertoire of imaginative and symbolic structures that intensify (or, at times, even generate) group consciousness'.$^{36}$ This book shares the definition of ethnicity as a marker of collective identity that is not grounded in physiological difference, but it also attends to its instability and the role of cultural production in making and unmaking its coherence.

The distinction between race and ethnicity is an interpretative tool that foregrounds the historical specificity of other key terms. One such term is 'whiteness', which pulls ethnic identities into a racial collective that is homogeneous enough to justify generalizations by the race thinkers who have a stake in its deployment. In the United States, the conglomeration of ethnic groups - perhaps self-identified as Anglo-Saxons, Celtic Irish, Italian and Russian - under the umbrella of racial whiteness made sense to white supremacists keen to identify these groups as capable of assimilation into American civilization. Knitting them together as white and American continued to exclude groups deemed non-white and unable to participate as full citizens in a modern democracy, such as Native Americans, African Americans and Asian Americans. Historian David R. Roediger's The Wages of Whiteness: Race and the Making of the American Working Class (1991) identifies the mid-nineteenth century as a pivotal point in this history. Until the 1830s, black and Irish Americans lived, socialized and worked together, a relationship that decisively shifted as Irish Americans came to 'treasure' their 'whiteness' and deny their affinity with black Americans because that denial would 'entitl[e] them to both political rights and to jobs' ${ }^{37}$ This is one example from a much longer historical narrative, and historians argue it was only during the mid-twentieth century in America's suburbs (with its corollary, the erosion of ethnically distinctive inner-city communities) that whiteness was bound together with maximum cohesion. ${ }^{38}$ 
In his racial history of America's working class, Roediger observes the ethos of capitalism-constructed 'blackness' as belonging to the pre-industrial world:

Increasingly adopting an ethic that attacked holidays, spurned contact with nature, saved time, bridled sexuality, separated work from the rest of life and postponed gratification, profit-minded Englishmen and Americans cast Blacks as their former selves [...] Blackness and whiteness were thus created together. ${ }^{39}$

Novelist Ishmael Reed notes that 'black American' is a multiracial identity whose genealogy stretches back to Europe as strongly as Africa. Reed believes this blanket concept of blackness is inherited from plantation slavery, when, regardless of the race of the father, the offspring of female slaves would be deemed black and therefore the property of the mother's master. The rape of female slaves by male slave-owners was widespread and white fathers would own their interracial children as chattel. ${ }^{40}$ After Emancipation, the percentage of African ancestry that qualified an American as black varied from state to state and across different historical moments. Virginia's 1924 Act to Preserve Racial Integrity adjudged that any African ancestry legally situated that person on the black side of the colour line - commonly known as the 'one-drop rule'.$^{41}$ For Reed, there is a political stake in continued references to a uniform 'blackness': it reciprocates the supposedly homogeneous category of whiteness discussed above. ${ }^{42}$ The presence of 'white', 'black', 'whiteness' and 'blackness' in this book is accompanied with the desire to trace how nuclear representations have been complicit in the political utility of whiteness and blackness.

At first it seems the modern nation state enjoys parameters that allow one to define it without ambiguity, to say ' $\mathrm{X}$ is a nation' and ' $\mathrm{Y}$ is not'. Those parameters might include a government with sovereign command over the civil life of the country's territory, physical limits demarcated by agreed-upon borders, a flag, a national anthem, a football team. With this in place, we can say 'Mexico is a nation' or 'Finland is a nation' and not 'South America is a nation'. Tellingly, my phrasing 'modern nation state' indicates this idea of nationhood belongs most confidently to the modern period. ${ }^{43}$ Further, while my brief list prompts us to recognize the shared features that many nations possess, it is too simple to see the nation as a checklist of tangible points. In 1882 the French thinker Ernest Renan pointed out that traditional markers of national identity are ultimately insufficient to explain the modern nation state: France went on existing without its dynasty, geography is too changeable to be a cause, and neither religion nor language necessarily appears to bind nations together 
(Switzerland has more than one of both). ${ }^{44}$ My position takes its cue from Benedict Anderson's seminal Imagined Communities (rev. edn, 2006), which suggests (in the modern period) the nation exists as an imagined collective. For Anderson, national print media such as novels and newspapers generated the imagination of national community. The experience of their shared consumption produced a sense that the consumer was one of many simultaneous consumers - and that community went under the name of the nation. ${ }^{45}$ Literary scholar Timothy Brennan draws attention to the etymology of nation, coming from the Latin natio and its meanings of 'local community, domicile, family, condition of belonging ${ }^{\prime}{ }^{46}$ indicating the kind of ideological investment that a nation's members make in the national community: 'a deep, [temporally] horizontal comradeship' ${ }^{47}$ The rise of the modern nation state should be placed next to the dawning sensibility articulated by the eighteenth-century German philosopher Johann Gottfried von Herder, for whom the Völkgeist (the spirit of a people) created a distinctive folk culture of which the nation was an expression. ${ }^{48}$ The idea of a nation and a people is projected into the past to stabilize their collective identity in the present, and after Herder, writers periodically pose the nation as organic and automatically emanating from its members. ${ }^{49}$ As with race and ethnicity, nationhood is not passively reflected in film, literature and popular cultural texts; 'texts are [...] productive forces in nationbuilding enterprises', ${ }^{50}$ but it would be erroneous to see the text as the sole constituent of the meaning of nationhood. 'In this world of self-made ethnics and constructed births of nations it is important to keep remembering that rhetoric, texts, and literature are needed to naturalize these processes' while avoiding the temptation to instate language as a constitutive essence 'that would substitute for history, the individual, or the social realm' ${ }^{51}$ There is a political importance to studying the cultural production of racial, ethnic and national identities, but the politics involved borrows its importance from these other contexts. It does not replace or compete with their importance.

Marxist theorists Immanuel Wallerstein and Etienne Balibar conceive of a complex, reciprocal relationship between nationalism and racism, where racism is part of nationalism, it supplements nationalism, and it exceeds nationalism. Racism is an ideological aide to lend national identity authenticity and purity, sometimes going under the guise of 'ancestry' ${ }^{52}$ Racism exceeds the nation state in relation to the inequalities of the world system of capitalism, whereby some geographical areas of production are privileged and 'core' and other areas of the world are disadvantaged and subordinate - 'peripheral'. Racism is sustained by this disparity, expressing and promoting global capitalism's axial division of 
labour: mapping the economic eminence of disparate nations onto a racial bloc of whiteness unified those nations' white populations, the better to lay claim to their shared economic interests. Wallerstein and Balibar reach for this conceptualization to understand why (in their assertion) racism is getting worse. ${ }^{53}$ The thinking about race and nation in Race, Ethnicity and Nuclear War repeatedly attends to these terms' deployment by governments and cultural producers to find a position in the world system of capitalism; for instance, the Indian government's appeal to nationalism in relation to the May 1998 nuclear tests drew attention away from their economic policies, as discussed in chapter 7, and American narratives of post-nuclear-war invasion worked through anxieties about the US economy, examined in chapter 2.

In many of the texts discussed in this book, 'civilization' simultaneously denotes two concepts: first, the achievements of Europe and North America, and second, the history of human development, in whose name the West speaks, since its endeavours are self-promoted as exemplary. The capitalist democracies of North America and Western Europe identify themselves as existing on a continuum stretching back to Ancient Greece, a continuum constituting the journey of scientific learning towards refinement and perfection. In polemical terms, the film and literary scholars Ella Shohat and Robert Stam describe this as a journey from 'Plato-to-NATO': 'Eurocentric discourse projects a linear historical trajectory leading from classical Greece (constructed as "pure," "Western," and "democratic") to imperial Rome and then to the metropolitan capitals of Europe and the US. ${ }^{.54}$ The term appears to be first used in the eighteenth century and is built onto the root 'civilize', which originates in the early seventeenth century. This idea of an advanced stage in the development of human society should be set in the context of the contemporaneous making of the modern world: 'civilization' legitimized why non-Europeans profited from being exposed to European culture and this history will become apparent as we examine how the word operates in the nuclear representations that follow.

\section{The Structure of the Book}

This study outlines two broad ways in which nuclear weapons have been seen as white: first, because the weapons themselves symbolize the achievements, atrocities and attitudes of European and American modernity, and second, because the post-nuclear-war future that such weapons could make possible is deemed to reproduce a (European) colonial or (American) frontier dynamic in which white Europeans and their descen- 
dents defend and enlarge their societies at the expense of non-white peoples. Roughly speaking, the first section of this book discusses depictions of the world after nuclear war, where the latter trope dominates; in the second section, which focuses more on the invention of nuclear weapons, arms stockpiling and deterrence, the former issue of which race, ethnicity or nation is represented by nuclear weapons comes to the fore.

The first chapter, 'Race, War and Apocalypse before 1945', details premonitions since the late nineteenth century of an apocalyptic race war fought with the newest, most destructive technology. Where the perpetrators, victims and survivors of nuclear war are racially or ethnically marked in cultural texts, those markings often reflect perceived hierarchies of mental, moral and physiological difference. Historian John W. Dower's comments on World War Two in the Pacific are relevant here:

The war words and race words which so dominated the propaganda of Japan's white enemies - the core imagery of apes, lesser men, primitives, children, madmen, and beings who possessed special powers as well - have a pedigree in Western thought that can be traced back to Aristotle, and were conspicuous in the earliest encounters of Europeans with the black peoples of Africa and the Indians of the Western Hemisphere. The Japanese, so 'unique' in the rhetoric of World War Two, were actually saddled with racial stereotypes that Europeans and Americans had applied to nonwhites for centuries. ${ }^{55}$

The dehumanization of the Japanese shares similarities with the demonization of Jews in European culture. In its German nationalist interpretation, anti-Semitism ensured Germany's racial hygiene in a war waged in the name of Heaven. Leading up to 1945, a torrent of future-war fiction was published in which victory went to the people most prepared for conflict and able to develop the most sophisticated new weapons (these narratives typically imagined future wars as fought between fundamentally incompatible ethnic groups). In the American permutation of this transnational literary genre, conflicts between Asian nations and the United States dominated. The incompatibility of Japanese and white American culture was interpreted by Allied officers and media during World War Two as follows: either we wipe out their civilization or they wipe out ours. The racism vocalized by the policy drivers of the USA's Pacific war is one reason several cultural texts in this book have seen the dropping of atomic bombs on Japanese civilians as a racially motivated attack, despite the historical debate over the decision.

Chapter 2 addresses American novels and short stories where the polarity of the frontier is reversed, and the United States is pushed back or 
recolonized after a nuclear war. In these texts, the post-nuclear-war frontier does not constitute the leading edge of civilization projecting west from white settlers on the American East Coast and from Europe before that. Instead, white American society survives uncertainly and is blinking out of existence. William Tenn's short story 'Eastward Ho!' (1958) is a satire on the colonization of North America: whites are abused for being savages, unable to hold their drink or use firearms responsibly, and Native Americans scorn them. Native Americans have the material power to back up their racial chauvinism and are too powerful to be held to account by the United States when they break treaties intended to respect white territory. In witty, engaging ways, Tenn confounds the assumed righteousness of America's settlement. Chapter 2 also discusses Michael Swanwick's short story 'The Feast of Saint Janis' (1980) and Whitley Strieber and James W. Kunetka's novel Warday (1984), which envisage a future where white Americans are technologically and financially bankrupt, sliding into totalitarianism and pagan ritual, and dependent upon the charity of Japan, Europe and Africa. I understand these texts as responses to the underperformance of the American economy compared to countries like West Germany and Japan. This is dramatized in the form of the unfair economic conditions imposed on the nuclear-devastated USA. In 'Feast' and Warday the social consequences of economic decline are crime and social breakdown, which leads to authoritarian policing and urban segregation in America's cities. Yet, rather than see social breakdown and authoritarianism as a product of unregulated capitalism, totalitarianism is projected onto the foreigners who operate as symbolic interlopers in the USA's financial sovereignty.

A recurrent motif of post-nuclear-war fiction is the use of Australia and the South Pacific as the location of human survivors. Chapter 3 traces the cultural history that has given this motif its potency. On the level of visual representation, there are profound continuities between the colonial past, speculated post-apocalyptic futures and certain (supposedly) barren and featureless geographical areas of the world, of which the Australian desert is a paradigmatic example. The adhesive connecting all three cultural spaces is the notion of the 'soft place', taken from Neil Gaiman's The Sandman series of comics. This term refers to the way that post-apocalyptic space and precolonized territory are traditionally visualized as a flat, unmapped, bare canvas, on which heroic exploits can be acted out. Chapter 3 analyses the film Mad Max Beyond Thunderdome (1985), arguing that its representation of the Outback is evidence that narratives of colonial settlement continue to inform late-twentieth-century Western culture, although the film's complicity with imperial assumptions about race, space 
and the civilizing mission is far from simple and coexists with the demands of concluding an action-adventure film trilogy.

The fourth chapter comments on several American films and novels from the 1950s, early 1960s and the 1980s, focusing on a major theme structuring interracial relations in the post-nuclear-war world: who is to have sex, and with whom? This is a crucial issue because the reproduction of the survivors will determine who will repopulate the United States (in some instances, the world). The narratives dramatize the conflict that ensues when some of the characters disagree with the racial ingredients out of which the Americans of the future will emerge. This chapter emphasizes the decisions made by survivors in choosing a mate for procreation; it uses Werner Sollors's model of how American identities are held in tension between descent and consent relations to discuss the strategies used to explain characters' decisions to reproduce 'with their own kind' or not.

Chapter 5, 'White Rain and the Black Atlantic', explores the nuclear representations of the African diaspora and asks how cultural producers from the black Atlantic have seen nuclear weapons as a symbol of the destructive tendencies of a modernity claimed by and for its white citizens. The title comes from Caribbean poet Olive Senior's reworking of radioactive black rain into 'white rain' in the poem 'rain' (1985), signifying the significance of racial whiteness influencing the decision to drop atomic bombs on Japanese citizens in 1945. Gilroy has suggested that black Atlantic writers, thinkers and performers have historically been characterized as within modernity but denied full access to it. The efficacy of black Atlantic critiques of nuclear weapons is that they bear the cultural memory of the exertion of terror and technology in the interests of white privilege.

'Race and the Manhattan Project', the sixth chapter, also analyses texts that consider whether the development of nuclear weapons buttresses racial hierarchies. This chapter explores a subgenre of the thriller novel that investigates accidents or murders at the military base at Los Alamos, New Mexico, where the first atomic bombs were built. Dexter Masters's The Accident (1955), Martin Cruz Smith's Stallion Gate (1986) and Joseph Kanon's Los Alamos (1997) link the potential genocide represented by the birth of atomic weapons to the extermination of Jews in Europe. All three novels profess a tension between the multinational contributors to America's atomic bomb programme and agents within the American state that seek to purge the Manhattan Project of its non-white or un-American elements. All three novels discuss the Holocaust as a barbaric act but warn that America's atomic bombs are justified with the same rhetoric that the Nazis used: the enemies of civilization must be exterminated absolutely to 
preserve our way of life. However, as the Holocaust recedes further into history, this subgenre of the historical thriller increasingly relies on racial difference to explain the physical appearance of characters and their function in the plot.

The seventh chapter concentrates on Ruchir Joshi's novel The Last JetEngine Laugh (2001) and its emergence in Indian history when nuclear weapons were a bold and highly visible way for India's rightwing BJP government to signify national power and independence from other nations. This is the paradox of India's late 1990s nuclear nationalism: the successful achievement of Indian modernity and the realization of its politically autonomous nationhood are projected through the act of emulating existing nuclear powers, some of which were the former European empires from which Hindu nationalism sought to distance India. While the focus is on Joshi's novel, and its conjectured future wars between India and Pakistan (Mumbai is atomized during one nuclear exchange), several novelists originating from South Asia have drawn attention to the antimony of India's nuclear nationalism, and this chapter draws on the novels and essays of Romesh Gunesekera, Arundhati Roy and Vikram Chandra in addition to Joshi's novel. For these writers, the acquisition of weapons previously seen as white promotes massive conflict and interethnic violence. The Indian nationalism that was successful at the electoral polls was Hindu nationalism, and its programme of self-renewal was rooted in a tradition of paramilitary activity, the persecution of non-Hindu Indians and the demonization of Pakistan as an unstable aggressor. The Last JetEngine Laugh yokes together the political rise of Hindu nationalism and Indian military belligerence, and reflects upon the contradictions of measuring cultural progress by the adoption of the former oppressor's weaponry.

The final chapter of this study constructs a historical narrative from 1945 to the early twenty-first century, tracing the fear that the instability of the Third World will lead to a future nuclear catastrophe. That catastrophe is figured in two ways, either that World War Three will begin as a result of military manoeuvring in the Third World or 'rogue states' will enable terrorists to use nuclear weapons against a Western city. Throughout the second half of the twentieth century, fiction writers and members of the scientific community argued that you stop a Third World War by preventing nuclear weapons falling into the hands of Third World nations. Chapter eight analyses how the language and imagery used assumes that nuclear technology is too complex to be used by formerly colonized nations, reproducing the notions of cultural sophistication embedded in the master narrative of white supremacism. The arrogation of representing 
civilization that took place during modern European imperialism and the settlement of North America is worth attending to in the history of nuclear representations since 1945 because it continues to influence the language used in the War on Terror.

\section{Notes}

1. Arundhati Roy, The Algebra of Infinite Justice, Flamingo, London (2002), p. 11.

2. The historical use of the terms 'atomic' and 'nuclear' is complex, and they refer to the development in physics of atomic fission and fusion processes. Historically, until the mid-to-late 1950s 'atomic' is the predominant term for weapons utilizing this technology, after which 'nuclear' is generally preferred. Much more powerful weapons were being developed in the early 1950s; the first hydrogen bomb was tested on 1 November 1952, using nuclear fusion rather than fission. See Spencer R. Weart, Nuclear Fear: A History of Images, Harvard University Press, Cambridge, MA (1988), p. 155. I use 'nuclear weapons' to refer to either those more powerful hydrogen weapons or to nuclear and atomic weapons, in line with contemporary usage in which 'nuclear' is a catch-all term. I reserve the term 'atomic' specifically for the earlier stage of technology. The evolution of terminology from 'atomic' to 'nuclear' in the 1950s took place unevenly and often irrespective of the actual technology referred to. Certain cultural texts featuring in this book use 'atomic' and 'nuclear' interchangeably and I have tried to reflect the language used by the texts themselves.

3. John Rieder, Colonialism and the Emergence of Science Fiction, Wesleyan University Press, Middletown, CT (2008), p. 124.

4. Mary L. Dudziak, Cold War Civil Rights: Race and the Image of American Democracy, Princeton University Press, Princeton (2000), pp. 163-65; Brenda Gayle Plummer, 'Castro in Harlem: A Cold War Watershed', in Allen Hunter (ed.), Rethinking the Cold War, Temple University Press, Philadelphia (1998), p. 148. Guinea and Senegal are recorded as the two African nations in question in Robert F. Kennedy, 13 Days: The Cuban Missile Crisis, Pan, London (1969), p. 120.

5. Fredric Jameson, The Political Unconscious: Narrative as a Socially Symbolic Act, Methuen, London (1981), p. 19.

6. Patricia Kerslake, Science Fiction and Empire, Liverpool University Press, Liverpool (2007), p. 134.

7. Daniel Cordle, States of Suspense: The Nuclear Age, Postmodernism and United States Fiction and Prose, Manchester University Press, Manchester (2008), p. 2.

8. Here I use the verb 'to theme' in the sense of 'to identify a theme in', following the example of Werner Sollors, Neither Black nor White Yet Both: Thematic Explorations of Interracial Literature, Harvard University Press, Cambridge, MA (1999).

9. Bruce McConachie, American Theater in the Culture of the Cold War, University of Iowa City, Iowa City (2003), pp. 281-82. 
10. Paul Boyer, By the Bomb's Early Light: American Thought and Culture at the Dawn of the Atomic Age (2nd edn), University of North Carolina Press, Chapel Hill (1994), pp. x-xi.

11. The 'peaks and troughs' version of nuclear representations is disputed, on somewhat different grounds, in Jerome F. Shapiro, Atomic Bomb Cinema, Routledge, New York (2002).

12. Rieder, Colonialism and the Emergence of Science Fiction, pp. 148, 154.

13. M. Keith Booker, Monsters, Mushroom Clouds, and the Cold War: American Science Fiction and the Roots of Postmodernism, 1946-1964, Greenwood, Westport, CT (2001), pp. 65, 67.

14. William J. Scheick, 'Nuclear Criticism: An Introduction', PLL: Papers on Language $\theta$ Literature, 26.1 (Winter 1990), p. 4.

15. See J. Fisher Solomon, Discourse and Reference in the Nuclear Age, University of Oklahoma Press, Norman, OK (1988).

16. Daniel L. Zins, 'Exploding the Canon: Nuclear Criticism in the English Department', PLL: Papers on Language $\theta$ Literature, 26.1 (Winter 1990), p. 36.

17. Daniel Cordle, 'Cultures of Terror: Nuclear Criticism during and since the Cold War', Literature Compass, 3.6 (2006), available at http://0-www3.interscience.wiley.com.lib.exeter.ac.uk/cgi-bin/fulltext/118578161/HTMLSTART (last accessed July 2010); Paul Williams, 'Nuclear Criticism', in Mark Bould, Andrew M. Butler, Adam Roberts and Sherryl Vint (eds), The Routledge Companion to Science Fiction, Routledge, Abingdon (2009).

18. Ken Cooper, 'The Whiteness of the Bomb', in Richard Dellamora (ed.), Postmodern Apocalypse: Theory and Cultural Practice at the End, University of Pennsylvania Press, Philadelphia (1995), p. 81.

19. Kwame Anthony Appiah, 'Race', in Frank Lentricchia and Thomas McLaughlin (eds), Critical Terms for Literary Study (2nd edn), The University of Chicago Press, Chicago (1995), pp. 274-75.

20. Raymond Williams, Keywords: A Vocabulary of Culture and Society (new edn), Fontana Press, London (1988), p. 248; Appiah, 'Race', p. 279. See also Sollors, Neither Black nor White Yet Both, p. 92, and Werner Sollors, 'Foreword: Theories of American Ethnicity', in idem (ed.), Theories of Ethnicity: A Classical Reader, New York University Press, New York (1996), p. xxix, for further discussion of the etymology.

21. Richard Dyer, White, Routledge, London (1997), pp. 22-23.

22. Winthrop D. Jordan, White over Black: American Attitudes towards the Negro, 1550-1812, University of North Carolina Press, Chapel Hill (1968), p. 221.

23. Jordan, White over Black, pp. 499-501; George L. Mosse, Towards the Final Solution: A History of European Racism, Dent, London (1978), pp. 14-15; Brian Wallis, 'Black Bodies, White Science: Louis Agassiz's Slave Daguerreotypes', American Art, 9.2 (Summer 1995), pp. 38-61; Stephen Jay Gould, The Mismeasure of Man (rev. edn), Penguin, Harmondsworth (1997), pp. 67, 90-91, 116; Melissa Percival, The Appearance of Character: Physiognomy and Facial Expression in Eighteenth-Century France, Maney, London (1999), pp. 1, 20, 28, 159; Sollors, Neither Black nor White Yet Both, p. 62. As outlined in Gould, The Mismeasure of Man, p. 70, the categorization of race was not unanimously accepted.

24. Robert A. Nye, The Origins of Crowd Psychology: Gustave LeBon and the Crisis 
of Mass Democracy in the Third Republic, Sage, London (1975), pp. 42-43. Hugh A. MacDougall, Racial Myth in English History, Harvest House, Montreal (1982), records how the English argued for their superior place among the descendants of Germanic peoples.

25. Gould, The Mismeasure of Man, p. 142.

26. Quoted in Rieder, Colonialism and the Emergence of Science Fiction, p. 110.

27. Williams, Keywords, p. 249.

28. Paul Gilroy, Against Race: Imagining Political Culture beyond the Color Line, Harvard University Press, Cambridge, MA (2000). See also Gould, The Mismeasure of Man.

29. Rieder, Colonialism and the Emergence of Science Fiction, pp. 97-98.

30. Sollors, Neither Black nor White Yet Both, p. 101.

31. Ian F. Haney López, 'The Social Construction of Race' (2000), in Julie Rivkin and Michael Ryan (eds), Literary Theory: An Anthology (2nd edn), Blackwell, Malden, MA (2004), p. 972.

32. Werner Sollors, 'Ethnicity', in Frank Lentricchia and Thomas McLaughlin (eds), Critical Terms for Literary Study (2nd edn), University of Chicago Press, Chicago (1995), p. 289; Etienne Balibar and Immanuel Wallerstein, Race, Nation, Class: Ambiguous Identities (1988), transl. Chris Turner, Verso, London (1991), p. 10.

33. To give some idea of the complexity of these terms, ethnic identities can be subdivided by race and racial compartments can be subdivided by ethnicity. See Sollors, 'Foreword: Theories of American Ethnicity', pp. xxx-xxxv.

34. Werner Sollors, 'Introduction: The Invention of Ethnicity', in idem (ed.), The Invention of Ethnicity, Oxford University Press, New York (1989), p. xiii.

35. Sollors, 'Ethnicity', p. 290.

36. Sollors, 'Ethnicity', p. 303.

37. David R. Roediger, The Wages of Whiteness: Race and the Making of the American Working Class, Verso, London (1991), pp. 134-40.

38. John Preston, 'Protect and Survive: "Whiteness" and the Middle-Class Family in Civil Defence Pedagogies', Journal of Education Policy, 23.5 (Sept. 2008), p. 472.

39. Roediger, The Wages of Whiteness, p. 95.

40. Ishmael Reed, Shawn Wong, Bob Callaghan et al., 'Is Ethnicity Obsolete?', in Werner Sollors (ed.), The Invention of Ethnicity, Oxford University Press, New York (1989), p. 228.

41. Sollors, Neither Black nor White Yet Both, pp. 406-407.

42. Reed, Wong, Callaghan et al., 'Is Ethnicity Obsolete?', p. 228.

43. Benedict Anderson, Imagined Communities (rev. edn), Verso, London (2006), p. 7; Hans Kohn, The Idea of Nationalism: A Study in Its Origins and Background, Macmillan, New York (1946), p. 3.

44. Ernest Renan, 'What Is a Nation?' (1882), transl. Martin Thom, in Homi K. Bhabha (ed.), Nation and Narration, Routledge, London (1990).

45. Anderson, Imagined Communities, pp. 34-36. See also Henri Lefebvre, The Production of Space (1974), transl. Donald Nicholson-Smith, Blackwell, Oxford (1991), pp. 111, 231, 245. 
46. Timothy Brennan, 'The National Longing for Form', in Homi K. Bhabha (ed.), Nation and Narration, Routledge, London (1990), p. 45.

47. Anderson, Imagined Communities, p. 7.

48. Appiah, 'Race', p. 284; Brennan, 'The National Longing for Form', p. 53; Kohn, The Idea of Nationalism, p. 4.

49. Balibar and Wallerstein, Race, Nation, Class, p. 10.

50. Anderson, Imagined Communities, p. xv.

51. Sollors, 'Introduction: The Invention of Ethnicity', p. xx.

52. Balibar and Wallerstein, Race, Nation, Class, pp. 80-81, 57-60.

53. Balibar and Wallerstein, Race, Nation, Class, pp. 80-81, 9.

54. Ella Shohat and Robert Stam, Unthinking Eurocentrism: Multiculturalism and the Media, Routledge, London (1994), pp. 2, 14.

55. John W. Dower, War without Mercy: Race and Power in the Pacific War (1986), Pantheon, New York (1993), p. 10. 



\section{Race, War and Apocalypse before 1945}

The idea that antagonism between races might be expressed in a future genocidal war leaving some races extinct and others to inherit the Earth had three main permutations in the late modern period. These spheres of cultural, political and military activity are not as divisible as this chapter's sections indicate, and relevant points of contact will be discernable. The first section outlines the myths of racial destiny generated from the late nineteenth to the mid-twentieth century, most centrally the Aryan myth of eradicating Judaism that would inform the policies of Nazi Germany. The second section surveys (primarily Anglophone) future-war fiction of the same period, which imagined interracial and interethnic conflicts fought with weapons so powerful they would decisively determine the outcome of wars. The final section looks at the racial and exterminatory dimensions of early aerial warfare, concluding with the rhetoric of interracial competition between Japan and America before and during World War Two, and the contemporaneous perception that another monumental war would be required to secure the rule of whites on the Asian continent.

\section{War in Heaven}

As outlined in the introduction, the propagation of Darwin's theory of evolution in the nineteenth century was co-opted to explain human development and racial difference. Social Darwinism provided a methodology and an imperative for race thinkers to argue for measures necessary to preserve the integrity of their respective races. This was deeply implicated in the colonial process, whereby the subjugation of non-white peoples could be buttressed by the scientific argument that those races were inferior deviations from white people. Holding up the superiority of the white race subjected it to renewed scrutiny, and that scrutiny turned to anxiety when the threat of degeneration within white European civilization became a clarion call for advocates of racial purification. The social and cultural historian Daniel Pick puts it succinctly:

degeneration in the second half of the nineteenth century served not only to characterise other races (for instance in the view that other 
races had degenerated from the ideal physique of the white races), but also to pose a vision of internal dangers and crises within Europe. Crime, suicide, alcoholism and prostitution were understood as 'social pathologies' endangering the European races, constituting a degenerative process within them.

Evolutionary theory and racial anthropology were imbricated with an imperialistic insistence on the racial superiority of the world's colonisers over the colonised, but they also reflected back on European society in deeply unsettling ways. ${ }^{1}$

Max Nordau's 1892 book Degeneration offered the aetiological observation that European civilization was jeopardized by the psychological 'fatigue' brought on by the pace and upheavals of modern life: 'steam and electricity have turned the customs of life of every member of the civilized nations upside down'. ${ }^{2}$ The best-selling pamphlet 'The Decline and Fall of the British Empire' (1905) identified 'the prevalence of Town over Country life' as the most poisonous factor in the specific deterioration of the British. ${ }^{3}$ The eminent English scientist Sir Francis Galton wrote in 1903 that the English were 'excellent leaders of the people of the lower races', but he posed the question 'Are We Degenerating?' ${ }^{4}$ Perturbed by Britain's sluggishness in overcoming the Boers in South Africa and the poor physical condition of the volunteers, Arnold White argued this 'cult of infirmity' would have fatal consequences, and in his book Efficiency and Empire (1901) White referred to the 'downfall of the Anglo-Saxon' (specifically British imperial power). Unless the 'stamina of the people' is revitalized, Britain must face the 'loss of an Imperial position acquired by the healthy': 'The Empire will not be maintained by a nation of out-patients. ${ }^{5}$

In order to preserve the quality of Britain's biological stock, Galton was keen to encourage families to record their hereditary characteristics for the purpose of a grassroots eugenic programme. Galton's ultimate goal was that, in choosing a spouse, individuals and families would be driven (for the national good) to choose appropriate biological matches to perpetuate desirable and healthy hereditary features. By preventing reproduction within marriage for those whose nature made them unsavoury as progenitors Galton envisaged a future of racial hygiene in which social proscription would coerce humans to breed with their appropriate counterpart - or, indeed, not at all. Karl Pearson, a follower of Galton, expounded upon his hero's eugenic ideas in Francis Galton, 1822-1922: A Centenary Appreciation (1922), which exhorted the British people to institutionalize the social intolerance towards certain people reproducing that Galton had in mind: 
How are we to bring home to the sound majority of the people the greatness of the burden which that [least fit] minority inflicts upon it! The one blind man with twenty blind descendants; the two deafmutes with forty or more additional deaf-mutes proceeding from them, the insane stirp [hereditary stock] extending its family curse over five generations; the unmarried mentally defective woman whose pedigree shows upwards of a hundred criminals and mental defectives deriving their life from her! ${ }^{6}$

Galton designed two family albums in 1884 to standardize the recording of biological history: Record of Family Faculties and The Life History Album. Galton wanted to accumulate 'a vast colloquial resource' for scientific knowledge, and he offered British families the chance to win $£ 500$ for the best family records submitted by 15 May 1884. Galton's ideas were readily received in the United States, and in the early twentieth century thousands of families submitted their 'Record of Family Traits' to eugenicists for analysis; across fairs in the Midwest, Americans competed in 'fitter family contests' ${ }^{7}$ The family record albums and the 'fitter family contests' illustrate the popular base for these ideas and they also existed at the highest levels of political power. American President Theodore Roosevelt was friends with leading race theorist Madison Grant, author of The Passing of the Great Race (1916), which warned of the threat posed to white Nordic racial stock. Within the community of American eugenic thought that threat came from several directions, such as the Slavic and Latin peoples of Europe as well as Asians. Roosevelt was worried about white stock being flooded by Asian 'blood' and saw America's strategic interests in the Pacific as an advanced outpost of the white race. ${ }^{8}$

The intellectual inclination shared by Galton and other Anglophone eugenicists, of purifying compromised white racial stock to facilitate white rule in the colonies (and internally in the case of the United States), coexisted with even more pernicious programmes for racial cleansing. George L. Mosse's Towards the Final Solution: A History of European Racism (1978) tracks how European racism informed the Nazi party's ideas of an Aryan master race and the magnification of anti-Semitism into genocide. The overlap between race, nation and civilization was evident: in the late nineteenth century, theorists of German identity conflated the national space of Germany with the people known as Aryans and attributed to them a mystical mission against the Jews. Madame Blavatsky's spiritual scheme of Theosophy, based on Indian religions, had wide appeal for those who wanted to discover what the 'race-soul' was. In the German nationalist context, her ideas were shaped into the idea that the German Völk (people) had a privileged place in God's spiritual hierarchy. Put crudely, this was 
because Germans had a natural affinity with the pure, sublime landscape of Germany: race thinkers posited a direct alignment of racially superior Völk and 'the cosmos' through Germany's divine alpine environment. Mosse identifies these ideas in Guido von List's German Mythological Landscape Pictures (1891) and Julius Langbehn's Rembrandt as Educator (1890); as well as being spiritually superior, Langbehn believed in Aryan physiological eminence, as supposedly demonstrated by the racial sciences. Houston Stewart Chamberlain's Foundations of the Nineteenth Century (1899) also fused the racial sciences with Christianity and mysticism. Chamberlain proclaimed the Aryans as the master race on the basis of anthropology and craniometry, proceeding to argue that Christ had 'an Aryan soul' and that Germans were the custodians of a Christian spirituality which made them 'honest, loyal, and industrious'.

Anti-Semitism drew on the explanatory power of this alignment of race, mysticism and landscape: 'the Aryans were set in the German forest, and the Jews in the desert, which expressed their rootlessness and the barrenness of their souls'. In Chamberlain's view, conflict between Germans and Jews expressed a Manichean battle between Christian good and Satanic evil. The future of Christian civilization was at stake: 'The outcome of the battle between Aryans and Jews would decide whether the base Jewish spirit would triumph over the Aryan soul and drag the world down with it [...] Racial mysticism posited a race war - a fight to the finish between two principles of life. ${ }^{10}$ Several figures in the early twentieth century - such as Alfred Schuler, the 'cosmic philosophers' of Munich and the Viennese newspaper owner Jörg Lanz - continued to equate Aryans with a mystical human life-force. Lanz advocated the extermination of the Aryan's enemies, whom he called 'ape-men' and 'dark people of inferior race'. ${ }^{11}$ Hitler saw Schuler lecture, and the accumulation of these racist ideologies was apotheosized in the racist policies of Nazi Germany.

In staking Aryan racial superiority to spiritual exceptionalism, the importance of destroying non-Aryans seemed evident: humanity's connection to higher forces would be lost if the Aryan conduit to either the Christian God or an ethereal life-force was broken. European Jewry became the main victims of this mystic race thinking, but 'dark people of inferior race' were similarly constructed as opponents of the Aryans, and the destruction of both was promoted. The intonation of this racism and anti-Semitism was specifically German nationalist but it was part of a global structure of feeling in which white European empires and the United States believed they were the vanguard of Christian civilization. In securing that civilization, non-white peoples may be eradicated either by accident or 
design. Future-war fiction provided an arena in prose for writers to dream of realizing that process with new technology.

\section{Future-War Fiction}

One can discern the contours of twentieth-century warfare in the American Civil War (1861-65) and the Franco-Prussian War (1870-71), and the modernity of these conflicts was commented on at the time. In the American Civil War, the devastating use of automatic weapons came into relief, as did the potential scale of modern conflict. For the first time, entire populations engaged in a 'new situation of total war' ${ }^{12}$ One of the most noted aspects of Prussia's defeat of France was the speed with which the French were overcome: the Prussian use of trains intimated that the ability to transport troops, arms and materiel as quickly as possible gave armies a decisive advantage over their enemies. ${ }^{13}$ Partly as a response to these conflicts, the late nineteenth century saw a boom in prose speculation about future military conflict that lasted into the twentieth century. Future-war scholar I. F. Clarke hypothesizes that this growth was due to new developments in scientific discovery and military technology, uncertainties over the balance of power in Europe and the commercial opportunity for publishers to satisfy a growing popular readership built on expanding literacy levels. Many of these future-war stories were written by military experts who saw the genre as a way to communicate quickly their ideas about national defence. ${ }^{14}$

The remarkable success of Sir George Tomkyns Chesney's 'The Battle of Dorking', originally published in May 1871 in Blackwood's Magazine, 'established the pattern for a predictive epic on the victory or defeat of a nation-species in the international struggle to survive'. Chesney's futurewar narrative is narrated from a point in the future looking back on a successful German invasion of Britain. Chesney's prediction of defeat was made so readers in 1871 might take steps to prevent it ever happening. This is crucial to the genre paradigm at this historical moment, where readers are urged to take necessary measures to pre-empt the speculative scenario. Those measures might entail remaining alert to the danger posed by certain nations or racial groups, or asking readers to support the modernization of national defence. 'The Battle of Dorking' stressed the importance of deploying new technology on the battlefield. In Chesney's worldview, the army with the most technologically sophisticated equipment will be the winner in a modern war, and his story attributed Germany's triumph to the speed with which they move their troops, and their new 'fatal engines', which sink the British fleet. ${ }^{15}$ 
'The Battle of Dorking' set the template for a genre that spread across North America and Europe, using the spectre of defeat in a future war to warn the addressed populace that action in the present is required to avoid national humiliation. Roughly speaking, Clarke suggests that between 1870 and 1890, future-war fiction was used by writers to critique their own military and prompt its reform. In this period, defeat resulted from a single battle or war. Between 1890 and 1914, texts in the genre addressed their national community with self-aggrandizing visions foreshadowing their conquest of the world. ${ }^{16}$ These stories interlocked with the fears about degeneration that Nordau and his peers raised; the play 'The Englishman's Home', a box-office hit in 1909, featured the invasion of Britain by soldiers from 'Nearland', and the English prove too morally and physically weak to resist. William Le Queux's politically reactionary novel The Invasion of 1910 (1906) even attributed the UK's national malaise to the replacement of aristocratic rule by a government responding to the popular will. ${ }^{17}$ As Rieder points out, the genre was coherent and recognizable enough to support a P. G. Wodehouse parody, The Swoop!: or, How Clarence Saved England (1909). ${ }^{18}$

Despite Clarke's assertion that after the 1880s 'the United States did not have any major external enemy to serve as the focus for future war stories', ${ }^{19}$ there do appear to be certain repeated enemies, such as the British. Americans war against the UK in Samuel Rockwell Reed's The War of 1886, between the United States and Great Britain (1882), Samuel Barton's The Battle of the Swash; and The Capture of Canada (1888) and Henry Grattan Donnelly's The Stricken Nation (1890; written using the pseudonym 'Stochastic'). Fitting the future-war model established by 'The Battle of Dorking', in Stricken Nation the British enemy brings the USA's inadequate defences along the Great Lakes into relief for the American reader. Donnelly does not challenge America and England's shared membership of 'the Anglo-Saxon race' in his novel, but their ethnic rivalry appears intractable: the English cannot suppress their 'traditional envy and hatred ${ }^{20}$ towards the United States. In addition to the British, America's fictional invaders are repeatedly Asian in this period. They are represented as a more malicious enemy because their antipathy to white America does originate in racial difference. Anxiety about the dangers posed by Asian immigration was heightened by the sensationalist reporting of the US press, which stressed interracial incompatibility and aggressive Asian expansionism. The fear and often violence that Americans of Asian descent were subjected to occurred alongside their demonization as a 'Yellow Peril'. In 1882, the USA passed the Chinese Exclusion Act, which banned immigrant labour and stayed in place until 1943. Atwell Whitney's Almond-Eyed: 
A Story of the Day (1878) commenced an American literary tradition depicting the nation subverted from within by Chinese immigrants acting as fifth columnists: in Almond-Eyed, sheer weight of numbers makes the Chinese threatening. Pierton W. Dooner's Last Days of the Republic (1880) follows the same pattern, imagining the Chinese as cunning, avaricious and swarming over the United States until the last bastion of white resistance is eradicated. ${ }^{21}$ In the limited space of the United States, the Chinese thrive while white Americans are 'blotted from the record of nations and peoples'. ${ }^{22}$

Such rhetoric readily lent itself to narratives that understood future wars as fought, not between nations, but between races. ${ }^{23}$ For some white Europeans and their descendants, shared racial superiority was the glue for their global alliance. The Briton Cecil Rhodes, fighting in Matabeleland to clear the African inhabitants and establish white settlements, welcomed white people of 'goodwill' to colonize 'his' Africa, and many Americans (some experienced at warring against Native Americans on the USA's western frontier) accepted his offer. Roosevelt greatly approved of Rhodes's colonization project. ${ }^{24}$ William Delisle Hay's novel Three Hundred Years Hence (1881) is an imagined human history narrated from the future. The novel divides humankind into five types and in three hundred years only the Xanthochroi group still survive - otherwise known as Caucasians, whom 'Nature has selected to rule and populate the globe.' Germans, AngloSaxons, Scandinavians, Finns, Slavs and 'Light Celts' are some of the peoples gathered under the title Xanthochroi, and in the future other racial groups have lost their ethnic distinctiveness through breeding with the dominant racial category, or have become extinct, finding themselves unable to assimilate into white civilization (the fate of indigenous Australians in the novel). But this is not the whole story of 'The Fate of the Inferior Races'. When the world faces a Malthusian dilemma - an expanding world population on the verge of exceeding the planet's ability to produce sufficient food - some of the Xanthochroi assert 'let self-preservation be our excuse' and proclaim 'Death to the Negro! Annihilation to the Chinaman!' Nonetheless, the Union of Humanity declines to exterminate East Asians and Africans, and the narrative engineers an uprising of both peoples so their extinction becomes a justifiable act of white selfdefence. Using a new superweapon entitled 'the Chicago Bullet' fired from 'aërial craft', these groups are made extinct, to the narrator's sigh of relief:

After the extermination of the Inferior Races there was, as it were, a breathing-space. There were vast tracts of land awaiting occupants, and into which immigrants soon began to flock, changing the aspect 
of the country as they came, and bringing the advancing civilisation of the White Man along with them. ${ }^{25}$

With East Asia and Africa stripped of their human population, Three Hundred Years Hence posits the reoccupation of the land by Xanthochroi. In this future the Earth's population and capacity to produce food is balanced and the planet can inhale again. In the hands of the Xanthochroi, a group which the novel explains Nature has fitted out to prosper at the expense of inferior races, the latest military technology enables a genocide that leads to further, final settlement of the Earth by white peoples.

Closely shadowing Hay's themes, the American novelist and social reformer Ignatius Donnelly's novel Caesar's Column (1891) saw extermination as the solution to the overcrowded world of 1988, with its enormous disparity between the rich and poor, ruled over by (mainly Jewish) corrupt businessmen. An organization entitled The Brotherhood of Destruction eradicates most of the human race with airships and poison gas bombs. North America and Europe are destroyed, and befitting the genre's assumption that the parts of the world exterior to those continents are available for white settlement, the Swiss narrator and his peers 'set up a happy republic in Uganda' (there is some critical debate over how happy this resolution is). ${ }^{26}$ King Wallace's The Next War (1892) offers the extinction of African Americans as the solution to the USA's social problems. ${ }^{27}$ Air war returned in American writer Samuel W. Odell's The Last War; Or, Triumph of the English Tongue (1898), in which 'English-speaking peoples win their final battle against inferior races via an air force that rains incendiary bombs down upon the enemy'. The Anglophone bloc succeeds in imposing their language and 'customs of civilization' on the 'savage inhabitants' of Russia and Asia. ${ }^{28}$ The main features of The Last War were prefigured in the novel The Great War Syndicate (1889), written by Frank Stockton. These features included an 'Anglo-American Syndicate of War' which uses the threat of its devastating new 'Motor Bomb' to coerce the rest of the world to submit to its rule. The novel ends with 'all the nations of the world' beginning to 'teach English in their schools'. ${ }^{29}$ The Great Pirate Syndicate (1899), written by British novelist George Griffith, seems to have adapted more than just its title from Stockton's novel. In The Great Pirate Syndicate, overwhelming technological superiority in warfare was exercised once more by a transatlantic alliance of Anglo-Saxons, although not without some initial friction between the United Kingdom and the United States over the AlaskanCanadian border. The eponymous syndicate, Oceana Limited, is a secret organization pledged to support the British Empire - to which end they develop an arsenal of new weapons. One of the most devastating is the aerial Destroyer, able to shoot aerial torpedoes at cities. The language the 
Pirate Syndicate use towards (implicitly white) Americans professes their kinship juxtaposed against mounting belligerence: 'It's all very well to talk about ties of blood and kindred; but when it comes to hard cash and solid gold, in chunks, as Uncle Sam himself would say, it's a very different matter. We know how a pair of brothers will fight over a disputed will'. Nonetheless, when the nations of continental Europe turn against Great Britain, the US press appeal to their government for an 'Anglo-Saxon alliance' and the character Senator Walcott, returning to the family metaphor, called for the USA to stand with 'the brothers of our blood'. Supported by the Pirate Syndicate's paralyzing devices and 'aerial monsters [raining] down fire and death', the Anglo-US alliance forces the surrender of the rest of the world: 'the long-dreamed-of ideal of an Anglo-Saxon federation became a reality'. ${ }^{30}$ Griffith was returning to the content of his earlier novel, The Angel of the Revolution (1893), in which a leftwing terrorist organization possessing cutting-edge technology (a flying machine) leads a successful revolution against the capitalists and corrupt governments of Europe and America. ${ }^{31}$ In that novel, class conflict shades into race war: the victorious 'Federation of the English-speaking races of the world, [bonded by] kindred blood and speech and common interests' responds to an Asian invasion with 'a war [...] of extermination' fought with 'the most terrific powers of destruction that human wit had ever devised'. ${ }^{32}$

In the early 1980s the scholar of cataclysmic literature W. Warren Wagar connected the pre-1914 'apocalyptic race wars' to social Darwinism, and the perception of non-white peoples as a 'kind of "alien" menace'. ${ }^{33}$ As well as Hay's Three Hundred Years Hence, Wagar gives the example of British novelist M. P. Shiel's Yellow Peril series; in the first of these, The Yellow Danger (1898), Europe is overwhelmed by four hundred million Asian invaders driven by 'dark and hideous instincts' ${ }^{34}$ By this point at the end of the nineteenth century, the genre had its key tropes: future wars between European nations would be decided by technological maturity and preparedness, but when whites and non-whites clashed, the unchecked population growth of non-whites could potentially eradicate white peoples.

While one should be cautious about ascribing literary evolutions to any single historical event, the repercussions of the 1904-05 Russo-Japanese War are undeniable. The victory of an organized and well-equipped Japan over Russia drew international attention to Japan's ascendancy and reminded the world powers they would need to modernize to remain militarily credible. The influential American eugenicist Lothrop Stoddard, who belonged to Madison Grant's circle, saw the Russo-Japanese War as the first serious threat to 'white world supremacy'. ${ }^{35}$ America's future-war 
fiction focused attention on the Japanese as a specific threat, and scholars H. Bruce Franklin, John Rieder, David Seed and Patrick B. Sharp all note the racial politics of Jack London's future-war story 'The Unparalleled Invasion'. London provides an exemplary case because of his literary status and his journalism, which provides comparable evidence of his perception of the Asian threat, such as his 1904 article 'The Yellow Peril'. 'The Unparalleled Invasion' was written in 1907 and published in McClure's Magazine in $1910 .{ }^{36}$ Its narrative combines the two variants of the future-war story Clarke identified: it warns that failing to take national security seriously will lead the country to the edge of destruction, and it prophecies that technological innovation will give America the upper hand. Deployed at the last moment, that innovation eradicates the enemy and strengthens America's position in the world.

In London's short story, Japan drives the improvement of China's agriculture, industry and infrastructure, building railways, canals, telegraphs and factories, and accustoming its army 'to all the modern machinery of war'. 'China was at last awake.' Once Japan has served its narrative role as conduit and impetus for modernization its emissaries are ejected from China, along with all Westerners. The increase in productive power enables China 'to support a far larger population' than ever before. The 'fecundity of her loins' became its chief weapon; China 'was spilling over the boundaries of her Empire [...] with all the certainty and terrifying slow momentum of a glacier'. Western attacks from the sea are negligible. The size and uniformity of the Chinese is the essence of its threat: a French military expedition enters the country only to disappear into the mass. When restraint is asked of the Chinese leader Li Tang Fwung, his reply could be read as satirizing the language of white supremacism - if one ignored London's anti-Asian racism: 'We have our own destiny to accomplish. It is unpleasant that our destiny does not jibe with the destiny of the rest of the world $[\ldots]$ You have talked windily about the royal races and the heritage of the earth, and we can only reply that that remains to be seen. You cannot invade us.' American scientist Jacobus Laningdale has a technological solution, a biological weapon so powerful it decimates the population when dropped from the air. China experiences 'ultra-modern war, twentieth century war, the war of the scientist and the laboratory'. Using a language of extermination that the early twentieth-century German racial theorists would have approved of, the Chinese landscape is wiped clean - 'All survivors were put to death' and the international community begins 'the sanitation of China'. Other nations establish settlements there 'according to the democratic American program', in a heterogeneous 'intermingling of nationalities'. ${ }^{37} \mathrm{~A}$ hostile people to 
America's west are wiped out by a combination of war and disease, and the newly vacated land is occupied. The historical and mythic reference points of London's future vision are hardly subtle on this 'new frontier' ${ }^{38}$

Strong similarities exist between 'The Unparalleled Invasion' and Roy Norton's future-war narrative The Vanishing Fleets, serialized in various US newspapers during 1907 and collected in one volume in 1908. This story interprets the hostility between Japan and America as of an irrevocable 'purely racial character'. The first stage of the Asian invasion is the presence of migrant workers, what Norton calls the unwanted 'economic invasion from the Orient'. Japan subsequently stimulates the rise of China and attacks Hawaii and the Philippines. Norton describes this as a 'racial war', ${ }^{39}$ and the efficiency with which the modernized Japanese Navy progresses is a caution against letting 'new technology' fall 'into the hands of "enemy" races'. However, American scientists have invented a fighting machine as yet unknown to the world, a 'radioplane' that uses radioactivity to control gravity. This invention allows the USA to defeat the Japanese Navy and ushers in an era of American imperial domination around the world. ${ }^{40}$ Repeating a theme, Marsden Manson's pamphlet The Yellow Peril in Action: A Possible Chapter in History (1907) uses a speculated defeat to prod policymakers in the present. China and Japan seize Honolulu and blockade the USA's Pacific ports; America is wracked by race riots and fifth columnists sabotage the rail network. The USA is forced to sign a 'humiliating armistice' and Seed reads the story as Manson's attempt to persuade Congress to forbid immigrant labour into the country. ${ }^{41}$ In a return to London and Norton's deification of US technological ingenuity, John Ulrich Giesy's All for His Country was serialized in 1914 in Cavalier Weekly and published as a book in 1915. The Japanese launch a surprise attack on Hawaii and take California, occupying it easily because JapaneseAmerican immigrants assist the invaders. The narrative proposes these migrant workers travelled to America in the first place as the advance guard of the invasion. Japan's 'aërial bomb' swiftly dispatches the American Navy, leaving America about to accept a humiliating peace agreement. Seemingly intended by Giesy as an affront to the dignity of white Americans, ${ }^{42}$ Japan wants the USA to grant full citizenship and property rights to Japanese citizens, and to treat them as Caucasians, which includes accepting marriage between white Americans and the Japanese. This condition is the most offensive to the American President because it means sacrificing white racial purity: 'this last clause amounts to our subscribing to an Orientalization of our race - to the waiving of our birthright' ${ }^{43}$ With whites as nature's aristocrats, the narrative works to make it unsurprising that the Japanese would lust after the epitome of womanhood that white 
American females represent, and all the more reason to protect them from non-white sexual approaches. In a reversal of All for His Country's racial allegiances, Floyd Gibbons's novel The Red Napoleon (1929) imagined a Mongol invasion of the West led by the Soviet leader Karakhan. Karakhan presents the rape of white women by the Asian invaders as the attempt to end racial prejudice by mixing the human races into one, single human race, and while his project is ultimately foiled, through the Soviet leader Red Napoleon makes several indictments of American racism. ${ }^{44}$

The temporary success the Japanese enjoy in All for His Country is won by duplicity and new technology, and they are defeated by even more recent developments in aerial warfare, an 'aero-destroyer' designed by US scientist Meade Stillman. All for His Country exhorted white readers to remain vigilant against Asian connivance within and without the national borders, offering the reassurance that white America's survival could rely upon the unmatched scientific creativity of its people. ${ }^{45}$ In Robert A. Heinlein's later novel The Day after Tomorrow (1949; first published in 1941 under the title Sixth Column), the remnant of white America that survives a PanAsian invasion is forced to hide in the Rocky Mountains. They too develop a new scientific weapon and launch a successful resistance against the occupiers. ${ }^{46}$

Serialized in 1913 and published as a novel in 1914, H. G. Wells's The World Set Free: A Story of Mankind narrates a future war fought with atomic bombs, and while it exploits the tension between civilization and savagery, it does so in a less obviously racialized manner than the above narratives. Wells's novel dramatizes the disparity between humankind's highly advanced weapons and its competitive, savage nature, arguing that atomic war results from the failure of our social organizations to keep pace with our technological maturity. The World Set Free reaches for the racialized symbols of savagery in its description of a French aviator who retaliates when Paris is atomic-bombed. 'There was an exotic richness' about this aviator's voice, and in addition to his 'hairy and exceptionally big' hands he is 'a dark young man with something negroid about his gleaming face. ${ }^{47}$ The visual codes of racial blackness complement the novel's moral lesson: humankind must abandon its brutal, bestial inheritance if it is to transcend the destructive ramifications of its scientific ingenuity. ${ }^{48}$ In The World Set Free the forces of competitive barbarism destroy each other, opening the space for social progress.

After the commencement of the Great War in 1914, but before America entered the conflict in 1917, Europeans were the invaders again in US future-war fiction. Using the alarmist narrative structure, Julius W. Muller's The Invasion of America (1916) and Thomas Dixon's The Fall of a 
Nation (1916) depict future war to prompt America to augment its armaments. While they do not represent future race war, Dixon's novel is worth consideration precisely because America's enemies are not racial others. Foreshadowing invasion by the European empires, European immigrants posing as loyal American citizens begin a programme of sabotage. However, their allegiances ultimately lie with the United States, and they join an uprising organized by the leader of the woman's suffrage movement. The change of heart that Dixon's immigrants have is in marked contrast to the future-war stories where the 'enemy within' is of Asian descent. Dixon's 1905 novel The Clansman was made into D. W. Griffith's controversial 1915 film The Birth of a Nation. In this sprawling text the chaos generated by the Union victory in the Civil War and the Emancipation Proclamation requires the intervention of the Ku Klux Klan to bring stability (and a renewed racial hierarchy) to the United States. The title of Dixon's 1916 novel appeals to his existing readership and unsurprisingly in The Fall of a Nation the commonality of race makes it possible for white European migrants to realize, albeit late, that they have common cause with their white American compatriots.

In the 1920s, American future-war fiction continued to fear Asia, using extraterrestrial replacements to symbolize their perceived menace and alterity. Philip Francis Nowlan's narratives fit the stereotypical SF trappings of rocket ships, ray guns and heroic exploits. His hero Buck (originally Anthony) Rogers began life in a 1928 short story before being published in the books Armageddon 2419 A.D. (1928) and The Airlords of Han (1929), becoming a nationally syndicated comic strip on 7 January $1929 .{ }^{49}$ Sent into a sleep lasting hundreds of years, Rogers wakes up in the future and finds America's cities destroyed and the population driven into the countryside by a despotic, ruthless, coolly rational people: the Mongols. Seed dryly observes, 'In case the reader misses the point, we are told that their soldiers wear bright yellow uniforms. ${ }^{50}$ Rogers helps white America reassert itself and 'exterminate' the occupying force, who 'originated as a hybrid somewhere in the dark fastnesses of interior Asia, and spread [...] like an inhuman blight over the face of the globe'. ${ }^{51}$ The Mongols appear as a conjunction of races nature had designed to be separate, and having unnaturally mixed, their human pestilence overcame the surrounding peoples. Mercifully, Rogers reports, they have been wiped out and can never threaten the world again. At the behest of King Features Syndicate, comic-strip artist Alex Raymond created the Sunday newspaper cartoon Flash Gordon to compete with the Buck Rogers strip. Flash Gordon debuted on 7 January 1934, and it deployed a similar enemy, Ming the Merciless, from the planet Mongo. It was syndicated in more than 150 newspapers 
and was adapted to a radio show and three movie serials. ${ }^{52}$ Flash Gordon was another SF adventure narrative in which the racialized villain is a tyrant who desires white womanhood, a villain visualized with the iconography of the Yellow Peril. Ming's creation drew on the popularity of a character created by the English novelist Sax Rohmer, whose evil genius Dr Fu Manchu sought nothing less than the overthrow of the white world. ${ }^{53}$ The 1920s also saw the publication of Hector C. Bywater's novel The Great Pacific War: A History of the American-Japanese Campaign of 19311933 (1925), a meticulously detailed warning about Japan's plans to extend its empire across the Pacific, which highlighted specific geopolitical concerns (such as the strategic importance of Guam). ${ }^{54}$ Nonetheless, The Great Pacific War sits slightly outside the tradition outlined in this chapter. Bywater's avowed aim is not to write a prowar future history, and in the final lines he reminds readers that waging war is a waste of human life and capital.

By the late 1930s, the military prowess of the Third Reich and the fear of another war led to several future-war stories speculating on a future of Nazi dominance around the world. Yet even at this historical moment, future-war fiction, which saw the most important conflict of the future as the conflict between races, refused to disappear. R. C. Sherriff's The Hopkins Manuscript (1939) imagined the Moon crashing into the Atlantic Ocean. As the European nations fight among themselves, Selim the prophet from 'Teheran' assembles an army to follow him across Russia, Turkey and into Europe. There is little hope for the 'few thousand' Europeans making a last stand 'against these seething millions'. Western Europe is destroyed, and the novel as a whole is presented to readers as a manuscript recovered by the Royal Society of Abyssinia. It prefaces the narrative of Europe's fall with a reminder of recent history: 'for a hundred years after the collapse of the "Western Civilisation" the peoples of the reborn nations of the East indulged in an orgy of senseless destruction of everything that existed in their own countries to remind them of the "white man"'. Putting these words in the pen of a non-white character may be Sherriff's attempt to inoculate his novel against charges of racism, but there is little to choose between the barbarism of Selim's 'hordes' 55 and the American Yellow Peril fears. Extermination had become a generic staple by the 1930s, and not only in relation to interracial competition: 'Genocidal violence' had become a 'reflex mechanism' for the resolution of conflict in pulp science fiction. ${ }^{56}$

\section{Aerial War and Race War before 1945}

The development of indiscriminate aerial warfare often took on a racial character between the first manned motorized flight in 1903 and the 
bombardment of civilian populations during World War Two that culminated in the atomic bombing of Hiroshima and Nagasaki. Without wishing to minimize the advances in precision in this period, the act of attacking from the air reduced the opportunity to select individual or specific targets. For instance, while America's bombing philosophy was originally orientated around precision bombing, actually hitting those precise targets was rather more rare. ${ }^{57}$ In the instances that follow, success was gauged less by destroying certain strategic positions and more by accruing psychological capital at the enemy's expense by destroying their population.

During the Great War the Germans and the British bombed each other from the air with the intention of terrorizing the general population. By measuring success through the rather nebulous quality of emotional reaction, the proponents of 'morale bombing' made it difficult for critics to refute their claims. Raids by German aircraft on London in 1917 were targeting 'the morale of the English people' and the British responded with ill-executed bombings of German cities. At this stage the numbers killed were deemed less important than compelling the enemy population to feel vulnerable to the aerial threat. ${ }^{58}$ When a member of the British Air Board wrote to Hugh M. Trenchard, Commander of the Royal Flying Corps, telling him that the British raids need not be overly concerned with accuracy, Trenchard replied that the bombers were not very accurate anyway and pilots generally dropped their bombs in the middle of towns. This indiscriminateness showed a disregard for German life that embellished itself on the civilians' minds, and one German civilian wrote, 'one feels as if one were no longer a human being'.59 But had aerial war dehumanized conflict? Literary scholar Mark Rawlinson observes debates in World War Two that amplified those of the Great War in this regard: 'Aviation was, alternatively, affirmative or barbarically destructive of what it was to be human.' Aerial warfare accelerated the speed and enhanced the scale on which civilian populations could be bombed, but the aerial duel seemed to restore the chivalry, bravery and skill of individual combat lost elsewhere in twentieth-century total war. ${ }^{60}$ Between the world wars, air war theories and their dissemination in the UK argued this new way of fighting had erased the distinction between soldier and civilian, and millions of civilian deaths were projected. ${ }^{61}$

After the Great War, the bombing of civilian populations by the British shifted to its imperial colonies in a policy known as 'air policing'. In British Somaliland, a Mullah named Mohammed bin Abdullah Hassan, preaching a fanatical interpretation of Islam, gathered a following of around 10,000 people. Hassan declared a jihad on infidels, promising to drive them away, and the British Army had tried and failed to break his rule in the region. 
On 21 January 1920, five RAF planes attacked his compound at Medishe, bombing twice a day for three days, and the Mullah was driven out within a month. ${ }^{62}$ During May 1919, Afghan forces entered India via the Northwest frontier, and aircraft were used to drive the Afghans back. The Handley Page V/1500 Bomber, developed to attack Berlin, was used to drop bombs on Jalalabad, Dacca and Kabul. ${ }^{63}$ Britain's 'Air Control' of the Empire was used extensively in Iraq, whose large area posed difficulties to the collection of taxes. Open rebellion against British rule broke out, and the RAF was used to bomb villages that either would not pay taxes or were rebelling against the colonial government. One RAF officer opined,

One objective must be selected - preferably the most inaccessible village of the most prominent tribe which it is desired to punish. [...] The attack with bombs and machine guns must be relentless and unremitting and carried on continuously by day and night, on houses, inhabitants, crops and cattle. No news travels like bad news [...] This sounds brutal, I know, but it must be made brutal to start with. The threat alone in the future will prove efficacious if the lesson is properly learnt. ${ }^{64}$

This 'morale bombing' against defenceless targets was 'absurdly one-sided' . Atrocities against civilians were not necessarily condoned by policymakers: Winston Churchill, Secretary of State for War and Air, censured the airmen involved when women and children fleeing a village in Iraq were strafed as they sought cover. 'Air Control' was popular because it was cheap, and if the RAF wanted to hone a policy of civilian bombing then targeting the Empire's rebellious colonized subjects elicited little protest in the metropolitan centre. When Hugh Trenchard (now Chief of Air Staff) drafted a paper proposing that aircraft could be used to quell 'industrial disturbances' in India, Egypt, Ireland and England, Churchill made him remove Ireland and England because of the political opposition their inclusion would create. ${ }^{65}$

America's cities were subject to two manned aerial attacks in the twentieth century. Both attacks were perpetrated by Americans and the primary targets were African-American communities. The second bombing took place in 1985, when the police dropped an explosive device on a black ghetto in Philadelphia during a riot. The first demonstrates the collusion of the police in an attack that terrifyingly exploited air power's destructive force:

a mob of ten thousand whites invaded the black section of Tulsa, Oklahoma, looting and burning as they advanced. Armed blacks 
defended their homes, but their resistance was overcome with the help of eight airplanes, some manned by police, that rained improvised dynamite bombs on neighborhoods that the ground force had drenched with oil and gasoline. Most of the ghetto was burned to the ground, and between 150 and 200 black people, mostly women and children, along with fifty of the white invaders, lost their lives. ${ }^{66}$

The indiscriminateness of aerial bombing of urban civilian populations interwove with the callousness of the mob - the death of specific members of the black population of Tulsa appears secondary to the damage inflicted upon the community as a whole. This method of murder fitted the ambitions of unchecked racist antipathy. Similar superciliousness was evident in the Italian invasion of Ethiopia in the 1930s, when mustard gas was dropped onto civilians from airplanes. Gilroy writes that for the Italian government the Ethiopians were not full participants in human history they were 'judged to be a verminous part of the natural' world. ${ }^{67}$

While the atomic bombings of Hiroshima and Nagasaki were understood at the time as a qualitative difference in the way that wars could be fought, 'conventional bombing had already achieved such a high level of destruction that atomic bombs could not inflict dramatically more damage'. For instance, on the night of 9-10 March 1945, Tokyo was attacked by 334 aircraft dropping incendiary bombs. Civilian deaths were approximately 84,000 , which academic Robert A. Pape claims was greater than the loss of life at either Hiroshima or Nagasaki. ${ }^{68}$ The nature of incendiaries meant selecting targets was unnecessary: the objective was to create a firestorm that would rip through densely populated urban areas. ${ }^{69}$ The US bombing of Japan was not different from the aerial war in Europe in this regard: the Axis bombed Rotterdam in May 1940 after the city had surrendered, and similar aerial attacks on civilian populations in Warsaw, London and Coventry were condemned as immoral by the Allies. This did not stop the Allies bombing German cities in return. ${ }^{70}$ Dresden was remorselessly firebombed on 13-14 February 1945, killing between 35,000 and 100,000 Germans, mostly non-combatants. ${ }^{71}$

The animated film Victory through Air Power (1943), made by Walt Disney studios and distributed by United Artists, is an example of how civilian bombing campaigns were promoted to the public. As the official publicity stills from the film reiterate - constantly - Victory through Air Power was an animated version of Major Alexander P. de Seversky's book of the same name, which advocated using intercontinental bombers to strike Tokyo. The film advertised his policies by picturing Japan as a 'vicious grasping octopus' spread across the Pacific and only letting go of each island when each tentacle is burned off. Victory through Air Power argued Japan would 
be defeated more quickly by ignoring its tentacles: if the body of the octopus, Japan, was bombed into ruins, the tentacles or supply lines and bases, would automatically disintegrate'. This is a move away from accumulative strategic targets, and towards bombing Japan 'into ruins' and thus 'into submission' ${ }^{72}$

Given this wide acceptance during World War Two of bombing civilians, the war in the Pacific had an additional racial dimension. Both sides saw their enemy as a barbarian force committed to the absolute eradication of their civilization. Stereotypes and racism contributed to dehumanization, which in turn contributed to an 'obsession' with exterminating the enemy. Soldiers on both sides were reluctant to surrender voluntarily, not least because the enemy were occasionally unwilling to take prisoners. ${ }^{73}$ In this context, the Pacific theatre of conflict was - to quote the title from John W. Dower's book - a War without Mercy (1986). The US Admiral William Halsey saw 'the almost total elimination of the Japanese as a race' as the goal of the war in the Pacific, on the grounds that this 'was a question of which race was to survive, and white civilization was at stake'. Writers on both sides of the conflict saw it through the lens of a holy war against an unredeemable enemy. As we saw with the German race theorists, these Manichean dichotomies made the moral compulsion to eradicate the racial other unavoidable and the conduct of the war 'became fixated on exterminating the enemy - and verged, for some participants, on the genocidal' ${ }^{74}$ Halsey was hardly unique. During the battle for New Guinea in 1943, General Blamey told Australian troops they were 'fighting for nothing less than the cause of civilization itself'. He had in mind a civilization colour-coded as white and stretching back to ancient Europe, since he compared the Australian soldiers to Roman legionnaires. 'You know that we have to exterminate these vermin if we and our families are to live [...] We must go on to the end if civilization is to survive. We must exterminate the Japanese. ${ }^{75}$ Blamey's classification of the Japanese as vermin was shared by the American press and official channels of information, which added vipers, insects, rodents, lice and apes to the list, and American officers referred to them as spiders and scorpions. ${ }^{76} \mathrm{New}$ York political cartoonist Theodor Seuss Geisel (better known as Dr Seuss) drew the Japanese as cats, monkeys, a crab and a snake. ${ }^{77}$ These 'sharply racialized sentiments' ran from the ranks to the officers to the policymakers to President Truman himself, who described the Japanese as 'beasts' and 'savages', a continual rhetorical and visual representation of the Japanese as subhuman. ${ }^{78}$

Halsey's and Blamey's statements reproduce a common ideological trope during World War Two: the rule of white people in Asia was jeop- 
ardized by Japanese success, which made greater wars between Asians and whites more likely. In 1942, former American President Herbert Hoover advocated the continuance of the war against Japan, at whatever cost: 'Unless they are defeated [...] there will be in twenty-five years an Asiatic flood into South America that will make the Nazis look like pikers. ${ }^{179}$ Hoover feared Japanese victory because it would make the Americas prone to an unbearable level of Asian immigration. A future race war was predicted by the militant black leader Marcus Garvey in 1919. His newspaper Negro World prophesied an inevitable clash between Asian and white and saw it as an opportunity to address anti-black racism: 'one can foresee nothing else but an armed clash between the white and yellow races. When this clash of millions comes, an opportunity will have presented itself to the Negro people of the world to free themselves. ${ }^{80}$ The Japanese exploited this rhetoric to unify the peoples of its occupied territories, proclaiming PanAsian racial brotherhood to dispel national enmity. In November 1943, Tokyo was host to the Assembly of the Greater East Asiatic Nations, at which 'a succession of Asian leaders [...] placed the war in an East-versusWest, Oriental-versus-Occidental, and ultimately blood-versus-blood context'. In 1943, Roosevelt's personal emissary to India, William Phillips, described a growing 'color consciousness' drawing Asians together in opposition to whites. The Hearst newspapers declared Japan was a 'racial menace' and the result of its victory would be 'perpetual war between Oriental ideals and Occidental'. Even advocates of a free Asia 'warned of a Third World War between whites and nonwhites within a generation'. In spheres that were liberal and conservative, public and private, racist and antiracist, a future race war was speculated. ${ }^{81}$

To nuance this historical account, the extreme violence unleashed against the Japanese had several justifications, and not all were racial. Some argued the Japanese would never surrender; others contended that at the end of the Great War the Allies had made the mistake of not destroying Germany further, allowing it to rebuild and start another war twenty years later; others believed the psychological blow of annihilation was necessary to purge the militarism in Japan's national culture. ${ }^{82}$ In C. M. Kornbluth's 1958 SF story 'Two Dooms' a pivotal Los Alamos scientist, Dr Edward Royland, feels queasy about the moral consequences of his work on the atomic bomb. He visits a Hopi medicine man and wakes up in the twenty-second century: the atomic bomb was never developed, Japan successfully resisted invasion and the Axis counterattack defeated the Allies. In another Malthusian future, occupied America is weighed down by a surplus population of Asian invaders and their descendants. The rhetorical figure of the teeming mass in Kornbluth's description is of 
Yellow Peril vintage: they seized 'a nice sparse area' and 'bred irresponsibly just as fast as they could until the land was full'. ${ }^{83}$ When Royland returns to 1944, he immediately takes his latest work on the atomic bomb to his manager, encouraging readers to see the Manhattan Project as the necessary seal on destroying Japan and keeping the USA safe from Asian invasion. In relation to Hiroshima and Nagasaki, historian Andrew J. Rotter concludes that the desire to test the most expensive weapon ever made in the theatre of war, the leverage it would give the United States in negotiations with the Soviet Union, and the need to end the war in the Pacific decisively were the overriding reasons to drop atomic bombs. These remain contested issues, but Rotter's conclusions are more credibly argued than the assertion that American racism led the USA to use atomic bombs against the Japanese - although undoubtedly their perceived subhumanity meant that US policymakers had fewer reservations than if a Germany city had been identified as the first concrete target. ${ }^{84}$

In the late nineteenth and early twentieth centuries, many white Europeans and their descendants claimed to sit at the racial hierarchy's apex. That there should be some essential connection between such varying groups of people was rendered sensible by the claims of biological racial kinship. North America, South Africa, the Pacific and other locations were imagined as battlegrounds on which the race selected by the Christian God and evolution would win out. The proclamation of white superiority was accompanied by profound anxieties that the modern world was corrupting white manhood. Anxiously surveying North American and European racial degeneration, various scapegoats were identified and German race theorists and certain future-war writers proposed that the extermination of those scapegoats promised redemption. The indiscriminate use of the latest technology to wipe out non-white enemies was a recurrent feature of much Anglophone future-war fiction. This indiscriminateness was present when non-white civilian populations were bombed from the air in Somalia, Iraq and Afghanistan in the 1910s and 1920s, in Tulsa, Oklahoma in 1921, and in Japan in 1944 and 1945, although the blanket bombing of civilians was a feature of all aerial warfare in its early stages. As H. Bruce Franklin's War Stars: The Superweapon and the American Imagination (1988) implies, the compatibility of white supremacist race theory, future-war fiction and military policy suggests deep, shared psychic structures of racial arrogance. As we shall see, white supremacism is present in nuclear representations after 1945 in increasingly complex, contested and subtle ways. 


\section{Notes}

1. Daniel Pick, Faces of Degeneration: A European Disorder, c.1848-c.1918, Cambridge University Press, Cambridge (1989), p. 21.

2. Max Nordau, Degeneration (1892), University of Nebraska Press, Lincoln, NE (1993), p. 37.

3. Tami Davis Biddle, Rhetoric and Reality in Air Warfare, Princeton University Press, Princeton (2002), p. 16.

4. Quoted in D. W. Forrest, Francis Galton: The Life and Work of a Victorian Genius, Elek, London (1974), p. 255.

5. Arnold White, Efficiency and Empire, Methuen, London (1901), pp. 99100.

6. Karl Pearson, Francis Galton, 1822-1922: A Centenary Appreciation, Cambridge University Press, London (1922), p. 20.

7. Shawn Michelle Smith, “Baby's Picture Is Always Treasured”: Eugenics and the Reproduction of Whiteness in the Family Photograph Album' (1999), in Vanessa R. Schwartz and Jeannene M. Przyblyski (eds), The NineteenthCentury Visual Culture Reader, Routledge, New York (2004), pp. 364, 366-67.

8. Gerald Horne, 'Race from Power: U. S. Foreign Policy and the General Crisis of White Supremacy', in Brenda Gayle Plummer (ed.), Window on Freedom: Race, Civil Rights, and Foreign Affairs 1945-1988, University of North Carolina Press, Chapel Hill (2003), p. 50.

9. Mosse, Towards the Final Solution, pp. 96-98, 105-107.

10. Mosse, Towards the Final Solution, pp. 97, 105-107.

11. Quoted in Mosse, Towards the Final Solution, pp. 98-99.

12. Daniel Pick, War Machine: The Rationalisation of Slaughter in the Modern Age, Yale University Press, New Haven (1993), p. 177; John Ellis, The Social History of the Machine Gun, John Hopkins University Press, Baltimore (1986).

13. I. F. Clarke, Voices Prophesying War: Future Wars 1763-3749 (2nd edn), Oxford University Press, Oxford (1992), p. 71.

14. Clarke, Voices Prophesying War, pp. 39-41, 48.

15. Clarke, Voices Prophesying War, pp. 37, 31-32.

16. Clarke, Voices Prophesying War, pp. 53-54.

17. Biddle, Rhetoric and Reality in Air Warfare, p. 16. Le Queux was a prolific future-war novelist, as discussed in Martin Ceadel, 'Popular Fiction and the Next War, 1918-39', in Frank Gloversmith (ed.), Class, Culture and Social Change: A New View of the 1930s, Harvester Press, Brighton (1980), pp. 164-66.

18. Rieder, Colonialism and the Emergence of Science Fiction, p. 162 n. 3.

19. Clarke, Voices Prophesying War, p. 42.

20. Hugh Grattan Donnelly ['Stochastic'], The Stricken Nation (1890), in I. F. Clarke (ed.), The Tale of the Next Great War, 1871-1914: Fictions of Future Warfare and of Battles Still-to-Come, Liverpool University Press, Liverpool (1995), p. 165.

21. David Seed, 'Constructing America's Enemies: The Invasions of the USA', Yearbook of English Studies, 37.2 (2007), pp. 65-66.

22. Pierton W. Dooner, Last Days of the Republic (1880), Arno, New York (1978), pp. 256-57. 
23. Biddle, Rhetoric and Reality in Air Warfare, p. 13.

24. Horne, 'Race from Power', pp. 46-47.

25. William Delisle Hay, Three Hundred Years Hence (1881), in I. F. Clarke (ed.), British Future Fiction (vol. II), Pickering \& Chatto, London (2001), pp. 232, 251, 261-62, 270, 273.

26. John Carey (ed.), The Faber Book of Utopias, Faber, London (1999), p. 321.

27. Rieder, Colonialism and the Emergence of Science Fiction, p. 141; Edward James, 'Yellow, Black, Metal and Tentacled: The Race Question in American Science Fiction', in Philip John Davies (ed.), Science Fiction, Social Conflict and War, Manchester University Press, Manchester (1990), p. 28.

28. Biddle, Rhetoric and Reality in Air Warfare, p. 13.

29. Frank Stockton, The Great War Syndicate, New York (1889), p. 180, quoted in H. Bruce Franklin, 'Eternally Safe for Democracy: The Final Solution of American Science Fiction', in Philip John Davies (ed.), Science Fiction, Social Conflict and War, Manchester University Press, Manchester (1990), p. 152.

30. George Griffith, The Great Pirate Syndicate, F. V. White \& Co., London (1899), pp. 228-29, 5, 263, 286, 264.

31. Rieder, Colonialism and the Emergence of Science Fiction, pp. 140-41.

32. George Griffith, The Angel of the Revolution: A Tale of the Coming Terror, Tower, London (1893), pp. 281, 318, 322.

33. W. Warren Wagar, Terminal Visions: The Literature of Last Things, Indiana University Press, Bloomington (1982), p. 122; idem, 'The Rebellion of Nature', in Eric S. Rabkin, Martin H. Greenberg and Joseph D. Olander (eds), The End of the World, Southern Illinois University Press, Carbondale (1983), p. 167.

34. M. P. Shiel, The Yellow Danger, Grant Richards, London (1898), p. 109, quoted in Wagar, 'The Rebellion of Nature', p. 167; idem, Terminal Visions, p. 122.

35. Quoted in Horne, 'Race from Power', p. 50.

36. H. Bruce Franklin, War Stars: The Superweapon and the American Imagination, Oxford University Press, New York (1988), p. 37; Rieder, Colonialism and the Emergence of Science Fiction, p. 141; Seed, 'Constructing America's Enemies', pp. 67-68; Patrick B. Sharp, Savage Perils: Racial Frontiers and Nuclear Apocalypse in American Culture, University of Oklahoma Press, Norman, OK (2007), pp. 98-105. Sources disagree on the date 'The Unparalleled Invasion' was written.

37. Jack London, 'The Unparalleled Invasion' (1907), in Earle Labor, Robert C. Leitz, III, and I. Milo Shepard (eds), The Complete Short Stories of Jack London (vol. II), Stanford University Press, Stanford (1993), pp. 1234-46.

38. Sharp, Savage Perils, p. 105.

39. Roy Norton, The Vanishing Fleets, D. Appleton, New York (1908), pp. 45 .

40. Sharp, Savage Perils, p. 109.

41. Seed, 'Constructing America's Enemies', p. 71.

42. Sharp, Savage Perils, p. 111.

43. John Ulrich Giesy, All for His Country, Macaulay, New York (1915), p. 197. 
44. James, 'Yellow, Black, Metal and Tentacled', p. 29; Seed, 'Constructing America's Enemies', pp. 74-75.

45. Sharp, Savage Perils, pp. 111-12.

46. James, 'Yellow, Black, Metal and Tentacled', pp. 30-31; Seed, 'Constructing America's Enemies', pp. 68-70.

47. H. G. Wells, The World Set Free: A Story of Mankind, Macmillan, London (1914), p. 94.

48. Sharp, Savage Perils, p. 80.

49. Seed, 'Constructing America's Enemies', p. 68; Sharp, Savage Perils, pp. 112-13; James, 'Yellow, Black, Metal and Tentacled', pp. 31-32.

50. Seed, 'Constructing America's Enemies', p. 68.

51. Philip Francis Nowlan, Armageddon 2419 A.D., Ace, New York (1962), pp. 189-90.

52. Brian Walker, 'The War Made a Realist Out of Me', in Alex Raymond and Ward Greene, Rip Kirby (vol. I), Library of American Comics and IDW Publishing, San Diego (2009), pp. 14-15, 18.

53. Sharp, Savage Perils, pp. 114-15.

54. Seed, 'Constructing America's Enemies', p. 72.

55. R. C. Sherriff, The Hopkins Manuscript, Victor Gollancz, London (1939), pp. 350, 5 .

56. Rieder, Colonialism and the Emergence of Science Fiction, p. 142.

57. Stephen Budiansky, Air Power, Viking and Penguin, London (2003), pp. 169-80.

58. Biddle, Rhetoric and Reality in Air Warfare, pp. 19, 41-48; Budiansky, Air Power, pp. 95-96, 101.

59. Quoted in Andrew J. Rotter, Hiroshima: The World's Bomb, Oxford University Press, Oxford (2008), p. 47.

60. Mark Rawlinson, British Writing of the Second World War, Clarendon Press and Oxford University Press, Oxford (2000), pp. 56-59.

61. Ceadel, 'Popular Fiction and the Next War, 1918-39', pp. 161-82.

62. Budiansky, Air Power, pp. 139-42.

63. Lawrence James, Raj: The Making of British India (1997), Abacus, London (1998), pp. 475-76; Budiansky, Air Power, pp. 141-42.

64. Quoted in Budiansky, Air Power, p. 143.

65. Budiansky, Air Power, pp. 144-46.

66. Franklin, War Stars, p. 95.

67. Paul Gilroy, Darker Than Blue: On the Moral Economies of Black Atlantic Culture, Belknap Press of Harvard University Press, Cambridge, MA (2010), p. 70 .

68. Robert A. Pape, Bombing to Win: Air Power and Coercion in War, Cornell University Press, Ithaca, NY (1996), pp. 88, 103.

69. Dower, War without Mercy, pp. 40-41; Pape, Bombing to Win, p. 103.

70. Richard Overy, 'Introduction', in Sebastian Cox and Peter Gray (eds), Air Power History: Turning Points from Kitty Hawk to Kosovo, Frank Cass, London (2002), pp. xv-xvi.

71. Biddle, Rhetoric and Reality in Air Warfare, pp. 254-56.

72. Quotations are taken from the official publicity stills for the film, which 
are available for consultation in the Bill Douglas Centre for the History of Cinema and Popular Culture at the University of Exeter. The catalogue numbers for the stills quoted from are: 50926, 50992, 50954, 50937, 50940.

73. Dower, War without Mercy, pp. 11-12.

74. Dower, War without Mercy, pp. 55, 7, 27, 29.

75. Quoted in Dower, War Without Mercy, p. 71.

76. Rotter, Hiroshima, pp. 166-67.

77. Richard H. Minear, Dr. Seuss Goes to War, The New Press, New York (1999), pp. 142-43, 145, 152, 212.

78. Rotter, Hiroshima, pp. 166-68.

79. Quoted in Horne, 'Race from Power', pp. 53-54.

80. Quoted in Horne, 'Race from Power', pp. 51-52.

81. Dower, War without Mercy, pp. 6-7.

82. Dower, War without Mercy, p. 56.

83. C. M. Kornbluth, 'Two Dooms' (1958), in Frederick Pohl (ed.), The Best of C. M. Kornbluth (1976), Ballantine Books, New York (1977), p. 320.

84. Rotter, Hiroshima, pp. 168-72. 


\section{Inverted Frontiers}

We were the most powerful nation. Who could tell us any longer what was fashionable and what was fun?

F. Scott Fitzgerald ${ }^{1}$

The claims in Fitzgerald's essay ‘Echoes of the Jazz Age' (1931) have influenced the collective memory of the 1920s as an era characterized by fashion, disaffection with orthodoxies and an American cultural nationalism propelled by the growing international status of Hollywood cinema and jazz music. After the Great War - which Fitzgerald and others termed the 'European War', ${ }^{2}$ signifying the USA's aloofness - America had emerged economically and culturally dominant. Many European states were in debt to the country across the Atlantic as a result of war loans. ${ }^{3}$

These are just 'echoes' in 1931; the hubbub of the 1920s gave way to the deprivation of the Great Depression as a consequence of the 1929 economic crash. Fitzgerald captures the dizzying excitement of America in the 1920s, yet his mode is nostalgic and by the essay's end he acknowledges that historical events have severed the Jazz Age from his viewing position in 1931. His narration of the 1920s is a combination of confidence in the dawning of an American age and the anxiety that this confident era was 'borrowed time'. ${ }^{4}$ American cultural texts produced after 1945 were also subject to profound anxieties about the longevity and solidity of American power, even if the nation's economic and cultural strength seemed unmatched.

This chapter focuses on American novels and short stories that depict the post-nuclear-war United States needing the intervention and tolerance of other nations to survive, namely Whitley Strieber and James W. Kunetka's novel Warday (1984), William Tenn's short story ‘Eastward Ho!' (1958) and Michael Swanwick's short story 'The Feast of Saint Janis' (1980). These texts belong to a larger genre of speculative fiction depicting the invasion of America, some of which were discussed in the preceding chapter. Seed describes this genre as a 'long tradition in American writing' exploring the 'underside of manifest destiny' (the belief that the USA's expansion across the continent was inevitable and divinely willed) and exploiting 'the fear of failure, defeat, and subversion'. ${ }^{5}$ America's global 
position from the 1950s to the 1980s is comparable to the British Empire's in an earlier period, and the texts analysed in this chapter can be filed alongside late-nineteenth-century British visions of future catastrophe. Such visions of the 'imperial homeland' falling into ruins or being 'reduced to savagery' were based on 'the premise of England's imperial supremacy and its centrality to the world economy'. By offering readers 'the exhibition of the mighty humbled', British writers were asserting their empire's contemporary greatness while expressing the ambivalences and anxieties that a position of global eminence entails. ${ }^{6}$ As with the catastrophes of latenineteenth-century British speculative fiction, Warday, 'Eastward Ho!' and 'Saint Janis' are tailored to the geographical and temporal moment of their production. These three texts share a satirical Weltanschauung fixed upon injustices in American society: racism, economic injustice, the danger of nuclear weapons, crimes committed during the history of settlement and the irrationality of US consumerism. These are post-apocalyptic visions where the lack of national optimism (evident in ironic or melancholic tones) mourns the passing of American greatness, rather like Fitzgerald's wistfulness in 'Echoes of the Jazz Age'.

Consideration of these texts complements the analyses of future-war fiction in Patrick B. Sharp's study Savage Perils. Sharp posits a Darwinian struggle for survival between races as the leitmotif of what he defines as 'nuclear frontier fiction' between 1946 and 1959. In this genre, nuclear attack fulfilled the symbolic function that the frontier performed in primal narratives of US nationhood: forced to rely upon their innate skills and intuition, certain types of American would reveal their natural right to thrive at the expense of others (in the 1964 film Fail Safe, the character Groeteschele urges an American nuclear strike against the USSR and asserts 'those who can survive are the only ones worth surviving'). The terra incognita of narratives of the American frontier and European cartography provided a flattened (historically and physically) plane on which heroic masculine adventures could be performed. ${ }^{7}$ Depictions of post-apocalyptic landscapes are often congruous with these spaces of settlement, not least in terms of their narrative function, providing the opportunity for heroes to prove their bravery by penetrating and settling the unknown. This has been noted by several SF scholars. M. Keith Booker suggests postapocalyptic worlds offered a desirable escape into fantasies of settlement, becoming 'a new version of [the] American frontier that offers renewed possibilities for adventure that are no longer available in the routinized [sic] world of contemporary America' ${ }^{8}$ Gary K. Wolfe sees the 'new frontiers' of the 'depopulated', 'post-holocaust' world as making possible 'the sort of heroic action' constrained by the 'corporate, technological world'. 9 
I. F. Clarke hails the nuclear-war survivors of Leigh Brackett's novel The Long Tomorrow (1955) as 'pioneers of time-to-come' retracing 'the national epic of the frontier'. ${ }^{10}$ This reading is entirely appropriate for Brackett, who wrote scripts for Western films and won a Golden Spur Award from the Western Writers of America. ${ }^{11}$ Of the 1980s post-apocalyptic film genre partly inspired by the popularity of the Mad Max trilogy, Joyce A. Evans comments, 'Again and again, a surviving hero is confronted with a frontier to conquer, a civilization to rebuild'. ${ }^{2}$ Kim Newman tracks the migration of plots and actors from Western films into the post-apocalyptic dramas Cherry 2000 (1987), World Gone Wild (1988) and Neon City (1992). ${ }^{13}$ For Mick Broderick, the post-nuclear-war survivalist fantasies are highly reactionary [,] reinforcing the status quo by the maintenance of conservative social regimes of patriarchal law (and lore)' ${ }^{14}$ Broderick's point is relevant to Robert Heinlein's novel Farnham's Freehold (1964), in which the actions of the father, Farnham, ensure his family's survival by resurrecting a frontier lifestyle. Farnham's first reaction to the post-apocalyptic landscape is to 'survey it'. ${ }^{15}$ Broderick's frame of reference is film, but the 1980s was a popular time for post-nuclear-war survivalist fiction and Brians claims 'over a hundred violent pulp novels for men' were published in this genre. Brians singles out the books in Jerry Ahern's Survivalist series as particularly influential, with their 'absurd macho cover art' and 'their philosophy that the only hope for the future lies in developing the skills to fight and overcome the menaces which will multiply in the wake of World War III'. This genre has a corollary in the children's fiction marketplace in the form of Barbara and Scott Siegel's Firebrats series. ${ }^{16}$

The post-nuclear-war future need not be Earthbound. Outer space has provided an arena in which narratives of discovery and settlement - or, colonization and expropriation - can unfold. ${ }^{17}$ Narratives of exploration and encounters with alternative forms of life in outer space (perhaps most famously in the Star Trek universe) are sometimes set in a future where humankind has rebuilt itself from (the threat of) nuclear war. ${ }^{18}$ Given the recurrence of colonizing new worlds in SF, Carl Abbott has shown the importance of 'Homesteading on the Extraterrestrial Frontier' (2005) in American SF texts: 'Homesteading is a particular facet of the complex processes by which agriculturalists settle "empty" or underdeveloped territories'. With reference to Earthbound post-nuclear-war settings rather than outer space, this chapter builds on Abbott's conclusion that a 'growing body of science fiction has interrogated and complicated [the] popular history ${ }^{19}$ of courageous Americans of European descent conquering the West. ${ }^{20}$

As mentioned above, in Sharp's interpretation it was 'the white fron- 
tiersmen and the white frontier families [who embodied] "American" virtues as they fought to overcome the corruption of modern civilized life and the savagery of the nuclear frontier'. Sharp situates nuclear frontier fiction on a historical line stretching into the nineteenth century and in relation to Darwinian notions of technology as a lever of evolutionary advantage: 'For Darwin, the victories of civilized Europeans over their savage foes were due to technological superiority and were therefore just another example of natural selection' ${ }^{21}$ Yet many texts question the notion of technological superiority as a guarantor of evolutionary survival, since advanced technology such as nuclear weapons seem to compromise the survival of the people using them. Poul Anderson's short story 'Tomorrow's Children' (co-written with F. N. Waldrop in 1947) criticizes the assumption that the inevitable victors on the nuclear frontier will be white Americans in any recognizable form. Radiation has caused a marked increase in human mutation, and the narrative pivots between Colonel Hugh Drummond's and President Robinson's approaches to the situation. Robinson, whose wife is pregnant, believes in a eugenic solution to preserve 'our culture [...] our historical continuity', which Drummond opposes for 'repeating the old Herrenvolk notion'. To use the German word for 'master race' in a story published shortly after World War Two inevitably recalls the genocidal policies the Nazi Party undertook to ensure Aryan racial purity. Robinson describes his plan frankly as 'Racial death. All mutants and their parents to be sterilized whenever and wherever detected.' Drummond opposes his colleague's demonization of genetic variation, arguing 'the only way to sanity - to survival - is to abandon class prejudice and race hate altogether, and work as individuals. We're all...well, Earthlings, and subclassification is deadly.'.22 What Drummond professes is akin to the planetary humanism identified by Paul Gilroy, whereby environmental, military and economic crises compel us to define humankind by our shared inhabitation of a beleaguered planet. ${ }^{23}$ This point is also made in Leslie Marmon Silko's novel Ceremony (1977), which concerns the return of Tayo, a Native American soldier, to his tribe's reservation in New Mexico after the end of World War Two. While he is staying with the old man Betonie, Tayo reflects on the poverty of the Native American environment and the 'world of comfort' white Americans live in, a world built on land stolen from Native Americans and promises not kept. Betonie tries to mute Tayo's vengeful desires, telling him 'you don't write off all the white people, just like you don't trust all the Indians'. As he stands on a mesa near a uranium mine, Tayo's imagination takes in the test site for the first atomic bomb and the complex at Los Alamos where it was constructed. He sees that this new world of atomic weapons has 'no 
end', 'no boundaries', and from that moment on 'human beings were one clan again, united by the fate the destroyers planned for all of them, for all living things; united by a circle of death that devoured people in cities twelve thousand miles away'. ${ }^{24}$

Warday, 'Eastward Ho!' and 'Saint Janis' do not take nineteenth-century racial hierarchies for granted. These three stories invert the central conceit of nuclear frontier fiction so World War Three actually leaves the USA open to recolonization. In these texts the iconography of the frontier is reversed, using white settlement in North America to signify primitivism in opposition to the civilizations of the Sioux, New Africa, Japan and Britain. A satirical predecessor to these narratives - one that appeared before the most rapid spread of America's borders - is contained within Washington Irving's History of New York (1809). Irving speculates on an invasion of Earth by Moonmen, made possible by their superior technology. Irving parallels the encounter between Moonmen and Earthlings with the encounter between European settlers and Native Americans. The Moonmen find human skin colour - 'a variety of unseemly complexions, particularly of a horrible whiteness' - objectionable, since they themselves are 'pea green'. They oppose human life fiercely because they look different, and the Moonmen interpret this difference as inferiority. Accordingly the Moonmen proclaim that 'the earth [...] is inhabited by none but a race of two legged animals [...] they are considered incapable of possessing any property in the planet they infest, and the right and title to it are confirmed to its original discoverers'. The 'original discoverers' are, of course, the lunar visitors. The justifications of the European colonizers appear unjustifiable and unreasonable when articulated by the Moonmen. Certain of their superiority and therefore their right to the Earth, the Moonmen proceed as the Europeans did:

[The Moonmen] seize upon our fertile territories [...] and when we are unreasonable enough to complain, they will turn upon us and say - miserable barbarians! ungrateful wretches! - have we not come thousands of miles to improve your worthless planet[?] [Their] patience shall be exhausted, and they shall resort to their superior powers of argument - hunt us with hypogriffs, transfix us with concentrated sun-beams, demolish our cities with moonstones [...] they shall graciously permit us to exist in the torrid deserts of Arabia, or the frozen regions of Lapland, there to enjoy the blessings of civilization..$^{25}$

Europeans took the Native Americans' land because they were more powerful, and in so doing, lost all moral justification for being in America. 
Therefore, Europeans cannot complain if a more powerful force displaces them in the future. Franklin brings Irving together with H. G. Wells's alien invasion narrative The War of the Worlds (serialized in 1897) to make a case for their shared resistance to European and American expansion and the hubris underpinning it. ${ }^{26}$ Irving's early satire of settlement is strikingly prescient. It makes several literary moves that anticipate those discussed in this chapter, primarily the use of a future war and its aftermath to question the righteousness of European colonization and the automatic assumption of white superiority.

For the rest of this introduction, I will discuss Fiskadoro (1985) by Denis Johnson and The Lost Traveller (1976) by Steve Wilson, two novels that have clear affinities with Warday, 'Eastward Ho!' and 'Saint Janis'. However, they do not invert the racial and civilizational polarity of the frontier as such. In both texts non-white communities are posited as an alternative to Western civilization; this alternative is celebrated in The Lost Traveller but rendered unsettling in Fiskadoro.

Fiskadoro has two key points of comparison with Warday, 'Eastward Ho!' and 'Saint Janis'. First, the final scenes imply that the annexation of the Florida Keys by Cuba is imminent. Second, the character Mr Cheung is haunted by an impression of a nuclear blast that pays homage to Melville in its compulsive iteration of the bomb's whiteness. Cheung is nauseated as the 'White Dot' explodes into 'the All White, the Ever White, the Ultimate White of the Nucleus, the Atomic Bomb', and it is ironic that this 'All White' weapon has not reinstated a world of white American privilege. In fact, the Keys communities are difficult to characterize as a whole. On one hand, the racial, ethnic and religious intermixture of the Keys communities is commonplace and accepted; on the other, primitivist tropes mark out the atavism of specific non-white groups. These unfathomable and backward groups in Fiskadoro are the Israelites, a 'savage people' who appear to follow Rastafarianism, and a group known as the Quraysh, who practice a version of Islam. The third-person narrator begins the novel by speaking through the idiom of the Keys communities, accrediting Allah, the Lord, Quetzalcoatl, Bob Marley and Jesus with the status of gods, an example of the cultural intermixture in the novel which would be inadequately understood by imposing the dichotomous compartments of the frontier model. ${ }^{27}$

In Lost Traveller, the argument that nuclear war has rebuked the white settlement of North America is also put forward, but this disruption seems temporary. In the novel, the USA is reduced to a collection of feuding states jostling for territory, divided ideologically and physically by irradiated 'Dead Lands'. The novel's antiheroes belong to the gangs of Hell's Angels 
that protect the Fief, a kingdom where California used to be. Their main rival is the dictatorial Eastern Seaboard Federation, envisaged as a version of the United States in the mid-nineteenth century. The Federation is in thrall to the valuable cultural capital bound up in the British accent, and it proclaims to be leading a 'civilising mission' in its 'great drive westward'. The 'southern statelets' on the Gulf coast, which had been organized into an oil Cartel, are militarily occupied by the Federation. Confident that 'God was on their side', the Federation pushes further west, warning that lone individuals and families are threatened by 'Johnny Redman'. It is difficult to see what kind of role Native Americans will have in the Federation's plans, as one Federation officer professes (with feigned sympathy) that the 'poor devils' do not 'last very long' doing the labour of white men. ${ }^{28}$

During the successful war to repel the Federation's invasion of the Fief, the protagonist Long Range defects from the Hell's Angels to join a Lakota tribe. The novel chimes with the USA's revaluation of Native American culture in the 1960s and 1970s, evidenced in the American Indian Movement, best-selling revisionist histories and the small number of Hollywood films offering a Native American perspective on the USA's expansion. ${ }^{29}$ The Lakota in Lost Traveller are presented as the spiritual balm that Long Range needs, reconnecting him with nature and a meaningful existence. At the centre of the novel is a 13-page sequence recounting the rituals that initiate Long Range into the tribe, following which he reaches a richer state of consciousness. By the end of Lost Traveller, the Fief is copying the bad example of the defeated Federation and the rebuilding of American society progresses in step with the alienation of human beings from nature, from other humans and from their own desires. In the novel's representation of the Fief and the Federation, both of which follow recognizable Western models of statecraft, laws and government interference are essentially inhibitive of human freedom. This is figured as a disease: 'a bad case of civilisation'. While the Lakota are still harassed by the Federation at the end of the narrative, Long Range has become a 'holy man' and a 'great warrior' who rallies the tribe under his leadership. Long Range's comrade Milt tries to remain in the Fief but it is only the Lakota community that can guarantee his existential wellbeing. In a euphoric finale, Milt casts off his gang colours into a fire and is renewed in rapturous, baptismal imagery: 'upwards he went with the wash of the flames'.

The novel's criticism of Western society through the Federation's authoritarianism and expansionism is put in the mouth of Professor Sangria, snatched from the Federation by Long Range and Milt. What is 'truly disturbing' for Sangria 'is the way in which the Federation is duplicating rapidly the mistakes of former times, the times before the great war. 
Principally, a central government which concentrates power and wealth in itself, serves its own preoccupation with control and growth and ignores the real needs of the communities it subjects.' The Professor wants humankind to take advantage of 'the resources of an enlightened science' but Milt's response - 'I'll bet [...] they talked just like that before BLAM [the nuclear war]' - undercuts the Professor's confidence in science as the answer to this 'second dark age'. ${ }^{30}$ Despite the Professor's erudite argument, Long Range stubbornly insists on the truth contained in 'Indian myths and beliefs'. Long Range believes humans are all part of nature, they should never 'lose sight of that', and he knows this to be correct simply because he has felt it so strongly. In the narrative of Lost Traveller, nuclear war has made the return to nature more possible by weakening the previous social order. This is tied to the Native American characters' interpretation of nuclear war as an interruption to their subjugation by white people: Black Horse Rider says the war was seen 'as the time prophesied for so long by [Native American] wise men, the end of a cycle, when the Wasichu, the white man, and his ways were swept away'. No longer 'captives of the whites', the Native American population grows on America's Great Plains. 'The old ways returned, and there were mighty warriors, for they felt they were living the birth of a new first age, an age of great spirit power.' Remembering the earlier dispossession of Native American territory, the tribes now 'ruthlessly' protect their land. ${ }^{31}$

In contrast to the three main texts discussed in this chapter, Lost Traveller is not a reversal of America's narrative of the frontier. It replays the frontier with a sentimentalism and fatalism reminiscent of James Fenimore Cooper's The Last of the Mohicans (1826), a novel set in British North America during the Seven Years War (1756-63). Late-twentieth-century literary criticism of Mohicans investigated how the novel related to environmentalism, at the same time Native Americans were stereotyped as 'a symbol of Green consciousness and New Age spiritual values'. ${ }^{32}$ Whitley Strieber's post-nuclear-war children's novel Wolf of Shadows (1985) implied, through an epigraph from Chief Luther Standing Bear, that nuclear war was a consequence of straying from respect of nature, and as a consequence, respect for other human life. ${ }^{33}$ Much earlier, Stuart Cloete's two-part magazine serial 'The Blast' (1947) juxtaposed Native American primitivism against more complex white American technology in order to criticize the latter and link it to the nuclear weapons that had ravaged the world of the future. ${ }^{34}$ Lost Traveller fits into this trend of posing Native Americans as a desirable alternative to Western materialism. Like Cooper's novel, where the white protagonist Hawkeye (whose racial purity is repetitiously emphasized) has learnt from the dwindling tribe of Mohicans, 
Long Range has been educated by the Lakota and provides them with energy and leadership in return. It is important Native Americans have passed rituals and knowledge down to white acolytes since both narratives fatalistically suggest the Native Americans are poised to die out. The carbine rifle Long Range quickly learns to use evokes Hawkeye's gun, from which comes Hawkeye's nickname La Longue Carabine ('carabine' is the French word from which 'carbine' derives). Lost Traveller is unequivocal about the superiority of the Lakota's lifestyle but less sure about its chance of longterm survival: Long Range rallies the Lakota's morale while their herds contract in size. On this nuclear frontier, the struggle of Native Americans (led by a noble white man) appears brave but doomed and the alternative they represent is significant symbolically, as a model for readers in the 1970s disaffected with Western capitalism. It is not represented as a society likely to be able to resist white incursions in the future of the diegesis.

Warday, 'Eastward Ho!' and 'Saint Janis' show an awareness of the prejudices, greed and desires that European imperialism and American expansion projected onto the peoples destroyed as part of colonization. These texts revisit the atrocities perpetrated in America's past, and revalue those cultures often denigrated or annihilated by the expansion of American cultural and military power. They strain against the historical narratives of Manifest Destiny and American Exceptionalism (the belief that American democracy is unique and other nations would benefit from emulating it). In addition, these texts ask if American cultural, industrial and technological achievements will ever be reached again, and whether the nuclear arms race is a reason not to restore the USA to its post-1945 status. Adding further complexity, the world capitalist economy the United States was ideologically committed to promote appears as one of the vehicles by which America is recolonized.

\section{Inverted Frontier}

William Tenn's 'Eastward Ho!' projects a future where Native American nations have expanded and prospered while white American settlement shrinks. It is largely set in the 'neat ruins' of Trenton, New Jersey, roughly one hundred years after a nuclear war has reduced the United States to a small territory on the eastern seaboard with New York City as its capital. Native Americans have moved in to Trenton, the furthest southern extent of the United States, and Jerry Franklin (eldest son of a senator) has been commissioned to negotiate with these invaders. Expecting the Seminole, Franklin discovers that the invaders are Sioux led by the charming Chief Three Hydrogen Bombs, and while he is demanding the Sioux's with- 
drawal from Trenton, the United States is invaded from the north by a coalition of the 'Ojibway-Cree-Montaignais'. ${ }^{35}$ Assisted by Sylvester Thomas, ambassador to the Sioux from the Confederate States, and with Chief Three Hydrogen Bombs's knowing collusion, Franklin and his party escape to Asbury Park, where refugees from the United States have gathered and the remnants of the US Navy are positioned.

In this future, America has reverted back to its frontier state. Native Americans and European settler colonies coexist with varying degrees of hostility, technology is modest and subsistence agriculture is the key industry. The land to the west of the United States symbolically represented adventure and the opportunity to make a fortune. While a few texts through the centuries have been entitled Westward Ho - with or without the exclamation mark - Charles Kingsley's 1855 novel (with exclamation mark) is probably the most well known; Tenn may have been familiar with the 1935 Western film featuring John Wayne. Reversing the polarity of which point of the compass held out the promise of freedom and wealth, the title is the first instance of the short story's inversion of classic frontier narratives. More follow: it is the (white) USA that is being hemmed in and pushed off their land by Native American peoples. When these white Americans protest that Native Americans keep making and breaking treaties designed to preserve white land, the Native Americans declare they will use the land more efficiently: 'You don't use most of the land you have. Should we sit by and see the land go to waste[?] ${ }^{36}$ The Chief connects his ethical right to white territory to the practical politics of Lebensraum, citing the dwindling white population and the expanding Sioux population. During the nineteenth century, many key American military and political figures took a dim view of Native Americans inhabiting land that could be utilized by whites: Lewis Cass, Secretary of War, dignified the 1818 military campaign against Native American villages in Spanishowned Florida as necessary for the progress of civilization and improvement'. ${ }^{37}$ General William Sherman decried Native American 'attempts at civilization [as] simply ridiculous'. Unable to assimilate into white achievements, for Sherman extermination held out the sole means of preparing the West for civilization: 'The more we can kill this year, the less will have to be killed the next year. ${ }^{38}$

In a reading relevant to Sharp's discussion of nuclear frontier fiction, the re-ascendancy of Native American nations is accounted for using the concept of survival of the fittest in its original Darwinian sense: the species that survive to reproduce are those best matched to their environment. Readers of Tenn's short story are invited to believe that after a nuclear war the Native Americans' tribal structure enabled them to adapt quickest to 
the new conditions. Rather like the way the material expansion of the United States was ideologically driven by Manifest Destiny, in 'Eastward Ho!' the social adaptability of Native Americans is translated into the metaphysical inevitability of their power: 'the Indians were so queer, and so awesome. Sometimes you thought that destiny had meant them to be conquerors, with a conqueror's careless inconsistency. Sometimes...'39 Given that in this future the technological emblems of civilization (microscopes, guns and oil lamps) are owned and operated successfully by Native Americans, their pre-eminence seems authored not only by God but by the Darwinian discourse cited by Sharp in which tool-making determines the supremacy of species. Tenn's short story plays a precarious game, whereby the interactions and comforts of the Native Americans are much more familiar to most readers of 'Eastward Ho!' than the anachronisms and abject existence of the future United States, but we experience the Sioux through the narrative voice of Franklin, whose language comments on the suspicion, inscrutability and unpredictability that characterized some representations of Native Americans.$^{40}$ The ambiguity of this presentation of Native Americans is implied by the 'Sometimes...' that Franklin appends to his appraisal of the Sioux. This undercuts the certainty of Franklin's thoughts at this point in the narrative and leaves the reader unsure how far the Native American characters deserve our emotional allegiances.

The representation of white Americans as struggling for political recognition in the face of apathy and outright racism should also be understood in the context of the civil rights movement of the 1950s. By posing white Americans, and particularly white men, as the most marginalized and embattled demographic group of the nation's future, 'Eastward Ho!' could be read as a conservative tract protesting the goals of the civil rights movement: unless the interests of heterosexual white men are loudly defended, their rights will be eroded and they will be subjected to the racism and violence depicted in the story. However, several aspects of 'Eastward Ho!' mitigate against such a reading, and its subject may ultimately be the insidiousness of supposedly liberal positions. The 1954 Brown v. Board of Education of Topeka, Kansas Supreme Court decision gave legal impetus to racial desegregation, but President Eisenhower hoped that its progress would be slow. In another example of this gradualism, failed Democratic Presidential candidate Adlai Stevenson earned the ire of a black audience in Los Angeles in 1956 when he said 'we must proceed gradually, not upsetting habits or traditions that are older than the Republic'. ${ }^{41}$ In 'Eastward Ho!', some of the Native Americans in the story are unquestionably racist, and while the Chief's tone is far less strident, he too shares Makes Much 
Radiation's belief in white inferiority compared to Native Americans, praising Franklin with 'You look like a responsible man for a paleface'. The Chief not only re-uses language previously represented as offensive in the narrative ('paleface'), but by foregrounding Franklin's pronounced responsibility as uncharacteristic for his race, the Chief implicitly asserts the irresponsibility of whites generally. The Chief's praise for Franklin comes as he gives him a gun, emphasizing the trust he places in the US envoy, saying 'it's the individual that counts'.$^{42}$ Once more the patronizing language used confirms that the Chief sees whites en masse as the object of his pity, but distinctive people within that mass can be selected and trusted. To see whites as capable, as individuals, of bettering their lot, while reluctant to respect their rights collectively by altering social attitudes on a wider structural scale appears to be the text's critique of the essentially conservative position of only uplifting trusted members of a minority.

Tenn takes productive liberties with his inversion of the frontier motif. If it was an absolutely faithful reversal of the nineteenth-century frontier, then rather than running East to West, white civilization displacing Native American savagery, it would run West to East, with Native American civilization displacing white savagery - which the story does do. But it is not the Native Americans who deliver the exclamation of the short story's title. The white Americans proclaim 'Eastward Ho!' as a gaggle of refugees set out across the Atlantic Ocean in 'three forty-five-foot gaff-rigged schooners'. Franklin gives his orders:

Due east all the way. To the fabled lands of Europe. To a place where a white man can stand at last on his own two legs. Where he need not fear persecution. Where he need not fear slavery. Sail east, Admiral, until we discover a new and hopeful world - a world of freedom! ${ }^{43}$

In his famous paper 'The Significance of the Frontier in American History' (1893), the historian Frederick Jackson Turner professed that the first frontier 'was the Atlantic coast. It was the frontier of Europe', a contact zone of physical danger, hardship and the unknown. By venturing across the ocean and settling on the other side, the first European settlers began the long process of becoming Americans by virtue of the self-reliance and endeavour the environment called upon them to exhibit:

the frontier is the line of most rapid and effective Americanisation. The wilderness masters the colonist. It finds him a European in dress, industries, tools, modes of travel, and thought. It takes him from the railroad car and puts him in the birch canoe $[\ldots]$ He must accept the 
conditions which it furnishes, or perish [...] Moving westward, the frontier became more and more American. ${ }^{44}$

At the end of 'Eastward Ho!', the inverted nineteenth-century frontier has morphed into the earliest frontier constituted by the ocean. While they were not the first English-speaking settlers, the migrants known as the Pilgrims traversed this frontier in 1620 in pursuit of freedom of worship and the financial opportunities offered by American plantations and Native American trade. In the short story's symbolic structure, Franklin's destination point is a mythic space of security from persecution. Given Europe's history of religious and ethnic violence, evidenced in the decision of the 1620 Pilgrims to seek freedom of worship in North America, the continent's invocation at the end of Tenn's short story is an irony much deeper and more cutting of white supremacism than the obvious satire of the inverted frontier. The idea of Europe as a place of freedom and sanctuary is posed as a myth, a 'fabled land', and significantly the refugees do not arrive there during the narrative of the story. Indeed, one might conjecture they cannot reach this Europe, unless it is a different place from the Europe of the mid-twentieth century, whose history contradicts its interpretation as a continent free of persecution. Franklin's proclamation that in Europe 'a white man can stand at last on his own two legs' seems darkly comic, given that the continent's modern history of colonial exploitation staged white freedom against the slave-labour of Africans and their descendants. Turning a free and safe Europe into a myth may be the most powerful means by which 'Eastward Ho!' satirizes the supposed superiority of whiteness.

In Whitley Strieber and James W. Kunetka's novel Warday and the Journey Onward (1984), a fictional travelogue set in an America devastated by nuclear war, the British and the Japanese are aiding the reconstruction of the USA, and America has become dependent on these two former imperial adversaries. Further, two groups of people defeated during the USA's expansion west have re-asserted their entitlement to the land - Hispanic Americans and Native Americans. Covering large swathes of Texas and New Mexico, a Hispanic Free State bordering Mexico has declared its independence from the United States, calling itself Aztlan. In the 1960s and 1970s, Aztlán was a concept used by the Chicano Movement to celebrate and reclaim their heritage. In Nahuatl, Aztlán means the lands to the north', and it refers to the mythic point of origin of the Aztecs before they migrated south to their capital Tenochtitlán (where Mexico City now stands). Used to refer to the American South West geographically, Aztlán was projected as the homeland of Chicanos and it functioned as a political symbol of their indigenousness. ${ }^{45}$ In Warday, nuclear war rewrites the 
USA's acquisition of parts of Mexico during the 1845-48 War. The leader of Aztlan (spelt without an accent in Warday) reminds his audience of this as he defends the country against charges of separatism. Interpreting the USA's appropriation of Texas, New Mexico and California as 'theft' posits the emergence of Aztlan as an act of justice redressing a past crime committed by the United States. Consequently, the nuclear war that made its emergence possible is praised for correcting historical error: 'Of course, we are very sorry for all the death and suffering. But Warday also brought some good - our Aztlan.' Resistance to Aztlan as a distinct geohistorical entity belonging to Chicanos is apparent in Strieber's passive-aggressive narration (Strieber and Kunetka are characters in their own novel). Strieber seems reluctant to finalize the movement of history: 'This was their place, their time at last, and these their days of sunshine. ${ }^{46}$ The metaphor of the reclamation of Aztlan as 'days of sunshine' suggests that while Hispanic Americans and Native Americans rightfully inhabit this location at this moment in time, the weather will change and their 'time' will pass. In Warday, the frontier has swung against the United States by peoples previously defeated in battle. Nuclear war allows land previously seized in victory and incorporated into the American nation to be retaken, although the sly narration suggests Aztlan's occupation of the land is not final. This residual ambience of American patriotism lurks throughout Warday, and a social critique of the USA is more clearly enunciated in 'Eastward Ho!' and 'Saint Janis'.

\section{In Darkest America}

Several generic markers situate 'The Feast of Saint Janis' as a post-nuclearwar fiction: mutated radiation victims (a marginalized group known as the jennie-deafs), a limited and strictly rationed electricity supply, previously densely populated locations transformed into dangerous no-go areas and a capitalized euphemism for World War Three and its aftermath, 'the Collapse'. Washington DC lies in 'ruins', ${ }^{47}$ symbolizing the absence of central government. Nuclear war has rewritten international relations of power: the character Wolfgang Hans Mbikana (Wolf) has travelled to the American East Coast from New Africa in a position of privilege. The future New Africa is economically and technologically ascendant and taking advantage of the dilapidated USA whose political being is regionally fragmented and whose public health is precarious. The iconography and myths of European colonialism are invoked and inverted, so that traits the European empires projected onto colonized subjects are used to depict Americans: public pandemonium, flawed command of standard English, 
the heat of the colonies, lack of civility, squalor, immaturity, racial degeneration and the ignorance of indigenous peoples in the present compared to the monuments of human achievement lying in their past.

By using Wolf as focal point, the reader shares the New African traveller's alienation in America, and the feeling that 'home' is located far from here. As the reader follows Wolf's impressions of Baltimore's docks, the USA is strikingly unhomely:

the rick-a-rack of commercial buildings crowded against the waterfront. The clatter of hand-drawn carts mingled with a mélange of exotic cries and shouts, the alien music of a dozen American dialects. Workers, clad in coveralls most of them, swarmed about, grunting and cursing in exasperation when an iron wheel lurched in a muddy pothole. Yet there was something furtive and covert about them, as if they were hiding an ancient secret. ${ }^{48}$

One is reminded of Edward Said's Orientalism (1978), which outlines how the history of the West's scholarly, administrative and creative writing about 'the Orient' took on a critical mass ensuring that making a statement on the Orient could only take place if that statement's verisimilitude satisfactorily fitted into the existing body of thought. One consequence of this weight of credibility is that Orientalism spoke for the people of the Orient because they lacked the material power and resources to enter Orientalist discourse and speak for themselves. Said suggests that in representing the people of the Orient, Orientalists would repeatedly construct an image of the Orient that buttressed the West's self-image as superior and civilized. Orientals appeared as unscrupulous, despotic, inscrutable, sensual and cruel, and against those qualities Westerners appeared fair, democratic, honest, chaste and kind..$^{49}$ Orientalism is a seminal building block of postcolonial studies, but it has been subject to various qualifications, revisions and oppositions..$^{50}$ One of its strongest ideas, however, and arguably the least contested, is that the West's ability and will to exert its representation of the Orient is the cultural expression of the material practices of colonialism and imperialism. Wolf's perception of the United States bears close affinities to the Orientalist images that European colonial administrators, scholars, soldiers and writers constructed, particularly the images of the British rule in India. The British Empire's India was characterized by squalor, chaos and the enigmatic quality of Indian society - for Wolf, America's disorder poses an 'ancient secret', a question to be solved, presumably by their colonizers. Wolf's impressions register the disorder around him, using 'clatter' and 'rick-a-rack' to convey onomatopoeically the surrounding noise. The mosaic of languages spoken keeps Wolf at a 
distance - his observation never becomes empathy. Tellingly, the narrative refers to the Americans as 'natives', ${ }^{51}$ a term which carries the pejorative associations of underdevelopment and inferiority. Another seminal text in postcolonial studies is the reading of Joseph Conrad's novel Heart of Darkness (serialized in 1899) performed by Nigerian novelist and critic Chinua Achebe, who protested against Conrad's novel's canonical centrality on the grounds of its racist representation of Africans. One of Achebe's criticisms of Heart of Darkness is the demeaning language Conrad puts into the mouths of black characters (on the rare occasion they speak), implying their idiocy through their flawed command of English. Achebe sums this up by writing 'Language is too grand for these chaps; let's give them dialects! $!^{52}$ - exactly how the workers on Baltimore's docks are described speaking. Wolf travels as a representative of the Southwest Africa Trade Company (whose similarity in name to the East India Company that opened India up to British trade extends the aforementioned points of congruence). Chiming with the stereotypes of the British Raj, the New African foreign service administrators in America universally drink 'ginand-tonic'. The heat of the USA is stressed, 'sweltering' and 'oppressive' during the middle of day, ${ }^{53}$ echoing the warnings against exposure to the midday sun in Britain's tropical colonies; this was observed by the Indianborn writer Rudyard Kipling and recorded in song by Noël Coward, whose lyrics used the heat to satirize English stubbornness: 'mad dogs and Englishmen / Go out in the midday sun'. ${ }^{54}$

Wolf's mission leads him to negotiate with Charles DiStephano, Comptroller for Northeast Regional, de facto ruler of the upper East Coast of America and the epitome of the lack of civility the New Africans detest in Americans. DiStephano is difficult, dissembling, and 'Wolf was disconcerted. He was used to a more civilized, a more leisurely manner of doing business.' On learning that Wolf has to travel to Boston for DiStephano's decision on the Company's proposal, his fellow New African Ajuji sneers, 'That's exactly the sort of treatment one comes to expect from these savages.' A financial failure back in New Africa, her bruised sense of self is rebuilt by distancing the Americans as subhuman. Many New African colonial officials find the American manner brutish, although Ajuji's prejudices are the most keenly developed: '["]These - Yanks", she hissed the word to emphasize its filthiness, "live in squalor. Their streets are filthy, their cities are filthy, and even the ones who aren't rotten with genetic disease are filthy. A child can be taught to clean up after itself. What does that make them?"'55 Ajuji links the dirtiness of colonized peoples to their lack of maturity. This imperial trope of infantilization made paternal colonial intervention seem right - Kipling's framing of colonized people was 
'Half-devil and half-child' ${ }^{56}$

A similar mix of abject foulness and immaturity characterizes the Native Americans' assumptions about white America in 'Eastward Ho!' Various historical stereotypes surrounding Native Americans are attached to the beleaguered white Americans. The white Americans cannot speak, read or write standard English; they are superstitious and particularly susceptible to the effects of alcoholic beverages; their social organization is feudal and leadership roles pass along hereditary lines. These 'romantic children'57 elegize about their traditions in hopeless notes, that their United States was once as great as the vigorous Native American nations, appropriating the speech of the elder Tamenund at the close of The Last of the Mohicans, who lamented the "palefaces are masters of the earth, and the time of the Red Men has not yet come again'. ${ }^{58}$ Sarah Calvin, the daughter of the Supreme Court Chief Justice, has been living with the Sioux as an official hostage. As well as wearing Native-American robes and braiding her hair in a fashionable Sioux style, Calvin has tried to dye the colour of her skin. She does not want to return to the white USA and swears at Franklin, 'Filthy paleface! Foul, ugly, stinking whiteskins! I'm an Indian, can't you see I'm an Indian? My skin isn't white - it's brown, brown!'59 Having internalized the Native American estimation of white culture, she physically fights to pass as 'brown' instead of accepting an identity as white, which she associates with humiliating filth.

Wolf meets his fellow Africans in a Baltimore version of a European colonial club: 'The Uhuru Club was ablaze with light by the time he wandered in, a beacon in a dark city. Its frequenters, after all, were all African foreign service, with a few commercial reps such as himself forced in by the insular nature of American society, and the need for polite conversation.' The colour codes of the narration construct the Uhuru Club as a place of enlightenment holding out against the swarming blackness of American society. The light of New African colonialism is also the light of learning shining the way through the American night. Some debate takes place between the New Africans about whether the USA used to be technologically advanced, registering the familiar ambivalence about the usefulness of America's achievements in warfare and space exploration. When one New African defends Americans as 'hardly savages' because 'before the Collapse they put men on the moon', he gets this reply from Ajuji: 'Technology! Hard-core technology, that's all it was, of a piece with the kind that almost destroyed us all. If you want a measure of a people, you look at how they live.' For Ajuji, technology does not measure out a people's level of civilization. Social habitat defines 'a measure of a people', although her standards appear snobbish by overlooking economic mate- 
rial conditions in favour of seeing American decrepitude as a cultural propensity towards squalor. The faded grandeur of 'rusting refinery buildings' in Philadelphia signifies the power that the United States once wielded; the buildings rise 'to the sky forever in tragic magnificence' ${ }^{60}$ The 'tragic' quality of the refinery testifies to the nation's squandered potential, in which labour and capital were directed into nuclear weapons that, as Ajuji protests, nearly eradicated life from the planet. To see America's fate via the claims of tragedy is to see its lowly future as the appropriate repercussion of its military hubris. American autonomy seems dubious and Philadelphia, home of the Continental Congress that adopted the Declaration of Independence, lies decrepit.

The dénouement of 'Saint Janis' reveals the savagery of post-nuclearwar America in a spectacle of sexual violence. White Americans are discovered to be savages regulated by crude social ritual and manipulated by politicians, and the text reflects this critique back on twentieth-century America. In 'Saint Janis', the character of Maggie has volunteered to go on a music tour culminating in Boston, with her appearance and voice surgically altered so she resembles Janis Joplin, the lead singer of the countercultural California-based rock group Big Brother and the Holding Company. As the title suggests, Joplin (who died in 1970 of a heroin overdose) has special status in the collective imagination of the future. The tour (and Wolf's observation of it) is organized by the government, and the drug-taking star persona of Joplin officially represents the United States: 'Janis Joplin, our famous national singer' ${ }^{61}$ As Joplin, Maggie's performance on stage 'roused the audiences to a frenzy'; ${ }^{62}$ on the final date of the tour on Boston Common, she provokes a sexual fury in the participants so strong the crowd murder her. During the performance couples start having sex and small fires are started: 'the lights and the bestial noise of the revelers combined to create the feel of a Witch's Sabbath'. A pagan ritual has begun and the people are swallowed by primal urges, connected by figurative language to the natural force of flowing water: 'the crowd roared and surged forward. An ocean of humanity converged on the stage, smashing through the police lines, climbing up on the wooden platform.' During the violence, Hawk, one of the lighting crew, offers Wolf official and unofficial justifications. Officially, the 'social engineers and their machines' believe the base urges the Joplin ritual unleashes will raise the birth rate and stop America's population dwindling. Hawk's subsequent gesture undermines the official justification and resituates the ritual as an exercise in keeping power: 'he spat over the edge of the platform. "Ahhhh, why should I spout their lies for them? It's just bread and circuses is all, just a goddamned release for the masses."' Maggie dies, so the government 
is not the focus of the populace's wrath, and that end is desperately brutal as the crowd waves about the 'shreds of Maggie's dress'. Cueing readers to see the ritual murder as a comment on late-twentieth-century America (and possibly a conservative warning that the emancipatory energies of the counterculture would result in social disorder), before the violence begins Wolf comments, 'This must be how America was all the time before the Collapse.' Hawk's comment, 'This is a sick country', ${ }^{63}$ is a medical and a moral diagnosis on the America of 1980.

DiStephano is perfectly frank: there have been 22 versions of 'Janis' since the Collapse, and Maggie volunteered to play Janis knowing her predecessors had been massacred. The government-sponsored tour is a barometer of the national emotional climate:

'Every year Janis offers herself to the crowd. And every year they tear her apart. A sane woman would not make the offer; a sane people would not respond in that fashion. I'll know that my country is on the road to recovery come the day that Janis lives to make a second tour.' [DiStephano] paused. 'Or the day we can't find a woman willing to play the role, knowing how it ends.'

DiStephano does not rationalize the violence in the name of encouraging the birth rate. It is purely the attempt to channel the insanity of a poor, dying people and the individuals amongst them who crave 'fame and glory' ${ }^{64}$ The willingness to exchange one's life for fame literally is a grotesque distortion of the USA's star-making media networks. It is Janis who is to be consumed at her own feast.

DiStephano tells Wolf he was chosen to see this violence as a warning to the rising New Africa. The Comptroller believes the negotiator will 'certainly rise to a responsible position within the Southwest Africa Trade Company. Your decision will affect our economy [...] When that happens, I want you to understand one thing about our land: We have nothing to lose. ${ }^{65}$ One is put in mind of the 1970s American President who cultivated a reputation for irrationality and unpredictability in order to imply to North Vietnam that he was willing to fight with nuclear weapons. In a late 1970s book, one of President Nixon's top aides recounts Nixon in 1968 considering "what he called the "madman theory" if elected president. This entailed exploiting his reputation as a hard liner to frighten North Vietnam that he would launch a nuclear attack if it did not make peace. ${ }^{166}$ DiStephano's message to Wolf appears to be: make your future decisions in the USA's best economic interests because a people driven to insane rituals of sexual violence are psychologically willing for more war. 'Janis' portrays the American state as able to contemplate war with little difficulty 
given a collective obliviousness towards the value of the life of individual citizens.

\section{Declarations of Dependence}

In Warday and 'Janis', the USA is financially reliant on other nations in a form that could be called neocolonialism - just as US assistance around the world since 1945 has been criticized for encouraging forms of economic dependency that are neocolonial. ${ }^{67}$ This section understands these representations in terms of a global free market in which the strength of the American economy seemed challenged by the success of Japan and West Germany - two countries defeated by the Allies in World War Two and whose economic rebuilding afterwards was driven by the aid America 'poured on', as Warday reminds us. The memory of the Marshall Plan flashes up in this future because now is the time for the recipients of US aid to make good the moral balance. In several places, Britain's efforts to assist America after nuclear war are compared to the USA's entry into World War Two on the Allied side. In this frame of understanding, British aid is nothing less than what is expected. As a fictional teacher in Baldwin, Pennsylvania puts it, 'When it came time for [the British] to repay their debt for our help and support through two world wars, they didn't hesitate. ${ }^{68}$

During the 1970s and into the early 1980s, the American economy was experiencing high inflation and low employment. Every year 'between 1973 and 1981, the average income of employed workers, adjusted for inflation, fell by at least 2 percent'. America's heavy industries felt the strain, with the number of permanent jobs in the automobile industry declining from 940,000 to around 500,000 between 1978 and 1982, and the steel industry experienced a similar drop. ${ }^{69}$ The vulnerability of American workers was seen to be linked to Japanese imports, especially in automobile manufacture. In March 1981, the US Secretary of State and the Japanese Foreign Minister concurred that the state of the US automobile industry was not due to Japanese competition; nonetheless, the widespread perception in America 'held [Japan] as a culprit' and the two politicians felt this sentiment could feed calls for protectionist measures in Congress. ${ }^{70}$ Later that year, William E. Brock, US Trade Representative, drew President Reagan's attention to Japan's share of the US automobile and motorbike market (21 per cent and 65 per cent respectively). Brock highlights what he perceives as the unfairness of the Japanese state's curbs on certain imports: 'Japanese success in penetrating U.S. markets and the resulting U.S. trade deficit [...] have become serious political issues because 
Japan does not permit sufficient access to those of its markets in which the U.S. is competitive. ${ }^{71}$ Grassroots campaigns to 'Buy American' were launched by garment and automobile unions; job losses and 'declining sales of domestically made products' in the period have been attributed to increased foreign competition, US companies relocating production abroad, or 'buying parts or finished products from foreign manufacturers' ${ }^{72}$ Rather than fall equally on all Americans, industrial workers were heaviest hit, and the disparity between rich and poor grew in the 1980s.

The seeming unfairness of Japan's and West Germany's fiscal growth, which by the 1980s was read by many Americans as occurring at the expense of their domestic economy, seems to inform Warday and 'Saint Janis'. America's recovery after nuclear war is imagined to be handicapped because of the economic conditions attached to the assistance provided by other nations. These representations of Japan, Europe and New Africa's exploitation of a post-nuclear-war America reflect the resentment that countries whose poverty necessitated US aid have come to outstrip American economic power (in the cases of Japan and West Germany, at least). To borrow a recurrent symbol, in re-establishing its civilization, the frontier has been weighted unjustly against America by its economic competitors. The character Tevis in Warday, whose economic judgments are made credible by his profession as a university professor, complains, 'There will never be another United States as free, as powerful, as magnificent as there was before. From a statistical standpoint, we regressed too far. Now outsiders can control how much reconstruction we do of our technological base industries, and thus make sure we stay just far enough behind not to be a threat. ${ }^{73}$ By way of contrast, in Kim Stanley Robinson's novel The Wild Shore (1984), 'the fall of American civilization [is] partly deserved ${ }^{74}$ because the nuclear weapons the USA built threatened the species.

Given that Warday and 'Janis' depict dystopian societies being read in relation to the American economy and its social effects, it would be remiss not to acknowledge Tom Moylan's towering study Scraps of the Untainted Sky: Science Fiction, Utopia, Dystopia (2000). One feature of Moylan's book is a series of case studies of late-twentieth-century fictional dystopia. Noting the 'economic restructuring, political opportunism, and cultural implosion' in the USA and UK since the 1970s, Moylan interprets SF texts as forced to adopt the dystopia as a critical position because utopianism was colonized by the imaginary of advertising. He reads a series of critical dystopian texts as reworkings of the genre intended to fit the new 'economic, political, and cultural conditions' of the era, especially the sense that the global range of free market capitalism had created a closed circuit outside of which 
no space existed to step beyond the 'social reality' constituted by this economic system. However, perhaps because of their publication slightly before Moylan's case studies, neither text discussed here operates in the politically progressive ways identified by Moylan. 'Janis' lacks the 'radical hope' that would programme readers to see its future as avoidable or (if the story is interpreted as a veiled version of the USA in 1980) this present as improvable. Nonetheless, its vision is effective as a satire on the economic and social state of America. Warday seems closer to the 'fashionable temptation to despair in the early 1980s' Moylan sees subsequent trends in critical dystopia rejecting. ${ }^{75}$ At the end of this chapter it will be evident that Warday offers hope, but its confidence in American redemption is lodged in a particular group of citizens. Moreover, this hope is founded on a nostalgic return to American values - the desire for the nation to retrace its steps rather than break away from its historical trajectory.

The complexity and sophistication by which 'outsiders' manipulate the circuits of global capital to arrest American redevelopment in Warday are well conveyed. The Centers for Disease Control constitutes the largest nonmilitary US Government agency, and it

is heavily supported by the British. US tax collection procedures are still too minimal to guarantee the kind of budgetary consistency a massive operation like CDC requires. What the English do is simple: they pay CDC's salaries out of their general exchequer, then bill the US Federal Reserve bank in Atlanta, which transfers gold down at Fort Knox from the American pile to the British pile. ${ }^{76}$

The British provide medical aid to sick Americans and supply capital to generate growth in the economy, but various characters that Strieber and Kunetka meet think these are covert schemes to ensure the USA's abjection. The rhetoric of aid allows the British to occupy parts of North America militarily and the conditions attached to outside investment ensure the end of America's independence. The issue of dependence is key: the novel is vocal in seeing the nation becoming a colonial possession (curiously, Warday does not refer to the fact that the USA was once part of British North America). Tevis is a major advocate of this interpretation of UK aid:

look at the English. They're all over the place. Two thousand British bureaucrats are running this country through the blind of the Relief, which is really a colonial government disguised as a sort of Red Cross with teeth [...] You didn't see Belgium developing the Congo. [The undamaged powers] do not need our markets, they need our resources, and they will encourage American economic development 
just enough to get our agricultural system running on a stable base, and then they will put the brakes on. ${ }^{77}$

With specific reference to European colonialism, Tevis fears the US is being cultivated as an ancillary satellite of a new economic order centred on Japan and Europe.

Warday and 'Janis' register some Americans' frustration that the economic system the United States supported around the world had delivered such bitter rewards. The effects of economic downturn on the working class are symbolically enacted on the post-nuclear-war stage. Rather than see affluent Americans benefiting from this economic system, resentment is displaced onto visitors from other countries deemed to profit from American misfortune. To reinforce my reading of post-nuclear-war America as a figuration of national economic decline, recurrent images visually echo the postindustrial shift that began in the 1970s, such as when Hawk surveys the American landscape out of a train window on Maggie's tour. He 'stared moodily at the broken-windowed shells that were once factories and warehouses. "Look out there, pilgrim, that's my country," he said in a disgusted voice. "Or the corpse of it." ${ }^{78}$ The end of industry signifies the death of the country. After World War Three, one of the first-aid stations the British establish is 'in the showroom of a local Ford dealership', ${ }^{79}$ the British state usurping a major symbol of American industrial prestige. Strieber and Kunetka meet a strikingly obnoxious Canadian banker on a train, who poses as someone ensuring the flow of capital into the United States by making 'a market for persons wishing to buy and sell instruments of ownership in American plants and equipment, trademarks, patents, and proprietary secrets'. However, the labyrinthine financial machinations seem to leave US companies less financially robust than before: 'one can buy a complete set of plans for the Boeing 747, including all supporting documentation, wiring diagrams, and subordinate electronic equipment schematics, and the right to use them' ${ }^{80}$ Canada joins the international strip-mining of American companies' last few assets, namely its intellectual property. This seems like the liquidation of a company that has gone into receivership rather than meaningful assistance.

Reflecting on Fitzgerald's hailing of American power in the 1920s by its influence on the cut of 'Gentleman's clothes', which symbolize 'the power that man must hold and that passes from race to race', ${ }^{81}$ control over fashion resides with the British and Chicanos. Residents of Los Angeles can buy 'something called The Overseas Journal for British residents. It's all about [...] how to avoid the embarrassment of old-fashioned American hairstyles by going to local branches of chic London salons.' Similarly, the resurgence of the Chicano population in Aztlan drives the purchase of men's suits from 
London: 'These people were Aztlan's elite [...] Across the aisle from me sat a man in a magnificent suit, perhaps even a Savile Row creation. ${ }^{82}$

With the exception of the British, the Japanese are the nation involved most closely in American redevelopment in Warday. In Aztlan, the Japanese have sent medicine, road-repair teams, irrigation equipment, cars, a train and many soldiers. The cars Strieber and Kunetka see are predominantly Toyota and Nissan limousines, 'the modern hallmark of the Japanese businessman' ${ }^{83}$ While reflecting on the residual presence of the World War Two race hate between Japan and the USA, John W. Dower wrote of the 1980s that 'rising economic tensions between the two countries prompted the resurrection of crude racial images and invectives on both sides' ${ }^{84}$ One of those American images of the Japanese, as a threatening mass, seems relevant to the representations in Warday. 'Little Tokyo [...] now extends all the way to Sixth Street. It must be four times its prewar size. ${ }^{85}$ The character Tanaka, planning a new train line between LA and Oakland, exemplifies the way these narratives personalize economic disparity within America by having rich immigrants profiting from the economic collapse:

I've got my whole family here now. We bought a lovely house in Beverly Hills last year. Lovely house. Pola Negri used to live there. Or maybe Theda Bara, we're not sure. We are redoing the gardens and installing a complete computerised home security system. It's lots of fun, because such large houses are unobtainable in Japan. ${ }^{86}$

The Los Angeles of the future is soaking up overspill from overcrowded Japan, and - referring to the opportunities for construction in the USA Tanaka proclaims, 'A whole new world is being built in this country and it's starting with California. ${ }^{87}$ It is straightforward to read this 'new world' as one in which the USA has a decreasing economic stake, even in its own investment and property. The fate of that 'lovely house in Beverly Hills' functions in the novel's symbolic system as a synecdoche for the country - the change of ownership means its history of previous occupation is being forgotten. Further, this (national) space is being made more secure by its latest custodians, and one infers they will be more effective than the previous owners in using technology to maintain the sovereignty of the new space. They are safe-guarding it from without and transforming it within, and appropriately for the novel's issue with 'Japanization', the garden is being altered. The New World's status as a pastoral paradise - a garden - bringing forth plenitude has been hailed across the centuries; ${ }^{88}$ praising the fertility of the land west of the Appalachian mountain range, Massachusetts doctor and almanac writer Nathaniel Ames wrote in 1758 
that it had become 'the Garden of the World'. ${ }^{89}$ In this future the garden is in foreign hands and they are remaking it to their specifications. ${ }^{90}$

Tanaka's plan to modernize his expensive house using up-to-date security technology emblematizes contemporaneous trends in American urban space. Los Angeles in Warday exemplifies a process I conceive as follows: the social consequences of the deregulated market economy that the Reagan administration continued and extended led to even greater division of wealth, more endemic poverty and greater neglect of American urban centres. America's abandoned city centres provided the imaginative stage on which to pathologize and criminalize poverty (which also has a racial dimension), necessitating more authoritarian police powers to maintain order. In unravelling this marriage of economic liberalism and increasing encroachment of personal movement and civil liberties, I am building on the argument of David R. Bewley-Taylor:

It is no coincidence that [the emergence of gated communities] accelerated during a period dominated by free-market capitalism. As policies of the Reagan administration tilted wealth towards those who already had money and left city cores to decline, more people could afford to move to gated communities and lock themselves away from the poverty and crime of the inner city. ${ }^{91}$

Americans able to afford to move to the suburbs or gated communities participate in the impoverishment of US urban space, seen as crimehaunted and demanding ever more police action, with the LAPD utilizing helicopters with infrared cameras and the city-wide traffic monitoring CCTV - what Mike Davis calls 'Fortress L.A.' ${ }^{\prime 2}$ Bewley-Taylor notes the concurrence of Los Angeles leading the country in expanding and extending the aegis of the LAPD in an era in which manufacturing jobs in the city were being relocated overseas. ${ }^{93}$ As space in Los Angeles is privatized and militarized, as freedom of trade creates the social contexts in which freedom of movement, of assembly and of domicile are highly limited, Davis suggests that one particular genre of popular culture is attuned to this antimony: 'Hollywood's pop apocalypses and pulp science fiction have been more realistic, and politically perceptive [than contemporary urban theory] in representing the programmed hardening of the urban surface in the wake of the social polarizations of the Reagan era. ${ }^{94}$

Produced in 1984, I argue that the presence of foreign investors and aid workers becomes a way for Warday to dramatize the increasing climate of fear and authoritarian policing in US cities - in the novel, LA is a place of incessant police surveillance. Partly because of the novel's allegiance to deep-held notions of autonomous and inviolate American individualism, 
domestic authoritarianism is displaced onto a foreign presence whose exploitative capital represents the networks of multinational capitalism in which the USA is implanted and whose social consequences are driving heightened policing. Articulating this thatchwork of interconnections, however, sits uneasily with the novel's patriotism, and it understands the British intervention through an ideology that sees Britain in thrall to centralized structures of command. Visiting the British Relief in Dallas, Strieber says, 'I cannot help but be uneasy in this foreign-controlled enclave. Like most Americans, my trust in massive central governments is nil. I am uneasy around these British civil servants with their paramilitary pretensions ${ }^{\prime} .^{95}$ The British are intent on facilitating the flow of international capital to their own advantage and extending the state into every citizen's life: British Military Rule has intensified in 'areas where the population is in a state of confusion or upheaval, and the local authorities are not able to cope'. The reference to 'paramilitary pretensions' positions Britain's central government as authoritarian shading into fascist. For the Destructuralists in the novel, the British Relief seeks to establish draconian national structures: 'big government is big poison' ${ }^{96}$ Perceived to have a 'massive central government', the British in America function as shorthand for the interference in individual rights that rides shotgun with the social effects of the free market.

As noted above with the British Relief aid station in a Ford dealership, these texts articulate anxiety about America's place in the economic ecosystem through the circulation of brands. Characters being interviewed in Warday are repeatedly impressed by Strieber and Kunetka's Sanyo recorder and in California there is a much stronger Japanese influence than ever before $[\ldots]$ And there are cars: new Nissans [...] sporty Toyota Z-90s, Isuzus and Mitsubishis and the occasional Mercedes-Benz. There are also a few Fords' ${ }^{97}$ Appearing as an afterthought, the reference to 'a few Fords' makes US manufacture appear as an irrelevant species headed for extinction, at a time when the automobile workforce almost halved. If brands are a way for Warday to displace the contradictions of US capitalism into the invasion of foreign competitors, 'Janis' uses them to critique American consumerism. 'Janis' uses America's brands to argue that this nuclear-armed civilization in the twentieth century is as superstitious and irrational as those so-called primitive societies it has periodically defined itself against.

Some Americans are privileged in Swanwick's future; DiStephano's dress is of a familiar national type, 'the traditional suit and tie of American businessmen'. ${ }^{98}$ DiStephano is the United States government in that region, and the idea of a comptroller as ruler squarely aligns economics as 
the basis for political power. DiStephano embodies all that is vile about a political and economic elite, manipulating the masses while claiming to be sating the popular will and unashamed of displaying his absolute power. When Maggie's tour visits Providence, what bridges the superstitions of these post-apocalyptic Americans and the habits of their 1980 counterparts is presented on the terrain of ubiquitous brands:

They skirted an area where all the buildings had been torn down but one. It stood alone, with great gaping holes where plate-glass had been, and large non-functional arches on one side.

'It was a fast food building,' Hawk explained when Wolf asked. He sounded embarrassed.

'Why is it still standing?'

'Because there are ignorant and superstitious people everywhere,' Hawk muttered. ${ }^{99}$

Ignorance and superstition are the sole explanations Hawk can muster to account for the continuing existence of what presumably is a former McDonald's fast-food restaurant. In addition to signifying the yellow ' $\mathrm{M}$ ' of the McDonald's brand, the ornamental arches suggest the arches of a church. The building stands because the brand has taken on sacrosanct status. Bearing in mind Wolf's comment, 'This must be how America was all the time before the Collapse', Swanwick's presentation of the fast-food restaurant invites one to think about how it functions in our own time, and why customers consume food in McDonald's in their millions every day. Marx's outline of commodity fetishism will help us here:

the commodity-form, and the value-relation of the products of labour within which it appears, have absolutely no connection with the physical nature of the commodity and the material (dinglich) relations arising out of this. It is nothing but the definite social relation between men themselves which assumes here, for them, the fantastic form of a relation between things. ${ }^{100}$

It is irrelevant that the arches are 'non-functional' - their purpose lies not in their 'physical nature' but in making manifest the 'social relation between men'. As a commodity, the products sold by McDonald's take their value from the social meaning agreed upon and emotionally invested in them. The value of McDonald's products, assumed to be a value that distinguishes them from other fast-food products, is really a sublimation of the social value of the act of their consumption. Marx reaches for a suitable idiom to describe this commodity fetishism: 
In order, therefore, to find an analogy we must take flight into the misty realm of religion. There the products of the human brain appear as autonomous figures endowed with a life of their own, which enter into relations both with each other and with the human race. So it is in the world of commodities with the products of men's hands. ${ }^{101}$

The barbarism of post-apocalyptic USA lies in its unthinking fetishization of commodities, expressed in terms of desirable brands that seem to have 'a life of their own'. This life-force encircles and protects the fast-food restaurant. Swanwick literalizes the religiosity of fetishism and the valuation of these commodities beyond their intrinsic qualities, turning brands into the object of ritual. In a religious festival Wolf observes in Wilmington, a parade processes to the river: a priest, eight altar girls, 'twelve burly men carrying the flower-draped body of an ancient Cadillac', and then the faithful congregation. The 'car was placed in a hole in the ground, sprinkled with holy water, and set afire. [Wolf] asked the guide what story lay behind the ritual, and the boy shrugged. It was old, he was told, very very old. ${ }^{102}$ Christian worship is here corrupted and the significance of this ritual is a lost historical referent. Shared attitudes towards the passing of America's automobile brands are organized into a ritual that seems to be the only way these Americans can gain a semblance of collective control over their industrial decline. The social relations of (or the cessation of) production are displaced into the magical properties of the Cadillac, treated with a reverence befitting the 'life' invested in this prestigious automobile brand.

The main target of Swanwick's satire appears to be an economic system in which the uneven terrain of the global market allows one continent to exploit the resources and capital of another. Some of these uneven exchanges have been identified as colonialism or neocolonialism. In our current economic system, certain brands focus consumption practices in ways that defy logic - that could be called a magical aura - but are in fact the accretion of habit whose origins in the workings of consumer capitalism are often obscured to contemporaries just as the historical roots of the Wilmington parade are not clear to the participants. As the short story implies, the continuing cultural accreditation of brands such as Cadillac or McDonald's takes on a fetish quality that values them for their social function in the community, not the intrinsic use-value of the commodities themselves. The function of defining the self and community that religion once provided appears in 'Janis' to have been displaced by the collective value projected onto commodities, in light of which the USA's twentiethcentury capitalist practices appear to be as primitive as their post-apocalyptic equivalents. 


\section{American Regeneration}

'Eastward Ho!' uses a mode of expression that is satirical and ironic; in 'Janis' that mode is satirical and melancholic. In taking the least critical view of twentieth-century American society, Warday has the most to mourn after the USA's destruction, and it is largely the most despairing of the three, lacking even the energy of their social criticism. However, Strieber and Kunetka's novel, clinging to a belief in key American qualities, is riddled with that ideology Sharp identified in nuclear frontier fiction: white Americans will survive because the war will bring out their toughness, religious faith and ingenuity. Several characters in Warday believe adversity has left Americans leaner than before: T. K. Allerton of Savannah proclaims 'we've learned something about just how tough we can be if we've got to be' and General George Briggs states that the war has 'revealed toughness and gristle and fellow-feeling that we didn't even know we had'. Troublingly, the novel suggests that psychotherapy is a luxury most patients could manage to go without: 'the number of people in therapy has dropped by more than half [...] most of us work so hard we don't have time to be crazy'.

In Warday, Christian faith has been an engine of survival. Strieber and his family survived in a school attached to a church in New York and 'While the city died we prayed there.' ${ }^{103}$ One is reminded of the Puritan Captivity Narratives of the late seventeenth century, such as Mary Rowlandson's $A$ Narrative of the Captivity and Restoration of Mrs. Mary Rowlandson (1682), where through faith in the face of adversity the devout are led out of bondage and suffering. In Warday, this model can be applied to the nation itself, returned to Christian devotion in a time of violence because God has shown mercy in ensuring the survival of some. Several Americans share Strieber's confession, 'the prospect of death [...] brought me back once and for all to the Church'. The character of Reverend Michael Dougherty, Catholic Priest, notes that since Warday 'my parish has more than quadrupled in size'. ${ }^{104}$ The renewal of the USA as a practicing Christian country is expressive of the language of divine ordination that suffuses other representations of nuclear war survivors, such as Roger Corman's 1956 film Day the World Ended. Finally, as in 'Janis', in Warday the US remains in possession of scientific and technological knowledge. Tevis professes, 'we've kept our intellectual base intact. Our schools are still damn good.' The assertion that the production of knowledge can somehow float free from the material base that makes it possible suggests deep investment in the ideology of American ingenuity. At the school where the Strieber family find refuge, the 'school's science teacher, Mrs Dannay, had managed to rig up a thing 
called a Kearney Fallout Meter' out of a coffee can, some aluminium foil and crushed gypsum she dug out of the wall. This apparatus identified which areas had low enough levels of radiation in which to survive. ${ }^{105}$ Mrs Dannay's Fallout Meter fits an American tradition where scientific knowledge emerges out of the empirical negotiation of practical conundrums. Scientists like Franklin and Edison have been mythologized for heroic contributions to knowledge through individual effort, and Mrs Dannay is a similar entrant into the national pantheon of 'can-do' ingenuity.

In Warday, the greatness of America's devastated civilization lies not in its technology but in its people and the promise they represent. Travelling back to Dallas at the novel's end, Strieber has a feeling of 'America in us, the promise and the children. It is the common dream of gold - the golden valley, the golden door, the gold in the hills, the gold at the end of the rainbow.' A tension lies between the 'us' Strieber speaks for and the 'common dream' of America, though; by placing Hispanic Americans and Native Americans in the separatist state Aztlan, by substituting Japanese investors in place of Asian Americans and by depicting the disappearance of black Americans ('you see the worse emptiness in the black neighbourhoods') it seems when the novel speaks for ingenious and Christian American survivors those Americans are white by default. ${ }^{106}$ Seed contends that the novel 'repeatedly questions' national unity, something that we have seen plenty of evidence to justify, but in reaching out to the rump of America the narrative manages to find 'coherence' ${ }^{107}$ in the national spirit preserved through nuclear war and carried into the future.

The depictions in Warday, 'Eastward Ho!' and 'Janis' are unlike many other representations of American invasions. First, none of them use the USA's destruction in a future war as an alarm call for Americans to be more alert to the necessity of tightening its military and political apparatuses, and since the nineteenth century this clarion quality of future-war fiction has been pervasive. Second, none of these texts represents America's invaders as communists (or their occasional metaphoric understudies, extraterrestrials) - nuclear war reduces the USSR to depths of abjection worse than the USA. Third, these texts insist that after a nuclear war the savagery and underdevelopment that Americans will descend into undercuts the country's claims to represent a higher civilization. Or, as one New African visitor puts it in 'Janis', in misperceiving their advanced technology (which explicitly includes nuclear weapons) as civilization, Americans had been oblivious to how their practices of living together were utterly uncivilized. All three texts reinscribe the racialized verbal sleight-of-hand that when 'American' comes without a qualifying term it automatically refers to a white person of European descent, which the African-American 
novelist and critic Toni Morrison (amongst others) observes ${ }^{108}$ - even the New Africans' terminology in 'Janis' appears to conflate 'Americans' with 'whites', although some Americans in the story are black.

'Eastward Ho!', produced during the civil rights struggle, invites one to indict white American attitudes of superiority. 'The Feast of Saint Janis' and Warday are 1980s texts and the victimization of poor white Americans is connected to the economic colonization undertaken by nations professing to assist America's rebuilding. In these texts, American development is unfolding as fast as its patrons allow, and several characters sense the country is becoming a colonized subject of richer nations. Becoming the loser in the post-nuclear-war international capitalist marketplace fits the story America was telling itself about its economy (especially its manufacturing economy) in the period: these texts offer an easily digested and populist interpretation of American vulnerability. Swanwick reflects the complicity of American business in the rapacious forces of multinational capitalism and the attendant authoritarianism of that economic and social system. His story brings out the irrational social mechanics of consumer capitalism in the late twentieth century. Strieber and Kunetka's motivation is to protest America's nuclear weapons while pledging allegiance to the nation and its irreducible qualities. Heralding the renewed Christian faith compelled by the remaking of a (racialized) national community, Warday seems far closer to the nuclear frontier fiction paradigm discussed by Sharp than the more cynical short stories of Tenn and Swanwick.

\section{Notes}

1. F. Scott Fitzgerald, 'Echoes of the Jazz Age' (1931), in The Bodley Head Scott Fitzgerald (rev. edn, vol. III), Bodley Head, London (1965), p. 330.

2. Fitzgerald, 'Echoes of the Jazz Age', p. 330.

3. Hugh Brogan, The Penguin History of the USA (2nd edn), Penguin, London (2001), pp. 498-99.

4. Fitzgerald, 'Echoes of the Jazz Age', pp. 337-38.

5. Seed, 'Constructing America's Enemies', p. 64.

6. Rieder, Colonialism and the Emergence of Science Fiction, pp. 124-27.

7. Dyer, White, pp. 32-36; Ella Shohat, 'Imagining Terra Incognita: The Disciplinary Gaze of Empire', Public Culture, 3.2 (Spring 1991), pp. 41-70; Shohat and Stam, Unthinking Eurocentrism, p. 141.

8. Booker, Monsters, Mushroom Clouds, and the Cold War, p. 65.

9. Gary K. Wolfe, 'The Remaking of Zero: Beginning at the End', in Eric S. Rabkin, Martin H. Greenberg and Joseph D. Olander (eds), The End of the World, Southern Illinois University Press, Carbondale (1983), pp. 4-5, 11. See also Wyn Wachhorst, 'The Days After: Films on Nuclear Aftermath', in Carl B. Yoke (ed.), Phoenix from the Ashes: The Literature of the Remade World, Greenwood Press, 
Westport, CT (1987), p. 184; Sharp, Savage Perils, p. 96.

10. Clarke, Voices Prophesying War, p. 208.

11. Donna M. DeBlasio, 'Future Imperfect: Leigh Brackett's The Long Tomorrow', in Carl B. Yoke (ed.), Phoenix from the Ashes: The Literature of the Remade World, Greenwood Press, Westport, CT (1987), p. 101.

12. Joyce A. Evans, Celluloid Mushroom Clouds: Hollywood and the Atomic Bomb, Westview and Perseus, Oxford (1998), p. 175.

13. Kim Newman, Apocalypse Movies: End of the World Cinema, St Martin's Griffin, New York (1999), p. 191.

14. Mick Broderick, Nuclear Movies: A Critical Analysis and Filmography of International Feature Length Films Dealing with Experimentation, Aliens, Terrorism, Holocaust and Other Disaster Scenarios, 1914-1989, McFarland, Jefferson, NC (1991), p. xi.

15. David Seed, 'Mapping the Post-Nuclear Landscape', Foundation, 89 (Autumn 2003), p. 65. The frontier ethos of Heinlein's SF is also remarked upon by Martha A. Bartter, 'Nuclear Holocaust as Urban Renewal', Science Fiction Studies, 13.2 (July 1986), pp. 149, 154, and Patrick Parrinder, 'The Black Wave: Science and Social Consciousness in Modern SF' (1977), CritiFan, 2 (1979), p. 20.

16. Paul Brians, 'Nuclear War Fiction for Young Readers: A Commentary and Annotated Bibliography', in Philip John Davies (ed.), Science Fiction, Social Conflict and War, Manchester University Press, Manchester (1990), p. 142. See also Cooper, 'The Whiteness of the Bomb', p. 83. Other series in the survivalist genre are discussed in David Seed, American Science Fiction and the Cold War: Literature and Film, Edinburgh University Press, Edinburgh (1999), pp. 17677.

17. Kerslake, Science Fiction and Empire, pp. 76, 173-74; Seed, American Science Fiction and the Cold War, p. 185.

18. Margot A. Henrikson, Dr. Strangelove's America: Society and Culture in the Atomic Age, University of California Press, Berkeley (1997), p. 376.

19. Carl Abbott, 'Homesteading on the Extraterrestrial Frontier', Science Fiction Studies, 32.2 (July 2005), pp. 242-44.

20. Ray Bradbury's 1950 short-story cycle The Martian Chronicles is an SF text that combines planetary colonization and terrestrial nuclear war to critique the privileging of North American culture and the destruction of non-Western societies as a consequence of frontier expansion. In The Martian Chronicles, an alien race of Martians is wiped out by chicken pox brought by human explorers, with extended comparisons made to the deaths of Native Americans resulting from European contact. The human explorer Spender, desperate to spare Mars the despoilment of colonization (and, voiced aloud, the nuclear war that waits in Earth's future), begins murdering the other humans in his exploration party. When Spender is killed, the compassion shown towards him by Captain Wilder, who encourages the other men to 'think of Spender from time to time', indicates the text's ambivalence towards human (more specifically, EuropeanAmerican) civilization. Ray Bradbury, The Martian Chronicles (1950), Voyager and Harper, London (2008), pp. 83-84, 96, 105, 117.

21. Sharp, Savage Perils, pp. 171, 4. 
22. Poul Anderson [and F. N. Waldrop], 'Tomorrow's Children' (1947), in Walter M. Miller, Jr and Martin H. Greenberg (eds), Beyond Armageddon, University of Nebraska Press, Lincoln, NE (2006), pp. 166-69.

23. Gilroy, Against Race, p. 356.

24. Leslie Marmon Silko, Ceremony (1977), Penguin, Harmondsworth (1986), pp. 127, 132, 128, 246.

25. Washington Irving, A History of New York (1809), in History, Tales and Sketches, Library of America, New York (1983), pp. 422-24.

26. Franklin, War Stars, p. 65. See also Eric S. Rabkin, 'Introduction: Why Destroy the World?', in Eric S. Rabkin, Martin H. Greenberg and Joseph D. Olander (eds), The End of the World, Southern Illinois University Press, Carbondale (1983), p. ix. A more complicated reading of the critique of colonial arrogance in War of the Worlds is made in Rieder, Colonialism and the Emergence of Science Fiction, pp. 4-5, 132-35.

27. Denis Johnson, Fiskadoro (1985), HarperPerennial, New York (1995), pp. 47, 207, 3 .

28. Steve Wilson, The Lost Traveller, Macmillan, London (1976), pp. 14143, 197, 144 .

29. Martin Barker and Roger Sabin, The Lasting of the Mohicans: History of an American Myth, University Press of Mississippi, Jackson, MS (1996), p. 14.

30. Wilson, The Lost Traveller, pp. 112-25, 137, 240-41, 244, 155-57.

31. Wilson, The Lost Traveller, pp. 158, 108-109.

32. Barker and Sabin, The Lasting of the Mohicans, pp. 14, 28.

33. Joan I. Glazer, 'Nuclear Holocaust in Contemporary Children's Fiction: A Surprising Amount of Agreement', Children's Literature Association Quarterly, 11.2 (Summer 1986), p. 87. These homological oppositions feature in Silko's Ceremony. Betonie recounts an anti-Creation myth in which a Native American witch tells the story of 'white skin people' coming to America, a story that brings white people into being. These white people cannot see the life in the world, they fear it, and out of New Mexico rocks (presumably a reference to mined uranium) the white people 'will lay the final pattern [...] across the world I and explode everything' (pp. 132-38). Native American literary responses to nuclear technology (Ceremony included) are actually much more varied than the simple proposition that Native America communes with nature while white America rejects it and journeys towards nuclear annihilation. Wendy Rose writes tenderly of J. Robert Oppenheimer's moral purgatory in the poem 'Robert' (1985) and Ray A. Young Bear's 'A Drive to Lone Ranger' (1984) is coolly optimistic that the energy resources discovered on Native American reservations will regenerate the Black Eagle Child Nation's economic health. Further references for Native American nuclear representations up to the late 1980s can be found in Helen Jaskoski, 'Thinking Woman's Children and the Bomb', in Nancy Anisfield (ed.), The Nightmare Considered: Critical Essays on Nuclear War Literature, Bowling Green State University Popular Press, Bowling Green, OH (1991), pp. 160, 174 n. 1. See also Jane Caputi, 'The Heart of Knowledge: Nuclear Themes in Native American Thought and Literature', American Indian Culture and Research Journal, 16.4 (1992); Kyoko Matsunaga, 'Post-Apocalyptic Vision and Survivance: Nuclear Writings in Native America and Japan', 
PhD Dissertation, University of Nebraska-Lincoln (2006); and chapter 5 of Patrick B. Sharp, 'The White Man's Bomb: Race and Nuclear Apocalypse Narrative in American Culture', PhD Dissertation, University of California (1999).

34. Sharp, Savage Perils, pp. 176-79.

35. William Tenn, 'Eastward Ho!' (1958), in Walter M. Miller, Jr and Martin H. Greenberg (eds), Beyond Armageddon, University of Nebraska Press, Lincoln, NE (2006), pp. 280, 291.

36. Tenn, 'Eastward Ho!', p. 288.

37. Howard Zinn, A People's History of the United States, Longman, London (1980), p. 131.

38. Quoted in Frederick Turner, Beyond Geography: The Western Spirit against the Wilderness, Rutgers University Press, New Brunswick, NJ (1983), pp. 28283.

39. Tenn, 'Eastward Ho!', p. 282.

40. Mary Rowlandson, A Narrative of the Captivity and Restoration of Mrs. Mary Rowlandson (1682), in Nina Baym (gen. ed.), The Norton Anthology of American Literature (6th edn, vol. A), Norton, New York (2003), pp. 330-32.

41. Quoted in Stephen J. Whitfield, The Culture of the Cold War, The John Hopkins University Press, Baltimore, MD (1991), pp. 20-21.

42. Tenn, 'Eastward Ho!', p. 287.

43. Tenn, 'Eastward Ho!', p. 294.

44. Frederick Jackson Turner, 'The Significance of the Frontier in American History' (1893), in Martin Ridge (ed.), Frederick Jackson Turner: Wisconsin's Historian of the Frontier, Wisconsin State Historical Society, Madison (1986), pp. 27-28.

45. Lorena Oropeza, 'Antiwar Aztlán: The Chicano Movement Opposes U.S. Intervention in Vietnam', in Brenda Gayle Plummer (ed.), Window on Freedom: Race, Civil Rights, and Foreign Affairs 1945-1988, University of North Carolina Press, Chapel Hill (2003), p. 213.

46. Whitley Strieber and David W. Kunetka, Warday (1984), Coronet and Hodder and Stoughton, Sevenoaks, Kent (1985), pp. 112-13, 120.

47. Michael Swanwick, 'The Feast of Saint Janis' (1980), in Walter M. Miller, Jr and Martin H. Greenberg (eds), Beyond Armageddon, University of Nebraska Press, Lincoln, NE (2006), pp. 318, 296.

48. Swanwick, 'The Feast of Saint Janis', p. 296.

49. Edward W. Said, Orientalism (rev. edn), Penguin, Harmondsworth (1995), pp. 6, 3-4, 38-39.

50. See David Cannadine, Ornamentalism: How the British Saw Their Empire, Allen Lane, London (2001); Robert Irwin, For Lust of Knowing: The Orientalists and Their Enemies, Allen Lane, London (2006); Lisa Lowe, Critical Terrains: French and British Orientalisms, Cornell University Press, Ithaca, NY (1991); Ian Buruma and Avishai Margalit, Occidentalism: A Short History of Anti-Westernism, Atlantic Books, London (2004).

51. Swanwick, 'The Feast of Saint Janis', p. 296.

52. Chinua Achebe, 'An Image of Africa: Racism in Conrad's Heart of Darkness' (1977), in Joseph Conrad, Heart of Darkness (3rd edn), ed. Robert Kimbrough, Norton, New York (1988), pp. 255-56, 262. See also Frantz Fanon, 
Black Skin, White Masks (1952), transl. Charles Lam Markmann, MacGibbon \& Kee, London (1968), pp. 17-40.

53. Swanwick, 'The Feast of Saint Janis', pp. 304, 299.

54. Rudyard Kipling, 'Thrown Away', in idem, Plain Tales from the Hills (1890), Macmillan, London (1900), p. 16; Noël Coward, 'Mad Dogs and Englishmen' (1934), in Chris Brooks and Peter Faulkner (eds), The White Man's Burdens: An Anthology of British Poetry of the Empire, University of Exeter Press, Exeter (1996), p. 363.

55. Swanwick, 'The Feast of Saint Janis', pp. 298, 304.

56. Vincente L. Rafael, 'White Love: Surveillance and Resistance in the US Colonization of the Philippines', in Amy Kaplan and Donald Pease (eds), Cultures of United States Imperialism, Duke University Press, Durham (1993), p. 185; Michael Paul Rogin, Ronald Reagan, the Movie, University of California Press, Berkeley (1987), p. 151; Shohat and Stam, Unthinking Eurocentrism, p. 140; Rudyard, Kipling, 'The White Man's Burden' (1898), in Chris Brooks and Peter Faulkner (eds), The White Man's Burdens: An Anthology of British Poetry of the Empire, University of Exeter Press, Exeter (1996), p. 307.

57. Tenn, 'Eastward Ho!', p. 286.

58. James Fenimore Cooper, The Last of the Mohicans (1826), Penguin, Harmondsworth (1994), p. 415.

59. Tenn, 'Eastward Ho!', p. 292.

60. Swanwick, 'The Feast of Saint Janis', pp. 303-304, 310.

61. Swanwick, 'The Feast of Saint Janis', p. 300.

62. Swanwick, 'The Feast of Saint Janis', p. 314.

63. Swanwick, 'The Feast of Saint Janis', pp. 318-22.

64. Swanwick, 'The Feast of Saint Janis', pp. 324, 306.

65. Swanwick, 'The Feast of Saint Janis', p. 325.

66. Iwan Morgan, Nixon, Arnold, London (2002), p. 107.

67. Anne McClintock, 'The Angel of Progress: Pitfalls of the Term "PostColonialism"', Social Text, 10.2 (1992), pp. 84-98.

68. Strieber and Kunetka, Warday, pp. 208, 219, 333.

69. Joshua B. Freeman, 'Labor during the American Century: Work, Workers, and Unions Since 1945', in Jean-Christophe Agnew and Roy Rosenzweig (eds), A Companion to Post-1945 America (2002), Blackwell, Oxford (2006), p. 203.

70. Alexander Haig et al., 'Memo of Conversation with Japan on General Foreign Policy, Automobiles, Defense, and North South' (23 Mar. 1981), available at National Security Archive, George Washington University, http://www.gwu.edu/ nsarchiv/NSAEBB/NSAEBB175/japan2-04.pdf (last accessed July 2009).

71. William E. Brock, 'Memo to President Reagan on Japanese Trade Barriers' (18 Dec. 1981), available at National Security Archive, George Washington University, http://www.gwu.edu/ nsarchiv/NSAEBB/NSAEBB 175/japan2-06.pdf (last accessed July 2009).

72. Freeman, 'Labor during the American Century', p. 203.

73. Strieber and Kunetka, Warday, pp. 214-15.

74. Brians, 'Nuclear War Fiction for Young Readers', p. 141. 
75. Tom Moylan, Scraps of the Untainted Sky: Science Fiction, Utopia, Dystopia, Westview Press, Oxford (2000), pp. 184-87, 195.

76. Strieber and Kunetka, Warday, pp. 50-51.

77. Strieber and Kunetka, Warday, pp. 215-16.

78. Swanwick, 'The Feast of Saint Janis', p. 309.

79. Strieber and Kunetka, Warday, p. 63.

80. Strieber and Kunetka, Warday, p. 313.

81. Fitzgerald, 'Echoes of the Jazz Age', p. 330.

82. Strieber and Kunetka, Warday, pp. 227, 122-23.

83. Strieber and Kunetka, Warday, pp. 108-109, 113-14, 123.

84. Dower, War without Mercy, p. 14.

85. Strieber and Kunetka, Warday, p. 153.

86. Strieber and Kunetka, Warday, p. 203.

87. Strieber and Kunetka, Warday, p. 203.

88. Robert Lawson-Peebles, American Literature before 1880, Pearson and Longman, Harlow (2003), pp. 51, 59-60, 110-11.

89. Nathaniel Ames, An Astronomical Diary: or, An Almanack for the Year of Our Lord Christ 1758, J. Draper, Boston (undated), pp. 15-16, quoted in LawsonPeebles, American Literature before 1880, p. 110.

90. By way of contrast, in James D. Forman's post-nuclear-war book Doomsday Plus Twelve (1984) Japan once again becomes a superpower and occupies the United States, but the occupation is a peaceful one. To enlist the reader into support for their presence, Doomsday Plus Twelve's plot tracks a young girl's crusade to prevent the citizens of San Diego taking revenge on the Japanese (Brians, 'Nuclear War Fiction for Young Readers', p. 139).

91. David R. Bewley-Taylor, 'Watch This Space: Civil Liberties, Concept Wars and the Future of the Urban Fortress', Journal of American Studies, 40.2 (Aug. 2006), p. 247.

92. Mike Davis, City of Quartz (1990), Vintage, New York (1992), p. 221.

93. Bewley-Taylor, 'Watch This Space', p. 238.

94. Davis, City of Quartz, p. 223.

95. Strieber and Kunetka, Warday, p. 51.

96. Strieber and Kunetka, Warday, pp. 61, 160.

97. Strieber and Kunetka, Warday, pp. 52, 152-53.

98. Swanwick, 'The Feast of Saint Janis', p. 297.

99. Swanwick, 'The Feast of Saint Janis', p. 317.

100. Karl Marx, Capital (vol. I), transl. Ben Fowkes, Penguin and New Left Review, Harmondsworth (1976), pp. 164-65.

101. Marx, Capital, pp. 164-65.

102. Swanwick, 'The Feast of Saint Janis', pp. 310-11.

103. Strieber and Kunetka, Warday, pp. 406, 356, 319, 25.

104. Strieber and Kunetka, Warday, pp. 33, 164.

105. Strieber and Kunetka, Warday, pp. 223, 31-32.

106. Strieber and Kunetka, Warday, pp. 397, 304.

107. Seed, 'Mapping the Post-Nuclear Landscape', p. 72.

108. Toni Morrison, Playing in the Dark: Whiteness and the Literary Imagination, Harvard University Press, Cambridge, MA (1992), p. 47. 


\title{
3 Soft Places and
}

\section{Mad Max Beyond Thunderdome}

\begin{abstract}
It is the West that is responsible [...] for violence, terror and permanent aggression directed against life. It has generalized and globalized violence - and forged the global level itself through that violence. Space [...] is both the weapon and the sign of this struggle.

Henri Lefebvre ${ }^{1}$

Atomic energy is to us what the Atlantic Ocean was to Columbus when he sailed from Spain. [...] Who can tell where our voyages into this unknown realm will lead?
\end{abstract}

Harold Wolfe ${ }^{2}$

Several depictions of the world after nuclear war are situated in Australia and the Pacific, and this chapter closely analyses the colonial and postcolonial politics of one such depiction in detail. Seminal post-nuclear-war text On the Beach (novel 1957; film 1959) is set in the region, as are short stories by Martin Amis and J. G. Ballard, the comic Tank Girl (1990; film 1995), and a section of Julian Barnes's A History of the World in $101 / 2$ Chapters (1989) (in some of these texts the psychosis of focalizing characters makes actual locations and historical events uncertain). Novels such as Aldous Huxley's Ape and Essence (1949) and Philip Wylie's Triumph (1963) see Australia and New Zealand as privileged sites of survival - their location is deemed to offer a greater chance of avoiding the fallout generated by a Third World War. Another factor influencing this tradition of representation is that nuclear bomb tests took place in Australia and the Pacific, including American tests in the Marshall Islands and British tests at Maralinga in the Australian Western Desert. ${ }^{3}$

More pertinently, this chapter argues that this recurrent feature of nuclear representations is also determined by a specific image of the Outback emerging from a colonial tradition of representation, an image of recalcitrant emptiness foreshadowing the ordering of cartography. The trope of seeing the Australian desert as an empty and indecipherable 'soft place' is a feature of the film Mad Max Beyond Thunderdome (1985; also known as Mad Max III), directed by George Ogilvie and George Miller; this 
chapter unpicks the complex relationship between post-nuclear-war landscape and colonial settlement in this American-Australian co-production.

The post-nuclear-war landscape and narrative of the film is influenced by at least two cultural forces, namely the history of colonial representation and the pleasure that SF and related genres offer in fulfilling expectations of character development. Further, the traditional mode of representing lands pre-existent to settlement carries ambivalence at its heart, and Beyond Thunderdome, drawing on the colonial tradition to visualize the post-nuclear-war world, reproduces this ambivalence. The film's vision of the Outback stimulates a terrifying contemplation of its uncertain depths and nothingness as well as a sense of exhilaration that this blank canvas is the stage for feats of adventure where the hero masters the landscape. Significantly, the film confuses traditional colonial roles of gender and race, and in doing so it registers how contradictory and mutated those narratives of colonization have become. The final section of this chapter considers the generic factors that subdue the film's play with the colonial tradition, namely the importance of seeing Beyond Thunderdome as the final instalment in a trilogy across which Max's heroic persona evolves. This last section sees in the film the culmination of a popular archetypal trajectory developed in the first two films. This context goes some way to explain why the ambivalent postcolonial politics of Beyond Thunderdome slips into the background as the narrative builds to a conclusion: the completion of Max's reluctant heroic status requires the film's ambivalence towards the colonial tradition to disappear into the desert sand.

\section{Theorizing Soft Places}

In the graphic novel The Sandman: Fables and Reflections (1994), the writer Neil Gaiman describes the phenomenon of 'nothing' spaces resistant to cartographic inscription. These are called 'soft places' in the story of the same name, in which three characters from different points in history, lost in the deserts of Northwest China, meet in their dreams. The character from 1992 tells the other two,

Time at the edge of the Dreaming is softer than elsewhere, and here in the soft places it loops and whorls on itself. In the soft places where the border between dreams and reality is eroded, or has not yet formed $[\ldots]$ Here. In the soft places, where the geographies of dream intrude upon the real [...] There aren't many left in my time - this place is still soft. That's how come we can all be here together. In my day - that's 1992 - this part of the desert is known as Taklamakan. That's Turkik for 'If you go in, you won't come out again.' 
One of the other characters, Marco Polo, lost in the Desert of Lop, asks, 'This is...the soft place?' The 1992 character replies, 'Not the only one. There's a few thousand square miles of central Australia, a couple of Pacific Islands.' The location of the soft places at the end of the twentieth century connects them to nuclear-devastated landscapes: Taklamakan in Northwest China, the Australian desert and islands in the Pacific have all been sites of nuclear testing because of their isolation and relatively low populations. We learnt immediately earlier in Gaiman's story that the disappearance of the soft places is attributable to people like Marco Polo, since "The explorers, and the ones who came after you [...] froze the world into rigid patterns. ${ }^{4}$ This equates the idea of soft places to the space preceding colonization. If 'explorers, and the ones who came after you' are the vanguard of imperialism, then soft places are what necessarily precede the arrival of empire.

It is often in the interests of empires for the lands they covet to hover in an intermediary realm of reality. The ideology of a civilizing mission calls forth a suitable space in which it can unfold, and therefore soft places are desirable to colonizing nations as ideas and as locations in the world that are unmapped and thus unclaimed in European eyes. Soft places represent 'unsettled' land in two ways: not yet calm or stable, and uninhabited by people who are recognized as people in Eurocentric eyes - in other words, Europeans and their descendants. In this imperial mode, the inhabitants of soft places are unable to contribute to the body of European geographical knowledge that Marco Polo's exploration represents. The notion of soft places, while acknowledging and valuing the space that exists before its 'discovery' by colonists, offers a sentimentalized space where past and present meet in a site outside colonial history. Gaiman's informal theory of the soft place is the starting point to flesh out the colonial tradition's construction of unsettled territory and its influence on the re-establishment of civilization in Beyond Thunderdome.

Australia's 'unknown' interior facilitated the projection of many imagined alternative societies onto the country and its neighbours in the seventeenth and eighteenth centuries. These include Henry Neville's The Isle of Pines, or, A Late Discovery of a Fourth Island near Terra Australis Incognita (1668), Denis Vairasse's The History of the Sevarambians (1675-79), Gabriel de Foigny's A New Discovery of Terra Incognita Australis (1693) and Ambrose Philips's The Fortunate Shipwreck, or A Description of New Athens (1720). ${ }^{5}$ Thomas Burnet's The Theory of the Earth (1684) proposed Paradise was to be found in the Antipodes. ${ }^{6}$ Filling in the 'huge blanks on the Australian map' was the first priority of the British expeditions conducting the inland exploration of the continent. ' 'Mapmaking' and exploration served 'colo- 
nial plunder, for the vision and knowledge constituted by the map both preceded and legitimized the appropriation of territory. ${ }^{8}$ Mapping undiscovered territory is privileged in narratives of colonization as an act of bravery (daring to explore unfamiliar space) and a contribution to knowledge (recording what is supposedly unknown). ${ }^{9}$

The soft places that precede colonization are brought into being by the colonizing process, which must assume the lands it civilizes are empty, and that history begins there with the arrival of Europeans:

From the Eurocentric view of the world, to which most Australians adhere, Australia was 'empty' until 1788 [...] Terra Incognita [...] For the first settlers the Aborigines did not count [...] in European eyes, the land lay open for the taking, and like the Aborigine it needed redeeming, civilising and colonizing. ${ }^{10}$

The European empires understood being-in-time as differentiated across race and place, with Western Europe privileged as the place where humankind's journey through history was furthest advanced. For the nations and peoples in the world yet to be incorporated into the trajectory of European modernity, entry into history had not commenced. ${ }^{11}$ The ethnocentrism of such historical models is confirmed by the absence of a sensibility of being-in-history amongst the Australian Aboriginal peoples whom the European empires considered belonging to a primordial past. ${ }^{12}$ Another reason to read the Outback as a soft place exiled from the course of history is the irreconcilable epistemological gap between the conceptual mapping of Aboriginal song-lines and their notion of a fluid creation-time (the Dreaming), and European habits of temporal and spatial being. In his book Experiences of a Colonist Forty Years Ago (1880), Australian George Hamilton proclaims, 'Here was a country without a geography, and a race of men without a history. ${ }^{13}$

This chapter began by listing some nuclear representations staged in Oceania, and this can be related to the region's perceived status as the last discovered area of the world, geographically and temporally marginal to modernity and yet to enter world history until European explorers arrive. 'The expansive energies of nineteenth-century capitalism brought about encounters between western powers and their "archaic" others, encounters which were managed by the theory of universally evolving time', writes Steven Connor:

Spatial distance was correlated regularly with temporal remoteness (thus the regular claim that the most geographically remote people of all, taking London and Greenwich Mean Time as a starting-point, 
the Australian aboriginals, were the most primitive, and therefore temporally as well as geographically antipodean). ${ }^{14}$

The New Oxford Dictionary of English records that the word 'Antipodes', which inhabitants of the northern hemisphere use in reference to Australia and New Zealand, has etymological roots in the late-Middle-English denotation 'inhabitants of opposite sides of the earth'; in the early seventeenth century, the word 'antipode' starts to be used to describe 'the direct opposite of something'. In Moby Dick (1851), the US novelist Herman Melville draws comparisons between America and Australia (both discovered relatively late by the 'enlightened world'), yet Australia remains more geographically distant: 'That great America on the other side of the sphere'. ${ }^{15}$ This oppositional status can be read in late-twentieth-century filmmaking, too. Imagining the Outback as a soft place was repeated in several Australian movies after the release of British director Nic Roeg's coming-of-age narrative Walkabout (1970), which presented Australia's national landscape as 'the ultimate blank slate'. Walkabout used the supposed backwardness of the Outback to critique the blandness of Western urban modernity by way of juxtaposition, positing the Australian desert as civilization's polar opposite. ${ }^{16}$

During the history of white settlement, this sense of Australia constituting the polarized other of early modern Europe infused the perception of the continent. Australia was meant to represent the state white Europeans had grown out of, a "natural" pre-European environment'. ${ }^{17}$ By corollary, cultural texts could easily slide the landscape into what the world will look like when humanity has almost wiped itself out. The title of Wim Wenders's millennial film Until the End of the World (1991) simultaneously suggests Australia's geographical marginality and the threat of World War Three that hovers over the actions of the characters. The film's dramatic crux depends upon the isolation of the characters, working in a laboratory inside the caves of the Australian Aboriginal Mbantuan people. With the radio giving 'nothing but static', the characters have no way of knowing whether or not nuclear war has broken out. This scenario only seems possible in the isolation of the Australian desert, with the Outback so peripheral to the rest of the world that one cannot be certain what is happening elsewhere. One could also speculate this location has been chosen for characters waiting to discover if nuclear war has started because it is already fitted out topographically for the post-nuclear-war world. At one point in Until the End of the World the desert horizon flattens into an absolute plateau, embodying the 'horizontality' Paul Carter identifies in The Road to Botany Bay (1987) as the 'distinguishing quality of Australian 
settlement'. ${ }^{18}$ This horizontality applies readily to recurrent images of the post-nuclear-war environment. The treacherousness of the desert in Beyond Thunderdome might be specifically related to the disenchantment experienced during the period of interior exploration. The very 'openness' and undifferentiated expanse of the soft place disrupted the colonizers' ability to write imperial settlement upon it. For the early Australian settlers, 'the endlessly receding natural boundary of the horizon' defied their ability 'to differentiate, to delimit and name in order to possess' ${ }^{19}$

So, traditions of colonial representation, with specific reference to the production of images of Australia during exploration and settlement, lend themselves to cultural producers imagining a world after nuclear war. The uncharted spaces lying in wait for European cartographers and the space of the world after nuclear war are positioned outside human civilization, either awaiting its imprint or the result of its self-destruction. ${ }^{20} \mathrm{I}$ am not intending to oversimplify the diversity of narratives and representations that make up the colonial tradition into a homogeneous monolith. I am referring to a colonial tradition of representation as a dynamic process, geographically and historically inflected, of generating certain icons and models of storytelling in the depiction of colonial exploration and imperial encounters. These icons and models are not universal and eternal but they are regularly repeated and, as I hope this chapter has started to illustrate, their repetition constructs the self-image of modern European imperialism as bringing colonized peoples into civilization and world history.

Apocalyptic future wars are a convenient narrative device in many Anglophone SF texts: having eradicated itself, the project of rebuilding white Western civilization borrows a hue of adventurism from frontier and colonial narratives. Like their influences, narratives of resettlement after nuclear war regularly privileged white male heroes; through their authority, resourcefulness and self-sufficiency the survival of their families and communities are made possible. ${ }^{21}$ This collusion between imperial adventure, heroism and white masculine authority is reorganized in Beyond Thunderdome.

\section{Post-Nuclear-War Colonization in Mad Max Beyond Thunderdome}

On first glance, there is much to connect the representation of the environment in Beyond Thunderdome to the colonial tradition. At one point the protagonist Max is bound and exiled into the desert on a donkey. The screen is filled by utter whiteness, and during a sandstorm, the donkey is sucked into a sand ridge. The Outback is projected as a place of shifting 
sands where the distinction between sky and sand is impossible, a treacherous place threatening to engulf wanderers, a paradigmatic soft place. The tribe of children that rescue Max call the Outback 'the nothing', and they rarely venture into it for fear of being 'swallowed by the sand'. In articulating their 'dread that the unknown might literally rise up and devour the intruder whole', the children repeat the imperial fear of 'blank spaces on colonial maps'.22

Landscape writer and cinema critic Ross Gibson suggests a complex relationship between the Mad Max trilogy, the Outback and the colonial tradition. On one level, the trilogy uses a future setting to rework a historical story of heroism and Australian national pride, the story of how the settlers' success in colonizing an extraordinary, inhuman landscape demanded and produced a remarkable people. However, the overriding impression from Gibson is that the environment in the trilogy is working 'fantastically' because by the 1980s Australian cinema audiences were no longer defining their national identity by the landscape. Filmmakers were free to take liberties with its history of representation and adopted a selfdeprecating view of Australia's environment and the myths it had generated. ${ }^{23}$ The colonial tradition remains a potent influence on Beyond Thunderdome, and it is not only being used in a distanced way. Australian cinema audiences in the 1980s may have stopped embedding their collective identity in the landscape, but as commodities to be sold to audiences around the world these films continue to solicit an international perception of Australia in which natural habitat informs perception of its inhabitants. The success of Crocodile Dundee (1986) would suggest that a global audience for unreconstructed Australian stereotypes of place and people still existed and were extremely popular. Accordingly, several cultural influences jostle each other in Beyond Thunderdome's depiction of the Outback, from Australia and other national traditions.

With these qualifications, Gibson's reading of the trilogy as mocking the history of depicting the Australian landscape leads to some productive readings of Beyond Thunderdome, which exploits the rhetoric and imagery of nineteenth-century imperialism while inverting its racial dynamics. In an early scene, Bartertown is described by its creator, Aunty Entity, with the aggrandizing language of empire-building that effaces or denigrates the conditions it has overcome. She shows Max the city below and proclaims, 'All this I built. Where there was desert, now there's a town. Where there was robbery, now there is trade [...] civilization.' Aunty has constructed civilization in the desert of the post-nuclear-war world, but unlike the European colonial project, the creator is a black female. The character of Aunty is played by the African-American singer Tina Turner, who is often 
remembered for contributing the theme song 'We Don't Need Another Hero' to Beyond Thunderdome, which begins 'Out of the ruins / Out of the wreckage / Can't make the same mistake this time.'

The Bartertown that Aunty has built is an outpost of trade, sustenance and community, although an undercurrent of violence remains present, threatening to rupture the civil order. The civilization above ground depends upon the Underworld below, where pigs are farmed to collect the faeces needed to make the methane fuel Bartertown runs on. The Underworld is controlled by a midget (Master) who rides on the back of a colossus (Blaster), known together as Master Blaster; they represent a skilled, colonized proletariat that has achieved consciousness of their central role to the workings of civilization. Master Blaster knows that despite their foul subterranean working conditions, where life expectancy is only two to three years, they possess 'not shit, [but] energy!' A repository of symbols from the nineteenth-century colonial era is observable in Bartertown's iconography, especially images of the Orient: Max travels in a camel-driven buggy, Aunty has an Asian saxophonist, and there appears to be a Bartertown Bazaar with people wearing conical hats. In this melange of imagery, the exoticism of empire is resurrected, although the encounters on Bartertown's crowded streets take place without racial or cultural segregation. Indeed, one might argue that the city's social hierarchies, where the racial codes of European imperialism seem meaningless, are as indebted to the multicultural centres of the postcolonial period as they are to nineteenthcentury colonialism. ${ }^{24}$ Contemporary Australian urban experience is characterized by the heterogeneousness Bartertown contains, and the conical hats and Asian saxophonist may reflect this unexceptional cultural and racial intermixture. In Beyond Thunderdome, the city that purports to represent civilization enshrines the coexistence of difference. Bartertown's streets enact the sense of multicultural conviviality celebrated by Paul Gilroy in After Empire: Melancholia or Convivial Culture? (2004), 'a mature response to diversity, plurality, and differentiation [...] orientated by routine, everyday exposure to difference' ${ }^{25}$ This touches on one of the issues facing 'minor national cinemas like Australia's': the perceived necessity to 'reproduce "ossified" stereotypes' as a way of exploiting Australia's international brand. Film scholar Tom O'Regan argues this strategy for promoting Australian film around the world elides the country's 'urban multicultural society' and serves 'the Anglo-Celtic hegemony and a unitary and consensual version of the nation'. ${ }^{26}$ Arguably, Beyond Thunderdome defuses this opposition by bringing the stereotypical desert-crossing itinerant (Max) into the multicultural community (Bartertown). As we shall see, the survival of the stereotype at the expense of the 'urban multicul- 
tural society' in the narrative is instructive about which cinematic brand was ultimately the stronger in 1985.

Despite Aunty's rule, her colonial project depends upon Master Blaster's labour power. The struggle between colonizing middle class and colonized working class is expressed in the film through the question, 'Who runs Bartertown?' When Max arrives, neither Aunty nor Master Blaster has asserted their authority over the other. Master Blaster enforces Aunty's reliance on their labour power by temporarily cutting off Bartertown's energy supply in order to coerce her into publicly stating, 'Master Blaster runs Bartertown.' Shapiro interprets Master Blaster as representing formerly colonized subjects coming to knowledge of their potential power by introducing the context of the 1973 oil crisis, when the Organization of Petroleum Exporting Countries (OPEC) 'cartel orchestrated its first embargo and dramatic price increase'. In the Mad Max trilogy, lack of petrol is the most significant factor contributing to social collapse, and fuel is the most valuable commodity in this post-apocalyptic future. Noting that 'until at least the mid-1980s, the [Western] oil-consuming countries remained fearful of further oil embargoes', Shapiro invites comparisons between OPEC's sanctions on oil and Master Blaster's demonstrative withdrawal of methane fuel. Because of their irreplaceable status in the production of Bartertown's energy, Master Blaster have become indispensable to the civilizing process. As they assert that centrality, potentially wresting control of Bartertown's civilization away from its architect, Aunty seeks to secure her leadership by reinforcing the restless subterranean workforce's subservience, but is handicapped by a seemingly typical dilemma for those who have assumed colonial authority. Aunty partly justifies the righteousness of her rule through her institution of criminal legislation (Aunty 'wrote the law'), but the law prevents her from using bare force to retake 'control of this new technocivilization'. ${ }^{27}$

Max supplies Aunty with the opportunity to break Master Blaster's power. Max arrives in Bartertown robbed of his transportation and belongings, and in return for Aunty's aid, Max agrees to challenge Blaster to a fight to the death in the gladiatorial arena called the Thunderdome. Max defeats Blaster, but because Max refuses to kill his opponent, Aunty punishes Max by exiling him to the desert on a donkey. Max is rescued by a tribe of white children who transport him by boat to their community built into the cliff face. The sanctuary offered by their village acts out the spatial dichotomy imagined during the nineteenth century, of the Australian bush divided between an inhabitable 'fertile coastal crescent' and 'the outback of the great inland plains'. ${ }^{28}$ As in Russell Hoban's novel Riddley Walker (1980), the tribe's language has begun to deteriorate. In the 
compression of socially degenerating whiteness and primitive imagery, the children reflect the cultural associations between convict and Aborigine:

Convicts who took to the woods [...] relied on the good will of the Aborigines for their survival. More than this, leaving the pale of order behind, convicts behaved like savages. In Botany Bay [...] convict and savage were fused into the figure of unreason. ${ }^{29}$

The children take the place of 'native' people: their records are the stories of their oral culture or cave paintings, they live in huts and they use spears as weapons. As with the Australian convicts, a preceding group of white inhabitants understood as savage, the children are exiled from the edifice of civilized order, although not by choice.

The children believe Max is the Captain Walker they have been waiting for to lead them to their homeland, although he refuses the role they want him to play. Frustrated by his aloofness, some of the children set out into the desert on their own, and Max feels obliged to retrieve them before they are consumed by the treacherous sands, or worse. When Max reaches them, they are close to Bartertown and without sufficient supplies for their journey back. Max leads the children in a covert raid into Bartertown's Underworld for provisions, where Aunty has had Master enslaved. In the course of their sortie, Max and the children kidnap Master, inadvertently sabotaging the Underworld so that Bartertown is destroyed in a series of explosions. Aunty pursues the rebels, and Max seemingly sacrifices himself so the children and Master can escape by aeroplane to the homeland the tribe have longed for, the ruins of one of Australia's bomb-ravaged cities.

It is certainly possible to read Beyond Thunderdome as a repellently racist film. By presenting whites as the subordinate colonized workers, their rebellion against the imperial overlord takes on a moral justification in a postcolonial era where European imperial dominions can no longer be celebrated as a source of pride. The film's triumph of colonized peoples against their oppressors strikes a politically acceptable note, while reversing the subjugated characters' expected gender and race means white masculine heroism can be valorized again. For Broderick, 'Max's phallic prowess easily defeats Aunty's matriarchal cunning. ${ }^{30}$ Brian McFarlane argues that co-director George Miller envisages this future through the eyes 'of white men', hence his neglect for the 'country's Aboriginal population and its history and a playing up of the Australian male's engagement with a demanding natural environment' ${ }^{31}$ Casting the film's primitive society as children confirms the immaturity of precolonial societies. ${ }^{32}$ The stagnating tribe lack a direction until Max arrives; Beyond Thunderdome effaces the Aborigine presence and repopulates the Outback with white children, 
ready to make their way in the world and grow up (literally as individuals and metaphorically as a society) now their Captain has discovered them (a rank that invokes the seafaring figures of European exploration).

Such an interpretation would be overly reductionist, ignoring the film's ambiguous relation to colonial and postcolonial contexts. In terms of its representations of civilization, Aunty's own complex characterization, and its status within the Mad Max trilogy, the film Beyond Thunderdome undermines the claims of colonization, imperialism and the civilizing mission. After all, Bartertown is based - literally - on 'pig shit'. The destruction of Bartertown as part of the film's narrative resolution reveals how precarious civilization is. The violence of the combat in the Thunderdome, and Max's refusal of the cruelty the dome demands, invites audiences to think about how Bartertown's civilization is inseparable from the violence at its foundation. Far from being the cornerstone of civilization, the law Aunty has written is not 'justly administered' but arbitrarily imposed, as embodied in the wheel of justice that randomly determines the nature of Max's punishment. ${ }^{33}$

Aunty Entity herself is a problematic figure, because her rule of Bartertown is not two-dimensional villainy, and she cannot be readily reduced to a simple colonial dominatrix. Film scholar Peter Fitting cautions against reading 'Tina Turner's character [...] as a breakthrough', ${ }^{34}$ but Aunty's courage and tenacity captures the audience's attention and defies reducing her to a stock type. Her construction of Bartertown is not the transplanting of a pre-existing culture into the Outback, but an act of self-definition for someone marginalized by her race and gender in the pre-apocalyptic world: 'Know who I was? Nobody? Except on the day after [World War Three]. I was still alive. This nobody had a chance to be somebody.' The phonetic slippage between Aunty Entity and 'Anti-Entity' reinforces her posture as a figure refusing to be governed by a destiny embodied in physical essence. In the pre-nuclear-war world, social forces interpreted that destiny as ontological absence ('Nobody'), but after the nuclear war Aunty's future is hers to shape alone. This tenacity is compelling to audiences, and her cultured appreciation of jazz contrasts favourably against Master Blaster's Underworld rule by terror. In its melange of peoples and colonial imagery, Aunty has constructed a town in which racial and cultural differences have become commonplace, redressing the structures of marginalization that subordinated her. At the film's end, with the children escaped and Max at her mercy, Aunty leaves him unharmed. She has learnt the worthy disinclination to kill a defenceless opponent that Max displayed in the Thunderdome. Her response to defeat is philosophical: 'Well, ain't we a pair, raggedy man. [Laughs] Goodbye, soldier.' Perhaps this reiterates 
Aunty's appreciation of the historical construction of the self. In accepting that they form some sort of dyad, she seems to recognize their dependency on each other for identity in metaphysical terms - the nomad needs the metropolitan to be the nomad, the civilized need the barbarian to be civilized. A similar recognition can be found in Angela Carter's postnuclear-war novel Heroes and Villains (1969), which stages an opposition between the nomadic Barbarian tribe led by Jewel and the communities of Professors and Soldiers who stand for civilization and the preservation of learning. The novel indicates that the Professors' civilization and the Barbarians' pagan culture reciprocate the identity of the other. One of the characters sneers at Jewel, 'You're not a human being at all, you're a metaphysical proposition. ${ }^{35}$

The star persona of Tina Turner and the songs she contributes to the soundtrack extend the complexities of embedding Aunty into a straightforward imperial dynamic. 'We Don't Need Another Hero' seems to jettison the value of heroic masculinity in a post-nuclear-war world, yet it endorses the moral compulsion Max heroically exhibits when he saves the children at the film's end. Theodore F. Sheckels also sees the song as a rejection of heroism, but I disagree with his interpretation of the song and Aunty's last words to Max. In Sheckels's reading, Aunty's meaning is that only the will to survive is relevant in this future. ${ }^{36}$ This seems erroneous: the lyrics, 'There's got to be something better out there / Love and compassion / That day is coming', praise Max for risking his life to enable the children's escape. In other words, individual survival should not and cannot be the philosophical foundation of existence. Another disjunction is between Tina Turner singing about the desirability of 'Love and compassion' while Aunty enforces her authority with the absolute violence of the Thunderdome. The complexity of the film's relation to colonial representations is manifest in Aunty, and Turner's star persona further complicates the character's status as villain. Aunty's power, confidence, charisma and narrative centrality make her very attractive to audiences, and after Max, she is the character in the film with whom audiences are most likely to share their allegiances.

\section{The Trajectory of Heroism in the Mad Max Trilogy}

Newman observes that the post-apocalyptic action genre the Mad Max trilogy belongs to demands 'colourful, larger-than-life Marvel Comics-style characters to strut their stuff in the ruins'37 (Gibson also notes the 'comicbook aesthetic'; ${ }^{38}$ another reviewer described the second film in the trilogy as a 'comic-book movie ${ }^{\prime 39}$ ). The contradictory imperial attitudes of Beyond 
Thunderdome interact with the evolution of Max's character across the three films, hailed as a hero but initially reticent to embrace such a role, in a manner reminiscent of Marvel Comics's protagonists. In the first film, Mad Max (1979), Max is considered the best law enforcement officer in the country, described in terms of DC Comics's trademark superhero: 'top superman'. Repeated claims are made on the lead character to fill the heroic role demanded by the lawless society of future Australia. As a lone antihero, at odds with both the enemies of order and the society he defends, Kim Newman compares Max to a 'doomed Western hero'. With a nod towards the frontier motif discussed in the previous chapter, the Mad Max trilogy is central in Newman's contention that 'the Western motif recurs throughout [the 1980s post-apocalyptic action] cycle' ${ }^{40}$ Jonathan Rayner identifies the landscape in Mad Max as the same blank desert of the American West and sees elements of the Western, SF, the biker movie and the police thriller in the first film. ${ }^{41}$ As well as the landscape, another Western ingredient is the Screw Jockeys, an archetypal criminal band riding into small towns and intimidating and attacking the inhabitants. The Mad Max trilogy exists between a specific colonial tradition of representing the Australian desert and the gravitational pull of commercially successful American genres. Like Bartertown's uncertain status in relation to postcolonial politics, it is starting to seem erroneous to fix an interpretation of the trilogy to a single nation or continent's history of representation.

The film Mad Max begins with gang member Nightrider being killed as Max chases him at high speed, and the narrative follows the actions of the Screw Jockeys (Nightrider's gang) as they take revenge. After the Screw Jockeys, led by Toecutter, burn Max's friend Jim Goose alive, Max resigns from the force. Fifi, his superior officer, sees Max as the hero who can restore order and bring the gang to justice:

FIFI: You're a winner, Max! [...] They say people don't believe in heroes any more. Well, damn them! You and me, Max! We're going to give them back their heroes!

MAX: Do you really expect me to go for that crap?

Max refuses to fight because it means irrevocably entering the savage world of the gangs: 'Any longer on that road and I'm one of them.' A sentimental orchestral soundtrack accompanies the "particularly soggy stretch in the middle when Max quits the force and settles down in soft focus with his wife and child' ${ }^{42}$ The family buy a dog, run through fields of corn and caper about a waterhole. But the gang follows them, and Max's wife and child, Jessie and Sprog, are run down as they try to escape. With Sprog killed and Jessie in intensive care, Max returns to the role of lawman. Max 
takes revenge on the gang and becomes the callous, vicious killer he stepped back from earlier. This is evident when Max faces the last gang member, Johnny the Boy. He cuffs Johnny's ankle to a wrecked car, sets the vehicle alight and hands him a hacksaw. If Johnny wants to escape before the car explodes, he only has enough time to cut through his leg, not the handcuffs. The film offers no evidence that Johnny survives Max's grim revenge. Mad Max concludes with a shot following the central road markings, presumably from Max's car as he speeds along the highway, suggesting that his journey has begun, not concluded, with the Screw Jockeys' violent end. Max has tentatively started the arc that will see him fulfil his status as hero, although his heroism is decisively antiheroic at this point. He eschewed the role Fifi outlined for him, preferring to retreat into an idyllic family set-up, but the shattering of that unit forced Max to resume his heroic evolution. Newman's Marvel Comics comparison could be extended to Spiderman as a particular precedent for the archetypal trajectory Max traces. Max and Peter Parker, Spiderman's alter ego, both shelter with an elderly female named May, and they cannot refuse the role of hero after criminals destroy their family units. As the second film in the Mad Max trilogy declares in its opening narrative, 'He lost everything. Became a shell of a man $[\ldots]$ haunted by the demons of his past. He wandered out into the wasteland [...] learned to live again.'

In Mad Max II (1981; also known as The Road Warrior), Max is again the reluctant hero, defending a fortified oil-refining community under siege from another gang of lawless barbarians. The community desires to break out of their containment and reach 'paradise' 2,000 miles away, on the coast of Northern Australia. This scenario repeats the European and American colonial tradition of lone frontiersmen rescuing embattled communities from the savage hordes surrounding them. ${ }^{43}$ Mad Max II also reproduces that tradition's visual codes of savagery and civilization. The townspeople are all white, often Aryan in appearance, with the whites and creams they predominantly wear drawing attention to their skin colour. Their adversaries, led by the monstrous Humungus, are shaggy maned, dressed in fur and feathers, and some have Mohican haircuts, the savage's coiffure of choice. Further, the townspeople are productive, entertain freedom of speech, and in their oil refinery, possess the most potent symbol in the film trilogy that they remain civilized. The savages are antisocial, nomadic and their prisoners are subjected to crucifixion and acts of sexual violence.

Max does not automatically aid the beleaguered community, preferring to spy from afar on the siege. When one of the townspeople is attacked outside the compound, Max makes sure he returns him to the safety of 
the fort, but only for fuel: 'I'm just here for the gasoline.' They refuse, but agree that Max can have his vehicle back, and as much fuel as he can carry, if he retrieves a truck that will pull the fort's oil tanker from outside the compound. When Max brings back a lorry cab, the character Warrior Woman shows she no longer considers him an opportunist thief: 'I was wrong about you.' The community assume Max will drive the tanker out of the fort and help them to escape, but as in the first film, Max refuses to be the hero and announces, 'It's been a pleasure doing business with you, but I'm leaving.' He intends to escape the besieged community alone, avoiding unnecessary conflict in the name of self-preservation. As Max makes final preparations to leave, he is once more interpolated as a brave hero, the Gyro Captain telling him 'You're not a coward.' When Max drives out of the fort, the savages force his car off the road, assuming he is killed when it explodes. However, Max is airlifted back to the fort and, hastily rehabilitated, informs the community he will drive the tanker while they escape in a school bus (he has no alternative if he wants to survive). The townspeople successfully make their way to freedom as Max draws the attention of the gang away from them, and the savages are wiped out as they chase the tanker. Max's mission, ensuring the community's safe passage, succeeds. The lorry cab, with the manufacturer's name (MACK) emblazoned on the bonnet, suggests through its phonetic similarity to 'Max' that he was destined to be the hero driving the tanker, protecting the townspeople by facilitating their escape to safety.

Mad Max II confirms that Max may defend civilization but he cannot rejoin it. Fitting the lone frontier hero of the Western genre, Max has spent too long fighting the forces of savagery to be re-absorbed back into the camp of civilization, and he disappears into the wilderness. ${ }^{44}$ Moving easily between the settled white community and the desert wastes outside its walls allows Max to defend the townspeople much more effectively. A young boy, who moves in and out of the fort through tunnels, mirrors Max in that regard, and he treads behind Max within the compound. This Feral Kid does not share the Aryan looks of the townspeople, and instead wears furs and sports long hair. Feral Kid is depicted and treated like an animal, howling with laughter at Max's music box, or when Max kills a gang member. Just before Max drives out of the fort alone, he shoos Feral Kid away like a pet: 'Scat! Ssss!' However, whereas Max cannot rejoin civilization, the Feral Kid is part of the community and the Captain's Girl hugs him at a meeting. After the battle, Feral Kid can be seen sat on the back seats of the school bus on 'the journey north to safety' and the film's voiceover is revealed as his narration: 'I grew to manhood. In the fullness of time I became the leader. The Chief of the Great North Tribe.' This reve- 
lation of the narrator's identity can read in several ways: the erosion of the oil-refining community into the 'Great North Tribe' may signify the degeneration of its social sophistication, that in its choice of leader the townspeople relinquish urban social codes for a crude hierarchy with a 'Chief' at its apex. Alternatively, it may signify the openness of the community, able to accept (as leader) one who is marked in the film as ethnically Other. Perhaps most appropriately, one can account for Feral Kid's chieftainship as a counterpoint to Max's heroic persona at this juncture in the trilogy. It underscores Max's distance in Mad Max II from the role of willing hero, but prefigures the unforced heroism Max performs in Beyond Thunderdome. If Feral Kid can transcend his youthful itinerancy - protecting the community but only provisionally within it - and grow into its leader, then how can the eponymous protagonist of the trilogy permanently resist the similar claims that are made on him?

In Mad Max II, the community Max defends matches the colonial model of embattled, isolated fort. In the third film in the trilogy, civilization shifts into the community of Bartertown, which, while characterized by colonial signifiers, is far more racially and culturally mixed. The jazz music in Aunty's abode echoes Jessie's saxophone playing in Mad Max, highlighting Max's long passage from the domestic milieu that was once his home. This echo of the first film emphasizes that Bartertown, ordered by unmerciful self-interest, represents the only form of social organization into which Max is able to fit. But Max's lingering sense of morality, refusing to kill a defenceless opponent, renders him ineligible for Bartertown citizenship. This virtuousness is part of the development of Max's character from antihero to hero. By the film's end, as he chooses to sacrifice himself for the children, Max 'isn't mad any more'. ${ }^{45}$ Completing his heroic trajectory, Beyond Thunderdome's narrative positions Max's entanglement with Aunty and Bartertown as an obstacle preventing Max from fulfilling his new role as redeemer to the children, returning them to their promised land. For this to happen Max must rescue the most adventurous children, first, from the soft place of the Australian desert, second, from Aunty's revenge after they raid Bartertown for supplies. In this raid, Master is freed and Bartertown toppled, completing the narrative threads left unresolved when Max was punished and sent into the desert. The narrative demands placed on Max as hero, demands established by the character's journey through the first two films, compel him to aid the children on their voyage. Rayner reads the ending somewhat differently, conceding 'Max's heroic tasks grow in stature and destructiveness as the cycle progresses', but arguing that his heroism is muted because he remains behind while the Gyro Captain flies the plane containing the children. The Gyro Captain assumes the role of 
the long-awaited pilot-saviour which Max had failed signally to fulfil' ${ }^{46}$ This reading seems over-literal and can be usefully balanced by taking account of Max's requisite role in enabling the children's journey onwards and the symbolic importance he is invested with in their invented mythology. It seems to me that Max's fulfils his role as a hero, but still within the constraints of the Western genre - he defends civilization without ever joining it and returns, at the film's end, to itinerancy. What compounds his heroism at this point is that he does so voluntarily. Max restores the children to the sense of belonging he was exiled from in Mad Max by the murder of his wife and child: they are Max's symbolic substitutes, returning home because he cannot. The children's quest is articulated by Turner in the theme song - 'all the children say [...] all we want is life beyond the Thunderdome'. Thunderdome, and the community surrounding it, stand in the way of Max living up to his billing as hero - thus Bartertown must be eliminated. Max's masculine heroism is realized through the destruction of Aunty's civilization, removing the stubborn and ambivalent community that is at once an urban postcolonial celebration of difference and a brutal, inverted colonial outpost of trade. Max returns the soft place of the desert to its original, featureless state, permitting future narratives to be written or filmed on its blank canvas (press reports of a fourth Mad Max film periodically resurface ${ }^{47}$ ). Bartertown, and the ambivalence it represents, makes way so that Max can satisfy the role of hero he has been repeatedly addressed as, triumphing in his third cinematic appearance.

Beyond Thunderdome offers a vision of the post-nuclear-war world as terra incognita, comparable to pre-explored, precolonized soft places. This landscape is overdetermined by the Eurocentric perception of the Outback's disorientating sands and Australia's spatial-temporal marginality to modernity. The film bears a complex relation to the colonial tradition, in which the soft place is itself an ambivalent space, terrifying in its unfathomed magnitude, pleasurable as the site of colonial adventures. In Beyond Thunderdome an African-American woman has resumed the project of building civilization on unoccupied land. Max, white and male, leads an uprising of people encoded as indigenous and working class against Aunty Entity, and the success of the uprising creates even greater ambiguity around the film's depiction of the colonial narrative. Audiences cheering the victory of Max, whose race and gender fit the ideological project of European imperialism, are also celebrating the collapse of civilization and colonial urbanization. Further, the Bartertown Max destroys represents an appropriation of imperial machinery by those deemed less human in the master narrative of white supremacism: the notion of civilization has 
shifted away from the predominantly white community in Mad Max II. Audience allegiances are strained between Max and Aunty, the heroic central character at odds with civilization and civilization's ruler. Beyond Thunderdome does not resolve this ambivalence. The film removes it through spectacular destruction, necessitated by Max's evolution as a heroic figure. And even then closure remains tentative. One is left with the sense that after the film ends Aunty will rebuild her community, staging the civilizing mission once more in the shifting sands of the post-nuclearwar soft place.

\section{Notes}

1. Lefebvre, The Production of Space, p. 109.

2. Quoted in Boyer, By the Bomb's Early Light, p. 120.

3. Elizabeth DeLoughrey, 'Radiation Ecologies and the Wars of Light', Modern Fiction Studies, 55.3 (Fall 2009), p. 470.

4. Neil Gaiman and John Watkiss, 'Soft Places' (July 1992), in The Sandman: Fables and Reflections, Titan, London (1994), pp. 140-41.

5. See Carey (ed.), The Faber Book of Utopias, pp. 84-100, 120.

6. Paul Carter, The Road to Botany Bay: An Essay in Spatial History, Faber, London (1987), p. 56.

7. J. M. Powell, 'Conservation and Resource Management in Australia 1788-1860', in J. M. Powell and M. Williams (eds), Australian Space, Australian Time: Geographical Perspectives, Oxford University Press, Oxford (1975), p. 26.

8. Anne McClintock, 'Maidens, Maps, and Mines: The Reinvention of Patriarchy in Colonial South Africa', South Atlantic Quarterly, 87.1 (Winter 1988), p. 151.

9. Shohat and Stam, Unthinking Eurocentrism, p. 147.

10. Powell, 'Conservation and Resource Management in Australia 1788$1860^{\prime}$, p. 63.

11. Gilroy, Against Race, pp. 56-57, 64; Steven Connor, 'The Impossibility of the Present: or, From the Contemporary to the Contemporal', in Roger Luckhurst and Peter Marks (eds), Literature and the Contemporary: Fictions and Theories of the Present, Longman, Harlow (1999), pp. 16-17.

12. Carter, The Road to Botany Bay, p. 161.

13. Quoted in Carter, The Road to Botany Bay, p. 70.

14. Connor, 'The Impossibility of the Present', p. 29.

15. Herman Melville, Moby Dick (1851), Wordsworth Editions, Ware (1992), p. 112.

16. Jonathan Rayner, Contemporary Australian Cinema: An Introduction, Manchester University Press, Manchester (2000), pp. 25-26.

17. Powell, 'Conservation and Resource Management in Australia 17881860 ', pp. 18-19.

18. Carter, The Road to Botany Bay, p. 284.

19. Carter, The Road to Botany Bay, pp. 79, 87, 90-91, 111 1, 146-47. 
20. One observes a version of this association in Mordecai Roshwald's novel Level 7 (1959), narrated by the character X-127 and set in a bunker below the Earth's surface. X-127 is charged with pressing the buttons that launch his nation's nuclear arsenal. His description of World War Three informs the reader the blank spaces of the map are areas that have yet to be bombed, 'like a continent waiting for an explorer to map it'. With some satisfaction, X-127 sees the weapons he has launched colour the empty map to indicate destroyed regions: "The coloured "exploration" progressed into the heart of Zone B almost unchecked [...] The "terra incognita" of the map was rapidly becoming nicely tinted.' Mordecai Roshwald, Level 7, Signet Books, New York (1959), p. 95.

21. Broderick, Nuclear Movies, p. xi.

22. McClintock, 'Maidens, Maps, and Mines', p. 152.

23. Ross Gibson, 'Formative Landscapes', in Scott Murray (ed.), Australian Cinema, Allen \& Unwin and Australian Film Commission, St Leonard's, NSW (1994), pp. 52, 56.

24. Peter Fitting also reads Bartertown as a vision of the urban present, but with the filmic city figuring 'the scandalous images of a disaster that has already happened [...] the collapsing inner cities of the great metropolises of the United States (Watts or the south Bronx)'; 'You're History, Buddy: Postapocalyptic Visions in Recent Science Fiction Film', in George Slusser and Eric S. Rabkin (eds), Fights of Fancy: Armed Conflict in Science Fiction and Fantasy, The University of Georgia Press, Athens, GA (1993), p. 123. However, as my reading here suggests, the colonial tradition of representing Australia is an inescapable parameter on the depiction of the film's Outback city. I think Fitting is absolutely right to stress the transnational influence at work in Beyond Thunderdome, but in relation to his point here, Bartertown seems to offer too many sensory and narrative pleasures to the viewer to be described as a 'disaster'.

25. Paul Gilroy, After Empire: Melancholia or Convivial Culture?, Routledge, London (2004), pp. 108-109.

26. Tom O'Regan, Australian National Cinema, Routledge, London (1996), pp. 95, 323.

27. Shapiro, Atomic Bomb Cinema, pp. 176, 178, 174. See also Fitting, 'You're History, Buddy', p. 116.

28. Carter, The Road to Botany Bay, p. 284.

29. Carter, The Road to Botany Bay, p. 320.

30. Mick Broderick, 'Heroic Apocalypse: Mad Max, Mythology, and the Millennium', in Christopher Sharrett (ed.), Crisis Cinema: The Apocalyptic Idea in Postmodern Narrative Film, Maissoneuve, Washington, DC (1993), p. 272.

31. Brian McFarlane, Australian Cinema 1970-1985, Secker \& Warburg, London (1987), p. 48.

32. Shohat and Stam, Unthinking Eurocentrism, p. 140.

33. Broderick, 'Heroic Apocalypse', p. 265.

34. Fitting, 'You're History, Buddy', p. 126.

35. Angela Carter, Heroes and Villains (1969), Pan and Picador, London (1972), p. 145.

36. Theodore F. Sheckels, Celluloid Heroes Down Under: Australian Film, 19702000, Praeger, Westport, CT (2002), p. 182. 
37. Newman, Apocalypse Movies, p. 184.

38. Gibson, 'Formative Landscapes', p. 56.

39. Quoted in Thomas P. Dunn, 'The Road Warrior: Self and Society in the Rebuilding Process', in Carl B. Yoke (ed.), Phoenix from the Ashes: The Literature of the Remade World, Greenwood Press, Westport, CT (1987), p. 202.

40. Newman, Apocalypse Movies, pp. 185, 191.

41. Rayner, Contemporary Australian Cinema, pp. 37-38.

42. Newman, Apocalypse Movies, p. 184.

43. Wheeler Winston Dixon, Visions of the Apocalypse: Spectacles of Destruction in American Cinema, Wallflower, London (2003), pp. 75-77; Dunn, 'The Road Warrior', p. 202.

44. Fitting, 'You're History, Buddy', p. 120.

45. Newman, Apocalypse Movies, p. 186.

46. Rayner, Contemporary Australian Cinema, pp. 38, 43.

47. Michael Bodey, 'Mad Max Movie Grinds to a Halt', The Australian (7 July 2010), available at http://www.theaustralian.com.au/news/nation/madmax-movie-grinds-to-a-halt/story-e6frg6nf-1225888700431 (last accessed July 2010). 


\title{
4 Fear of a Black Planet
}

\author{
Livin' in a land where the law say \\ Mixing of race makes the blood impure \\ What is pure? Who is pure? \\ Is it European? I ain't sure \\ If the whole world was to come \\ Through peace and love \\ Then what would we [be] made of? \\ $[\ldots]$ \\ Why is this fear of Black from White \\ Influence who you choose? \\ Public Enemy, ‘Fear of a Black Planet'1 \\ Senator Theodore Bilbo ${ }^{2}$
}

[I] would prefer to see my race and my civilization blotted out with the atomic bomb than to see it slowly but surely destroyed in the maelstrom of miscegenation, interbreeding, intermarriage, and mongrelization.

The 'black planet' that the popular rap group Public Enemy refers to is the Earth of the future. This feared Earth is not one where all other races have been replaced by the black African diaspora: this planet is 'black' ('or just brown') because the colour lines determining procreation and biological issue will be ignored by our descendants. If those lines are overridden by love and sexual desire then the racial categories of the twentieth century will be irrevocably intermingled. Public Enemy rapper Chuck D asks defenders of racial purity, 'What's wrong with some color in your family tree?' and reminds listeners that every human being can trace their ancestors back to Africa. 'Fear of a Black Planet' hypothesizes a future where purity is not defined by racial homogeneity, and given the associations of purity with goodness and virtue, Chuck D especially questions the monopoly on purity historically attributed to 'European' whiteness. The addressee of this song is told that if human love is allowed to flourish without the choice of romantic partner being influenced by a need to defend racial purity, the racial composition of humanity will be very different in the future. 
'Fear of a Black Planet' comes from the 1990 album of the same name, on the cover of which the Earth falls under the shadow of a featureless darkened planet which has the Public Enemy band logo burning on its surface. By visualizing the Earth as a jeopardized sphere, and emerging at the end of a decade of heightened fears of nuclear war between the USSR and the USA (an earlier Public Enemy track is entitled 'Countdown to Armageddon'), it is difficult not to read the blackened planet heralded by the album title as an Earth scorched by World War Three. ${ }^{3}$ The title of the album and the song twins fear of nuclear war with fear of a future where the social codes of sexual reproduction have evaporated and the subsequent intermixture makes racial distinctions irrelevant. As this chapter will explore, several American cultural texts do similar work in twinning these future possibilities, often seeing the former as a prerequisite of the latter. The representation of post-nuclear-war worlds often exploits the emotional and political charge of interracial relationships in a future where existing social codes seem tenuous or inapplicable. Without interracial sex particularly in mind, literary scholar Daniel Cordle notes the romantic opportunities offered by the post-nuclear-war world in literature: 'The post-holocaust environment can be treated frivolously, ripe, for instance, with possibilities for sexual adventure uncensored by the taboos of civilisation. ${ }^{4}$

Interracial sexual relations - known as miscegenation - are massively important in the history of Western racism. New World slavery accredited slave status along the line of 'maternal descent', so the children born of black female slaves and white male masters (or any other fathers) were legally slaves. ${ }^{5}$ While difficult to assess, it would seem the rape of female slaves by their masters was endemic across New World plantations, leading Du Bois to state that 'two centuries of systematic legal defilement of Negro women had stamped upon' African America the 'red stain of bastardy' and 'the hereditary weight of a mass of corruption from white adulterers' ${ }^{6}$ In New World slave societies it was common for a person with mixed heritage to be legally black. Mixed race offspring were subject to intricate mathematical calculations and legal stipulations as to their official status, which varied depending on time and place. In the American context, marriage between a white person and a person of 'one-eighth [...] negro blood' would have been illegal in Missouri in 1906 but legal in Oregon (where a 1902 code only made it unlawful for a white person to intermarry with any negro, Chinese, or any person having one-fourth or more negro, Chinese, or Kanaka blood ${ }^{7}$ ).

Anthropologist Claude Lévi-Strauss commented that, along with the incest with which it is sometimes combined, in 'some countries [...] inter- 
racial sexual relations' are the most taboo versions of kinship available, stimulating 'horror and collective vengeance' ${ }^{8}$ The legal prohibitions on interracial sex in Europe's colonies have a long history, beginning with the Spanish Empire in the sixteenth century. At the start of the 1980s, interracial marriages were still illegal in South Africa and the US state of Mississippi. ${ }^{9}$ The offspring of interracial relationships in New World slave societies were condemned scientifically, too. Biologists posited human extinction as the long-term repercussion of interracial sex. This rested on the belief that people identified as mulatto (a term used in reference to people of mixed race) would be barren if they bred with other mulattoes. ${ }^{10}$ Scientists also proposed mixed race offspring were weaker and more effeminate and susceptible to disease, and the intermixture of white and black racial stock represented the dilution of white vigour and the eventual decline of civilization' ${ }^{11}$ (a counter-theory of 'Hybrid vigor' proposed that racial intermixture would bring vitality and cultural stimulation ${ }^{12}$ ).

White men were the least penalized group in interracial sexual relations - unless they married a woman on the other side of the colour line. ${ }^{13}$ Black men, conversely, were the most demonized, and their sexual transgression of the colour line - actual or otherwise - the most punished. Frantz Fanon puts it bluntly: 'We know historically that the Negro guilty of lying with a white woman is castrated.'14 James Baldwin saw the American South as a particularly dangerous environment in this context: 'How many times has the southern day come up to find [a] black man, sexless, hanging from a tree!' ${ }^{15}$ Baldwin's typical victim is 'sexless' because lynching victims were often castrated, an act symbolizing the supposed reasoning behind the lynching, that black men were sexual predators preying on white Southern women who had to be protected via extralegal means. ${ }^{16}$ The perception of 'the Negro' as representing 'sexual instinct (in its raw state) [...] genital potency beyond all moralities and prohibitions ${ }^{\prime 17}$ is widespread in white supremacist ideology, and as scholar Richard Godden has summarized, the image of the 'black beast rapist' had a privileged symbolic function in the racial economy of the American South, particularly from the mid-1880s onwards, when defenders of the dismantled slave system saw 'a generation of young blacks [...] coming to manhood without the "civilizing" effects of slavery' ${ }^{18}$ Without slavery in place to control the insatiable black male, white Southern womanhood was perceived to be endangered by black lust. This jeopardy seemed all the more immense because of the cultural capital invested in the chasteness of the white woman in the South, celebrated as 'gleaming white' and 'lily-pure [...] Mother of God'. ${ }^{19}$ To compensate for the challenge to racist hierarchies opened up by Emancipation, 'the weaponry of Jim Crowism (disenfran- 
chisement, segregation, lynching) supplied the only means to subordinate blacks as they degenerated' in the eyes of Southern Radicals. ${ }^{20}$ The uncontrollable lust of former slaves was the alibi for the violent suppression of black people in the South, murderous acts that also had the aim of maintaining the Southern system of racial subordination. As many as 416 African Americans were lynched between 1918 and 1927. ${ }^{21}$

Frederic Brown and Mack Reynolds's SF story 'Dark Interlude' (1951) depicted this immoral violence and its official tolerance. A traveller from Earth's future visits rural America and marries a local white girl. Initially, the time traveller is accepted by the locals until he reveals his racial origins to his wife's brother, who automatically murders the time traveller. As he tells the story of the murder to the Sherriff, the brother recounts that the time traveller was talking about a war in the future in which 'the whites and the yellows had mostly killed one another off'. After this war, 'all the races had begun to blend into one by colonization and intermarriage' and by the time the time traveller was born this 'process was complete'. Enraged that this man 'was sleeping with' his sister, the brother demanded, 'You mean you got nigger blood in you?' On hearing the time traveller's innocent answer ('he said, just like it didn't mean anything, "At least one-fourth."') the brother shoots him dead, an action of which the Sheriff approves. ${ }^{22}$ Despite the story's intended illustration of the hostility faced by mixed marriages, it is important that the future the time traveller comes from is characterized by racial mixing. 'Dark Interlude' indicates that the brother's murderous intolerance is fighting against the historical tide; the unremarkableness of racial intermixture - 'it didn't mean anything' to the time traveller - is the inevitable outcome of racial difference's lessening grip on the comprehension of human relations. As Paul Gilroy has observed of the first interracial kiss screened on US television, between Captain Kirk (William Shatner) and Lieutenant Uhura (Nichelle Nichols) in Star Trek, such texts offer the idea that to be against racism is to be allied to the future. ${ }^{23}$ People who reject racism are already bound to the world of tomorrow and are building that future, while racists remain trapped in the logic of the past. In Star Trek and 'Dark Interlude', the depiction of a future free of racism implicitly underlines that its existence in the present cannot endure indefinitely.

Interracial sex has been discussed in relation to the maintenance of racist hierarchies long into the twentieth century. While (mercifully) not representative of the majority of nuclear representations, in Andrew Macdonald's novel The Turner Diaries (1978), a neo-Nazi group called the Organization seize California and an arsenal of nuclear weapons in 1993. The book's narrator, a member of the Organization, repeatedly proclaims 
his commitment to preserving 'the future of our race' 24 against the threat of black male sexual predation. The Organization launches nuclear missiles at the USSR, triggering an exchange between the Soviet Union and the USA that severely weakens both states and allows the group to take power in North America (and Europe in 1999). Victory becomes tangible when the narrator destroys the Pentagon with a nuclear warhead. The novel, a first-person narrative, is framed as a historical document published one hundred years after the events it narrates. The frame narration reveals that after another nuclear war Asia has been depopulated and only white people now inhabit the Earth: the Organization's race war has been successful. This novel is an extreme variant of future-war fiction that reaches for nuclear weapons as the means to prevent racial intermixture. Its appeal to racism and genocide is so blunt it is important as a political document but of limited literary interest.

Few scholars have demonstrated the centrality of interracial and interethnic sexual and romantic relations within American culture as extensively as the scholar Werner Sollors. In Beyond Ethnicity, Sollors outlines how heterosexual romance has been at the heart of American narratives of ethnic allegiance. The core of his theory is the tension between vertical lines of descent (conduits of ethnic belonging expressed through the rhetoric of natural bloodlines) and horizontal lines of consent (chosen affiliations in which participants bind themselves to the national community, perhaps by agreeing to adhere to American law). This tension is at work within an individual American's identity and is often manifested in the heterosexual relationships into which they enter: choice of partner is a statement on how the individual is positioned and positions themselves between the demands of descent and consent relations. ${ }^{25}$ In one sense, that tension between descent and consent is the balancing act between an American's ethnic or racial identity and their American national identity. For some commentators, taking up US citizenship means sloughing off one's prior identity, be that ethnic, racial or a preceding nationality. In this modulation, being nothing but an American means renouncing all other ties inherited from the past and being remade in the American mould. The most famous formulation of this overriding American identity was contained in Israel Zangwill's play The Melting-Pot (1909), addressed to the surge of migration from Southern and Eastern Europe entering the USA's eastern cities from the 1880s to the 1920s. For Zangwill, it is God's will that all immigrants have their particularity burnt off and replaced with a uniform American national identity:

America is God's Crucible, the great Melting-Pot where all the 
races of Europe are melting and re-forming! Here you stand, good folk, think I, when I see them at Ellis Island, here you stand [...] in your fifty groups, with your fifty languages and histories, and your fifty blood hatreds and rivalries. But you won't be long like that, brothers, for these are the fires of God you've come to [...] A fig for your feuds and vendettas! Germans and Frenchmen, Irishmen and Englishmen, Jews and Russians-into the Crucible with you all! God is making the American. ${ }^{26}$

Underlining the metaphor was the belief that contact, intermixture and interethnic reproduction would erase the descent identities of American immigrants, leaving citizens that were simply American. This model has deep historical roots and certainly goes back to the eighteenth century. ${ }^{27}$ While Zangwill's list of peoples in the above quotation suggests his melting pot is homogeneously white, he envisaged all races adding to the mix, appending an afterword to the play in 1914 to make this point clearer. ${ }^{28}$ Importantly for this chapter, Sollors observes that 'marital union or a love relationship across boundaries that are considered significant, and often in defiance of parental desires and old descent antagonisms, is what constitutes melting-pot love'.$^{29}$ As precursors to procreation, these romantic and marital relations will generate an American identity where descent claims are irrelevant.

The promise of heterosexual relations across the lines of racial and ethnic allegiance, the promise to deliver the American melting pot, finds a unique situation in those post-nuclear-war representations set in a massively depopulated America. In such texts, the realization of the American melting pot in biological terms is not the eventual outcome of cultural intermingling. The issue of which people survive and which of those survivors reproduce takes on an added dimension because those offspring directly represent America's future. The racial recipe of the survivors and their descendants determines who is to repopulate the United States. Where these characters are the last humans alive they represent the progenitors of humanity's future. Interracial sex repeatedly vexes the racist imagination and in post-apocalyptic representations it takes on greater importance - and is the source of consternation and violence - because it may compromise white racial purity for posterity. Conversely, where white Americans are the sole survivors (more importantly, the sole survivors to reproduce), non-white Americans are written out of the country's future.

This chapter marks out different versions of the racial recipe of nuclearwar survivors offered by American cultural texts. The first section examines novels from the 1950s in which the destruction of America's urban centres and the relative safety of suburban and rural areas ensures the longevity 
and social status of white Anglo-America. In addition to the spatial politics of survival, the white protagonists' choice of romantic partner (i.e. reproductive mate) determines whether this ethnic group is to remain dominant in post-nuclear-war America.

The second section looks at films and novels from the 1950s and 1960s in which a very small group of Americans survive a nuclear war. The selfselection of sexual partners within these racially plural groups initially appears beholden to social taboos on interracial sex in the USA during the period of their production. The very different endings to the narratives, however, indicate that the writers and filmmakers were 'trying on for size' the kinds of familial unit made possible by disposing of said taboos. Mildly desegregationist, these texts use the post-nuclear-war setting and the evaporation of racist institutional structures to expose racism in its most absurd, naked and hostile form.

The third section focuses on the SF fiction of African-American novelist Octavia E. Butler, which uses the topic of interspecies reproduction to stage a complex negotiation of the demands of kinship when faced with repulsion against physical difference. Furthermore, Butler's drama of who is to represent humanity's post-nuclear-war future is addressed to the nuclear belligerency of President Reagan in the 1980s, arguing for an accommodation of difference as a counter to the aggressive rhetoric of the Reagan administration.

\section{Inner-City Annihilation}

During the Cold War, a series of social and economic changes affected America's demographic distribution, such as the rise of middle-class suburbs (which black Americans were often prevented from moving into by restricted housing covenants) and the release of thousands of drug addicts and the certified insane onto urban streets following the 1963 Community Mental Health Centers Act. ${ }^{30}$ Inner cities came to be perceived as the site of pathological family scenarios, interracial tension and criminality - not least in the minds of American policymakers - which reflected and exacerbated the phenomenon of 'white flight'. ${ }^{31}$ America's urban centres were also believed to be the targets of Soviet nuclear weapons. In 1951 the Bulletin of Atomic Scientists proposed dispersing large urban populations into the surrounding environs to minimize loss of life, and when the Interstate Highway Act became law in 1956, President Dwight Eisenhower cited the need to evacuate cities quickly. ${ }^{32}$ Sharp and Preston argue separately that civil defence planning privileged the suburban family (silently encoded as white) on both sides of the Atlantic, ${ }^{33}$ and Dean 
MacCannell contends that strategic planning from 1960 onwards was willing to sacrifice America's cities so the country as a whole would survive. ${ }^{34}$ Fictional representations echo this association. In Archibald MacLeish's poetic drama J.B. (1958), the 'lower-class, ethnically accented voices' of characters fleeing an atomic-bombed city suggest the primary victims in a nuclear strike will be America's multiethnic urban working class. ${ }^{35}$ The protagonist of Bernard Wolfe's novel Limbo (1952) contemplates how nuclear war has 'cleared the slums from America overnight', demonstrating the kind of 'social-engineering efficiency' that 'reformers and uplifters had never been able to' muster. ${ }^{36}$ As Seed notes, the rationalization of atomic bombing as 'a form of urban planning' goes back to 'the first atomic war novel', H. G. Wells's The World Set Free. ${ }^{37}$

Philip Wylie wrote the novel Tomorrow! (1954) to convince the public of the necessity of Civil Defense, and it spent several weeks on the New York Times bestseller list, going through three hardcover printings and selling over 30,000 copies. ${ }^{38}$ Set in the fictional adjacent cities of Green Prairie and River City, when a Soviet nuclear weapon strikes urban congestion compounds the destruction. A map is inserted into the novel at the moment of the blast, and immediately above the cross marking 'Ground Zero' is the 'Negro District', and close by, in even bigger letters, is the label 'Slum'. ${ }^{39}$ In Tomorrow!, and in America's civil defence planning, the destruction of inner cities was expected to enable white suburban Americans to live through a nuclear war. This assumption structures the novel's narrative, which favours the survival of one of those white suburban middle-class families, the Conners: parents Henry and Beth, their children Chuck, Ted and Nora, and Chuck's eventual wife Lenore Bailey, childhood sweetheart and next door neighbour. As Sharp has noted, the novel's annihilation of the inner city should be read as part of Wylie's liberal critique of America. Wylie elaborates how social forces such as racism and poverty have pushed African Americans into decaying urban centres, and he underscores the injustice of this situation by making the black community the most vulnerable in a nuclear attack. ${ }^{40}$ Nonetheless, in Tomorrow! the obliteration of the slums furnishes the 'opportunity' to rebuild River City and Green Prairie as 'Semidecentralized' cities. After the attack they are rebuilt with elongated buildings that leave 'room for gardens, for parks, for picnic grounds right in the center of the city'. The 'bombing had proved an ultimate blessing by furnishing a brand-new chance to build a world brand-new - and infinitely better' ${ }^{41}$ Sharp and Foertsch separately come to the same conclusion: Wylie's condemnation of African-American suffering is exceeded by his utopian desire to remodel America's cities in the shape of the suburbs, and the African-American community stands in 
the way of his projected urban redemption. While some members of River City's black community do survive the nuclear strike, it is implied this community has suffered the greatest share of the attack.

Tomorrow! opens with the area's fictitious history of settlement, the establishment of trade, agriculture and industry by white pioneers fighting off Sioux attacks, and at the novel's conclusion white 'settlers' build over areas previously inhabited by African Americans. Sharp further connects the nineteenth-century settlers to the nuclear-war survivors as follows: the frontiersmen able to survive and reproduce demonstrated the qualities of rugged individualism, determination and heroism. These qualities have been passed down to their descendents, the Conners, and they prove crucial for the Conners' survival in a nuclear attack. ${ }^{42}$

Having survived the nuclear war, the last chapter suggests the Conner family will inhabit Green Prairie in the future: Chuck and Lenore, now married, are expecting their first child, making the continuing reproduction of white America the dénouement of the novel..$^{43}$ The happiness that greets this news is unsurprising because of the threat to fertility posed by radiation. In the context of repopulating America, Chuck and Lenore's unborn child is a patriotic act: 'does this country need babies now!' ${ }^{44}$ During the narrative, Lenore must choose either Chuck or Kit Sloan to be her husband, and alongside the nuclear war scenario, the narrative makes this the major question to keep readers interested. Her eventual decision deserves close scrutiny because it evidences the subtle racial politics of mate selection. Kit Sloan is the outcome of his mother Minerva's bad parenting: he is 'mother-dominated', infantile, cowardly and insecure, ${ }^{45}$ and epitomizes Wylie's view that 'overbearing mothers' were turning American children into 'effeminate, self-involved degenerates' ${ }^{46}$ Lenore is blackmailed by the Sloans into an engagement with Kit, who tells her the 'family line must be continued. I must find somebody steady, intelligent, healthy, good family, sound stock - you'd really fit the whole catalogue.' While Kit thinks Lenore would be unhappy 'being a mere brood mare', Minerva is confident she 'can be handled' ${ }^{47}$ their lexicon constructing her as livestock selected to maintain a pedigree. In Tomorrow!, atomic bombs have the advantageous effect of 'keeping the all-American girl safe from' Kit Sloan since the scion is murdered fleeing the nuclear strike. ${ }^{48}$

Lenore's choice is between a romantic match with Chuck and a loveless financial match with Kit, so finishing the novel with her romantic choice manoeuvres the reader into supporting her consent union with Chuck. But despite its message that the bonds of love are the most important, the pairing of Lenore and Chuck insinuates that their romantic match is complemented by their compatibility as wholly white. A further reason 
for Kit's unsuitability is his genetic inheritance, the genealogical secret lying behind the 'Sloan darkness'. This darkness is a colouring of the skin symbolizing the Sloans' moral 'darkness', a genetic inheritance from 'a carefully forgotten' forebear, indicating the shame attached to the original source, 'an Indian squaw [who] had participated in combining the Sloan genes' ${ }^{49}$ William Javier Nelson used the term 'hypodescent society' to define the way status is assigned to mixed ethnic identities in America. Ancestry from a subordinate group carries disproportionately large weight, and as such, no matter how long ago 'the Sloan genes' were 'combin[ed]' with Native America, this evidence from the text belongs in an American tradition where 'any "impure" ancestry' overrides the privileged components in biological selfhood..$^{50}$ The Conners' ancestors defended the early frontier settlement of Green Prairie against Native American sorties; the Sloans' ancestors trafficked with people lined up against civilization. The consent match between Chuck and Lenore is also a descent match, keeping Kit's problematic genetic inheritance away from the fertile white woman's biological stock and away from the future citizens of America.

There is an exposition of 1950s US society in Tomorrow! that complicates the reading of white America's regeneration of the city as a victory for civilization. Wylie seems too cynical about human nature to see white American culture as an improvement on barbarism and Tomorrow! insists upon the almost universally rejected fact that people are, after all, animals'. Although Native America functions as the high water mark of savagery, the novel implies that US mass culture is a veiled version of human barbarism that erupts after the nuclear strike. The 'presence of the end of the world' gives licence to behaviour that 'had thitherto been only fantasy', behaviour that is 'criminal' and 'psychopathic' and frequently involving rape. This is not the case in the Conners' community, but that is because of preparedness, not racial superiority. Even the Conner family enjoy American television comedy, the subject of Tomorrow!'s most caustic comments. The laughter it elicits is homogeneous - a 'collective guffaw' and mechanical, since the audiences 'laughed without knowing why, or even that they laughed'. Audiences are depersonalized and unthinking and the 'utterly savage sound' they make is 'inspired by the sadisms which constitute most popular humor. It is a sound that would stun to silence the predatory night noises of the wildest jungle, a sound of madness'.$^{51}$ The jungle is an extensively wrought symbol of civilization's antithesis ${ }^{52}$ and the sadism, barbarism and mass behaviour that Tomorrow!'s narrator identified in television comedy are the leitmotifs of post-nuclear-war atavism. The mobs are referred to as a mass sapped of sanity, using the terms 'maniacal hordes', 'dark smear of humanity' and 'human amoeba'. ${ }^{53}$ 
African-American characters stand outside Wylie's critique of American mass culture and offer a moral alternative, teaching white America how to maintain community and decency as atavism takes hold of white River City survivors. ${ }^{54}$ The roles they play after the nuclear strike are 'healers and saviors', most notably the character Dr Alice Groves, the selfless manager of the Mildred Tatum Infirmary for Colored. The postwar rebuilding depends upon Alice's exertions since it is Alice who saves Minerva Sloan's life, and Minerva funds the new bank building in the rebuilt twin cities. Appropriately for a novel caught between liberal critique of racism and the desire to wipe out inner-city African-American communities to reconstruct the urban environment, black characters demonstrate superior resources of courage and nobility after the nuclear strike, but (with the exception of Alice) are discussed in general terms and act for the benefit of the white characters and the new city they build. ${ }^{55}$

Like Tomorrow!, Pat Frank's 1959 novel Alas Babylon suggests that after a nuclear strike the people who rebuild the nation will come from outside its urban centres. Alas Babylon went through 43 printings by 1983 and was adapted for a prestigious television 'playhouse' series. ${ }^{56}$ It is also explicitly critical of American racism, but the nature of this community's survival reasserts racial hierarchy, as does the novel's presentation of the male protagonist's choice of partner.

In Alas Babylon, rebuilding takes place in the Florida town of Fort Repose, cut off from the rest of the country on 'The Day' (the community's term for the day of the nuclear attack). The novel's title, a codeword for nuclear war between two of the characters, comes from Revelation. It refers to God's destruction of the sinful city of Babylon, knitting together the idea of America's urban centres as places of crime and immorality and as targets in World War Three. ${ }^{57}$ Alas Babylon indicates that in a nuclear war 'big cities would become traps deadly as deserts or jungles' and the exodus of refugees, as 'voracious and all-consuming as army ants', would denude the resources of little towns. ${ }^{58}$ In this, Alas Babylon and Tomorrow! may be influenced by the earlier short stories 'Lot' (1953) and its sequel 'Lot's Daughter' (1954), written by Ward Moore. Their titles also suggest God's destruction of cities for their sins, in this case Sodom and Gomorrah. Following a nuclear attack, Moore's protagonist Mr Jimmon is so desperate to outrun 'the endless mob pouring out of Los Angeles [...] eating up the substance of the surrounding country'59 that he sacrifices three members of his family: Jimmon sends his wife and two sons into a filling station and drives off with his teenage daughter. The short stories' titles allude to Lot from the Bible to establish the selfishness and self-righteousness of both patriarchs in their bids to survive (see Gen. 19:8). 
Against the city as epicentre of America's devastation, Fort Repose is a site of survival whose origin as a frontier outpost is stressed. ${ }^{60}$ Similar to the Conner family, in Alas Babylon the Braggs (represented by Randy, his brother's wife and her children) are the descendents of the earliest white settlers. The Braggs band together with other families living by the river, including the Henrys, the descendants of the slaves that Randy's forefather brought with him to Fort Repose. After The Day, this miniature river community embodies the self-reliance classically associated with the frontier. ${ }^{61}$ Randy Bragg accepts the responsibility of protecting the community when the Acting President empowers Reservists and National Guardsmen to 'take independent action to preserve public safety'. When the town is threatened by murderous highwaymen (one of whom resembles 'a Western badman holding up the Wells Fargo stage'), Randy leads his men in a shootout against the gang. The last highwayman is hung as a warning to others. Randy literally writes Fort Repose's new laws into being and accredits himself with the authority of seeing them executed. ${ }^{62}$

Alas Babylon ridicules the absurdity and arbitrariness of America's racial codes, making segregationists appear un-American by having such characters oppose free speech. The novel also states that black and white soldiers can socialize freely when serving overseas. ${ }^{63}$ The novel's liberal position is repeatedly dramatized after The Day, when desegregation seems inevitable because of circumstance. ${ }^{64}$ For instance, segregated civic resources are meaningless when resources stop working, such as the "two drinking fountains [...] marked "White Only," the other "Colored Only"'. Gradual desegregationist Randy is a 'little surprised' when Caleb Henry attends classes with his niece Peyton and nephew Ben Franklin, but why should this be remarkable? Randy recalls in their hometown of 'Omaha - and indeed in two thirds of America's cities - white and Negro children had sat side by side for many years without fuss or trouble'. Outlining the full role African Americans take as trading partners, the novel's narrator is blunt. There can be 'no color line' when life is ruled by 'laws of hunger and survival'. In Alas Babylon, it is evidently ludicrous that a nuclear war is required to desegregate the South. The mutual dependency of black and white Americans is a feature of the river community: the Braggs' small arsenal of firearms protects the river community, and the local knowledge of Preacher Henry allows Peyton to catch fish in a time of hardship. ${ }^{65}$ For Bartter the Henrys have a privileged place in the narrative because they 'understand the farming techniques and resources of the area' and therefore 'truly hold the key to the group's survival' ${ }^{66}$

Cordle observes 'even in [the novel's] most liberal aspect', its full appreciation of the black characters' contribution to the community, Alas Babylon 
'reveals conservative assumptions about racial difference' ${ }^{67}$ The Henrys are depicted in terms that suggest their primitivism, as if blackness is an ontological condition that has yet to enter history. ${ }^{68}$ When the two teenage boys report for guard duty, Caleb Henry 'stepped out of the shadows, teeth and eyes gleaming. Incredibly, he carried a six-foot spear.' Even after the nuclear war, the Henrys' home ('what had once been the slave quarters') is a tableau of slow agricultural labour, fishing and contented daily routine. 'It seemed a peaceful home, in time of peace. ${ }^{69}$ The condition of African America is presented as a static and primitive bedrock, undisrupted by nuclear war, and the Henrys repeatedly adopt positions of happy servitude in relation to the white characters. ${ }^{70}$ For Randy, the Henrys are a 'special problem. [...] They owned their own land and ran their own lives, but in a sense they were his wards. ${ }^{71}$ As James Baldwin commented in 1960, considering the 'Negro' as a 'ward' was 'indispensable' to 'national self-esteem'. It reinforced the infantilization of African America and demonstrated to Baldwin that white Americans were unable 'to look on the Negro simply as a man'. ${ }^{72}$ Sharp and Foertsch argue that the community's very dependence on the Henrys is loaded with value judgments about the level of their civilization. Reduced to a subsistence existence, the people most adapted for survival are the Henrys precisely because they have not reached the same level of technological development as the Angloand Hispanic-American characters, for whom reverting to the postnuclear-war environment is much more difficult. ${ }^{73}$

Sharp interprets Randy's 'struggle to survive on the nuclear frontier' as rejuvenation:

Frank went out of his way to underscore his belief that Darwinian struggle on the frontier reinvigorated men like Randy. [...] He became physically fit, settled down with a nice girl, and took his place as leader of the town like his forefathers. ${ }^{74}$

Randy does stop drinking whisky and loses weight, becoming 'leaner and harder, and, truthfully, felt better than before The Day'. But the novel nuances the Darwinian struggle, and Randy draws back from the credo, 'Today a man saved himself and his family and to hell with everyone else. ${ }^{75}$ Equally, Sharp's contention that the novel has a 'romanticized happy ending $^{76}$ is too strong. When US armed forces finally arrive, the river community chooses to remain in Fort Repose. Colonel Paul Hart readies to fly away and Randy asks him who won the war:

'We won it. We really clobbered 'em!' Hart's eyes lowered and his arms drooped. He said, 'Not that it matters.' 
The engine started and Randy turned away to face the thousandyear night. ${ }^{77}$

Randy and the community have been toughened up and brought together, but the idea of American civilization being regenerated is undermined by that 'thousand-year night'. ${ }^{78}$

A necessary element in Randy's regeneration is his selection of the white American Elizabeth (Lib) McGovern as romantic partner and his rejection of Hispanic-American Rita Hernandez. Before the war, Randy dated 'lots of girls, and not all of them virgins'. His neighbour Florence 'had seen him take Rita Hernandez, that little Minorcan tart from Pistolville, into his house and, no doubt, up to his bedroom [...] And there had been others, recently a tall blonde who drove her own car'. Rita is contrasted (by height, for example) against the blonde Lib, and the reader is informed Randy has had sex with Rita but not Lib before The Day. Rita thinks the 'war's going to level people as well as cities' and consequently Randy will return to her: 'that other girl - that Yankee blonde - won't look so good' ${ }^{79}$ When Rita enters the narrative, her hypnotic combination of sex and danger is clear:

She was not like a girl of Fort Repose. She was a child of the Mediterranean and Caribbean, seeming alien; and yet certainly American. Her ancestors included a Spanish soldier whose caravel beached in Matanzas Inlet before the Pilgrims found their rock, and Carib Indian women, and the Minorcans who spread inland from New Smyrna in the eighteenth century. She had not gone to college but she was intelligent and quick. She had an annulled high school marriage and an abortion behind her. She no longer made such foolish errors. Her hobby was men. ${ }^{80}$

This quotation is less than half the space devoted to describing Rita as she stands in the doorway in shorts and a halter top, brandishing a shotgun. Despite the danger she symbolizes, reading Rita's 'used and tired's1 skin does not give one the confidence that she will live much longer. She is intelligent and tenacious but not cultivated or judicious. Rita and her brother Pete trade food for useless consumer goods, and some of this jewellery gives them radiation poisoning, indicating that their acquisitiveness is a disadvantageous trait in the struggle to survive. Dr Dan Gunn's pessimism about human fertility turns women who can and want to have children into valuable commodities; in terms of which woman will best serve Randy in perpetuating his family and community, Lib is mentally preparing to have children with him while Rita's abortion associates her with failed reproduction. ${ }^{82}$ This association is compounded by Dan's description of Rita's jewellery: 'Impregnated with fallout'. ${ }^{83}$ Foertsch reads 
Rita's irradiated gold ring as her 'symbolic marriage with the bomb', the only union available to her after failing to seduce her social superior, Randy, and 'supposedly just reward' for Rita not knowing her place. ${ }^{84}$

Rita's character is somewhat redeemed later in the novel when she assists Randy in catching the highwaymen, but her biographic description occupies a larger proportion of the narrative and programmes the reader to think that Randy would be wisest choosing the 'Yankee blonde'. Earlier, Randy complained about Rita's possessiveness, and although he thinks Lib is also 'jealous', that is 'natural'. Rita's jealousy appears overbearing, and she interrogates Randy as to which of the female guests in his house he is 'sleeping with'. When Lib agrees to marry Randy, the polarity of possession is returned to its appropriate gender direction:

His eyes measured her - long, slender, curved as if for flight, skin coppery, hair silvered by the night. 'You're a beautiful possession,' he said. 'I wish we had a place of our own so I could keep you. I wish we had just one room to ourselves. I wish we were married.'

Instantly she said, 'I accept.' 85

Schwartz argues that through Lib the novel 'endorses greater personal independence' for women, given her intelligence and outspokenness. Yet the novel 'retains the belief that a strong, decisive man should head the household'. ${ }^{86}$ The transformation that the post-nuclear-war world demands of Randy not only restores his youth, strength and authority, it replenishes his moral behaviour and his masculinity. These are qualities the individual, the community and the nation have been lacking: as Schwartz highlights, the diplomatic incident that leads to nuclear war is the result of a 'sexually insecure American pilot' acting rashly out of a need for social stature.$^{87}$ Before the nuclear attack, Lib complains Randy is 'vegetating' and for their relationship to develop into marriage he must take an assertive gendered role: 'I don't want a vegetable. I want a man.' Conversely, Rita represents the luxuries, seductions and indolence that contributed to Randy's vegetative state: dancing, dining, drinking whisky and having sex in a motel and in the sand dunes, locations adding illicitness to their fornication. After nuclear war, Randy is a profitably altered man, and Rita senses he is 'tougher' and 'not the same Randy'. Before The Day, Randy's opposition to segregation led him to be called 'a traitor to his state and his race', ${ }^{88}$ but his decision to partner with Lib suggests otherwise. His choice of the white woman restores his vigour and he readopts his masculine authority, which protects the community for the benefit of all Fort Repose's ethnic groups. In sticking to his racial compartment, he preserves the human race in the town. This allows the liberal desegrega- 
tionist message of the novel to coexist with the highly value-coded representation of African Americans and Hispanic Americans in Alas Babylon. Randy's authoritarian leadership is made possible by the union of AngloAmerican settler-descendant with his white bride.

\section{The Old Ideologies}

A telling fantasy sequence takes place in Chris Ware's graphic novel Jimmy Corrigan: The Smartest Kid on Earth (2000). The eponymous protagonist indulges in a melodramatic fantasy featuring his black stepsister Amy in which nuclear war leaves them 'the only people left on Earth'. The stepsiblings live in a log cabin and have a child together. Jimmy's belief that the two could start a family is a challenge to the racist taboo on interracial sex, but the fact this takes place after civilization disappears ('everything is $\mathrm{g}$ gone') indicates how far Jimmy thinks this is viable in their present. ${ }^{89}$

This tension between the moral imperative of repopulating the Earth and the social proscription on interracial sex underpins W. E. B. Du Bois's short story 'The Comet' (1920). In Du Bois's narrative, a comet passing New York eradicates the population, except for two survivors, Jim and Julia. Jim is 'a tall, dark working man' and Julia is a 'rarely beautiful and richly gowned' white woman in her mid-twenties. After a period of angst at their situation and their supposed racial difference, a bond forms between them, and the woman says, 'how foolish our human distinction seem - now'. Stripped of any social codes or expectations they are neither 'white nor black': what would such collective identities mean when no other member of those groups remain alive? Jim and Julia are instead the parents 'of the race to be'. Their love is disrupted when it becomes apparent they are not the last people on Earth, or even New York City; both their families are alive, and discover them. The end of 'The Comet' reminds the reader their union would have been punished if it had been consummated. Julia publicly announces that Jim rescued her, but simply being alone together causes the gathering crowd to mutter their desire to lynch Jim. ${ }^{90}$

For much of the film The World, The Flesh and the Devil (1959), directed by Ranald MacDougall, the possibility of an interracial relationship is neutralized by the characters' conscious adherence to pre-nuclear-war racial codes. With echoes of Du Bois's Jim, who was protected from the comet's destruction by the depths of a bank vault, the African-American protagonist of World survives nuclear war because he is a miner underground. Ralph Burton (Harry Belafonte) makes his way to Manhattan and moves into an apartment, believing himself to be the last human alive. Eventually he becomes aware of a young white female survivor, Sarah 
Crandall (Inger Stevens). Film scholar Adilifu Nama reads the presence of a baby carriage in one shot as a symbol of the sexual desire between Ralph and Sarah; ${ }^{91}$ additionally, it implies their union will be necessary for the reproduction of the species. However, though they appear to be the last two people on Earth and there is attraction between them, the black male does not openly desire the white female. When Sarah suggests she move into Ralph's building, he refuses: 'People might talk.' She believes that interpersonal relations have irrevocably changed and 'can't go back the way they used to be', as a slightly later exchange indicates:

SARAH: It's taking you too long to accept things Ralph. This is the world we live in. We're alone in it. We have to go on from there.

[...]

RALPH: Don't push me. I'll be so honest it'll burn you.

SARAH: I know what you are, if that's what you're trying to remind me.

RALPH: That's it all right. If you're squeamish about words, I'm coloured. If you face facts, I'm a Negro. If you're a polite Southerner, I'm a Nigra. I'm a nigger if you're not. [...] Little while ago you said you were free, white, and 21 . That didn't mean anything to you, just an expression you've heard for a thousand times. Well, to me it was an arrow in my guts.

SARAH: Ralph, what do I say, help me! I know you, you're a fine decent man, what else is there to know?

RALPH: That world we came from, you wouldn't know that. You wouldn't even know me. Why should the world fall down to prove I am what I am, and that there is nothing wrong with what I am? [Pause] We leave it the way it is, and I won't mention it again.

SARAH: We haven't said anything about love, have we?

Ralph's involuntary visceral response to Sarah's phrasing indicates how deeply those pre-apocalyptic codes are embedded in him, while Sarah has not had to reflect on her words before, since she belongs to the race that was legally privileged in 1950s America. Ralph cannot fulfil their relationship romantically precisely because he feels it is only possible now the old social codes have been wiped clean. Sarah does not accept that their love is impossible, whereas for Ralph it cannot happen on the grounds of principle, because of white America's failure to acknowledge that he was valid as an object of love before nuclear war made it expedient. However, while Ralph's refusal of Sarah's advances carries moral weight, Sarah's invocation of love seems to undercut his position. As morally rigorous as 
it initially appears, when Ralph's indignation blocks his happiness it appears as stubbornness, as it does when he walks out of the apartment after Sarah's profession of love. Film critic Wyn Wachhorst diagnoses Ralph as having 'racial paranoia', ${ }^{92}$ but the subordination he identifies is made in a convincing and articulate manner - his anger appears to be justified. What is confused in the film is that Ralph presents his position as racial self-respect but he seems to want their relationship to be that of mistress and servant. Ralph stages a night at a club for Sarah's birthday, pours her a drink and addresses her as 'Miss Crandall'.

When a third survivor arrives in New York, the white male Benson Thatcher, Ralph assumes the newcomer will successfully court Sarah. Ben assumes as much and tells Sarah so. She remains in love with Ralph, however, and Ben decides - in his own words - to make her mind up for her. Ben insists on a deadly contest between the two males with the winner claiming Sarah as their prize. Ben gives Ralph a pistol, while keeping a rifle for himself and a duel unfolds down the canyons of Manhattan's deserted streets. As Nama observes, the racial 'stakes are high - the repopulation of the planet'. ${ }^{93}$ After several scenes whose tension is enhanced by the vertiginous shots of New York's skyscrapers filmed at high angles from the ground, Ralph ends the duel. Inspired by verses from the Bible written on the side of the United Nations Building about beating swords into plowshares (Isa. 2:4), Ralph throws down his weapons and walks towards Ben unarmed. This echoes the use of non-violent protest by the mainstream of civil rights activism, which saw the moral authority that non-retaliation to violence could add to their movement. ${ }^{94}$ The white male could easily kill his rival but he throws his rifle down. Ralph and Sarah walk off hand in hand, and enigmatically she then takes Ben's hand. The last shot of the film contains the three characters walking off, with Sarah standing between the two men, and as is typical of the post-nuclear-war film genre in this era, the caption 'The Beginning' comes up. While highly ambiguous, many reviewers think this implies the start of a three-way sexual relationship, with said relationship affirming racial integration. ${ }^{95}$ Nama thinks that the extremity of the post-apocalyptic scenario works against the liberal, pacifist conclusion: 'Either way, orgiastic or voyeuristic, the film symbolically associates and affirms black-white integration with not only the end of civilization as we know it but also the beginning of an unusual set of sexual mores. ${ }^{96}$ For Nama, this film has a rather problematic view of desegregation if it depends upon America's virtual depopulation and a revolution in sexual relations. Acknowledging that he is speculating, Wachhorst argues the conclusion is a result of the studio's reluctance to 'marry Inger Stevens to a black' ${ }^{97}$ 
Given the theme of this chapter, it would be surprising not to follow Nama in hailing World as an idiosyncratic response to desegregation, with an ending that unsatisfactorily resolves the interracial sexual energies it releases earlier in the narrative. One could add evidence from earlier in the film to Nama's reading of Ralph and Benson's contest as 'a two-man race war'.$^{98}$ Ralph tells his competitor for Sarah's affection, 'you remind me of a guy named Snodgrass', a reference to a well-dressed white male manikin Ralph kept in his apartment for company. Keeping a pair of manikins to stave off the crushing feeling of being the last human being alive, Ralph's frustrations are targeted against Snodgrass. Initially protesting to the shop dummy, 'I'm lonely and you're laughing', Ralph hurls Snodgrass out of the apartment. His anger will not be contained: 'You look at me but you don't see me. Don't see me and you wouldn't care if you did. Out you go my friend. We've been together too long, and you've laughed at me once too often.' Ralph's rage at the manikin is phrased in a markedly similar way to the articulation of being black in twentiethcentury America, being unseen and an object of comedy. Ralph Waldo Ellison asserted it in the title of his seminal novel Invisible Man (1952), Du Bois used the rhetorical figure of the veil behind which African Americans lived their lives and James Baldwin stated that the white Northerner 'never sees Negroes. [...] Negroes are, therefore, ignored in the North'. ${ }^{99}$ Once more reading the film through Du Bois's 'The Comet', Darryl A. Smith makes the point that in the short story, before New York City is depopulated, the character of Jim is already alone because he is not acknowledged as living on the same planet by white New Yorkers. ${ }^{100}$ As in 'The Comet', the film uses the condition of post-apocalyptic New York to project the failure to recognize black American humanity in the present. The other subject of Ralph's anger, that black Americans were portrayed as comic fodder in America's entertainment media, is well documented, such as film scholar Donald Bogle's 1973 book Toms, Coons, Mulattoes, Mammies, and Bucks: An Interpretative History of Blacks in American Films. ${ }^{101}$ Ralph's anger at Snodgrass's supposed indifference to his existential condition suggests he has tapped deep-rooted fury at the historical experience of African America. When Ralph makes a connection between Benson and Snodgrass, Benson's position in the narrative is analogized to the white middle-class privilege that Ralph raged against in manikin form.

I am reluctant to endorse this reading too heartily. Ralph and Sarah's initially unconsummated relationship is explicitly conceptualized in the terms of segregationist 1950s America. But the development of Ralph and Benson's hostility is explicitly deracialized. Admittedly, Ralph's early attempt to step aside and let romance grow between the two white char- 
acters is presented as his belief that Benson and Sarah belong together in ways that he and Sarah did not. Absolutely, once combat is joined, the victory of one male by killing the other will have decisive implications for the racial makeup of America's future. But Benson tells Ralph, 'I have nothing against Negroes, Ralph. [...] We have only one problem, there are two of us and one of her.' Ralph has heard such liberal platitudes from the socially privileged race before - he responds, 'That's white of you' - but Belafonte's performance implies that Ralph accepts the absence of racial motivation in Benson's hostility. His willingness to be part of a triangular relationship at the film's end is barely plausible as it is - to think Ralph would do so believing Benson to be racist is an even greater stretch. Ralph's willingness to lay his weapon down may be addressed as much to the logic of nuclear deterrence as it is civil rights. He is inspired by the headquarters of that broker of international accord (at least in theory), the United Nations. World's narrative resolution - such as it is - may be re-read as a stance observable throughout the film, wherein the USA's readiness for nuclear war is perceived to be placing the country in great danger. Civil Defense measures are presented as childlike in their innocent faith in survival. As Ralph tries to enter Manhattan, the tunnels and bridges are jammed with the rusting cars of New Yorkers fleeing attack, mocking an adjacent Civil Defense poster that claims, 'Alert Today - Alive Tomorrow'. The ironic undercutting of confidence in Civil Defense is heightened by the camera focusing in on the poster's optimistic message. The most powerful scene in the film is when Ralph, considering himself the last human left alive, enters a New York radio station turned into a Civil Defense Headquarters and listens to the last broadcasts made in America. He hears that London, San Francisco and Chicago have been destroyed, that the order has been given for New York to be evacuated, and a radioactive poison dust cloud that is deadly for five days fell around the world after the nuclear attacks. The United Nations has ordered all nations to reconvene, but on the poisoned Earth there is 'no place to go'. For an entire two minutes, as the last broadcast is playing, the camera is fixed in the same shot following Ralph's face as he silently tries to stop his tears from flowing. This fixed shot allows the audience no onscreen distraction from the restrained emotion of Belafonte's performance. Focusing the audience's ears as well, the last words on the tape retain their awful dignity and profundity: 'Anybody there? Anybody?' Belafonte was well known as a peace activist who supported nuclear disarmament. ${ }^{102}$

In The World, The Flesh and the Devil, racial politics explicitly structure how Ralph and Sarah relate to each other and set psychological parameters on their desire to form a romantic dyad. Those racial politics seem 
relevant to the film's depiction of Benson's destructive competition with Ralph, but the narrative's argument that non-violence is the most effective way to maintain the peace is not only channelling the sensibility of civil rights. That narrative argument is also reflecting a sensibility that the USA's preparation for war in the form of constructing nuclear weapons and organizing Civil Defense are misguided acts of aggression that must be cast aside, as Ralph abandons his firearm, for the sake of humanity's continued existence. As such, The World, The Flesh and the Devil pre-empts the combination of antiracism and antideterrence posited by the black Atlantic figures discussed in the next chapter.

The racialized sexual codes of reproduction in The World, The Flesh and the Devil can be productively compared to those in the 1951 film Five, directed by Arch Oboler. Five was filmed and distributed before the major early events of the high civil rights period, such as the Supreme Court's 1954 rejection of segregated education in the Brown v. Board of Education of Topeka, Kansas ruling and the bus boycotts that began in Montgomery in 1955. ${ }^{103}$ The integration fantastically imagined in World is far removed from the narrative resolution in the earlier film, in which interracial tension is not overcome but erased. Five features a slightly larger group of nuclearwar survivors, and the two men fighting over the last (white) woman on Earth are both white - the black male character Charles does not figure as a possible suitor. Of the two white men, Eric and Michael, Eric is a racist who says it is a mistake Charles survived the attack, and he does not address him directly, calling Charles 'this one'. Echoing the rhetoric of segregation, Eric does not want to eat and sleep under the same roof as Charles and demands he be cast out of the house the survivors all live in. To detach audience allegiances from Eric, James Anderson's uneasy performance and the way he is lit in shots demonize his character. Eric secretly murders Charles and leaves the house with the last woman, Roseanne, and her newborn baby. Eric succumbs to the radiation that is still poisoning America's cities, and while Roseanne returns to the house, her baby dies. One could argue that the death of the baby symbolizes the death of future generations and therefore the demise of the human race, but the final shot of Roseanne and Michael (now the last male on Earth) suggests they will have children together: they lean in to each other's bodies in front of newly hoed farmland, and a quotation from Revelation praising 'all things new' (Rev. 21) is laid over this image. As opposed to the conclusion of The World, The Flesh and the Devil, where reproduction of the species and integration was linked, in Five the possibility of reproduction is more tentative and there is no suggestion that the future of humanity will be anything other than white. With the death of the racist Eric, racial antagonism 
may no longer exist in Earth's future, but the elimination of racial difference makes the construction of a tolerant, integrated community irrelevant, too.

Five was primarily filmed in director Arch Oboler's own home, the Cliff House designed by Frank Lloyd Wright. It is an amalgam of styles, simultaneously old-fashioned (rough concrete and wooden planking reminiscent of a frontier fort) and futuristic (striking odd angles). The characters have all travelled across America to this building, whose location in the hills shields it from radioactivity; its modernist shape suggests it belongs to the future and will carry the characters safely into that future through the deadly fallout. Against Eric's racism, Michael makes a speech where he expresses his desire for the house to become a harmonious community very different from the world that existed before the war: 'let's not make the mistakes they did, the millions of them. Let's work together, live together, like friends.' Thinking about the community Michael wants to build in the house, it is appropriate to consider the 1950s writer Van Wyck Brooks and his views on Wright's architecture:

In his essay 'Transnationalism', Van Wyck Brooks cites Frank Lloyd Wright's 'open plan in architecture as an appropriate example of what we might call 'melting-pot art forms' since it 'abolishes all the partitions that have divided room from room' in the same way the 'human laboratory' of America 'abolishes the barriers between man and man in the interest of a wide sociality and all-human freedom. Wright has translated Walt Whitman into architecture. ${ }^{104}$

This combination of the architecture of Frank Lloyd Wright, the American melting pot and surviving a nuclear war recurs in Philip Wylie's novel Triumph (1963; a 'condensed' version of the novel was published in the Saturday Evening Post on 2 February 1963). In Wylie's novel, millionaire Vance Farr has torn down his family home set on a Connecticut hill and replaced it with a new building, named Uxmal, complete with an extensive underground survival complex: 'they tore down the Victorian job, gazebos and all, and had one of that - what-was-his-name - that Frank Lloyd Wright's students - man of fifty, now - design their new house'. The abolition of boundaries Brooks identifies as characteristic of Wright's style is evident in Uxmal's living room, a long room with a glass exterior wall whose subdivision is effected by a recessed floor. Because it is set in the future, Triumph has to make Uxmal's designer a student of Wright rather than the architect himself, but the influence is apparent, with the low design of the building repeatedly described as 'modernistic' and 'Mayan'. ${ }^{105}$ As with the Cliff House, Uxmal aesthetically bridges the past and the future. 
These buildings protect their residents within their walls and preserve them safely through time and nuclear attack.

The 14 inhabitants of the underground complex in Triumph are suitably mixed in ethnic origin: Chinese American, Japanese American, Jewish American, Italian American, half Hispanic-half Irish American, African American and a handful of Anglo Americans - the Farr family trace their lineage back to the Puritans. Valerie Farr, the group matriarch, describes the assembled survivors as a microcosm of the USA's productive ethnic diversity: 'its perfectly miraculous, this group! A real League of Nations, yet everyone an American'. ${ }^{106}$ Her invocation of American identity as the connective tissue for a federation of nationalities echoes the model of 'Trans-National America' advocated by social theorist Randolph Bourne in 1916. Bourne opposed the melting-pot model because he saw its homogeneous Americanness as really being Anglo-Americanness. He hailed the distinctiveness of communities formed out of the Old World customs of immigrants and praised the interaction between members of discrete ethnic groups. For Bourne, this curiosity and open-mindedness towards different groups was characteristic of America's cosmopolitanism. ${ }^{107}$ Given Brooks's claims for Wright's architecture, it is striking that neither the Cliff House nor Uxmal successfully preserve their ethnically plural American communities in Five or Triumph. The pluralism of the Cliff House is eliminated by murder; the Uxmal house is destroyed in the nuclear strike, and the underground complex is unable to protect the survivors indefinitely. One wonders how mischievous Wylie is being when Valerie describes the group as a League of Nations, given the widely perceived bathetic status of that international organization, dismissed by Franklin D. Roosevelt as 'nothing more than a debating society and a poor one at that'. ${ }^{108}$

In terms of Triumph's portrayal of ethnic difference, the following example, taken from the Chinese-American character Lotus (Lodi) Li's diary, is paradigmatic:

'I used, not so much to envy, but sort of wistfully wonder what it was like to be one of those graceful, tall, blonde women that nineteenth-century novelists used to call "willowy." [Hispanic-IrishAmerican] Angelica is too shaped and too dark-haired to qualify, but [Anglo-American] Faith does. And I know what it is like to be like Faith.

'Not a bit different from being slant-eyed and Chinese! Or from being colored, like [African-American] Connie! ${ }^{109}$

The dramatic pause at the end of that third sentence mirrors the narration as a whole. It suggests that Lodi can only know what it means to be graceful 
and blonde vicariously, via her friend Faith Farr - but then it trumps that difference in the next sentence, asserting the identical experience of these female characters. Physical difference is not denied; its presence is conceded but rendered meaningless in terms of phenomenological being. Throughout the novel, the third-person narrator works hard to eliminate racial boundaries between the characters: inescapable differences are set up only to be revealed as surface prejudices obscuring essential human sameness.

As in Five, the character who wants to leave the dwelling and the multiracial community is a white male racist whose attenuated self-preservation impulse is an aspect of wider insanity. In Triumph, that character is Kit, and he romps away from the safety of the underground complex, shouting back to the Jewish-American hero Ben Bernman:

[You] and your scientist pals have a conspiracy! To keep us buried till we die! Jew, Chinese woman, Jap kid. You're taking a revenge on the white race. I'm fed up with those caves [...] So I'm going, as a test! When I get back, and when the gang sees how you've betrayed all of us, you'll be slaughtered, Mr. Jew Doctor Benvenuto Cellini Bernman and young [Japanese-American] George Hyama! Then we white poeple [sic] will all come out, and your crazy plot will be futile! $!^{110}$

His description of George and Ben's 'crazy' plot is deeply ironic and putting racism in the mouth of a madman is one means these texts have to discredit it. Kit's delusions are almost humorous, and his assured death ends his objections to the transnational American community. Beneath the ridiculousness, though, Kit's use of the word 'slaughtered' indicates an exterminatory desire. In this depopulated America, Kit wants to repopulate with white stock, and not only will the non-white members of the community be prevented from living with the white Americans, they will be removed from America's future.

Characters in Triumph proclaim nuclear weapons to be racially white technology, but as observed elsewhere in this study, nuclear war decentres white privilege around the world. Ben doubts that science can prove that any race possesses a 'special quality or superiority'; he thinks the only important difference is 'Environment, and the attitudes of other people to anyone, or to any minority group, regarded as "different" - and, of course, in consequence, as inferior'. Ben's interior monologue puts 'white men' in quotation marks to make dubious their status as a racial group, but he is in no doubt that people who have been incorporated (albeit uncertainly) into this category have committed historical crimes: the English and Spanish settlement of 
the Americas, the enslavement of Africans, the colonization of Asia and European anti-Semitism. For Ben, the racial arrogance of whites culminates in nuclear war: Old Testament references are used to suggest white North Americans and Europeans have died for their sins. The 'white man's world' has 'committed suicide', killing 'the helpless islands of the Japanese people', too. Labelling the white population of the Northern Hemisphere the 'bigoted billion', Ben suggests their 'world-conquering aspirations' sealed their fate. ${ }^{111}$ The genocide of nuclear war is a differently scaled version of Kit's white supremacism, the racial arrogance which led him to leave the safety of the shelter in an insane posture of invulnerability. Both are suicidal acts in Triumph's narrative. With white supremacism destroying itself, the novel is unequivocal that the post-apocalyptic Earth will grow into a more peaceful and racially egalitarian place than the preapocalyptic world that incubated the Cold War. The survivors beneath Uxmal are told over the radio that the parliaments of 'Australia and New Zealand [are] creating a world outfit [...] International government, of course'. This international ruling body will use hydrogen bombs to maintain the peace, and all the surviving nations have a stake: 'Everybody's coming in - the Latins, the African nations, Indonesia.' With such an inclusive international government, the existing power relations will look very different as 'men are to become free and equal' and the Australian speaker specifies what kind of freedom and equality will be enshrined in the future: 'Without racial differences. Took the extermination of half a world to bring it about. Worth it, though, perhaps, eh?' The 'federation of racially, nationally free and equal people ${ }^{\prime 12}$ the American survivors are joining is not the world they have left.

As the only Americans left alive, the country's future will be shaped by the survivors' selection of reproductive mates. Those decisions reveal the extent to which the novel's post-nuclear-war community is transnational - and which relationships touch an especially sore area of the racist imagination. The character of Connie Davey, an African-American woman, and her relationship with Pete Williams, an Anglo-American, lies at the ultimate limit of Triumph's liberal desegregationist vision. One such limit is the recurrent primitivism that filters the narration's depiction of Connie. She is portrayed as animalistic and stunningly beautiful, and her attractiveness seems to be an index of her feline muscularity. This is accompanied by her extraordinary intelligence and learning - physical power is matched by intellectual power. When she first enters the narrative, the short sentences mirror the calculating absorption of Ben as he takes in Connie's visual presence: 'A Negress. Tall, tawny-skinned, lithe, and striding, almost - yet with feral smoothness.' Her physical power seems in tension with 
her gracefulness, as it is when Connie is described by Vance Farr to Ben. Vance's fixated description is a glimpse of the effect her physicality has on men like him:

She had the body of a leopard, golden-brown, and just that taut, that alive. [She] became the most-chased young woman in this part of Connecticut - and many pursuers were older men, also - white, rich, and very respectable, except when they saw Connie. [...] On a glance, she makes ninety-five per cent of all men of all sorts and ages forget she is a Negress and concentrate on the fact she's a woman.

Connie can control her physicality, then, but most male observers cannot control their reaction to her - her animal power is irresistible. Vance's comments indicate that her race would usually be a bar to the older white 'respectable' men chasing her, but her feminine allure exceeds those social constraints (to take this portrayal at face value would mean ignoring the extensive evidence that black women in America were potent objects of white sexual desire during and since the era of plantation slavery). Ben's uneasy internal reaction to Vance's lurid perceptiveness makes the reader sceptical of the millionaire's statements, but the third-person narrator and Ben's thoughts validate Vance's infatuation. She is a 'nubile woman' possessing a 'feline, dark body, a black panther body'. The double lexical markers of her catlike-ness and her blackness are repeated from her earlier representation. Despite her composure and education, this physicality threatens to become savagery: Ben thinks of her as a 'calm, intelligent, highly-educated, yet feral woman'. ${ }^{113}$ Wildness and primitivism are constantly present in the adjectives used to describe her, threatening to undo her reason, as they do in the final part of this sentence that acts as a rebuttal ('yet') to her self-control and learning ('calm, intelligent, highlyeducated').

When Connie speaks for herself in Triumph, her evident calm rationality gives a different impression from the repeated descriptions of her as catlike and 'feral'. It is suggested that racialized sexual codes have forced her to self-reflect continually on her romantic relationships. Her growing attachment to Pete is no exception to this self-consciousness, leading Connie to draw back from the relationship. Not because of the absence of desire: 'Pete wants me. I want him. Only human.' According to Lodi, the pre-nuclear-war sexual codes have been transcended because Connie and Pete see each other's humanity rather than a skin colour: Pete has 'already forgotten he's white and she's black [...] when somebody doesn't remember color any more, that makes everything different'. Connie thinks this is possible because the underground community has been deracinated 
from American society and she withdraws from the romantic relationship because 'if we ever get back to humanity' she believes being re-immersed in racial codes would compel Pete to re-acknowledge his identity as a white American, an identity that would catastrophically collide with his love for her: 'a white man too close always feels he's too close - to a colored girl. I hate that. And that would smash up Pete'. ${ }^{114}$ The enclosure of the underground survival complex has meant freedom from society's racial codes, but if the survivors were restored to the society they knew before the war, physical liberty would come with claustrophobic social surveillance, and under that pressure Pete would buckle.

Seen through the pre-nuclear-war social codes of romantic coupling, Connie and Pete's relationship bears the greatest strain out of all the heterosexual relationships inside the underground complex. After the radio contact with Australia that proclaims the end of racism, Ben makes a concluding speech hailing the enormously increased probability of the pair living and loving together. The length of the speech (approximately oneand-a-half pages), its position as the last reported speech in Triumph, Ben's courage and humility (in summing up the group's achievements he omits his own acts of life-risking heroism) and it going uninterrupted all add to the moral authority of Ben's arbitration on the meaning of their survival. With this authority Ben interprets the disengagement of Connie and Pete's relationship as evidence, not of the absence of love, but of its profound affirmation: their actions were undertaken to avoid hurting each other in the future. The post-nuclear-war southern hemisphere represents a benign social environment for Pete and Connie, one where it 'seems at least possible' they can 'resume their love'. ${ }^{115}$ Triumph turns the ability of individual characters to love across the colour line into a principle that the world of the future will live by, using love as a counterpoint to the national and racial separatism that compels humans to assert their allegiance to descent-based identities. Love has operated in this manner in American culture for centuries: presenting the romantic bond between a man and a woman as a force of nature robs descent identities of their claims to naturalness. ${ }^{116}$ Ben's mantra is that the underground community has survived because of the characters' love; they 'have learned' the 'error' of the world that went to nuclear war, which is that it 'came to love things more than one another'. The narration leaves no doubt that the love for other humans prescribed to prevent another nuclear war is the equivalent of the love transcending racial and ethnic division that lies between several of the underground couples. Ben ends his speech by identifying the absence of this love in the USSR and the USA of the 1960s, committing himself 'to embody [love] always', and finally embracing Faith, the woman he had 
been reluctant to declare his love for before the war because he perceived their descent identities to be incompatible. ${ }^{117}$

The offspring of Faith and Ben and the other couples will be the Americans of the future - or they would be, if the community of survivors was to remain on (or beneath) American soil. The narrative ends with the survivors waiting to be airlifted out of the country by Australians. The transnational promise of intermixture and openness that Brooks saw in Frank Lloyd Wright's design might survive, but not on American soil (and the modernistic house itself has been destroyed in the war), as an Australian helicopter pilot ponders:

They were Yanks. Americans. Specifically, North Americans. Citizens of the United States. All who remained alive in that enormous nation.

[...] They would leave the United States of America forever.

And when they had gone, the place would have no name. ${ }^{118}$

The conclusion of Triumph seals the ongoing existence of humankind, yet melancholy supersedes hope as the overriding emotional mode. How does this emotion programme the reader when deciphering the new world that the survivors are entering? It turns a last-minute rescue into an elegy for the nation. The transnational community is airlifted off its hill, but the italicized 'were' signals the past tense of Americanness. The novel ends in mourning for the country that is about to stop existing. From Wylie's perspective in 1963, sacrificing America enabled a world where an AfricanAmerican woman and Anglo-American man would have a chance to love openly and in public.

\section{Breeding beyond the Species}

As hinted by the title of Ray Bradbury's 'The Other Foot' (from his 1951 collection The Illustrated Man), in this short story America's racial balance of power is reversed in the future. Following the exclusively black colonization of Mars and a subsequent nuclear war on Earth that leaves few survivors, the new inhabitants of the red planet become responsible for the preservation of non-black humankind. Initially, it seems the nuclearwar survivors (and by corollary, a multiracial humankind) will be saved and brought to Mars, but with the white nuclear-war survivors subjected to segregation and lynching. The narrative of 'The Other Foot' eventually avoids this future, and as in Triumph, harmonious interracial social relations become possible because the USA has been atomized beyond recognition.

In 'The Other Foot', the black population of Earth 'just up and walked 
away and came to Mars' in the mid-1960s, migrating to a place free of racial persecution. An exodus of African Americans en masse to Mars to escape lynching and economic servitude also featured in Bradbury's earlier The Martian Chronicles (1950). In that instance, the migration was not racially exclusive, although, as in 'The Other Foot', it is almost immediately followed by nuclear war on Earth. In the latter story, 'the Chinese and the Indians and the Russians and the British and the Americans' fight a nuclear war into the mid-1980s; a year after the war's conclusion, the 'five hundred thousand' survivors, of 'all kinds and types', are able to salvage 'enough metal to build [...] one rocket'. A small group flies to Mars, where their presence has some novelty value, since 'no white men've come up' to the planet since the black population migrated there. ${ }^{119}$ The two protagonists of the narrative, Hattie and her husband Willie, rush to be at the landing site when the rocket lands, and Willie accurately predicts that with Earth wrecked beyond repair, the survivors have sent an advance party to ask the new Martians for sanctuary and assistance in ferrying the last Earthlings off the planet. Exactly how this parley will be resolved is the narrative tension at the centre of Bradbury's short story, since Willie and other new Martians are preparing to instate a system of segregation resembling that of the United States, but inverted. Willie tells Hattie that white people

can come up and live and work here [...] All they got to do to deserve it is live in their own small part of town, the slums, and shine our shoes for us, and mop up our trash, and sit in the last row in the balcony. [...] And once a week we hang one or two of them. Simple. ${ }^{120}$

Willie prepares to greet the first white man to emerge from the rocket by readying his lynching rope (his murderous impulse is made more understandable because on Earth his father was lynched and his mother was shot). A thin, trembling white man addresses the crowd from the rocket, conceding that the humans who stayed on Earth have been stupid and evil, and that in exchange for being 'taken in' the nuclear-war survivors will 'do the things you did for us - clean your houses, cook your meals, shine your shoes, and humble ourselves in the sight of God for the things we have done over the centuries to ourselves, to others, to you'. Bradbury elongates the tension by stretching the ensuing silence and hesitation over several paragraphs. Hattie is desperate to turn Willie away from his homicidal wrath and she interrupts the silence with questions concerning Greenwater, Alabama, the town they lived in on Earth. The white man reports that Greenwater has been destroyed in the nuclear war, so the 
spaces that symbolized racist violence to Willie - the tree where his father was hanged and the shack where his mother was shot - no longer exist. Without their presence to anchor the memory of his parents' murders in the physical environment, and knowing that the 'big-pillared houses' of white privilege have also been 'ripped into confetti', Willie has nothing left to hate; the landscape of the United States cannot be invested with the psychic trace of past atrocities if the country is an unrecognizable wasteland. Willie, acting as a spokesperson for the new Martians, drops his rope and tells the visitors they will not have to toil as a racially segregated underclass. When Willie states, 'everything's even. We can start all over again, on the same level', his choice of imagery suggests a newly discovered social parity between the races and the sense of living in a universe of undifferentiated horizontal space. In Willie's reading of the situation, African Americans had not been at home in segregated America; after the nuclear war, 'the white man's [...] got no home' either, and from that shared experience of homelessness and loneliness different races can be equal on Mars. ${ }^{121}$

Extending the theme of outer-space colonization and racial tension, the final section of Walter M. Miller Jr's A Canticle for Leibowitz (published as a novel in 1959 but released in serial forms earlier in the 1950s) is set long after a nuclear war. Humankind has rebuilt itself to the point where it can use nuclear weapons again, and with the threat of a second nuclear war growing in likelihood, different racial groups compete to colonize outer space. After the Asian Coalition sends 'the first colony ship' into orbit, competitors in the West protest, "Are we to let the "inferior" races inherit the stars?' To demonstrate their racial superiority, 'black people, brown, white, and yellow people' launch their own 'colonies'. Casting a satirical shadow over the competition between races on the colony planet, geneticists point out that 'since each racial group was so small' it was necessary for their descendants to intermarry to avoid 'deteriorative genetic drift due to inbreeding'. Interracial competition spurs outer-space colonization but interracial reproduction becomes a prerequisite of survival. ${ }^{122}$ Sharp appreciates this novel as 'a strong critique of contemporary American society' and, like the 'wry' geneticists in Canticle, the novel invites readers to mock the failed ambitions of race supremacists in the 1950s as well as in the future. In its narrative, the decision-makers at state level cannot preserve the human race on Earth, let alone the interests of the race they avow to promote. If humankind is to survive, it is - by genetic necessity - forced to 'cross-breed', a metaphor for the necessity of 'racial tolerance and cooperation'. ${ }^{123}$

'Cross-breeding' as a metaphor for interracial cooperation is part of the 
texture of Dawn (1987), the first in the Lilith's Brood series of novels (originally entitled the Xenogenesis trilogy) by African-American SF writer Octavia E. Butler. Dawn's post-nuclear-war future slides the metaphor used in Canticle over to humans breeding with an alien species. The extraterrestrial Oankali have saved the human survivors of World War Three and placed them in suspended animation. The humans are being awakened slowly, and Dawn's protagonist, Lilith Iyapo, has been chosen to assist other human beings in acclimatizing to the interspecies breeding planned by the Oankali. In relation to Dawn, Sherryl Vint is right to suggest all of Butler's novels can be read as neo-slave narratives. One could certainly see the novel's dramatic scenario as an allegory for the dilemma faced by the transplanted New World slave population and their descendants. Lilith has been permanently separated from her first family and physically removed by her captors into a realm they control, and the Oankali intend to coerce Lilith into procreating with them. Growing to accept these terms of survival, Lilith must 'build' a 'livable future' with the 'former oppressors' ${ }^{124}$ What I want to do here is consider how the questions confronting Lilith connect racial and gender distinctions to the heightened nuclear consciousness of the 1980s. Butler uses the relationship between human and Oankali to dramatize debates about living with difference: once again the question 'how far can one live with difference?' is translated into the question 'with whom will one reproduce?' And once again, the answer to that last question holds a clue to the future of humankind. Those questions are immediately suggested by the first name of the main character in Dawn. Lilith's name is borrowed from the first woman in Judaic folklore, who preceded Eve as Adam's wife. Lilith was made at the same moment as Adam but she refused to obey his authority. She left Eden and mated with demons, the devil or an archangel, depending on the version of the tale, and the mythical Lilith's procreation of a monstrous race outside humankind is an evident reference point for the dilemma faced by Butler's Lilith. ${ }^{125}$

In the essay 'The Monophobic Response' (1995), Butler writes of a human need 'to create aliens' that stems from our inability 'to get along with those aliens who are closest to us' - other humans. She states the desire for division, 'dominance, and exclusivity' enacted in the 'terrible sibling rivalry going [on] within the human family' is expressed through the creation of extraterrestrials. ${ }^{126}$ Butler uses extraterrestrial-human encounters in Dawn to reflect back on human division and hierarchy, drawing attention to this tendency rather than sublimating it into a fascination with outer-space aliens. An explicit theme of the novel is the harm done when the need for 'dominance' is ignored rather than seeing it as an 
evolutionary inheritance stretching back to the first humans.

Dawn feeds off the antinuclear sentiment that ran high during the 1980s and the renewed tension between the USSR and the USA in the first half of that decade. The nuclear belligerency of President Reagan compelled Butler to interrogate flaws in the species:

During the early part of the Reagan era, there were people who thought we could win a nuclear war and rid ourselves of the Soviet Empire. I thought they were nuts, but they were there. And Reagan got into office in spite of the fact that he thought a nuclear war was winnable. [...] I got my idea for the Xenogenesis books (Dawn, Adulthood Rites and Imago) from Ronald Reagan because he was advocating this kind of thing. I thought there must be something basic, something really genetically wrong with us if we're falling for this stuff. ${ }^{127}$

Jonathan Scott does not see the difference between 'black' and 'white' in Butler's work as a natural distinction but as a boundary drawn to demarcate social blocs; as such, 'white racial oppression is about social control, not phenotype'. ${ }^{128}$ Butler's interview is not incompatible with Scott's conceptualization of racial difference here, but following her line of thought, the construction of racial difference in the Lilith's Brood trilogy does appear to be an example of a 'genetic' human inclination to organize human individuals and groups into hierarchies. This is best seen in Dawn in the dialogue between Lilith and Jdahya, one of the Oankali:

'You have a mismatched pair of genetic characteristics. Either alone would have been useful, would have aided the survival of your species. But the two together are lethal. It was only a matter of time before they destroyed you.' [...] 'You are intelligent', he said. 'That's the newer of the two characteristics, and the one you might have put to work to save yourselves. You are potentially one of the most intelligent species we've found [...] You are hierarchical. That's the older and more entrenched characteristic. We saw it in your closest animal relatives and in your most distant ones. It's a terrestrial characteristic. When human intelligence served it instead of guiding it, when human intelligence did not even acknowledge it as a problem, but took pride in it or did not notice it at all [...] That was like ignoring cancer. I think your people did not realize what a dangerous thing they were doing.' ${ }^{129}$

Hierarchical thinking produced the racism of the novel's past, and, as Jdahya's comments indicate, when intelligence is placed in the service of hierarchical thinking, weapons that can shatter a planet are built and used. 
Butler explains she chose a nuclear war because it evidences the dangerousness of this tendency to think of oneself as superior to others: 'I put this [debate about humans' inherited characteristics] after the big war because it's kind of an example. We've one-upped ourselves to death, just our tendency to one-up each other as individuals and groups, large and small.' ${ }^{130}$ For the character Tate in Dawn, who believes in an 'original sin' model of human nature, nuclear war was inevitable: 'Human beings are more alike than different - damn sure more alike than we like to admit. I wonder if the same thing wouldn't have happened eventually, no matter which two cultures gained the ability to wipe one another out along with the rest of the world.'131

Perhaps to avoid the obvious defeatism to which this Weltanschauung could lead - that war and racism can be ameliorated but never eliminated - Jdahya adds, 'It isn't simple, and it isn't a gene or two. It's many - the result of a tangled combination of factors that only begins with genes.' Butler blends human nature and social organization in explaining why the world slips into nuclear war, seemingly using the Oankali as a mouthpiece for her own views. When Lilith asks whether humans 'were genetically programmed to do what we did, blow ourselves up', Jdahya's explanation parallels humanity's genetic inheritance to the cancer cells the Oankali removed from Lilith. The cancer, part of Lilith's inherited disposition, is small and once discovered can be 'cured'. 'But', Jdahya asks her, 'what if you hadn't recognized the significance of your family history? What if we or the humans hadn't discovered the cancer?' Lilith's answer - that it would have killed her - is the key to understanding humanity's fate. 'If [humankind] had been able to perceive and solve their problem, they might have been able to avoid destruction. Of course, they too would have to remember to re-examine themselves periodically. ${ }^{\prime 32}$ Humanity was unable to use its intelligence to identify the will to be superior and therefore was unable to isolate that tendency from the social body. In Jdahya's metaphor this tendency cannot be eradicated decisively because it is part of our humanity. But constant vigilance can prevent it damaging and killing, a constant vigilance informed by collective memory of this inheritance.

Several examples in the novel indicate how this inheritance - referred to as the 'Human Contradiction'133 - leads to suspicion, violence and death. The reactions to Joseph and Lilith's relationship suggest hierarchy and prejudice remain hardwired into the human psyche. Joseph is a Canadian of East Asian descent, and unpleasantly familiar forms of homophobia and racism secretly circulate against him: an Oankali reports, 'there are already two human males speaking against him, trying to turn others against him. 
One has decided he's something called a faggot and the other dislikes the shape of his eyes.' Lilith explicitly says the tensions rising between the human survivors are comparable to the spirit of violence that pitted the superpowers against each other. 'It's like "Let's play Americans against the Russians. Again."' Curt Loehr, a New York cop, embodies the desire for hierarchy when he leads a splinter group of humans away from Lilith and Joseph's group. The Oankali alter Lilith and Joseph's DNA so they can heal more quickly, and fearing this regenerative ability, Loehr hacks Joseph's head off. Through free indirect discourse, Lilith calls this an act of 'Insanity!' which connects Joseph's murder to the nuclear war, something she refers to as 'an insane act'. ${ }^{134}$

Dawn can be usefully read alongside the public debate taking place on the other side of the Atlantic in the 1980s. In The Meaning of Conservatism (1980), the British conservative philosopher Roger Scruton wrote that people naturally seek the company of those who resemble themselves. Scruton defends 'Britons [who] feel strongly about something which was once called "the alien wedge" [of immigrant communities]'. He argues that the sentiments of such Britons 'involve natural prejudice, and a desire for the company of one's kind. That is hardly sufficient grounds to condemn them as "racist". ${ }^{135}$ Similarly, Ray Honeyford stated in the collection AntiRacism: An Assault on Education and Value (1986) that 'prejudice' is acceptable when it means 'no more than a preference for one's own kind'. ${ }^{136}$ The other humans' hostility to Joseph and Lilith might be more evidence of what Scruton calls 'natural prejudice' - presumably, an inborn preference for people who are similar to us. As G. A. Cohen notes, though, the language used by Scruton and Honeyford is vague: what does 'one's kind' mean? Butler uses the relationship between Joseph and Lilith to underscore one of Dawn's main points: sameness takes place on several levels beyond that of physiology. By doing so, Butler talks back to the preference for 'one's kind' that Scruton and Honeyford expressed in terms of race. ${ }^{137}$ In Dawn, preference for sameness does not only mean physical resemblance - it can mean a shared set of values. Before they awakened Lilith's human companions, one of the Oankali thought she 'would choose one of the big dark ones [i.e. an Afro-Caribbean male]' as her romantic partner 'because they're like you [in appearance]'. Jdahya, however, thought she would choose Joseph for the same reason: 'During his testing, his responses were closer to yours than anyone else I'm aware of. He doesn't look like you, but he's like you.'138 Reconciliation, then, is not the best way to describe the politics of difference being worked through in Dawn. What readers are asked to consider is the recognition of sameness that coexists with physical dissimilarity. 
Meditating on coming to terms with difference - and not seeing difference as inferiority, that deadly human inheritance - Dawn is hopeful that even when repugnance is the immediate emotional response, a shared set of terms will be recognized by both parties, from which solidarity of objectives can be formed. The narrative of the novel implies this process in the journey that Lilith makes, from recoiling against the Oankali, to suspicion over their intentions, to empathizing with their values, and finally to committing herself to the extraterrestrials' vision of the future against those humans who cannot sever their repulsion. Near the start of the narrative, the novel uses a series of extended accounts to convey her slow, difficult process of tolerating their Otherness:

She awoke abruptly, twisting around to look at him. He was still on the platform, his position hardly altered. When his head tentacles swept in her direction she got up and ran into the bathroom. He let her hide there for a while, let her wash and be alone and wallow in self-pity and self-contempt. She could not remember ever having been so continually afraid, so out of control of her emotions.

The force of this reaction is made so strong in order for the reader to see the instinctual repulsion Lilith must overcome. Lilith describes what she is experiencing as a 'true xenophobia',139 and in intertwining desire and repulsion her 'ambivalence exactly echoes the psychic structure of racism'. Luckhurst reads Lilith's complex emotional response to the Oankali and her situation (a residue of resentment lingers throughout the trilogy) in terms of Butler's entire oeuvre and the moral responsibility that surrounds her conceptualization of hybridity. Luckhurst wants to avoid calling Butler's work 'hybrid' because of that term's celebratory associations - the 'automatic utopianism' bound up in its usage. Butler's engagement with hybrid states is never easy or euphoric; it is morally conflicted and subject to a barrage of emotional responses. How could it be otherwise, when Butler's SF and its depiction of biological intermixture constantly thematizes how twentieth-century cultural hybridity has so often been arrived at as a legacy of slavery and colonialism? Luckhurst usefully terms Butler's writing as 'miscegnate fictions', defining her work in relation to the political and historical contexts that considered racial intermixture to be horrifying and wrong. Butler understands that the influence of those contexts makes sanctifying the figure of the hybrid simplistic, and lacking the moral power that comes from acknowledging the much more complicated history addressed by her miscegnate fictions. ${ }^{140}$ As part of this complexity, the human Paul Titus sees interspecies breeding as a form of genocide for terrestrial humans: 'When they're finished with us there 
won't be any real human beings left. [...] What the bombs started, they'll finish.' Alternatively, Jdahya calls it 'trade', an exchange promising to enrich both parties. ${ }^{141}$ Lilith aligns herself with the project to repopulate the Earth with a mixed species. She retains reservations, but after seeing the murderous ramifications of the Human Contradiction, 'human nature [...] does not appear to be particularly worthy of preservation'. ${ }^{142}$

The narrative presents the Oankali and humans as having elective affinities that promise a greater future than antagonism built on physical difference. There is, however, a perceptual gap between the Oankali's perception of nuclear war and the norms of Cold War deterrence that serves Dawn's antinuclear politics. The interpretation of a different species makes the illogic of nuclear war come into relief. They tell Lilith they believed 'that there had been a consensus among you, that you had agreed to die'. Even after they gain an understanding of the Cold War context that led to nuclear war, it remains distant and inassimilable to thought. There is a degree of irony in this physically abhorrent extraterrestrial professing that nuclear stockpiling was 'Frighteningly alien'. Their alterity to the historical context that made nuclear war legible is analogous to Lilith's personal politics, and she tells them, 'Yes. I sort of feel that way myself, even though they're my people. It was [...] beyond insanity.' Their shared incredulity at the people of Earth's willingness to accept the threat of nuclear war reinforces the differing notions of likeness presented by Dawn: one may be like the people who share one's outlook on the world, rather than being like people closest to one's physiological constitution. The Oankali's interpretation of nuclear war as species suicide mirrors Lilith's earlier reflection on the event, that a 'handful of people tried to commit humanicide. They had nearly succeeded..$^{143}$

Dawn reflects on the need to acknowledge sameness against the inclinations of the Human Contradiction. Various examples connect the humans' fear of the Oankali to the terrestrial prejudices of homophobia and racism (these connections become more explicit later in the Lilith's Brood trilogy ${ }^{144}$ ), and to the destruction of nuclear war. Focalized through Lilith, the novel tracks how the end of the species is worth pursuing, not the end of the species in World War Three but through interbreeding with aliens. The behaviour of various humans in the narrative indicates that the permanent transformation of human nature may mitigate the Human Contradiction, and as such, should not be feared. Indeed, although humans are encouraged into relationships with aliens in the novel, it appears that the lessons learnt in this post-apocalyptic world are applicable to combat the forces of racism at work in twentieth-century America, where strong prohibitions have policed love and procreation outside one's racial or 
ethnic group. Dawn's combination of antiracism and antinuclear activism is one used again and again by writers, thinkers and performers from the black Atlantic to scrutinize the direction Western modernity was taking, as explored in the next chapter.

\section{Notes}

1. Keith Shocklee, Eric Sadler and Carlton Ridenhour, 'Fear of a Black Planet', in Public Enemy, Fear of a Black Planet, Def Jam Recordings, New York (1990).

2. Quoted in Cooper, 'The Whiteness of the Bomb', p. 81.

3. For an extended discussion of images of the globe and the nuclear threat, see Robert Jacobs, 'Target Earth: The Origins of the Image of the Whole Earth in the Ashes of Hiroshima and Nagasaki', in Robert Jacobs (ed.), Filling the Hole in the Nuclear Future: Art and Popular Culture Respond to the Bomb, Lexington Books, Lanham, MD (2010).

4. Cordle, States of Suspense, p. 5. See also Paul Brians, Nuclear Holocausts: Atomic War in Fiction, 1895-1984, Kent State University Press, Kent, OH (1987), p. 60 .

5. Sollors, Neither Black nor White Yet Both, p. 43.

6. W. E. B. Du Bois, The Souls of Black Folk (1903), Vintage and Library of America, New York (1990), p. 12.

7. Sollors, Neither Black nor White Yet Both, pp. 112-41, 402-404.

8. Claude Lévi-Strauss, The Elementary Structures of Kinship (1949), Beacon Press, Boston (1969), p. 10.

9. Sollors, Neither Black nor White Yet Both, pp. 43-45, 395-410.

10. Sollors, Neither Black nor White Yet Both, p. 61.

11. Sollors, Neither Black nor White Yet Both, pp. 131-32; Nye, The Origins of Crowd Psychology, pp. 42-43.

12. Sollors, Neither Black nor White Yet Both, pp. 133-35.

13. Sollors, Neither Black nor White Yet Both, p. 45.

14. Fanon, Black Skin, White Masks, p. 72.

15. James Baldwin, 'Nobody Knows My Name: A Letter from the South' (1959), in idem, The Price of the Ticket: Collected Non-Fiction, 1948-1985, St Martin's Press, New York (1985), p. 189.

16. See Donald Bogle, Toms, Coons, Mulattoes, Mammies, $\theta$ Bucks: An Interpretive History of Blacks in American Films (3rd edn), Roundhouse, Oxford (1994), pp. 13-14.

17. Fanon, Black Skin, White Masks, p. 177.

18. Richard Godden, 'William Faulkner', in Richard Gray and Owen Robinson (eds), A Companion to the Literature and Culture of the American South, Blackwell, Malden, MA (2004), p. 444.

19. W. J. Cash, The Mind of the South, Thames and Hudson, London (1971), p. 89.

20. Godden, 'William Faulkner', p. 444.

21. Brogan, The Penguin History of the USA, p. 479. 
22. Frederic Brown and Mack Reynolds, 'Dark Interlude' (1951), in Allen deGraeff (ed.), Humans and Other Beings, Collier, New York (1963), quoted in James, 'Yellow, Black, Metal and Tentacled', pp. 37-38.

23. Gilroy, Against Race, p. 344.

24. Andrew Macdonald, The Turner Diaries (1978), Barricade Books, Fort Lee, NJ (1996), p. 52.

25. Werner Sollors, Beyond Ethnicity: Consent and Descent in American Culture, Oxford University Press, New York (1986), p. 166.

26. Israel Zangwill, The Melting-Pot, Macmillan, New York (1909), p. 33.

27. See J. Hector St John de Crèvecoeur, Letters from an American Farmer (1782), Oxford World's Classics, Oxford (2009), p. 44.

28. Sollors, 'Foreword: Theories of American Ethnicity', p. xxvii.

29. Sollors, Beyond Ethnicity, p. 72.

30. Dean MacCannell, 'Baltimore in the Morning... After: On the Forms of Post-Nuclear Leadership', Diacritics, 14.2 (Summer 1984), pp. 40, 42; Kenneth T. Jackson, Crabgrass Frontier: The Suburbanization of the United States, Oxford University Press, New York (1985), pp. 241-42, 289-90; Clifford Edward Clark Jr, The American Family Home 1800-1960, University of North Carolina Press, Chapel Hill (1986), p. 231.

31. MacCannell, 'Baltimore in the Morning... After', pp. 43-44.

32. Jackson, Crabgrass Frontier, p. 249. See also Preston, 'Protect and Survive', p. 474.

33. Sharp, Savage Perils, p. 207; Preston, 'Protect and Survive'.

34. MacCannell, 'Baltimore in the Morning... After', pp. 40, 45.

35. McConachie, American Theater in the Culture of the Cold War, p. 231.

36. Bernard Wolfe, Limbo, Random House, New York (1952), pp. 8: 92-93, quoted in Bartter, 'Nuclear Holocaust as Urban Renewal', p. 149.

37. Seed, 'Mapping the Post-Nuclear Landscape', p. 67.

38. Jacqueline R. Smetak, 'Sex and Death in Nuclear Holocaust Literature of the 1950s', in Nancy Anisfield (ed.), The Nightmare Considered: Critical Essays on Nuclear War Literature, Bowling Green State University Popular Press, Bowling Green, OH (1991), p. 23; Jacqueline Foertsch, “Extraordinarily Convenient Neighbors": African-American Characters in White-Authored Post-Atomic Novels', Journal of Modern Literature, 30.4 (Summer 2007), p. 124; Richard A. Schwartz, 'Family, Gender, and Society in 1950s American Fiction of Nuclear Apocalypse: Shadow on the Hearth, Tomorrow!, The Last Day, and Alas, Babylon', Journal of American Culture, 29.4 (Dec. 2006), p. 410.

39. Philip Wylie, Tomorrow! (1954), University of Nebraska Press, Lincoln, NE (2009), pp. 272-73.

40. Sharp, Savage Perils, pp. 200-202.

41. Wylie, Tomorrow!, pp. 270, 366-69.

42. Sharp, Savage Perils, pp. 199-200, 202-204; Foertsch, “Extraordinarily Convenient Neighbors"', p. 131; Smetak, 'Sex and Death in Nuclear Holocaust Literature of the 1950s', p. 23.

43. Sharp, Savage Perils, p. 203.

44. Wylie, Tomorrow!, pp. 370-71.

45. Wylie, Tomorrow!, pp. 161-62. 
46. Sharp, Savage Perils, p. 200.

47. Wylie, Tomorrow!, pp. 76, 158-59.

48. Smetak, 'Sex and Death in Nuclear Holocaust Literature of the 1950s', p. 23. See also Schwartz, 'Family, Gender, and Society in 1950s American Fiction of Nuclear Apocalypse', p. 413.

49. Wylie, Tomorrow!, pp. 107, 149.

50. William Javier Nelson, 'Racial Definition: Background for Divergence', Phylon, 47.4 (1986), quoted in Sollors, Neither Black nor White Yet Both, pp. 24850 .

51. Wylie, Tomorrow!, pp. 33, 341, 343, 28-29.

52. See Arthur Miller, Death of a Salesman (1949), Penguin, New York (1976), p. 49.

53. Wylie, Tomorrow!, pp. 319, 343.

54. Schwartz, 'Family, Gender, and Society in 1950s American Fiction of Nuclear Apocalypse', p. 422.

55. Foertsch, “Extraordinarily Convenient Neighbors"', p. 131.

56. Smetak, 'Sex and Death in Nuclear Holocaust Literature of the 1950s', p. 23; Foertsch, "Extraordinarily Convenient Neighbors"', p. 124; Schwartz, 'Family, Gender, and Society in 1950s American Fiction of Nuclear Apocalypse', p. 410.

57. Pat Frank, Alas Babylon (1959), Pan, London (1961), p. 19.

58. Frank, Alas Babylon, pp. 50, 111 . See also pp. 131, 134, 145-46.

59. Ward Moore, 'Lot' (1953), in Walter M. Miller, Jr and Martin H. Greenberg (eds), Beyond Armageddon, University of Nebraska Press, Lincoln, NE (2006), p. 82.

60. Frank, Alas Babylon, pp. 16-17, 94. See Bartter, 'Nuclear Holocaust as Urban Renewal', p. 152.

61. Cordle, States of Suspense, p. 5.

62. Frank, Alas Babylon, pp. 199, 225, 255, 230-31, 240.

63. Frank, Alas Babylon, pp. 26, 48.

64. Sharp, Savage Perils, p. 216; Foertsch, “Extraordinarily Convenient Neighbors"', p. 132.

65. Frank, Alas Babylon, pp. 173, 269, 265-66.

66. Bartter, 'Nuclear Holocaust as Urban Renewal', p. 151.

67. Cordle, States of Suspense, p. 5.

68. James Snead, White Screens / Black Images: Hollywood from the Dark Side, ed. Colin McCabe and Cornell West, Routledge, New York (1994); Foertsch, “"Extraordinarily Convenient Neighbors"', p. 125.

69. Frank, Alas Babylon, pp. 205, 137-38.

70. Smetak, 'Sex and Death in Nuclear Holocaust Literature of the 1950s', p. 23; Foertsch, “"Extraordinarily Convenient Neighbors"', pp. 132-34.

71. Frank, Alas Babylon, p. 47.

72. James Baldwin, 'Fifth Avenue, Uptown: A Letter from Harlem' (1960), in idem, The Price of the Ticket: Collected Non-Fiction, 1948-1985, St Martin's Press, New York (1985), p. 213.

73. Sharp, Savage Perils, p. 217; Foertsch, “"Extraordinarily Convenient Neighbors"', p. 134. 
74. Sharp, Savage Perils, p. 215.

75. Frank, Alas Babylon, pp. 215-16, 163-64, 91.

76. Sharp, Savage Perils, p. 217.

77. Frank, Alas Babylon, p. 283.

78. Seed, 'Mapping the Post-Nuclear Landscape', p. 68; Bartter, 'Nuclear Holocaust as Urban Renewal', p. 151.

79. Frank, Alas Babylon, pp. 11, 143.

80. Frank, Alas Babylon, pp. 181-82.

81. Frank, Alas Babylon, pp. $21,184$.

82. Frank, Alas Babylon, pp. 185-89, 270, 237.

83. Frank, Alas Babylon, p. 187.

84. Foertsch, “Extraordinarily Convenient Neighbors"', p. 135. Schwartz reads the radiation-blackened skin as a mark of Rita's sexual immorality more generally. Schwartz, 'Family, Gender, and Society in 1950s American Fiction of Nuclear Apocalypse', p. 419.

85. Frank, Alas Babylon, pp. 143, 232, 184, 237.

86. Schwartz, 'Family, Gender, and Society in 1950s American Fiction of Nuclear Apocalypse', p. 419.

87. Schwartz, 'Family, Gender, and Society in 1950s American Fiction of Nuclear Apocalypse', p. 420.

88. Frank, Alas Babylon, pp. 52, 184, 14.

89. Chris Ware, Jimmy Corrigan: The Smartest Kid on Earth, Pantheon, New York (2000). This graphic novel is largely unpaginated.

90. W. E. B. Du Bois, 'The Comet', in idem, Darkwater: Voices from within the Veil (1920), Schocken Books, New York (1969), pp. 259-60, 268-69, 273.

91. Adilifu Nama, Black Space: Imagining Race in Science Fiction Film, University of Texas Press, Austin (2008), p. 44.

92. Wachhorst, 'The Days After', p. 180.

93. Nama, Black Space, p. 45.

94. Nama, Black Space, p. 45.

95. For example, Phil Hardy (ed.), The Aurum Film Encyclopedia: Science Fiction, Aurum Press, London (1984), p. 193.

96. Nama, Black Space, p. 47.

97. Wachhorst, 'The Days After', p. 180.

98. Nama, Black Space, p. 45.

99. Du Bois, The Souls of Black Folk, pp. 3, 8; Baldwin, 'Fifth Avenue, Uptown', p. 213.

100. Darryl A. Smith, 'Droppin' Science Signification and Singularity in the Metapocalypse of Du Bois, Baraka, and Bell', Science Fiction Studies, 34.2 (July 2007), p. 208.

101. Especially Bogle, Toms, Coons, Mulattoes, Mammies, $\theta$ Bucks, pp. 19-24.

102. Abby J. Kinchy, 'African Americans in the Atomic Age: Postwar Perspectives on Race and the Bomb, 1945-1967', Technology and Culture, 50.2 (April 2009), p. 313.

103. Manning Marable, Race, Reform, and Rebellion: The Second Reconstruction in Black America, 1945-1990 (2nd edn), University Press of Mississippi, Jackson, MS (1991), pp. 40-42. 
104. Quoted in Sollors, Beyond Ethnicity, p. 257.

105. Philip Wylie, Triumph (1963), University of Nebraska Press, Lincoln, NE (2007), pp. 4, 15, 3.

106. Wylie, Triumph, p. 98; italics in original.

107. Randolph Bourne, 'Trans-National America' (1916), in Paul Lauter (gen. ed.), The Heath Anthology of American Literature (4th edn, vol. II), Houghton Mifflin, Boston (2002), pp. 1716-19, 1724.

108. Quoted in Brogan, The Penguin History of the USA, p. 575.

109. Wylie, Triumph, pp. 244-45.

110. Wylie, Triumph, p. 249.

111. Wylie, Triumph, pp. 189-90; italics in original.

112. Wylie, Triumph, pp. 269-71.

113. Wylie, Triumph, pp. 20, 70, 232-33.

114. Wylie, Triumph, pp. 233, 154.

115. Wylie, Triumph, pp. 274-75.

116. Sollors, Beyond Ethnicity, pp. 166-67.

117. Wylie, Triumph, p. 275.

118. Wylie, Triumph, p. 277.

119. Ray Bradbury, 'The Other Foot', in idem, The Illustrated Man (1951), Corgi, London (1974), pp. 28, 34-36.

120. Bradbury, 'The Other Foot', p. 30.

121. Bradbury, 'The Other Foot', pp. 36-38.

122. Walter M. Miller Jr, A Canticle for Leibowitz (1959), Orbit and Time Warner, London (1993), pp. 317-18.

123. Sharp, Savage Perils, p. 213; Miller, Canticle for Leibowitz, pp. 317-18.

124. Sherryl Vint, “Only by Experience”: Embodiment and the Limitations of Realism in Neo-Slave Narratives', Science Fiction Studies, 34.2 (July 2007), p. 256.

125. Roger Luckhurst, "Horror and Beauty in Rare Combination": The Miscegnate Fiction of Octavia Butler', Women: A Cultural Review, 7.1 (Spring 1990), p. 35.

126. Octavia E. Butler, 'The Monophobic Response' (1995), in Sheree Thomas (ed.), Dark Matter: A Century of Speculative Fiction from the African Diaspora, Aspect and Time Warner, New York (2000), pp. 415-16.

127. Octavia E. Butler, 'Interview with Joshunda Sanders' (2004), In Motion Magazine, available at http://www.inmotionmagazine.com/ac04/obutler.html (last accessed August 2010).

128. Jonathan Scott, 'Octavia Butler and the Base for American Socialism', Socialism and Democracy, 20.3 (Nov. 2006), p. 116.

129. Octavia E. Butler, Dawn (1987), Aspect and Warner, New York (1997), pp. $36-37$.

130. Butler, 'Interview with Joshunda Sanders'.

131. Butler, Dawn, pp. 132-33.

132. Butler, Dawn, pp. 36-37.

133. Octavia E. Butler, Lilith's Brood (1987-89), Grand Central Publishing, New York (2000), p. 442.

134. Butler, Dawn, pp. 159, 175, 224, 33. See also pp. 14-15, 132-33, and 
Butler, Brood, p. 289.

135. Roger Scruton, The Meaning of Conservatism, Penguin, Harmondsworth (1980), p. 68.

136. Ray Honeyford, 'Anti-Racist Rhetoric', in Frank Palmer (ed.), AntiRacism: An Assault on Education and Value, Sherwood Press, London (1986), p. 52.

137. For further critique of Scruton's and Honeyford's positions, see Hanif Kureishi, 'The Rainbow Sign', in idem, My Beautiful Laundrette and Other Writings, Faber, London (1996), pp. 94-95, and G. A. Cohen, Letter, London Review of Books, 9.21 (26 Nov. 1987), available at http://www.lrb.co.uk/v09/n21/ letters (last accessed July 2010).

138. Butler, Dawn, p. 164.

139. Butler, Dawn, pp. 19, 21-22.

140. Luckhurst, '“Horror and Beauty in Rare Combination"', pp. 31-37.

141. Butler, Dawn, pp. 40, 90.

142. Naomi Jacobs, 'Posthuman Bodies and Agency in Octavia Butler's Xenogenesis', in Raffaella Baccolini and Tom Moylan (eds), Dark Horizons: Science Fiction and the Dystopian Imagination, Routledge, New York (2003), p. 105.

143. Butler, Dawn, pp. 14-15, 6.

144. Butler, Brood, pp. 259-60. 


\section{White Rain and the Black Atlantic}

The justification for risking the annihilation of the human race was always expressed in terms of America's willingness to go to any lengths to preserve freedom [...] that readiness for heroic measures in the defense of liberty disappeared [...] when the threat was within our own borders and was concerned with the Negro's liberty.

Martin Luther King $\mathrm{Jr}^{1}$

a sufficiently fanatical Jew or Negro might dream of getting sole possession of the atomic bomb and making humanity wholly Jewish or black.

Simone de Beauvoir ${ }^{2}$

In asking how the cultural production of the black Atlantic has used the symbol of nuclear weapons to critique the supposed technological and moral superiority of the Western nations developing them, I draw upon the ideas posed by Paul Gilroy in The Black Atlantic: Modernity and Double Consciousness (1993). Seeing the capital generated by slave labour on New World plantations as a necessary component of the economic motor of modernity, Gilroy argues slavery was 'internal to western civilisation'. Yet members of the African diaspora were historically denied full citizenship of the West, with scientific racism implicated in that refusal. Central to the cultures of the black Atlantic is 'the idea of doubleness [...] often argued to be the constitutive force giving rise to black experience in the modern world'; the peoples of the black Atlantic were viewed as 'in but not necessarily of the modern, western world', relegated to a limbo of primitive stasis. For Gilroy, this ambivalence has constituted the black Atlantic as a counterculture of modernity, pointing out where its promises have gone unfulfilled for those on the wrong side of the colour line, and where the very terms of modernity's development, such as the application of rationality and scientific discovery for often irrational and racially encoded ends, must be transcended. ${ }^{3}$

This chapter explores the image of nuclear war in the context of the black Atlantic as a counterculture of modernity. It asks how racial oppression and nuclear weapons have been considered concurrently by black Atlantic thinkers, writers and performers to emphasize the structures of 
racial oppression within Western societies, and the questionable morality and desirability of the West's technological progress. Both the construction and existence of nuclear armaments and New World slavery have been justified through discourses of science and reason. As discussed in chapter 1, scientific rationales and technological developments have historically colluded in the repression of non-white imperial subjects. Nuclear weapon technology can be placed on a continuum with, in Gilroy's words, 'the racial oppression on which modernity and its antimony of rational, western progress as excessive barbarity relied'. ${ }^{4}$ It might seem inappropriate to use a black Atlantic framework to examine the moral questions asked of nuclear weapons, since one criticism made of the antinuclear movement has been its failure to include ethnic minorities until the 1980s. ${ }^{5}$ However, as the evidence below indicates, the peoples of the black Atlantic made enormous contributions to the official and unofficial face of antinuclear protest during the Cold War.

Another reason the threat of nuclear extinction resonates with the descendants of slaves might be that the racial terror endured by the peoples of the African diaspora, a terror produced and maintained by their incorporation into modernity, casts the diffused fear of the West during the Cold War in a different light. A collective memory of the experience of modernity as mass murder and race terror understands the arrival of nuclear weapons without any sense of real novelty. Writing in 1992, Mark Sinker suggests the dystopias of black SF are 'an acknowledgement that Apocalypse already happened'. ${ }^{6}$ In Literary Aftershocks: American Writers, Readers, and the Bomb (1994), Albert E. Stone writes,

Survival, though an exquisitely threatening component of twentieth-century experience, has, of course, been present in earlier ages and personal histories. Thus historical formulation can help Third World peoples, African-Americans, and others to empathize with the disintegrations in Hiroshima by analogizing them to such disasters as colonialism, slavery and the shipboard horrors of the Middle Passage, and the Civil War. ${ }^{7}$

Stone's comment could be applied to several black Atlantic texts which connect the atomic bombing of Japan to systems of racial segregation. Yet Stone's language of empathy based on comparable conditions of desperate survival seems too broad to be employed critically. It lacks the specificity of context which would allow one to think through when and why 'Third World peoples, African-Americans, and others' would exercise their emotional solidarity with the victims at Hiroshima and Nagasaki. This chapter tries to pay attention to the historical and political location of the 
cultural producers under discussion, outlining the domestic and international concerns that activated that empathy. Stone's formulation fails to countenance situations when that empathy would not be likely to be extended - by the nationalist resistance movements in Asia fighting Japanese imperialism in the 1940s, for instance. Given the boundless scope of the above quotation, when do historical occurrences of 'survival' in the face of 'disasters' exceed their capacity to be analogized to the atomic bombings? Faced with this question, Gilroy's model of the black Atlantic and germane local conditions of racism provide essential parameters to anchor the connections made with the 1945 atomic bombings in the temporal situation of the cultural producers under discussion.

American essayist and novelist Norman Mailer drew a similar analogy in 'The White Negro: Superficial Reflections on the Hipster' (1957), his diagnosis of white America's existential angst. The hipster is a figure who has chosen to live on the limits of society and behavioural norms. For Mailer, one of the formational realizations of the hipster is that 'our collective condition is to live with instant death by atomic war', a condition prefigured by the historical experiences of the African American, 'living on the margin between totalitarianism and democracy for two centuries', and unable to pass down a street 'with any real certainty that violence will not visit him on his walk'. ${ }^{8}$ Mailer's analysis wanders precariously close to mythologizing and romanticizing this existential awareness that the African American and the white hipster have come to share in nuclearjeopardized 1950s America; literary critic Thomas H. Schaub argues that Mailer's symbolic scheme deploys the kind of sexualized stereotypes of black masculinity with which racists would readily concur. ${ }^{9}$ Certainly Mailer elides crucial differences: fear of nuclear war after 1945 has been based on an always-deferred physical threat, whereas the peoples of the African diaspora have been continually subjected to actual physical violence, oppression and its attendant psychological brutalization. Further, nuclear fear has not replaced racial terror, which continues alongside it. Nonetheless, the correlation Mailer identified resounds in black Atlantic texts. In The Fire Next Time (1963), James Baldwin articulates the angst of being black in racist America, an experience that encapsulates the ontological insecurity posited by the deferred nuclear threat: 'One has been perishing here so long!' ${ }^{10}$ Writing in the Chicago Defender in September 1945, W. E. B. Du Bois's response to the atomic bomb makes a provocative association with slavery: 'We have seen [...] to our amazement and distress, a marriage between science and destruction [...] We have always thought of science as the emancipator. We see it now as the enslaver of mankind. ${ }^{11}$ Baldwin does not explicitly link African enslavement to 
enslavement by the Bomb, but overpowering terror connects them both. It seems appropriate to read Baldwin's diagnosis of racial politics in The Fire Next Time in light of the nuclear threat, given that this book was published the year after the Cuban Missile Crisis and makes reference to nuclear extinction. Baldwin lists how racial terror has been visited upon the African American:

the Negro's past, of rope, fire, torture, castration, infanticide, rape; death and humiliation; fear by day and night, fear as deep as the marrow of the bone; doubt that he was worthy of life, since everyone around him denied it; sorrow for his women, for his kinfolk, for his children, who needed his protection, and whom he could not protect. $^{12}$

Felt at its most profound, the enormity of the nuclear threat echoes Baldwin's catalogue: living with the constant possibility of an imminent, barbarous death; a threat of non-existence destabilizing one's very being; the instinct to protect loved ones mocked. In the atomic age, Baldwin recognizes that this ontological terror has been projected beyond the colour line: 'this void, this despair, this torment is felt everywhere in the West, from the streets of Stockholm to the churches of New Orleans and the sidewalks of Harlem'. ${ }^{13}$ Theorizing and writing about how black Atlantic thinkers have aligned racial and nuclear terror is a complex and precarious process, as the problematic assumptions in Mailer's essay attest, but studying this association seems too illustrative and productive not to make the connection. Both testify to our ongoing appreciation of the role of fear and atrocity in the making of the modern world. ${ }^{14}$ Baldwin offers the hope that terror need not be paralyzing, that one can break through it: 'If one is continually surviving the worst that life can bring, one eventually ceases to be controlled by a fear of what life can bring'. ${ }^{15}$ This commitment to enduring nuclear and racial terror long enough to effect the social transformations necessary to eliminate them both is a touchstone for hope throughout many of the texts discussed here.

The first section of this chapter examines representations of nuclear weapons which set out the case that their use is informed by hierarchies of racial difference. This includes representations that understand the USA's use of atomic and nuclear bombs in the Pacific as the exportation of domestic racial attitudes overseas. This leads into a discussion of texts that pose the question, if the technological zenith of the Western world is the construction of weapons capable of extinguishing human life from the planet, how can that trajectory of progress, compromised already by complicity with racial oppression, continue to be valid? If the 'onward 
march of Western Reason'16 is overshadowed by nuclear extinction, where does that leave the proclamations of racial superiority predicated on the desirability of modernity's prizes?

This chapter then shifts to Langston Hughes and his stories featuring the character Jesse B. Semple (Simple). Simple is a resident of Harlem, originally from Virginia, and his inimitable commentary on American society and Harlem life exasperates his wife, Joyce, and his friend, Boyd, the stories' narrator. The stories under examination stretch from 1945 to the 1960s, and they include the anxiety surrounding the Berlin and Cuba crises. Hughes' representations of atomic fallout shelters illuminate the practical and moral limitations of America's Civil Defense measures, and in doing so, make apparent the inequalities characterizing mid-twentiethcentury American society. As an indication of the stories' frankness about American inequalities, Ken Cooper states Hughes was called before the House Committee on Un-American Activities in 1953 and 'taken to task for his Simple columns in the Chicago Defender' ${ }^{17}$

At this point, I reflect upon Derek Walcott's essay 'The Muse of History' (1974), which distances black Atlantic communities from nuclear modernity. I question whether this reinforces the ahistorical and antimodern status of the African diaspora - whether seeing the contemporary political moment in terms of myth entrenches the separateness of peoples. The Black Atlantic asserts that the cultural production of the African diaspora demands that modernity fulfil its promises of emancipation and civic coexistence in pursuit of 'the best possible forms of social and political existence'. ${ }^{18}$ This is not a rejection of modernity but a renewed commitment to the equality and human possibility modernity represents. Ishmael Reed's novel Mumbo Jumbo (1972) makes a case - through literary myth-making - for saving Western civilization from nuclear cataclysm by reconciling that civilization with the black Atlantic values it has historically abjected.

These issues echo through black Atlantic debates into the Cold War and the space race. How credible is it that the strides in space exploration made by NASA are 'giant leaps for mankind' when space-travel technology was developed for military advantage? While some black Atlantic texts are sceptical that the population of the world will benefit from an increasing American grip on outer space, Langston Hughes imagines a future in which the racism corrupting US society is transcended in an atomic-powered space-age vision. This chapter concludes by offering the voices of those like Hughes, such as Martin Luther King Jr, who realize that confronting contemporary racial injustice on an international scale must be connected to nuclear disarmament programmes. 


\section{White Rain}

The idea that America's use of nuclear weapons reflected contemporary racial hierarchies could be seen in black Atlantic texts as soon as news of Hiroshima and Nagasaki began circulating around the world. ${ }^{19}$ In his longrunning series of syndicated short stories featuring the character Simple, Langston Hughes 'was one of the first to voice the widely shared attitude of blacks and some whites that it was no coincidence the Bomb was first used against yellow-skinned Japanese, not white Germans'. ${ }^{20}$ 'Simple and the Atomic Bomb', first published in 18 August 1945, countered the euphoric mood of Allied populations that the atomic destruction of Japanese cities was a triumphant conclusion to war in the Pacific. Instead, this may be another example of the barbarity non-whites have been subjected to throughout modernity. ${ }^{21}$ Hughes places the atomic bomb decisively in white hands by writing Simple's declaration that white people 'don't want no Negroes nowhere near no bomb'. ${ }^{22}$ The story 'Bones, Bombs, Chicken Necks' (1961) connects domestic racism to the 1954 hydrogen bomb tests at the Marshall Islands. Referring to the radioactive effects of the nuclear explosion's fallout, Simple believes the Marshall Islanders 'will never have no more hair on their heads, and them atomized Japanese fishermens will have no more children'. ${ }^{23}$ Simple's last remark refers to the crew of the Japanese fishing vessel Lucky Dragon, caught within the irradiated area of the Pacific. ${ }^{24}$ This act of racial chauvinism in the Pacific is linked to the African-American experience of subordination: 'American white folks [...] gotten so accustomed to mistreating Negroes at home in the past that it is hard for them to care about what colored folks in Asia think. ${ }^{25}$ In 'Not Colored' (1965), Simple recalls recovering a lost ball from a neighbour's lawn as a child:

that grown white man hauled off and kicked me in my shins $[\ldots]$ Wow! You know how bad it hurts to get kicked on your shins? It hurted me so bad I could not cry and I could not run [...] He said, 'I guess that will teach you little black bastards to get on my grass. ${ }^{26}$

Simple ends his recollection with, 'Which is one reason why them Japanese do not want no parts of Americans in their hearts. They remember Hiroshima.' Simple sees the localized brutality done to his person as existing on a continuum with the atomic bombing of Hiroshima. Both can be attributed to an image of non-whites as less human and their bodies as legitimately violated, which is expressed as violence against black children in the South and the use of atomic bombs against the Japanese. Simple asks, 'Don't you see no connection between atom-bomb-dropping in Japan 
and shin-kicking in Virginia?' The narrator replies he cannot. Simple retorts, 'Then you are not colored' ${ }^{27}$ From a racially subordinate position, it is apparently impossible not to perceive how America's actions domestically and abroad share the refusal to value non-white lives equally with whites. Malcolm X expressed the same sentiment: 'Can the white man be so naïve as to think the clear import of [the atomic bombings] ever will be lost upon the non-white two-thirds of the earth's population?'28

Olive Senior engages with this in the poem 'rain' (1985), in which the motif of rainfall stands for different aspects of violence in neocolonial struggles such as the Vietnam War. Senior plays with the popular memory of the black rain that fell on Hiroshima after the dropping of the atomic bomb: ${ }^{29}$

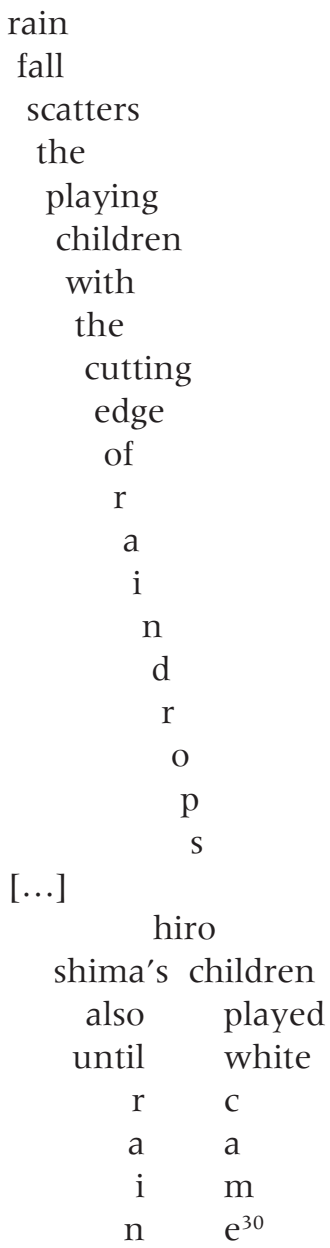


The black rain carrying radioactive fallout is transformed into the "white rain' of the bombs themselves. This shift suggests that assumptions of white racial superiority underlined the decision to drop atomic bombs on Hiroshima. Senior's symbolism also coheres with the convention of using children to connote the range and awfulness of nuclear weapons. As Edward Brunner's Cold War Poetry (2001) notes in a variety of nuclearthemed poems from America in the 1950s, the status of children 'Powerless, unarmed, appealing to adults for protection' - encapsulated the overall population's defencelessness: 'the child is the civilian par excellence'. ${ }^{31}$ In the Winter 1950 edition of the Poetry Society of America's magazine Voices (an 'All Negro' issue edited by Langston Hughes), Leo Richards's poem 'Where Are Your Worshippers' asks a priest to account for the emptiness of an 'abandoned cathedral' amidst a parade of bloody, surreal imagery that personifies war as living and breathing. Brunner comments that when the poetic voice shifts its addressed subject from the priest to 'Hiroshima - / Where have your children gone?' a general lament for the destruction of a civilian population is specified as the obliteration of the next generation. ${ }^{32}$ One could argue 'Where Are Your Worshippers' hails the eradication of Hiroshima's future citizens as a symbol of the USA's desire to exterminate the Japanese, but I think it is most accurate to understand Richards's concentration on Hiroshima's children as part of the repeated citation of youth as the first rank of human posterity, the entirety of which was jeopardized by nuclear weapons. ${ }^{33}$

Donald Robinson's article 'If H-Bombs Fall...' in the Saturday Evening Post (25 May 1957) records how the African-American community of Mobile, Alabama was fearful such weapons would be used to prevent the desegregation of schools:

During a scheduled civil-defense exercise a downtown section of the city was to be evacuated. But before the exercise began, a rumor started in the Negro districts that an atomic bomb was really going to be dropped. 'They're going to kill all us Negroes so they don't have to go through with school desegregation,' the rumor had it. A large number of Negroes accepted this as truth. They took to the roads, carrying their most precious belongings with them. ${ }^{34}$

Robinson's report testifies to a lived sense of anxiety that atomic weapons could be directed against African Americans and the demand for equal access to state facilities. Writing to the Atomic Energy Commission, Clarence Mitchell Jr, the labour secretary of the National Association for the Advancement of Colored People (NAACP), stated that many 'colored people have regarded the Atom Bomb as a new device for maintaining 
white supremacy'. ${ }^{35}$ In Dr. Strangelove's America: Society and Culture in the Atomic Age (1997), Margot A. Henrikson observes that in this context the atomic bomb could represent both 'a genocidal threat against blacks in the cold war years' and a 'powerful metaphor' for the explosive repercussions of racial oppression. ${ }^{36}$ Henrikson points to the poem 'Harlem', from the collection Montage of a Dream Deferred (1951), in which Langston Hughes uses an explosion to symbolize the destructive diversion of African-American energies denied full access to the upward mobility promised by the American Dream. Its oft-quoted opening line, 'What happens to a dream deferred', asks a question answered by the italicized final line, 'does it explode?'37 In Hughes' poem 'Lunch in a Jim Crow Car' (1959), the context of the atomic era has become apparent:

Get out the lunch-box of your dreams.

Bite into the sandwich of your heart,

And ride the Jim Crow car until it screams

Then - like an atom bomb - it bursts apart. ${ }^{38}$

Like 'Harlem', one is confronted by an immense anger at the racial oppression leaving African Americans unable to realize their 'dreams'. Biting into 'the sandwich of your heart' suggests desire denied and consuming itself without an outlet for attainment. Placing this within the Jim Crow car stresses it is the racism present within 1950s America, symbolized in segregated railroad carriages, that forces African Americans to cannibalize their hopes and goals. The repression of desire will not endure indefinitely, and the precariousness of this process is signified by the screaming of the Jim Crow car under the pressure of so many dreams deferred. This tension that cannot be contained can be seen in the number of syllables in each line creeping up from eight in the first line to ten in the last. In that final line, the violent repercussions of the USA's policy of racial oppression find an appropriate simile in the detonation of an atomic weapon. This is reproduced in the Simple story 'Radioactive Red Caps' (1961): the explosive vengeance of blacks is linked with the image of nuclear war to argue that white America will bring destruction upon itself. Simple imagines an atomic bomb in African-American hands: 'Just think what would happen to Mississippi. Wow!'39 At the end of John A. Williams's novel Captain Blackman (1972), a fictionalized history of black servicemen in the American army, the country's nuclear defence system is seized in a coup by black soldiers passing as whites; possession of nuclear weapons grants the leverage to redress centuries of racism, and not just within the United States, but throughout Europe's colonies. Similarly, Baldwin's The Fire Next Time includes the receding imperial powers in its warning that the white West will be undone by its inability to correct racial oppression and make 
good the destructiveness of nuclear weapons. The book's title refers to the flood of Genesis as 're-created from the Bible in song by a slave [...] God gave Noah the rainbow sign, No more water, the fire next time!"40 Although this fire refers to the anger of oppressed blacks against white rule, its imagery draws upon fears of nuclear fire from the skies. ${ }^{41}$ The historical context of The Fire Next Time, emerging in the immediate wake of the Cuban Missile Crisis, provides an imperative tone; for Baldwin, humankind's nuclear jeopardy, so evident during October 1962, signifies the unavoidability of violence within the project of modernity. This is politically charged because the advances of civilization have been celebrated as the progressiveness of white Europeans and their descendants, ${ }^{42}$ or, in Baldwin's words, this 'is the best that God (the white God) can $\mathrm{do}^{\prime} .{ }^{43}$ With the arrival of possible nuclear extinction, modernity's achievements no longer seem desirable:

the threat of universal extinction hanging over all the world today [...] changes, totally and for ever, the nature of reality and brings into devastating question the true meaning of man's history. We human beings now have the power to exterminate ourselves; this seems to be the entire sum of our achievement. ${ }^{44}$

Baldwin asks readers to see beyond a false history of modernity, characterized by progress and hope, through to the 'true meaning' of the history of the modern world: the escalation of racial genocide underpinned by science, until extinction is now available to all humanity.

A version of Baldwin's position is present in the poem 'Mont Blanc' (1987), written by the Caribbean critic and poet Edward Kamau Brathwaite. Its title, referring to the highest mountain in the Alps, alludes to Percy Bysshe Shelley's 1816 poem of the same appellation. Shelley's poem connects the sight of Mont Blanc to an unknowable force that lies behind the workings of the natural world: 'Power dwells apart in its tranquillity, / Remote, serene, and inaccessible'. This 'Power' is embodied in the inexorable 'creep' of the glaciers, rolling over the mountainside and erasing the dwellings belonging to 'insects, beasts', and the 'race / Of man'. This omnipotent force drives and organizes the universe, 'a law' stretching to 'the infinite dome / Of heaven', and it lies behind human cognition, too, although it might not always be recognized as such: it is the 'secret Strength of things / Which governs thought'. In Shelley's 'Mont Blanc', this 'Power' can be a moral and creative resource when sensitive human minds (such as that of the poet) channel the mountain's magnitude and its impression on themselves into a wider sensibility of the relationship between humans and nature: 
Thou hast a voice, great Mountain, to repeal

Large codes of fraud and woe not understood

By all, but which the wise, and great, and good

Interpret, or make felt, or deeply feel! ${ }^{45}$

Brathwaite's poem reinterprets the mountain as a force of creativity by stressing the destructivity of the inventiveness it represents; it seems to argue that the rise of Western civilization depended on keeping Africa enslaved and underdeveloped while Europe's empires and their successors harvested the fruit of technological ingenuity. The opposition between Europe and Africa is first honed by Brathwaite's address to Mont Blanc as 'glacier of god / chads opposite' ${ }^{46}$ His poem heralds the mountain as a Christian monument and juxtaposes it against the chads (staked out land; Chad is also an African nation) it faces, which we later learn to be Africa. Symbolizing Europe as a modern Christian continent in Brathwaite's poem, the 'wealth' and 'power' of Mont Blanc is emphasized and Europe's technological and economic modernity is bound up in its representation: 'industry was envisioned here in the indomitable glitter'. The mountain signifies the power and creativity of the West in staggering and terrifying ways:

volt crackle and electricity it has invented

buchenwald nagasaki and napalm

it is the frozen first atomic bomb.

Brathwaite references two of the USA's most controversial twentiethcentury weapons, atomic bombs and napalm, and by including American technology in his poetic critique, the United States is projected as an extension of European civilization. Taking our cue from a translation of the poem's title into English, suggesting a towering edifice of whiteness, Brathwaite indicates how the racial code signified by the colour white has been influential in Europe's construction of its own image and the USA's selfperception of nationhood. Certainly the choice of atrocities cited in these lines indicate that it is the people deemed to fall outside the pale of whiteness who are most victimized by the inventiveness of Europe and the USA (this interpretation assumes 'napalm' is intended to trigger memories of its use in the Vietnam War). To identify Mont Blanc as the frozen first atomic bomb' implies that the trajectory of Western civilization inevitably works towards the technology of unimaginable destruction which has given shape to the mountain's representation in the poem.

A change of scene and tone is heralded by the lines 'as it [Europe] rises / chad sinks' and a catalogue of images of aridity follow. The date of publi- 
cation for 'Mont Blanc' suggests that the Ethiopian famine of the mid1980s constitutes Brathwaite's frame of reference, as atomic imagery infiltrates the description of famine victims:

skin mouldered to ash

holocaust of dome

heads propped up on sticks of skeletones.

The enjambment between the second and third lines reproduced above switches the image of the mushroom cloud ('holocaust of dome') into the shape of a child whose physical frame is malformed because of starvation ('dome / heads propped up on sticks of skeletones'). Brathwaite's ire is directed towards the journalists who are 'closing in [...] like buzzards' on this spectacle of suffering, the 'flim [sic] crew cameras' emphasizing how dehumanized these famine victims are through a visual language of 'scarecrow' herdsmen, naked children and breast-feeding mothers. Once more this takes place 'in the shadow' of Mont Blanc and the 'snow and ici/cle', and the division of 'icicle' into component parts has the effect of doubling its meaning, as the French 'ici/cle' translates into English as 'here/key'. This reinforces Mont Blanc as the centre of meaning in the poem, the code from which the whole can be navigated. The poem's final lines suggest that African underdevelopment and European prominence will escalate, and the ascendancy of modernity towards the horizon bears uncomfortable visual similarity to the mushroom cloud:

\author{
this eye \\ less rise \\ ing gas \\ face mountain. ${ }^{47}$
}

Again, in breaking language up, Brathwaite multiplies his meanings. Phonetically, he offers a morally blind structure whose rock face is ascending like a gaseous substance: these lines could be read as 'this eyeless rising gas-face mountain'. One can also read each line as holding a discrete meaning, where 'this eye' refers to the collective eye of the cameramen filming the Ethiopian famine, who present the famine's victims as the opposite of well-fed Western television audiences. The voice of the poem addresses this (implicitly white European or American) 'eye', prohibiting its ascent with the words 'less rise' and demanding that the 'eye' confront the poem's master symbol of modernity: 'face mountain'. By the close of 'Mont Blanc', Brathwaite has observed the atrocities perpetuated by Western civilization (during the Holocaust, World War Two and the 
Vietnam War) and the human suffering it observes with pity but insufficient material intervention (the Ethiopian famine), and the proliferation of meaning in his poetic language suggests he is unsure whether the edifice of modernity will continue to expand, disappear into a rising body of cloud or confront its own privilege.

During an argument with his wife Joyce, the character Simple also locates nuclear weapons in a global perspective; Simple has been 'Eating bones in the window' and Joyce chastises him because it 'just isn't done in high society'. Simple's defence is that his country's behaviour is worse than his table manners: 'Atom bombs is low-rating the tone of the whole world. When I gnaw my bone [...] I am not hurting a human soul.' He outmanoeuvres her citation of white American codes of propriety by referencing American nuclear tests in the Pacific: 'It looks like to me it would be better to gnaw a bone than to singe them Marshall Islanders all up [...] I think white folks would do better to set [sic] in their front windows and gnaw bones myself'. ${ }^{48}$ The literal and metaphorical fallout from the country's nuclear tests is not a convincing example of mannered behaviour for this American.

\section{Jim Crow Shelters}

The atomic bomb shelter and who has access to it is a significant component of the nuclear imagination in the Simple stories. Hughes wrote alongside the preparedness narratives that followed the Soviet Union's testing of an atomic bomb in 1949. The Federal Civil Defense Administration (FCDA) was established in 1950 to educate the public through films, pamphlets and community preparedness programmes about survival in a nuclear war. Surveying the pamphlets produced by the FCDA and its successor, the Office of Civil and Defense Mobilization, Sharp notes,

The imagery showed once again the racial imagination of civil defense officials about who would populate the nuclear frontier: with large numbers of blacks and poor people likely to be wiped out in the initial blast, officials focused their planning and propaganda on the politically expedient imagery of the white suburban family. ${ }^{49}$

Hughes repeatedly suggests the racial recipe within shelters will be policed, with the injustice characterizing American life determining who will be allowed to survive. In 'Radioactive Red Caps', Simple is certain 'If I was in Mississippi, I would be Jim Crowed out of bomb shelters'. The narrator Boyd naively protests Civil Defense 'will be for everybody', but Simple's experience teaches him that access to shelters will be colour-coded in the 
South through the institutional racism that masks itself in the rhetoric of impartiality: 'Down there they will have some kind of voting test, else loyalty test, in which they will find some way of flunking Negroes out. ${ }^{50}$

In 'Atomic Dream' (1965), Hughes stretches the inhumanity of segregation to a grotesque extreme. Boyd asks Simple, 'Do you mean to tell me the white South would be so inhumane as to build public bomb shelters with signs up WHITE ONLY, and none for Negroes? What kind of people live in Dixie?'51 Readers are invited to consider how this representation might be uncomfortably close to the systematic destruction of black lives in the American South. Simple hypothesizes that African Americans would be allowed into bomb shelters to serve whites: 'Just suppose all the Negroes down South got atomized [...] who would serve the white folks' tables, nurse their children, Red Cap their bags, and make up their Pullman berths?'52 Any African Americans who survived nuclear war in the South would be expected to maintain their subservient roles. They would only be permitted inside 'a little old Jim Crow shelter in Uncle Tommy's back yard meant just for handkerchief heads', ${ }^{53}$ 'Uncle Tom' being a colloquial term for a 'spineless, sycophantic Negro'.$^{54}$ The African Americans fighting in the civil rights movement against segregation would have to protest to find shelter: 'The Freedom Riders would have to ride awhile to get in out of the fallout.'55 Of 'Radioactive Red Caps', Sharp comments, 'Hughes showed that African Americans were not fooled by the FCDA's reassurances' and on the occasions when African-American newspapers reported on America's civil defence preparations it was with a critical tone. ${ }^{56}$

It seems a bomb shelter 'full of Negroes' 57 could only be possible in Simple's 'Atomic Dream'. The bomb shelter in Simple's dream acts as a microcosm of African-American society ('just as if they was on Lenox Avenue', a famous Harlem street), and it is another example of the paralleling of nuclear fear and racial terror discussed above. Lena Horne sings the blues down in the shelter, 'In the wee small hours when the one you love is gone. ${ }^{58}$ The development of the blues has been interpreted as an articulation of African-American deprivation, and the attendant loss and longing for separated or dead family members and loved ones. ${ }^{59}$ This seems applicable to a fallout shelter of survivors negotiating the memory of those dead and dying outside. Hughes thus gestures towards how the experience of nuclear fear is related to the racial terror inflicted upon black Atlantic populations, and how the mechanisms for black physical and mental survival might be translated and revalued in a world where nuclear extinction is possible. For Hughes, African America's constant exposure to the terror of imminent death since plantation slavery has established conditions of courage readily adaptable to the extended overhanging threat of 
nuclear war. Simple's assertion he will not be killed by an atomic bomb is a product of this: 'If Negroes can survive white folks in Mississippi [...] we can survive anything.' These resources of endurance prevent Simple from being tortured by anguish over nuclear war, providing him with the hope that after atomic destruction the possibility of social change would be increased: 'Negroes are very hard to annihilate. I am a Negro - so I figure I would live to radiate and, believe me, once charged, I will take charge. ${ }^{60}$

Simple's atomic dream comes to an abrupt end. Despite the supposed security of the shelter, the bomb falls - 'BAM!' - and Simple is 'blowed [...] down. And I woke up screaming! My dream had turned into a nightmare. ${ }^{\prime 61}$ The dream that bomb shelters and other Civil Defense measures offer any sort of protection in a nuclear attack is thoroughly scorned in the Simple stories. Instead, they are a new form of familiar exploitation. In the story ‘Bomb Shelters' (1965), Simple broods, 'Our landlord last week came talking to me about he was going to have to raise our rent in order to build us a bomb shelter in the back yard.' Simple is sceptical that protection against nuclear war is possible in a crowded urban area: 'how could landlords build enough shelters for every roomer?' It is another example of the financial 'trickeration'62 that handicaps African America and the bomb scare occasions another opportunity for the uneven economic status quo to be reinforced. Simple sees through the 'mask of civil defence', ${ }^{63}$ since even if the shelters were effective, the surrounding infrastructure and ecology would be irradiated and irrecoverable. Simple defines this in personal terms, lamenting that 'when you come out, your favourite bar would be blowed to hell and gone, your best barbershop would be missing, and your pastor dead from passive resistance'.${ }^{64}$ The most persuasive reason not to build a bomb shelter in the Simple stories is the inhumanity of choosing and enforcing who survives. Simple imagines the dilemma he and Joyce would face when the 'atom sirens [start] sounding' and they are confronted with the family on the ground floor who also want protection. Simple envisages a series of arguments over which two people are allowed inside, before 'the all-clear signal' sounds and Joyce expresses her relief to Simple:

let's tear that shelter down tomorrow. I could not go in there and leave them children and Grandma outside. Neither could I leave you outside, baby, Jess darling, my life! [...] If the bomb does come, let's just all die neighborly. ${ }^{65}$

This refusal to participate in the USA's Civil Defense programme suggests that perhaps bomb shelters are another way of stratifying society, with survival only available to those who can afford it. In March 1962, Bertrand 
Russell called civil defence 'a matter of calculated fraud for profit'. ${ }^{66}$ The official doctrine of individual survival in a nuclear attack through private shelters was at its most intense in the middle of 1961, in response to the Berlin Crisis ${ }^{67}$ On 25 July 1961, President Kennedy addressed the nation on television and 'urged the country to prepare for thermonuclear war by building family fallout shelters' ${ }^{68}$ After this speech, twenty-two million copies of the Department of Defense pamphlet The Family Fallout Shelter were distributed. The notion of private family shelters implies in its economic dimension that the citizens who survive into the future will be the most affluent Americans (implicitly privileging the white sections of society): 'individual shelters were well beyond the financial means of many Americans'. ${ }^{69}$ Further, Civil Defense programmes were not directed towards the demographic group that Hughes' characters represent, and Sharp's observations confirm Joyce and Simple's criticisms: 'Pamphlets like Six Steps to Survival encouraged white suburban families to hunker down in their fallout shelters [...] People in the urban core were advised to run, but their prospects for survival in these publications seemed bleak at best. ${ }^{170}$ Hughes contrasts the American state's prescription to build private shelters against Joyce's wilful rejection of the shelter and the dubious Civil Defense programme it symbolizes. Apart from its practical limitations, readers are encouraged to look beyond the shelter and the idea of individual safety towards a collective fate. As a human species, we are all jeopardized by the threat of nuclear war, and unified as a consequence. In World War Three, we will 'all die neighborly', as Joyce puts it. Only by accepting the interdependence of our lives and futures can this be avoided.

\section{Rejecting Nuclear Modernity}

The assumption of white racial authority in the modern era reciprocated an image of the African diaspora as representatives of humanity's primordial past, eternally excluded from modernity. For influential European philosophers, the continents of Europe and Africa and their respective populations might be geographically close but they did not exist in the same historical time. Europe was history's leading edge, while Africa had yet to start its historical journey. Several European thinkers expressed their continent's entitlement to see modernity as its own. ${ }^{71}$ We saw above how black Atlantic critiques adopted an antagonistic stance towards a nucleararmed modernity. The precariousness of this position is that it can reproduce the ahistorical exteriority of the African diaspora and certain black Atlantic voices perhaps accept that externality is an acceptable cost to escape modernity's apocalyptic direction. For instance, Derek Walcott 
writes of a space outside modernity, secure from its exhibitions of danger. In 'The Muse of History', Walcott uses nuclear destruction to mock the story modernity tells itself about 'progress':

It should matter nothing to the New World if the Old is again determined to blow itself up, for an obsession with progress is not within the psyche of the recently enslaved. That is the bitter secret of the apple. The vision of progress is the rational madness of history. ${ }^{72}$

The referent of the term 'the New World' is not always clear in this essay; it sometimes means the inhabitants of the Americas, white or black, in the process of unburdening themselves from the disfiguring legacies of the colonial period. However, its usage here, in relation to the recently enslaved', indicates specific reference to the African diaspora. Walcott argues for disassociating the cultural production of the New World from the foundational narratives of the Old World, what might be European modernity (the 'vision of progress'). As a corollary to this disassociation, the possibility of extinction becomes extraneous. Despite imagining the plausibility of World War Three, neither modernity nor its nuclear threat features in Walcott's symbolic solution to the disfiguring historic scars of the colonial era's race terror: a prelapsarian 'Adam' figure. Walcott observes that the Old World's tendencies towards global catastrophe should not matter to the New World (the term 'New World' is straining at its semantic seams at this point).

In a slightly different vein, novelist Ishmael Reed relocates the nuclear danger within a struggle between metaphysical forces in his novel Mumbo Jumbo (1972). The novel traces a pattern of conflict going back to ancient Egypt. Two princes, the brothers Osiris and Set, represent different modes of existence. Osiris prohibited cannibalism and promoted sorcery, agriculture and agricultural celebrations such as music, singing and dancing. Set is arrogant, egotistical, jealous, believes in invading foreign countries and likes giving orders and 'discipline'. He has 'shut nature out of himself'. ${ }^{73}$ Mumbo Jumbo interprets human history through the lens of these oppositional characters: various societies, institutions and individuals are hailed as Osiris's and Set's symbolic heirs, from Julian the Apostate Emperor (defending the Osirian tradition) to John Milton and Sigmund Freud (embodying the values of Set). Set established the Atonist path, whose devotees sneer at celebration and valorize asceticism, penance, and the working day. The last Atonist tenet associates them with the sun, the natural 'time clock' of the working day and other 'negative aspects' of light; ${ }^{74}$ repeatedly described in terms of the Sun's energy and light, nuclear destruction is brought into the world by villainous Atonists. Having 
outlawed the Osirians and desiring to 'fasten his hold on the populace', Set commands a bokor (a deceitful sorcerer) to copy one of his brother's miracles. But the bokor is 'insufficiently trained [and] raised the temperature of Egypt to over 50,000 degrees resulting in something resembling an A-bomb explosion'. The Atonists are evidently unable to wield nature's power safely. Later in history, Moses appropriates Osiris's magic as Set manipulates Moses to restore the Atonist cult to Egypt. To disperse a disorderly crowd, Moses unleashes an even bigger explosion, sending up 'a huge mushroom cloud'. The next day 'dead and dying' fauna wash up on the shores of the Nile. Mumbo Jumbo posits that the Atonist path is entrenched in white Western Christian culture (Christ is labelled a bokor for raising the dead) and nuclear war will be one future consequence. Primarily set in the 1920s, the black male character Berbelang makes the prognosis, 'Western man['s] bokorism will improve. Soon he will be able to annihilate 1000000s by pushing a button. I do not believe that a Yellow or Black hand will push this button' ${ }^{75}$ These three examples constitute the novel's genealogy of Atonist misuse of the energy contained in the universe, and its future manifestation is racially encoded as the white West. Critic Ken Cooper observes atomic bombs are not "the "subject" of the novel but [...] shorthand for the violence implicit in Western Civilization's religious and cultural "crusades." "76 Berbelang tells his white companion Thor, 'We must purge the bokor from you' with an infusion of Jes Grew, a contagious spirit of life manifesting itself in dancing and raucousness. Mumbo Jumbo implies that the slave trade brought the infection to the USA because black Africans are 'Jes Grew carriers' ${ }^{77}$ Cooper argues this scene between Berbelang and Thor is a radical one because it reverses the ethnocentric assumptions of antiproliferation ('which intimates that Non-Western societies are too unstable and emotional to possess nuclear weapons') and judges the Western nuclear powers from the position of 'an older, wiser culture'.$^{78}$ What this scene reinforces, though, is the considerable distance between Western and non-Western practices of knowing the world, and while Cooper is correct to read Berbelang's criticisms as laying claim to the authority of ancientness, this can be an unstable argumentative route. Berbelang justifies his commentary with reference to older Chinese and African technology, technology he says knew 'when to stop' to avoid the scale of Western science. This picture easily slides into a scenario of (willing) non-white arrested development, lodged in the past, while white technology lays claim to the future.

Mumbo Jumbo expresses the desire to reunite the separate worlds in the novel. It enforces a colour line of responsibility and destructiveness (unsurprising, since it was published during the era of Black Power) but seeks to 
cure one historical force by uniting it with the other. I suggest reading Reed's literary mythology as a set of parables on authoritarianism and power, whose characters have direct referents in twentieth-century history - they are not merely metaphysical archetypes. Additionally, rather than myth setting the terms for eternal incompatibility, these parables argue for the reconciliation of contradictory forces to redirect modernity in the present.

\section{Beyond Colour: The Final Frontier}

In the Bulletin of Atomic Scientists (June 1957), Richard S. Leghorn warned 'perhaps even space platforms [for the launching of nuclear rockets] will be imminent'. ${ }^{79}$ In October 1957, the launching of Sputnik 1 catalyzed public awareness of what Leghorn had foreseen: 'The Soviet rocket that launched the first human-made object into space also brought home to America the threat that [a] rocket that could put a satellite in orbit could just as well send a thermonuclear warhead on a ballistic trajectory to the United States. ${ }^{80}$ One response to the Sputnik launch was Project Orion, controlled by the United States Air Force, which envisaged constructing a spaceship propelled by nuclear bombs. Established in 1958, the atomic scientists involved in Project Orion felt partly responsible for the military application of nuclear physics at the end of World War Two, and hoped that the 'bombs that killed and maimed at Hiroshima and Nagasaki might open space up to mankind'. Conversely, the USAF thought this 'interplanetary ship' could be used to transport troops, and to blast the biggest hydrogen bomb possible into space, to hang over the Soviet Union as a 'doomsday device'. President Kennedy was horrified at the prospect of a 'giant nuclear weapons race in space', and the 1963 Test Ban Treaty signed by the USSR and the USA prohibited the use of nuclear weapons in outer space. ${ }^{81}$ The exploration of the cosmos and the nuclear arms race were closely intertwined before and since Sputnik and Project Orion. That the language of exploration was central to imperial domination was discussed in chapters 2 and 3, and exemplifying the limitless desire to appropriate territory, the nineteenth-century British imperialist Cecil Rhodes proclaimed, 'I would annex the planets if I could'..$^{82}$ At an 'Anti-Nuke Rally' at Grace Cathedral in San Francisco in 1982, writer Alice Walker stressed 'the enormity of the white man's crimes against humanity'; she cursed the acquisitive, destructive tendencies of white men. For Walker, they must not be allowed to dominate, exploit and despoil [...] the rest of the universe, which is their clear and oft-stated intention; leaving their arrogance and litter not just on the moon, but on everything else they can 
reach' ${ }^{83}$ In the short story 'The Moon' (1965), Langston Hughes sees domination, exploitation and ecological disaster as consequences of America's expansion into the cosmos. Once more Simple contrasts the pretence of white racial superiority against the evidence of its ethically bankrupt actions:

'White is right', said Simple, 'so I have always heard. But I never did believe it. White folks do so much wrong! Not only do they mistreat me, but they mistreat themselves. Right now, all they got their minds on is shooting off rockets and sending up atom bombs and poisoning the air and fighting wars and Jim Crowing the universe.'

Simple's criticism of how white America sees the space race as part of its project against communism is dismissed by Boyd: 'You are a great one for fantasy [...] Maybe stemming from your movie-going days' ${ }^{84}$ But that is exactly one cultural location where the need to conquer space for national security circulated, before the heightened tensions of the Sputnik era. The film Destination Moon (1950), directed by Irving Pichel, combined atomic energy and the space race to fight the Cold War. Powered by an 'atomicenergy engine', a consortium of US businessmen builds a rocket to reach the Moon. Their motivation is the creation of a strategic missile base for American atomic power: 'the first country that can use the Moon for the launching of missiles will control the Earth'. William Cameron Menzies's Invaders from Mars (1953) also suggested that interplanetary stations [...] equipped with atomic power' would ensure absolute victory for the superpower possessing them: 'if any nation dared attack us, just by pushing a few buttons we could wipe them out in a few minutes'. The Simple stories are in dialogue with this project to establish US global hegemony by bringing atomic energy and weapons into space and Hughes warns that this would not mean freedom but the expansion of American racial injustice into every corner of the globe and beyond. This possible future is parodied by Simple's imaginative segregation of the Moon: 'if one of them white Southerners gets to the moon first, COLORED NOT ADMITTED signs will go up'. This is why there have been 'no Negro astronaughts nowhere in space yet'. If US expansion and virulent anticommunism continues to dominate scientific research, the Moon may become a reflection of the racism in the American South: 'I wonder if them Southerners will take police dogs to the moon?' ${ }^{85}$ Contemplating nuclear fission's potential to be a new energy source transforming humankind for the better, novelist and journalist George S. Schuyler wrote mockingly in an August 1945 newspaper article that 'Negro insurance executives from Durham and Atlanta will be vacationing on the moon or Mars, albeit in the Negro section. ${ }^{\prime 86}$ 
Hughes offers an alternative to the atomic-powered and atomicdefended exportation of American racism into the cosmos. In the short story 'High Bed' (1961), Simple demands that modernity fulfil its promise of technological emancipation in a dream of a future where atomic power enables personal travel. Simple imagines an 'Age of the Air when rocket planes get to be common', but he 'would not have no old-time jet-propelled plane either. My plane would run on atom power' ${ }^{87}$ From this technology a new global community would be established, based on Simple's habits of alcohol consumption and socializing, although this is a gendered space, where it seems only men will be free to participate in the new global community of drinking. Atomic power will free men from quotidian domestic spheres, allowing them to rocket around the world, where the women of different cultures will receive them with hospitality. The transgression of racial and national limits reinforces the assumptions of gender that locate activity as male and passivity as female.

In this transnational era, the distance between peoples and cultures would be erased. The scars of America's use of atomic weapons in 1945 will be healed and Americans will be invited to 'fly to Nagasaki and drink saki'. Definitions of race are exploded in this new space that is at once civic and global:

such another scrambling of races as there is going to be when they gets that rocket plane perfected! Why, when a man can shoot from Athens, Georgia, to Athens, Greece, in less than an hour, you know there is going to be intermarriage. I am liable to marry a Greek myself [...] I would not be prejudiced toward color. ${ }^{88}$

Hughes' projection is avowedly utopian and respects no obstacles to communication based on nation or the perception of race. It seems important that he uses an SF vision in this story. Walter Mosley contends the 'genre speaks most clearly to those who are dissatisfied with the way things are [and] this may explain the appeal that science fiction holds for a great many African-Americans' ${ }^{89}$ In other words, Hughes speculates on the future precisely because he seeks an alternative to the present, because he seeks to transcend race thinking along with the forces of gravity: 'I would rock so far away from this color line in the U.S.A., till it wouldn't be funny. I might even build me a garage on Mars and a mansion on Venus. ${ }^{90}$ This image of what-has-yet-to-be-achieved with nuclear power indicts the military uses it has been applied to so far, compelling a radical rethinking of how best to utilize and fulfil the emancipatory promise of this new technology. Hughes offers a vision that transcends national difference and the racism mutilating America in the Simple stories. 


\section{Antinuclear Politics and the Transcendence of Race}

'High Bed' offers the promise of hope, albeit far-fetched, and similar hopes for the future have been reproduced by figures such as Alice Walker, James Baldwin and Martin Luther King, Jr. What unites them is the assertion that successful antinuclear politics must comprehend the divisiveness of thinking in terms of racial difference, and that campaigns against racism should be linked to calls for disarmament if they are to be meaningful movements for equality and human rights.

At the aforementioned 1982 'Anti-Nuke Rally', Alice Walker offered a personal dilemma she faced in relation to her involvement with antinuclear activism. Walker began her address by articulating her reluctance to endorse antinuclear politics. Walker's 'problem' with supporting nuclear disarmament is the 'hope for revenge' that she believed to be 'at the heart of People of Color's resistance to any anti-nuclear movement'. She suggests that the idea of nuclear apocalypse as a just consequence of white racial chauvinism might seduce the peoples of the African diaspora into renouncing opposition to nuclear weapons. Considering 'the enormity of the white man's crimes against humanity', including contemporary racist discourse arguing 'Blacks are genetically inferior and should be sterilized', Walker wonders whether extinction alone will stop the white man's destructive course: 'Let the bombs cover the ground like rain. For nothing short of total destruction will ever teach them anything.' Would extinction now not be preferable to a future of exponential white domination? '[It] would be good, perhaps, to put an end to the species in any case, rather than let white men continue to subjugate it'. The white men's rapacious course has designs on the universe and Walker believes 'Fatally irradiating ourselves [...] to save others from what Earth has already become' requires our 'serious thought'. ${ }^{91}$

This opening rhetoric is clearly intended to shock her audience in order to impress upon them how deeply felt Walker's indignation at white supremacism is. Her speech concludes with renewed support for the antinuclear cause. Walker seeks to retain the anger at racial injustice that fuelled her entertainment of the desirability of nuclear extinction, allying that emotion to hope for change in the future. As her home, Walker pledges to protect the Earth, and she affirms the desirability of life. Linking nuclear genocide with racial oppression, the Earth will only be spared and humankind saved on the precondition of justice for 'every living thing'. ${ }^{92}$ Extinction can only be averted if humankind manages to think outside of modernity's division of peoples into hierarchies of race.

This is the message contained in The Fire Next Time; Baldwin opposes 
racial hierarchies and nuclear stockpiling in the name of national security by calling for the 'transcendence of the realities of colour, of nations, and of altars' ${ }^{93}$ While Baldwin was writing these words in the early 1960s, a similar project could be discerned in the Committee for Nonviolent Action. Antinuclear and antiracist, the Committee for Nonviolent Action supplemented marching against segregation through Albany, Georgia with protests against the US military at an Army Supply Depot in Oakland, California. In 1966, Gerald J. Ringer called this a 'loose-but-conscious alliance of the movements for civil rights and world peace', affirming 'human dignity and human solidarity in terms of the present human condition'. ${ }^{94}$ The Fellowship of Reconciliation was another organization protesting for civil rights and against nuclear weapons. ${ }^{95}$ Appropriately for the transatlantic roam of black Atlantic studies, in 1958 a member of both organizations, Bayard Rustin, connected his civil rights and peace activism in a speech delivered in London's Trafalgar Square. This speech was part of the events surrounding the Aldermaston march, a famous moment in the history of the British Campaign for Nuclear Disarmament. The march, which took place during Easter week, began at the nuclear facility at Aldermaston in the county of Berkshire and concluded in Trafalgar Square; in his speech Rustin linked 'the struggle against weapons of mass destruction with the struggle of blacks for their basic rights in America'. ${ }^{96}$ Belonging to various civil rights and antinuclear movements (in addition to the ones above, Rustin was a member of the Peacemakers and the Southern Christian Leadership Conference), he saw the utility of pacifist non-violence and was organizing civil disobedience protests on interstate buses in 1947. ${ }^{97}$

In 1959, Rustin worked again with the British antinuclear movement. The Committee for Nonviolent Action and the British Direct Action Committee planned to

march from Accra, Ghana, to a French nuclear installation in the Sahara, 2,000 miles to the north. Here, they protested nuclear proliferation and the introduction of weapons research to Africa. The groups enjoyed the tacit approval of local governments that opposed nuclear weapons and testing but lacked the power to confront France directly. The French army stopped the marchers on the Upper Volta frontier, but Rustin had helped link disarmament to African desires for neutrality and peaceful development. ${ }^{98}$

Rustin actually returned to the USA shortly after the march started, following pressure from Martin Luther King Jr and others for Rustin to resume domestic civil rights activism. ${ }^{99}$ He accompanied King on his journey to Europe to accept the Nobel Peace Prize in 1964, arranging a 
stop in London for King to address a fund-raiser for the British peace movement. ${ }^{100}$ An antinuclear spirit suffused the Nobel Lecture that King gave on 11 December 1964, when he stated, 'mankind's survival is dependent upon man's ability to solve the problems of racial injustice, poverty, and war'. This was hardly a new concern of King's - his wife, Coretta Scott King, was one of the founders of the Committee for a Sane Nuclear Policy (SANE) in 1957. In his Nobel Lecture, King specifically warned of nuclear weapons, 'which threaten the survival of mankind, and which are both genocidal and suicidal in character'. King was acutely aware that the perception of racial difference and the repercussions of racial injustice were now more than ever at the forefront of questions around human survival. Less than two months earlier, "the detonation of an atomic device by the first nonwhite, non-Western, and so-called underdeveloped power, namely the Chinese People's Republic, opens [...] vast multitudes, the whole of humanity, to insidious terrorization by the ever-present threat of annihilation'. King argued for the translation of non-violence, the philosophy and strategy of the civil rights movement, into the sphere of international relations. ${ }^{101}$ The relevance of non-violence to the threat of nuclear war is compelling and radical; defence in the Cold War era was maintained by the presumption neither superpower would launch a nuclear attack on the other for fear of retaliation, therefore deterring both from a first strike and ensuring the peace. Rather than mimicking this system where the threat of retaliation kept the peace, King's philosophy deconstructed its logic. His belief 'nonviolence is the answer to the crucial political and moral questions of our time' represented its antithesis. Such a system of defence had no place in the future King presented in Oslo: 'man must evolve for all human conflict a method which rejects revenge, aggression, and retaliation' ${ }^{102}$ Non-violent struggle must be used to roll back racial injustice and the threat of nuclear war in tandem: 'Equality with whites will hardly solve the problems of either whites or Negroes if it means equality in a society under the spell of terror and a world doomed to extinction.' ${ }^{\prime 103}$

Kinchy sees in King's peace activism the legacy of W. E. B. Du Bois. Du Bois dedicated the last stage of his life, from the late 1940s to his death in 1963, to promoting world peace through antiracism, anticolonialism and 'opposing the cold war escalation'. Du Bois led the American delegation at the World Peace Congress in Paris in April 1949 and as chair of the Peace Information Center he actively supported the World Peace Appeal, an international petition calling for the outlawing of atomic weapons. Paul Robeson, who attended the meetings of the PIC's Executive Committee, exhorted American workers to sign the petition by connecting their plight 
to that of colonized peoples. 'The Afro-American community was a conscious and special target of the Appeal', and their response was 'disproportionately favourable'. The World Peace Appeal seems to have attracted between 1.35 and 2.5 million signatures in the USA, and signatories were as varied as Albert Einstein, Leonard Bernstein and Charlie Parker (Parker was an 'avid' supporter of the Appeal). ${ }^{104}$

By the early 1980s, the intersection of civil rights and peace movements was being redefined by black feminism. In seeking to build 'a new antiwar movement unlike the old peace movement which excluded so many oppressed people', ${ }^{105}$ black feminism and allied lesbian and gay groups demonstrated a commitment to issues of global significance, pre-empting criticism of their agenda as limited. Barbara Smith responded to such criticism by asserting that 'a movement committed to fighting sexual, racial, economic, and heterosexual oppression [...] at the same time that it challenges militarism and imminent nuclear destruction is the very opposite of narrow' ${ }^{106}$ Antinuclear protest served a double role for black feminism in this period: as a further battleground for activism and as an emblem of the movement's importance beyond identity politics. In a permutation of the black Atlantic as a counterculture of modernity, Smith believes black women have a privileged position of critical purchase, since women of colour 'comprehend white-male values and culture in a way that white men have never remotely understood themselves' ${ }^{107}$

I want to conclude this chapter with the poems 'Who Would Be Free, Themselves Must Strike the Blow' and 'From Sea to Shining Sea' by June Jordan, the latter of which was published in Barbara Smith's collection Home Girls: A Black Feminist Anthology (2nd edn, 2000). Jordan's status as a black political activist and poet is well known, and alongside other major poets such as Amiri Baraka, Jordan participated in the 'Poets against the End of the World' event at New York City's Town Hall in June 1982. ${ }^{108}$ Jordan's literary protests against the USA's nuclear weapons pick up the connections being made by activists like Smith and Gwendolyn Rogers, National Co-ordinator of the Lesbian and Gay Focus of the People's AntiWar Mobilization. Smith and Rogers contended that black feminism's political programme ranges widely but coherently because at its 'core' is the issue 'of our community's survival', ${ }^{109}$ and family and community survival is the kernel of Jordan's antinuclear, antiracist poetry.

Amongst other factors, 'Who Would Be Free, Themselves Must Strike the Blow' unsettles because it is not clear whether the images offered belong to a world of nuclear tests irradiating the food chain and water cycle, or the outbreak of nuclear war. Jordan exploits residual fears from the 1950s that the radiation from nuclear tests could poison children via 
cows' milk containing Strontium-90. ${ }^{110}$ In the poem, each stanza begins, 'The cow could not stand up' and by the third and final stanza one is informed, 'The milk should not be sold'. ${ }^{111}$ Simplicity of language and the repetition of sentences such as 'It was pretty quiet' imply a child's reading scheme, and an innocent, unprejudiced way of looking at the world that is betrayed by the severity of the crime being committed against citizens. 'It was pretty quiet' is also one of the poem's themes - radiation's danger is felt through its effects (such as disfigured babies in utero) and is not something glowing and humming, as in some popular cultural representations. Deadly radiation is silent, and the absence of noise is also a signal of the planet's gradual journey towards the extinction of human and animal life. Further, Jordan could be warning (Warnings was the title of the 1984 anthology in which the poem was published) that not enough is being done to protest nuclear weapons; her poem connects political silence to the winding down of life. The failure of antinuclear activists to make sufficient noise now will mean the quiet of extinction in the future. What makes this poem's antinuclear position relevant in terms of the black Atlantic is its title. The line comes from Lord Byron's long poem 'Childe Harold's Pilgrimage' (1812-18), in an address to the Greeks who were 'Trembling beneath the scourge of Turkish hand, / From birth till death enslav'd'. In an exhortation that is all the more convincing for being an imperative question, Byron hailed the Greeks as 'Hereditary bondsmen!' and asked them 'know ye not / Who would be free themselves must strike the blow?'112 Jordan, however, attributes this to Frederick Douglass, who reused Byron's line in the 1863 article 'Men of Color, To Arms!' Douglass is best known for the series of narratives he wrote recounting his experiences as a slave and his escape to the north, starting with Narrative of the Life of Frederick Douglass, an American Slave, Written by Himself (1845). 'Men of Color, To Arms!' urged African-American men to join the Massachusetts regiment that was recruiting black soldiers for the Union army in the US Civil War. Douglass proclaims that the men who do not sign up are held back by weakness, cowardice and 'timidity', and he reuses Byron's line without the question mark, ${ }^{113}$ turning it into an inarguable truism. In taking Douglass's assertion that African Americans must participate physically in the battle to eradicate slavery, Jordan invites comparison between the system of chattel slavery and the nuclear threat similar to the comparisons observed above. For instance, Jordan's line 'The mother could not do anything about the baby' indicates the powerlessness of parents as they try to protect their children, echoing Baldwin's comment on the male slave's sorrow that his 'children [...] needed his protection [but] he could not protect [them]'. Explicitly connecting her poem to Douglass and not 
Byron, Jordan suggests antinuclear activists should show the bravery and commitment that was asked of the African Americans who fought in the Civil War. Stone believes the acknowledgment of Douglass explicitly politicizes Jordan's poem. ${ }^{114}$ Drawing on Douglass's words as a historical resource from the struggle against slavery, one is reminded that a nuclearfree world cannot be willed - it must be fought for.

According to Richard Gray's A History of American Literature (2004), this will to resist oppression is characteristic of Jordan's poetry. Perceiving a history of violence in which black women have been disproportionately victimized, she uses her writing to 'fight back'. ${ }^{115}$ In 'From Sea to Shining Sea', Jordan fights a battle for meaning and the idea of nature is the site of the struggle. The poem catalogues the social injustices of the USA in 1980: the murder of homosexuals by religious extremists, the murder of black Americans by 'the Klan / and the American Nazi Party', the streamlining of education and social service provisions, the deregulation of workplace safety codes and hostility towards the Equal Rights Amendment. In light of Jordan's lists, one can read the repeated line 'Natural order is being restored' as the mantra of the conservative social forces whose hegemony was challenged by the various civil rights agendas of the 1960s and 1970s. Writing in 1980, those challenges are being rolled back by the American state and previously marginalized groups are going neglected and abused by the state once more. In the terms of the poems, those believing themselves to benefit from this reinstated marginalization construct their centrality as the natural order, or 'just how things are'. Jordan associates this conservative social reaction with America's nuclear technology: the inhabitants of Queens in New York City are exposed to 'explosive nuclear wastes' transported through their streets, Arkansans are alarmed by 'Occasional explosions caused by mystery / nuclear missiles', and the nuclear missile base in Grand Forks, North Dakota makes 'the nonmilitary residents of the area feel / that they live only a day to day distance from certain / annihilation, etcetera'. ${ }^{116}$ That 'etcetera' is one of a series of rhetorical appendages that Jordan uses in describing violence and marginalization ('among other things' and 'and so on' being two other examples) to convey America's political leaders' aloofness from and disinterest in the concerns of their fellow citizens. Kawada reads the placing of 'etcetera' after 'annihilation' as ironic, asking 'what could the "etcetera" after annihilation be, anyway?' She understands Jordan to be parodying the language of the nuclear state, which is officious but defies reason, such as the fallacy of survival after nuclear war. ${ }^{117}$

Each instance of violent and institutional marginalization can be understood within Jordan's controlling metaphor of a pyramid of 104 
pomegranates in a supermarket, immaculate consumer goods whose status as a spectacle erases their usage as food (at least in Jordan's view). Like the pomegranates, instances of social injustice rest on top of each other in a capitalist order that erroneously professes to be the natural order. Against this false recourse to natural order, Jordan poses 'natural disorder' and the messy and disintegrating pleasure of eating a pomegranate. Her ecstatic language, 'This is a good time / This is the best time', viscerally thrills to the pomegranate's 'succulence' and the poem solicits the reader's participation in this natural disorder, which is

Fractious
Kicking
Spilling
Burly
Whirling
Raucous
Messy
Free

Exploding like the seeds of a natural disorder. ${ }^{118}$

Jordan's resistance to America's racist, nuclear-armed order is articulated in language that embodies the liberation she hopes for the future. This spirit of disorder is the seed of civil disobedience refusing to allow the legal enshrinement of certain types of social inclusion achieved in the 1960s and 1970s to be rolled back by people who believe that homophobia, racism and nuclear weapons are part of a natural order. Through the pomegranate metaphor, Jordan builds a poetic case for the tangible pleasures of disorderliness, appropriate for the coalition activism of early 1980s America and nodding towards the civil rights movement's civil disobedience, too. In excoriating the state of a nuclear-armed and racist United States, hope is provided by the memory of historical black freedom struggles.

As we have seen, positing the whiteness of nuclear weapons has provided a variety of opportunities for black Atlantic texts to explore the hypocrisies and tensions of modernity. One recurrent permutation was how the threat of nuclear extinction evidences the white West's lack of racial superiority or technological advancement, despite historical proclamations to the contrary. The most useful texts have not sought a mythic space outside modernity where redemption awaits. Rather, they accept no complete rejection of modernity is possible. What remains viable is charging modernity to realize its mandate of progress, justice and emancipation, and this can only take place when the delusion that skin colour 
has any value is transcended, along with the destructive applications of nuclear technology.

\section{Notes}

1. Martin Luther King Jr, Why We Can't Wait (1964), New American Library, New York (2000), p. 7, quoted in Alice L. George, Awaiting Armageddon: How Americans Faced the Cuban Missile Crisis, University of North Carolina Press, Chapel Hill (2003), p. 162. 19.

2. Simone de Beauvoir, The Second Sex (1949), Vintage, London (1997), p.

3. Paul Gilroy, The Black Atlantic: Modernity and Double Consciousness (1993), Verso, London (1996), pp. 1-40.

4. Gilroy, The Black Atlantic, p. 38.

5. Tania Abdulahad, Gwendolyn Rogers, Barbara Smith and Jameelah Waheed, 'Black Lesbian / Feminist Organizing: A Conversation', in Barbara Smith (ed.), Home Girls: A Black Feminist Anthology (2nd edn), Rutgers University Press, New Brunswick, NJ (2000), p. 291.

6. Mark Sinker, 'Loving the Alien' (1992), The Wire, available at http://www.thewire.co.uk/articles/218/ (last accessed August 2010).

7. Albert E. Stone, Literary Aftershocks: American Writers, Readers, and the Bomb, Twayne, New York (1994), p. 21.

8. Norman Mailer, 'The White Negro: Superficial Reflections on the Hipster' (1957), in idem, Advertisements for Myself (1959), Deutsch, London (1961), pp. 283-85. See also Donna Akiba Sullivan Harper, Not So Simple: The 'Simple' Stories by Langston Hughes, University of Missouri Press, Columbia, MO (1995), pp. $51-52$.

9. Thomas H. Schaub, American Fiction in the Cold War, University of Wisconsin Press, Madison (1991), pp. 145-46, 155.

10. James Baldwin, The Fire Next Time (1963), Penguin, Harmondsworth (1964), p. 67.

11. Quoted in Boyer, By the Bomb's Early Light, p. 269.

12. Baldwin, The Fire Next Time, p. 84.

13. Baldwin, The Fire Next Time, p. 53.

14. See also Aldous Huxley, Ape and Essence (1949), Chatto \& Windus, London (1966), p. 37.

15. Baldwin, The Fire Next Time, p. 84.

16. Shohat and Stam, Unthinking Eurocentrism, pp. 3, 14.

17. Cooper, 'The Whiteness of the Bomb', p. 86.

18. Gilroy, The Black Atlantic, p. 39.

19. Kinchy, 'African Americans in the Atomic Age', p. 296.

20. Stone, Literary Aftershocks, p. 38. See also Boyer, By the Bomb's Early Light, p. 199.

21. Boyer, By the Bomb's Early Light, pp. 198-99.

22. Langston Hughes, The Best of Simple, Hill and Wang, New York (1961), pp. 210-11. Dates given in brackets for the Simple stories refer to the year of 
publication in collected editions rather than the original date of publication in the Chicago Defender. Hughes extensively revised the stories for these collected editions, a process documented in Harper, Not So Simple.

23. Hughes, The Best of Simple, p. 201.

24. Allan M. Winkler, Life under a Cloud: American Anxiety about the Atom, Oxford University Press, New York (1993), p. 94.

25. Hughes, The Best of Simple, p. 202.

26. Langston Hughes, Simple's Uncle Sam, Hill and Wang, New York (1965), p. 122.

27. Hughes, Simple's Uncle Sam, p. 123.

28. Malcolm X, with the assistance of Alex Haley, The Autobiography of Malcolm X (1965), Penguin, London (2001), p. 373.

29. Jonathon Schell, The Fate of the Earth, Avon, New York (1982), p. 37.

30. Olive Senior, 'rain' (1985), in E. A. Markham (ed.), Hinterland: Caribbean Poetry from the West Indies $\theta$ Britain (2nd edn), Bloodaxe, Newcastle-upon-Tyne (1995), p. 226.

31. Edward Brunner, Cold War Poetry, University of Illinois Press, Urbana, IL (2001), p. 223.

32. Quoted in Brunner, Cold War Poetry, p. 194.

33. Brunner, Cold War Poetry, p. 240.

34. Quoted in Henrikson, Dr. Strangelove's America, p. 283.

35. Quoted in Kinchy, 'African Americans in the Atomic Age', p. 310.

36. Henrikson, Dr. Strangelove's America, p. 283.

37. Langston Hughes, Selected Poems (1959), Serpent's Tail, London (1999), p. 268.

38. Hughes, Selected Poems, p. 280.

39. Hughes, The Best of Simple, p. 211.

40. Baldwin, The Fire Next Time, p. 89.

41. Henrikson, Dr. Strangelove's America, pp. 284-86.

42. Shohat and Stam, Unthinking Eurocentrism, pp. 2-3.

43. Baldwin, The Fire Next Time, p. 53.

44. Baldwin, The Fire Next Time, p. 53.

45. Percy Bysshe Shelley, 'Mont Blanc' (1816), in Neville Rogers (ed.), The Complete Poetic Works of Percy Bysshe Shelley (vol. II), Clarendon Press, Oxford (1975), pp. 78-80.

46. Edward Kamau Brathwaite, 'Mont Blanc' (1987), in E. A. Markham (ed.), Hinterland: Caribbean Poetry from the West Indies $\theta$ Britain (2nd edn), Bloodaxe, Newcastle-upon-Tyne (1995), p. 126.

47. Brathwaite, 'Mont Blanc', pp. 126-27.

48. Hughes, The Best of Simple, p. 201.

49. Sharp, Savage Perils, p. 207.

50. Hughes, The Best of Simple, p. 211.

51. Hughes, Simple's Uncle Sam, p. 55.

52. Hughes, The Best of Simple, p. 211.

53. Hughes, Simple's Uncle Sam, p. 54.

54. Harper, Not So Simple, p. 178. 
55. Hughes, Simple's Uncle Sam, p. 54.

56. Sharp, Savage Perils, p. 197.

57. Hughes, Simple's Uncle Sam, p. 54.

58. Hughes, Simple's Uncle Sam, p. 55.

59. Gilroy, The Black Atlantic, pp. 201-205.

60. Hughes, The Best of Simple, pp. 213, 212.

61. Hughes, Simple's Uncle Sam, p. 55.

62. Hughes, Simple's Uncle Sam, p. 33.

63. Joel Kovel, Against the State of Nuclear Terror, Pan, London (1983), p. 70. See also Robert Jay Lifton and Richard Falk, Indefensible Weapons: The Political and Psychological Case against Nuclearism, Basic Books, New York (1982), p. 18.

64. Hughes, Simple's Uncle Sam, p. 98.

65. Hughes, Simple's Uncle Sam, pp. 34-36.

66. Bertrand Russell, 'The Case for British Nuclear Disarmament' (1962), in Morton Grodzins and Eugene Rabinowitch (eds), The Atomic Age: Scientists in National and World Affairs, Basic Books, New York (1963), p. 292.

67. Henrikson, Dr. Strangelove's America, p. 193. See also Brians, Nuclear Holocausts, p. 21.

68. Henrikson, Dr. Strangelove's America, p. 200. See also Boyer, By the Bomb's Early Light, p. 353.

69. Henrikson, Dr. Strangelove's America, pp. 203, 215. See also Seed, American Science Fiction and the Cold War, p. 87.

70. Sharp, Savage Perils, pp. 206-207.

71. Gilroy, Against Race, pp. 56-64.

72. Derek Walcott, 'The Muse of History', in Orde Coombs (ed.), Is Massa Day Dead? Black Moods in the Caribbean, Anchor and Doubleday, Garden City, NY (1974), p. 6.

73. Ishmael Reed, Mumbo Jumbo, Doubleday, Garden City, NY (1972), p. 162.

74. Donald L. Hoffman, 'A Darker Shade of Grail: Questing at the Crossroads in Ishmael Reed's Mumbo Jumbo', Callaloo, 17.4 (Autumn 1994), p. 1246.

75. Reed, Mumbo Jumbo, pp. 173, 186, 91.

76. Cooper, 'The Whiteness of the Bomb', p. 89.

77. Reed, Mumbo Jumbo, pp. 91, 16.

78. Cooper, 'The Whiteness of the Bomb', p. 90.

79. Richard S. Leghorn, 'A Rational World Security System' (1957), in Morton Grodzins and Eugene Rabinowitch (eds), The Atomic Age: Scientists in National and World Affairs, Basic Books, New York (1963), p. 260.

80. Franklin, War Stars, p. 183.

81. Franklin, War Stars, p. 191; To Mars by A-Bomb: The Secret History of Project Orion, dir. not attributed, prod. Christopher Sykes, BBC 2 (12 Nov. 2003).

82. Quoted in Shohat and Stam, Unthinking Eurocentrism, p. 110.

83. Alice Walker, 'Only Justice Can Stop a Curse' (1982), in Barbara Smith (ed.), Home Girls: A Black Feminist Anthology (2nd edn), Rutgers University Press, New Brunswick, NJ (2000), p. 341.

84. Hughes, Simple's Uncle Sam, pp. 28-29. 
85. Hughes, Simple's Uncle Sam, pp. 28-29.

86. Quoted in Kinchy, 'African Americans in the Atomic Age', p. 307.

87. Hughes, The Best of Simple, pp. 55, 57.

88. Hughes, The Best of Simple, pp. 56-57.

89. Walter Mosley, 'Black to the Future', in Sheree Thomas (ed.), Dark Matter: A Century of Speculative Fiction from the African Diaspora, Aspect and Time Warner, New York (2000), p. 205.

90. Hughes, The Best of Simple, p. 57.

91. Walker, 'Only Justice Can Stop a Curse', pp. 340-41.

92. Walker, 'Only Justice Can Stop a Curse', p. 342.

93. Baldwin, The Fire Next Time, p. 72.

94. Gerald J. Ringer, 'The Bomb as a Living Symbol: An Interpretation', PhD Dissertation, Florida State University (1966), pp. 289-91.

95. Kinchy, 'African Americans in the Atomic Age', p. 297.

96. Jervis Anderson, Bayard Rustin: Troubles I've Seen, University of California Press, Berkeley (1998), p. 215.

97. Kinchy, 'African Americans in the Atomic Age', pp. 312-13.

98. Brenda Gayle Plummer, 'Introduction', in idem (ed.), Window on Freedom: Race, Civil Rights, and Foreign Affairs 1945-1988, University of North Carolina Press, Chapel Hill (2003), pp. 13-14.

99. Kinchy, 'African Americans in the Atomic Age', pp. 312-13 n. 71.

100. Plummer, 'Introduction', p. 14.

101. Martin Luther King Jr, 'Nobel Lecture: The Quest for Peace and Justice' (11 Dec. 1964), available at Nobelprize.org, http://nobelprize.org/nobel_prizes/ peace/laureates/1964/king-lecture.html (last accessed August 2010).

102. Martin Luther King Jr, 'Acceptance Speech' (10 Dec. 1964), available at Nobelprize.org, http://nobelprize.org/nobel_prizes/peace/laureates/1964/ king-acceptance.html (last accessed August 2010); emphasis added.

103. King, 'Nobel Lecture'.

104. Gerald Horne, Black and Red: W. E. B. Du Bois and the Afro-American Response to the Cold War, 1944-1963, State University of New York Press, Albany, NY (1986), pp. 126-27; Kinchy, 'African Americans in the Atomic Age', pp. 298-304, 313.

105. Abdulahad, Rogers, Smith and Waheed, 'Black Lesbian / Feminist Organizing: A Conversation', p. 291. The evidence in this chapter demonstrates the old peace movement was not as exclusive as this quotation suggests.

106. Barbara Smith, 'Introduction', in Barbara Smith (ed.), Home Girls: A Black Feminist Anthology (2nd edn), Rutgers University Press, New Brunswick, NJ (2000), p. xxxi.

107. Barbara Smith, “Fractious, Kicking, Messy, Free”: Feminist Writers Confront the Nuclear Abyss', in Jim Schley (ed.), Writing in a Nuclear Age (1983), University Press of New England, Hanover (1984), p. 169.

108. Walter Kalaidjian, 'Nuclear Criticism', Contemporary Literature, 40.2 (Summer 1999), p. 315.

109. Smith, 'Introduction', p. xxxvii.

110. Winkler, Life under a Cloud, pp. 102-103. 
111. June Jordan, 'Who Would Be Free, Themselves Must Strike the Blow', in John Witte (ed.), Warnings: An Anthology on the Nuclear Peril, Northwest Review, Eugene, OR (1984), p. 38.

112. George Gordon, Lord Byron, 'Childe Harold's Pilgrimage' (1812-18), in Jerome J. McGann (ed.), The Complete Poetical Works (vol. II), Clarendon Press, Oxford (1980), p. 69.

113. Frederick Douglass, 'Men of Color, To Arms!' (1863), in William L. Andrews (ed.), The Oxford Frederick Douglass Reader, Oxford University Press, New York (1996), p. 224.

114. Stone, Literary Aftershocks, p. 142.

115. Richard Gray, A History of American Literature, Blackwell, Malden, MA (2004), p. 671.

116. June Jordan, 'From Sea to Shining Sea' (1980), in Home Girls: A Black Feminist Anthology (2nd edn), Rutgers University Press, New Brunswick, NJ (2000), pp. 215-20.

117. Louise Kawada, 'Enemies of Despair: American Women Poets Confront the Threat of Nuclear Destruction', PLL: Papers on Language $\theta$ Literature, 26.1 (Winter 1990), p. 130.

118. Jordan, 'From Sea to Shining Sea', p. 221. 


\section{Race and the Manhattan Project}

No universal history leads from savagery to humanitarianism, but there is one leading from the slingshot to the megaton bomb.

Theodor Adorno ${ }^{1}$

Anglo-Saxon science has developed a new explosive 2,000 times as destructive as any known before.

H. V. Kaltenborn, News Report, NBC $(6 \text { August 1945) })^{2}$

So we strive to save civilization, and we learn how to wreck it, all on the same weekend.

Raymond Gram Swing, on the eve of the atomic bomb test at Bikini

(1 July 1946) ${ }^{3}$

This chapter discusses three novels set during the USA's project to construct the first atomic bomb. These novels, each written during a different period of the Cold War, explicitly refer to the racial politics of the Manhattan Project, and in particular the contested assumption that the first atomic weapons were white (specifically Anglo-Saxon) bombs. This assumption is made by characters within these novels, and was present in the US media of the period. Writing in the Chicago Defender in September 1945, NAACP Executive Secretary Walter White criticized Winston Churchill's desire to keep the bomb under 'Anglo-Saxon' control. The same month, Roy Wilkins wrote an editorial in the NAACP magazine The Crisis linking the atomic bombing of Japan to the racist perception of Japanese subhumanity and asked 'Who is barbarian and who is civilized?' ${ }^{4}$

The successful development of this new military technology was publicly announced after the atomic bombs had been used against the Japanese cities of Hiroshima and Nagasaki, and the assumption outlined above was not the dominant one in the American press. Instead, the significance of Nazi Germany's persecution of the Jews in the race to build an atomic weapon was emphasized: several periodicals commented that the Manhattan Project scientists had originally lived in Europe and migrated 
to the United States to avoid persecution. Journalists posed this as a just repercussion of Nazism's anti-Semitic policies: fascist intolerance drove away the scientists capable of building a weapon to win the war, whereas the special conditions of the United States (and only those conditions) made the building of the first atomic bomb possible. ${ }^{5}$ One such condition was America's class and ethnic diversity, as Time magazine noted in 1945: 'Professors, including many Nobel Prize winners, deserted their campuses to live in dusty deserts. Workers trekked in their trailers - careful New England craftsmen, burly Southern Negroes, all the races and types of the great U.S.' ${ }^{6}$ Historian Paul Boyer notes that proponents 'of this theme stressed the diverse national origins of the key Manhattan Project scientists: the Italian Fermi, Bohr from Denmark, the Hungarian Szilard, Einstein and Franck from Germany, Oppenheimer, Compton, and others from the United States'; 'American democracy' and the country's freedom from prejudice supposedly contributed to the Project's success. ${ }^{7}$ The major African-American newspapers similarly 'emphasized that African-American scientists [...] had contributed to building the bomb [and were] American heroes, equal to the whites in their contributions' ${ }^{8}$

One might expect novels depicting the US atomic-bomb programme to echo the atmosphere of racial tolerance and to contend that this inclusive climate permitted the intellectual cross-fertilization necessary for the Project's success. However, the novels discussed in this chapter argue that the Manhattan Project, principally based in Los Alamos, New Mexico, was a success in spite of American racism. In these representations, the United States is afflicted by profound institutional racism, especially anti-Semitism, partly through the perceived threat Jews represent, and partly because of the virulent anticommunism, dominant in mid-twentiethcentury American society, that understood European Jews as carriers of infectious Marxist ideology.

Dexter Masters's novel The Accident (1955), from the first period of heightened Cold War tension, uses its protagonist's experiences to expose how the extreme anti-Semitism the United States projected onto Nazism since World War Two elides America's own racial intolerance. ${ }^{9}$ The Accident argues for the meaninglessness of racial categories while highlighting how endemic race thinking has become. Masters's novel shows that the racism and acceptance of immutable racial difference disfiguring Nazi Germany, against whom the USA raced to build an atomic bomb, are equally present in American society.

In Stallion Gate (1986), written by Martin Cruz Smith during the 1980s resurgence of Cold War hostilities, protagonist Joe Peña (a Native American security officer at Los Alamos) is a witness and victim of racism. 
Ordered to incriminate J. Robert Oppenheimer, the Jewish scientific director of the Manhattan Project, as a spy by an anti-Semitic superior, Joe must negotiate a network of racial sanctions and roles as the narrative progresses. One of the ways Stallion Gate complicates hierarchies of race is through Joe's hybrid identity. However, Joe's racial identity starts to coagulate towards the novel's end, particularly when Oppenheimer's racist vitriol stimulates Joe's allegiances to other Native Americans. The novel ends without resolution, and I argue this narrative move is necessitated by the novel's ambivalent position on Joe's place in the racial hierarchies of Los Alamos: Joe's racial identity can only remain unfixed if the novel suspends any indication of his future existence after the events in the novel.

Joseph Kanon's Los Alamos (1997) was published after the end of the Cold War, and over 50 years since the defeat of Nazi Germany and the atomic bombing of Japan. Unlike the two previous novels, the protagonist of Los Alamos, Mike Connolly, is an Irish American easily accepted within the edifice of American whiteness. Investigating the murder of a Jewish security officer, Connolly encounters several émigré Jewish scientists hoping to use the Manhattan Project to strike back at Nazism. Los Alamos warns that the atomic bomb may be about to become a weapon used in a global battle between warring races, but paradoxically insists on the appropriateness of racial loyalty.

In all three novels, the Holocaust retains its status as the ultimate racist atrocity. However, racial categories seem strongest in the most recent novel. The anti-Semitism cited in the novels often takes place because its proponents rhetorically situate Jews outside of humanity and civilization. As noted earlier, the term 'civilization' is not a value-free concept, nor is it a universal one. Referring to an advanced stage of humankind, the term legitimized the exposure of non-Europeans to European culture, and seemingly explained the technological superiority that made expansion possible. The political utility of civilization has made the concept appropriable in times of war as the ultimate justification for one's actions. The public pronouncements in the USA surrounding the end of World War Two hailed the national qualities that the Manhattan Project embodied: no 'country except the United States, with its industrial know-how', ${ }^{10}$ was sufficiently affluent, democratic, pluralist and technologically developed to bring such a project to fruition. On 20 August 1945, Time magazine proclaimed 'the weapon had been used by those on whom civilization could best hope to depend'. ${ }^{11}$ However, the racial tolerance of the United States and the quality of its 'civilization', both part of the interpretation of the Manhattan Project in the public debates of the mid-1940s, are extensively questioned in The Accident, Stallion Gate and Los Alamos. 


\section{American Anti-Semitism}

Dexter Masters's The Accident is narrated through a series of flashbacks, unfolding in Los Alamos immediately after World War Two, set against the ongoing objective of the Manhattan Project to develop more powerful nuclear weapons. The title refers to an accident exposing the physicist Louis Saxl to a fatal dose of radiation, in which he knocked over an experimental uranium pile to save the lives of others. ${ }^{12}$ The novel explores the anti-Semitism Saxl has faced across American society, contradicting the official postwar narrative of American racial tolerance that supposedly sealed victory in 1945. The Accident shows how antiracist and anti-Semitic characters alike assume the ' $\mathrm{Jew}^{\prime}$ ' is a discernable racial category, and against that categorization, the novel collapses the legibility of racial distinctions.

Assumptions about Jewishness occur early on in the novel. Louis Saxl perplexes one of the soldiers guarding the Manhattan Project because Saxl confounds his physiological expectations:

[The soldier] is puzzled by Saxl's failure to look like other Jews he has known. The soldier has studied Saxl covertly [...] and is puzzled further because Saxl does not, he thinks, have any conspicuous feature at all, except shining eyes.

As Saxl dies slowly of radiation poisoning, his Jewishness marks him as an object of surveillance for the soldier, studying him closely in order for Saxl to fit the ideology to which the soldier adheres. The Accident reveals that Saxl was taunted as a child, 'Jew eyes!', which still haunts him in his sleep: 'how durable the old wounds were!' Constant presumptions about Jewishness have dulled Saxl's sense of offence at 'prejudice': He has learnt that it simply is not expedient to feel fully the pain of anti-Semitism, since he has experienced 'so many' moments of 'prejudice [...] that too often one reaction would not be ended before another would have to begin'. Perception of difference is not always threatening or abusive. The friends of Ben Saxl, Louis's father, are readily sympathetic about the Holocaust, but unable to see beyond Ben's Jewishness:

'You know, he never says a word about what's happening to his people in Germany [...] It must be a burden to him, though. It must be a terrible thing to think about if you're one of them.'

'They don't make them any nicer than Ben Saxl. I don't mean just for a Jew, neither.'

Ben's friends assume an uncomplicated racial affinity stretching across the Atlantic to include all Jews; the victims of Nazi anti-Semitism are Ben's 
'people', he is 'one of them', and the language of the first speaker not only asserts that Ben belongs to the Jews, but that the Jews are a group identifiably distinct from 'us' and their fate is automatically assumed not to be a burden of 'ours'. The second speaker commends Ben for reaching the spectacularly unprecedented status of being valued on his own terms, not just when judged against his race. This speaker implies if a Jew is recognized for his sociability, it is usually from a sliding scale adjusted to a behavioural bedrock of Jewish coolness. In fact, Ben Saxl chooses not to think about the extermination of European Jews. They 'were as remote as the Poles. In this he was much like most of his neighbours; he was only expected to be different. ${ }^{13}$ The perception of Jewish difference expects Jews to think and behave in ways unlike Gentiles. The possibility that Ben's friends do not entertain is that Jewish thoughts and actions are not traceable to a unique racial essence, but come to being in a shared social context of which all Americans, including Jewish Americans, are part.

American anti-Semitism and casual references to Jewish difference collide in a flashback in The Accident from the eve of war in Europe, as Louis Saxl enters the restaurant-garden of Mr. Biscanti. A young American man defends isolationism, speaking 'about strength, morality, the German genius, Jews and Poles, the Versailles Treaty, certain admitted excesses of the men around Hitler, and now was on the unmistakable dedication of the latter'. In contesting the young man's speech, one of his opponents calls for Saxl to intervene:

'Hey Saxl [...] come on out here. We've got a regular Nazi here saying a lot of things. Come on out. You're a Jew, aren't you? You tell him.'

Even as he said it he was ashamed of himself. Then he rationalized: he is a Jew, it is perfectly sensible, it only sounds bad. Then he was ashamed again, all in a second [...] Behind him the young man spoke.

'There's really no point in discussing these things with a Jew.'

In order to combat explicit anti-Semitism, the tall man mobilizes the idea of 'the Jew'. To hail Saxl as 'a Jew', to bring him into the argument as an authentic witness of racism, is to reduce him to a racial type that overlaps with the pejorative meaning of 'Jew' that the Nazi sympathizer uses. The shame that the tall man feels is an acknowledgment of this assumption; his following rationalization compounds the misjudgment by retreating into the language of self-evident difference ('he is a Jew, it is perfectly sensible'); that this self-justification is flawed brings shame again to the speaker. The tall man draws attention to Saxl's identity to invite his 
authority as a victim of anti-Semitism, but the Nazi sympathizer refuses to let him enter into the argument on those very grounds, so certain is he of racial difference (the Nazi sympathizer's 'words had been said quite reasonably, as a first principle might be stated'). The narration makes explicit the equivalence between American anti-Semitism and Nazi ideology; the young man's recourse to rational principles in the cause of racism 'was the very distillate of the reverberations that could be felt across continents and oceans'. Like those Germans disinterestedly tolerating Nazism, in $\mathrm{Mr}$ Biscanti's garden a plump man casually supports the young man's racism: 'still I suppose there's some truth to it'. Mr Biscanti physically ejects the Nazi sympathizer, but to avoid embarrassing his other customers he omits any 'references to the crime that had brought forth the punishment', maintaining the invisibility of American anti-Semitism. ${ }^{14}$

The Accident insists on the uneasiness of Saxl's position within American scientific institutions because of perceptions of his Jewishness. Before joining the Manhattan Project, Saxl is refused a 'teaching job' at a university because of anti-Semitism. An acquaintance wants to get him a good job - 'if only he weren't a Jew'. Saxl's friend Skip Seago arranges a job for Saxl upon his return in 1939 from fighting in the Spanish Civil War. Before he meets the new boss, Jessup, Seago cautions Saxl to restrain his temper and his racial pride. Seago warns that Jessup 'shoots his face off about Jews [...] he doesn't really mean anything by it [...] But he's apt to say something. Can you - handle that sort of thing, Louis?'15 Saxl's childhood friend asks him to accept anti-Semitism as unfortunate but unchangeable, something that he will have to learn not to take offence from if he is to progress in the American workplace.

Anti-Semitism is absent amongst the scientists during Saxl's time at the Manhattan Project: 'Among the people he worked and lived with there was none of it, none that he had experienced or had heard of'. In The Accident, the Holocaust haunts the community at Los Alamos, such as the fictional Jewish physicist Herzog, who came to America fleeing Nazi Germany. Saxl is described as smiling at the enormous irony of the situation' when considering the famous Einstein letter, the missive devised by the physicists Einstein and Leo Szilard, which urged President Roosevelt to begin an atomic weapon programme to compete with Germany. Einstein had been dispossessed of his home in 'Caputh, near Potsdam', and his 'apartment in Berlin'. The work of the Manhattan Project scientists is depicted as inseparable from the war in Europe. The fictional JewishHungarian physicist Voss declares, 'As of September first [1939, the day Germany invaded Poland] the theory of nuclear fission cannot be discussed without reference to politics and war.' Voss argues that an American atomic 
bomb must be produced to 'prevent a spectacular threat to civilised life', a bomb to scorch genocidal anti-Semitism from the Earth. David Thiel, another of Saxl's friends, believes the émigré physicists' heightened appreciation of what a Nazi victory would mean drives them to develop an atomic bomb first:

I know a guy here who can prove [the atomic bomb] won't work. Like you and me, he was born and brought up in the United States. But Fermi and Szilard and Wisla and Wigner and Weisskopf and Teller and some others, all here by virtue of travel more or less enforced, seem to think it will work [...] nature always gives the same answers to the same questions. But a guy running from a concentration camp maybe asks some questions harder, or refines them some, or maybe just listens harder for the answers.

Personal knowledge of Nazi atrocities concentrates the attention of these émigrés on building a weapon that will wipe the 'virus' of Nazism from the 'tissue' of Europe. This process is prefigured in The Accident by a poem written by Saxl in the mid-1930s in response to German anti-Semitism: 'pray / For the hate that will steady the knife in our own sure hand'. ${ }^{16}$

The writings of Theodor Adorno, himself a Jewish émigré living in California in the 1940s, cautions against these characters' talk of total revenge:

As long as blow is followed by counter-blow, catastrophe is perpetuated. One need only think of revenge for the murdered. If as many of the others [Nazis] are killed, horror will be institutionalized [...] If, however, the dead are not avenged and mercy is exercised, Fascism will $[\ldots]$ get away with its victory scot-free, and, having once been shown so easy, will be continued elsewhere. ${ }^{17}$

The Accident echoes Adorno's insistence on the impossibility of adjudication on Nazism's crimes. The novel refutes the claims of racial absolutes, and warns against using the atomic bomb in defence of civilization. Dr Beale, a pathologist brought to Los Alamos, who taught Saxl biology, becomes a mouthpiece in The Accident for the refutation of race, and a spokesperson for the ethical complications of America's atomic-bomb programme. Beale scorns the idea that the Jews are a different race:

Maybe Jews have more [curiosity], that's what they tell me, only I never saw it. I've known some awful dull Jews. Dull or bright, though, they always seemed to me ninety-seven per cent like everyone else. What people make out of the other three per cent! Goddammit, everybody's ninety-seven per cent like everybody else. 
Every goddamn one of us has got the blood of Tutankhamen's grandparents in him. ${ }^{18}$

Beale seems to recognize that Jews are different from 'everyone else', but confounds this by suggesting that the extent of that difference, 'three per cent', is the same measure of difference that characterizes human life in general - 'everybody's ninety-seven per cent like everybody else'. This reinforces the biological inclination that unifies humankind as a whole, 'the blood of Tutankhamen's grandparents' that we all share, and that to magnify the 'other three per cent' that Jews differ by into racial difference is erroneous, and defies the evidence of difference within Jews themselves, 'Dull or bright'. Beale's words prefigure the American Anthropological Association's position on racial difference by over 40 years: 'there is greater variation within "racial" groups than between them' ${ }^{19}$

It is also Beale who reflects critically on the atomic bomb. It may not be American civilization's weapon against Nazism but an expression of Europe's self-destruction during World War Two: 'Does it give you pause that virtually all of the science that went into this project came out of Europe?' In Beale's interpretation, the hatred seen in the Holocaust will not be destroyed by, but is concentrated in, America's atomic bomb. For Beale, this device serves neither civilization nor humankind; rather, the atomic bomb benefits one section of humanity (the Allies) by exterminating another (the Japanese): 'you've been serving people here with your bombs? [...] You've been serving some people at the expense of others [...] forgive me if I vomit at the mention of science serving people'. Thiel voices the similar view that America's atomic bombs are not preserving civilization. They promise an alternative future: 'civilization cannot stand up under' the pressure of a Third World War augured by the new weapons. $^{20}$

On Saxl's death by radiation poisoning, Beale's response rings with the language of poetic justice: 'I cannot honestly [...] say I feel worse about him than I did about all those people of Hiroshima and Nagasaki who were killed by the bombs he helped build.' Saxl himself had protested in advance against using the atomic bomb against Japan. In an extended flashback, he suggests the USA is parroting the Nazis' excuses for bombing defenceless populations: 'Senators and generals say this is the way modern wars are fought, which is what the Germans said when they bombed out Rotterdam.' In developing atomic bombs to defend civilization against Nazi atrocities, have the physicists of the Manhattan Project created weapons that perpetrate atrocities?

[The physicists'] failure (they feared) might mean the loss of the war 
and the beginning of barbarity. But the fear of success was no less a fear, for they were [...] preparing an instrument [...] not easily [...] separated from barbarity.

The scientific experimentation on Jewish subjects in the concentration camps was more evidence of Nazi barbarism. The spectre of this is summoned up in The Accident by a Japanese physicist's report on the radiation victims at Hiroshima and Nagasaki: 'you Americans, you are wonderful, you have made the human experiment'.$^{21}$ In Hiroshima (1946), journalist and writer John Hersey records that the survivors of the atomic bombings resented the Americans for regarding 'them as laboratory guinea pigs or rats'. ${ }^{22}$ Towards the end of The Accident, the question is posed of America and its hydrogen bombs, 'what kind of nation will they save?' The novel implies the accident that irradiated Louis was subconsciously motivated, a self-inflicted punishment for his part in the Manhattan Project. ${ }^{23}$ Comparisons can be drawn with New Zealander James George's novel Ocean Roads (2006), where the character Isaac, a Jewish physicist who has fled Europe and joined the Manhattan Project, eventually breaks down and realizes 'he has been complicit in the military irradiation of the planet'. ${ }^{24}$ In a premonition of World War Three, Thiel asks whether Saxl is 'the first casualty of what could be a second atomic war'. ${ }^{25}$ These comments correct the eagerness of the émigré Jewish scientists to build an atomic bomb. Nuclear weapons will kill Jews as easily as anti-Semites. In an era of atomic bombs, their ashes are indistinguishable from one another.

When Louis's grandfather Abraham Saxl, dying, saw Louis as a boy playing with Seago, he 'felt very happy to see Jew and Gentile, eleven and fifteen, together', ${ }^{26}$ a future of fruitful coexistence between supposedly different racial groups. There is little in The Accident to amplify this sliver of hope: the novel shows how anti-Semitism in American society survives after Nazism, and the perception of racial difference, even at its most benign, denies individual subjectivity and addresses racial spokespersons. The Accident makes legible the desire of Jewish scientists, including Saxl, to strike back against Nazism, in the form of an atomic bomb supposedly defending what is left of civilization. But that atomic bomb project is poised to escalate out of control during the nuclear arms race, and escalation is explicitly compared to the experiment that doomed Louis: 'Possibly something was done in the expectation that it would build up intensity a little - much as someone might say let's build a few more bombs and see where we are then - and instead it took the experiment right across the critical threshold. ${ }^{27}$ Beale suggests the Manhattan Project's European lineage is no coincidence, and it is to be expected that the continent that produced 
Nazism would plant in the New World a weapon as apocalyptic as the atomic bomb. Against Abraham Saxl's hopes for peaceful coexistence, The Accident characterizes the recent past, present and future as an era of genocidal racism, mass extermination technology and an American populace complicit with casual anti-Semitism. This is epitomized by the plump man in Mr Biscanti's garden, consenting (in Adorno's words) 'to a few statements that one knows ultimately to implicate murder' ${ }^{28}$ In his dying delirium, Louis calls out, 'The hate! The hate!'29 This reworking of the character Kurtz's deathbed statement, 'The horror! The horror!', from Joseph Conrad's Heart of Darkness (1899) evokes the legacy of Kurtz in the postwar world. This legacy includes the hypocritical assumption of superiority by the European colonial project in its rampant exploitation of and contempt for colonized subjects, encapsulated in Kurtz's 'Exterminate all the brutes!'30 The Accident shows the lingering of these assumptions, and the reference to Kurtz gives a specific racial and colonial context to the 'hate' that the dying Saxl passes judgment on and prophesizes. The racial hatred of modern European colonialism that contributed to the Nazi genocide, the racial hatred for which The Accident indicts American society, will dominate the new nuclear age. The character Thiel is saddened by the supplementation of anticommunist hysteria with the language of racism: 'Everybody is beginning to fear the Russians all over again [...] half mysterious Orientals on top of everything. ${ }^{\prime 31}$ Scholars have noted that after World War Two one of the mechanisms to help turn the Soviet Union into America's enemy was 're-racialising' Russians as an essentially ruthless people, a message circulated in US schools. ${ }^{32}$ Perhaps Saxl killed himself for helping to usher in this era of hate. The novel argues against the rigidity of race and civilization, positing that those who claim superiority in these terms committed the Holocaust in Europe and developed atomic bombs against America's enemies.

\section{'We See What Kind of Indian You Really Are'33}

The plot of Martin Cruz Smith's Stallion Gate (1986) follows the Native American Joe Peña, a disgraced serviceman transferred to the Manhattan Project and secretly ordered to protect the Project from Jewish corruption. Captain Augustino, who enlists Joe into the security personnel at Los Alamos, seeks to purify the Manhattan Project's racial ingredients. Augustino confides to Joe his fears that the architect of the atom bomb, J. Robert Oppenheimer, is a Soviet agent intent on developing an 'atomic weapon here only so that he can deliver the finished plans to his Soviet friends'. Riddled with conspiracies, in Augustino's mind the twentieth 
century is 'the Century of the Jew' and Oppenheimer is the 'Third Great Jew', following Marx (who overthrew 'traditional authority and religion') and Einstein (who destroyed 'every absolute in the laws of science'). Augustino's anti-Semitism also derives from his hatred of atheism and communism: 'The Russian Revolution was largely led by Jews'. He tells Joe that the global conspiracy 'does not mean that [Jews] haven't suffered. When I hear of the suffering of the Jews under Hitler, I wish I were a Jew myself. You see, in the Century of the Jew they've taken our hearts, when they already had our minds. ${ }^{34}$ Augustino is either denying the Holocaust or - perhaps satirizing the ability of the paranoid mindset to accommodate contradictory items of evidence - believes it was engineered to manufacture sympathy. He orders Joe to accumulate evidence that will incriminate the head of the Manhattan Project. However, Oppenheimer's Jewishness does not match the racial identity Augustino projects onto him. At one point, Oppenheimer changes into all-American 'Western gear: jeans, boots, silver buckle, hat at an angle'. He is religiously cosmopolitan, 'not a very orthodox Jew. He sort of gets around the whole religious issue by going Hindu. ${ }^{\prime 35}$

Joe has geographically and culturally distanced himself from the Pueblo community, endorsing the medical superiority of white American culture and commenting that only a 'fanatic [...] wouldn't use Anglo medicine'. Oppenheimer commends Joe's modern sensibility and hails him as a 'progressive Indian'. Joe does not see himself as wholly 'Indian': 'I've spent half my life away from here. I've got a half-breed brain now. Lost the old natural dignity.'36 Sharp contends that at the novel's beginning, Joe's 'immersion in the black musical culture of Harlem' has led to his 'alienation' and 'rejection of tribal values' ${ }^{37}$ Accordingly, the local Pueblo elders label Joe 'a fake Indian'. They propose that the non-Native-American communities Joe has passed through have erased his racial authenticity: 'He went away an Indian and came back a black man [...] He went into the Army and became a white man. Maybe there's no one there at all any more. ${ }^{38}$

The plot of the novel explores Joe's ethnic personae and as the conspiracy narrative moves towards closure so too does the unresolved question of Joe's identity. Joe feels he is 'not really from' white America or Native America, and as a consequence he serves 'as a go-between' ${ }^{39}$ The novel intimates that Joe's boundary-crossing may not disqualify him as Native American, and neither can the authenticity of the Pueblo elders be taken for granted. Although Joe does not recognize it, he fits the 'traditional trickster figure' of Native American culture, 'constantly crossing boundaries, [having] sexual adventures, [and] frequently involved in some 
sort of scheme that gets him into trouble' ${ }^{40}$ Joe thinks one of the Pueblo elders 'had such a long nose and his hair was so brown, he had to have some French trader or horny Mormon in his background' ${ }^{41}$ Despite (or perhaps because of) this, the elders embrace a traditional, homogeneous Pueblo culture, and seek Joe's help in sabotaging the technology of the Manhattan Project they believe is a threat to that culture. Jaskoski proposes that Stallion Gate plays out a contestation of space between 'Native American thought' and a 'Western - European or Euroamerican - world view', with the former holistic, respectful of the Earth, and finding knowledge through prophesy and storytelling, the latter based on dissection, calculation, exploiting the land as 'inert commodity' and learning through discourses of 'reductive analysis' and 'mathematical' models. ${ }^{42}$ While broadly accurate, Jaskoski's account is itself reductive for eliding those Native Americans in the novel who use United States Army explosives to search for valuable turquoise by blowing holes in the land.

For most of the novel, Joe is suspended between two types of identity. One is traditionally Native American and situated in opposition to white American appropriation of the land. The other is ethnically polyphonic, signified by Joe's friendships and cultural borrowings. The future home of this second identity is the Casa Mañana, the 'only authentic jazz [club] in New Mexico'. Its existing owner, the African-American businessman Pollack, sells it to Joe for half its value, after being racially abused by the white Texans trying to buy it. Pollack, too, has felt American racism: 'he didn't go cross-country in a train because he never wanted to be mistaken for a porter'. Experiencing different forms of racism has bonded these characters in Stallion Gate, and Pollack's parting words suggest that in the postwar Casa Mañana, the racial equality the Allies profess to be fighting for will be realized: 'We'll show the white trash what this war was all about.' The Casa Mañana - 'house of tomorrow' - is at the centre of the future Joe is planning, which Joe plans to share with his love interest Anna Weiss, a Jewish-German mathematician, and Ray Stingo, a 'primitive Sicilian' who accepts a job as maître d' when the Casa Mañana reopens. ${ }^{43}$ The Casa Mañana is a future oasis for the 'geographically and culturally diverse allegiances Joe is trying to establish to thwart'44 the racist hierarchies of American society.

In Joe's relationship with Anna, Stallion Gate plays with the characters' imprecise and contingent racial identities. Neither matches the European colonial context's original terms of whiteness and its Other; Joe is a 'progressive' Indian, and Anna's whiteness was not sufficient to belong officially to the German Volk. The complexity of Joe's racial identity is at its most keen in the representation of his relationship with Anna; the novel 
suggests their sexual liaison is partly due to her perception of his animal primitivism. At an early meeting, 'She looked at Joe's shirt and could have been scrutinizing the gore on a beast that walked on all fours.' Anna raises an explicit colonial subtext when she discusses her fantasies:

[']I thought I might be a female aviator who crash-landed and had to live with someone like Tarzan while the rest of the world searched for me. When I was rescued, they would understand that I had been forced to submit. There may have been wild Indians involved.'

'In any respectable fantasy. ${ }^{\prime 45}$

The transgressiveness of Anna's desire for a racial Other (it is undisclosed how the 'wild Indians' are involved) is recognized in the masquerade of submission; even in her fantasy, she does not publicly reveal her lust, evidencing the taboo on interracial relationships that a teenage Jew in Nazi Germany presumably felt keenly. Joe's dry comment, 'In any respectable fantasy', draws attention to the racial hierarchy implied by narratives of white virgin maidens ravished by non-white men. By licensing the surveillance of non-white men, Anna's fantasy is the official version of sexual encounters in Europe's colonies and America's plantations. ${ }^{46}$

Suspecting Weiss of conspiring with Oppenheimer, Augustino orders Joe to use his 'Indian charm' to extract information from her. Joe reflects that he may be assuming a racist stereotype as he recounts a Native American Creation myth to Anna, since it smacked of noble-red-manseduces-tourist'. Her response fits this clichéd cultural encounter - 'tell us more fascinating Indian experiences' - and while it is not signposted as ironic, it is difficult to imagine the description of Joe 'as dumb as a yearning brute' could have any other tone when published in 1986. The stereotypes do not ring true for these two characters, but they are available for verbal abuse, as when Anna tells Joe she will leave New Mexico after the war and he accuses her of using him in a sexualized colonial adventure: 'I've been some sort of conquest for you. Entertainment. Part of your tour of Indian country.' In context though, this is likely to be read as proof of his love for her, not a valid criticism of her as sexual tourist. The 'noble-redman-seduces-tourist' encounter is a cultural template they do not fit, but cannot discard completely, so powerful is its influence in structuring their perception of gendered contact between races. Anna's comments on Tarzan (and elsewhere King Kong) illustrate the role of the mass media in the prevalence of these racial templates. Their desire for each other overturns the expected racial positions. The stereotype of insatiable non-white men ravishing chaste white women is inverted when they finally have intercourse in a motel room. Anna 'dropped [her shoes and hat] as soon 
as she came in', her jumpsuit lying 'sprawled, empty, across the middle of the floor', evidently thrown away in a moment of uninhibited passion. In contrast, Joe removed his clothes in an orderly manner. 'His uniform lay over a chair.' ${ }^{47}$

Despite the sanctuary of hybridity represented by the Casa Mañana, despite his interracial relationship with Anna, Joe is drawn deeper into the Pueblo elders' war on the atomic bomb and white America. Joe discovers a cow's carcass in a valley near Los Alamos, killed by the 'poisonous isotopes' dumped there. The cow's skin has changed colour, pointing to the pigmentation of those responsible: 'A hide turned white? That was new.' ${ }^{48}$ Stallion Gate asserts the Manhattan Project's whiteness, its Eurocentrism - 'the logical and inevitable culmination of western empirical thought' ${ }^{49}$ The Manhattan Project is represented as a form of cultural arrogance, riddling Native American land with radioactive isotopes, naming the test site 'Trinity', a name taken from Christian European culture (a religious sonnet by John Donne), and erasing the Native American name it already had, Stallion Gate. ${ }^{50}$ Jaskoski sees the depiction of the Trinity site in the novel as a 'giant laboratory', testifying to the Western assumption that the Earth is 'an exploitable source of wealth that can be destroyed for the amusement of the destroyers'. ${ }^{51}$ Oppenheimer declares the atomic bomb to be at the forefront of technological engineering, while the Native American culture immediately outside Los Alamos remains premodern: 'We are the future surrounded by a land and a people that haven't changed in a thousand years.' This contributes to the reserve Joe starts to feel towards the Project. Having served in the Pacific, earlier in the narrative Joe wanted the Project completed: 'build the bomb and end the war'. He comes to see the Manhattan Project as the imposition of white American culture, obliterating the Native American culture around it, and by the novel's end he renounces his own contribution. He tells Oppenheimer, 'This is your bomb, not mine.' Oppenheimer mistakenly believes Joe is complicit with the elders' plot to sabotage the test site, and verbally attacks him. Oppenheimer insists on the mutual exclusivity of the Manhattan Project's modernity and Native America's backwardness. With the Trinity test about to begin, Oppenheimer tells Joe, 'What an incredibly stupid time for you to turn into an Indian.' For Oppenheimer, the eruption of Joe's racial allegiances makes him hostile to the atomic bomb and Oppenheimer will not let the Project 'be endangered by a...tribe'. Because of Oppenheimer's racial abuse, Joe aligns himself with Native America: 'Everyone insisted he was Indian. So, why not?' Joe tries to prevent the test magically, using the Pueblo elders' 'yellow wands', but he is unsuccessful and in the novel's last moments he runs for cover as the clock ticks down 
towards detonation. The novel finishes with Joe silhouetted against the atomic bomb blast, his fate uncertain: 'From the eye of the new sun, a man diving. ${ }^{52}$ Sharp reads Stallion Gate's abrupt ending as precluding Joe's reabsorption back into his Pueblo tribe: 'Though Joe helps preserve his community by ensuring the elders' escape to Mexico, he may be destroyed before his reintegration into his culture is complete. ${ }^{53}$

The ambiguity of Joe's survival embodies the novel's ambivalence towards any single position on the atomic bomb; readers are offered a spectrum of perspectives, from the necessity of using it to end the war against Japan, to the damage it has done to local Native American communities and the ecosystem. The novel withholds final narrative sanction on any one interpretation of the bomb. The ambiguous ending leaves it unclear whether Joe is dead, or whether his future lies in the jazz club, or the culture of his tribal elders. Joe's final actions suggest he has been seduced by renewed racial pride, but by foreclosing knowledge of his life (if he survives) after the Trinity test, a racially and culturally heterogeneous future remains possible. The novel rejects racial identities, showing their fraudulence and complicity with colonial narratives, such as in the descriptions of Joe and Anna's relationship. Alternatively, Stallion Gate promotes Joe's Pueblo allegiances, defined in opposition to the Manhattan Project's destruction of Native American living space. The Project poisons the land of the Pueblo Indians, and in opposition to this racism inherent in the Manhattan Project (also symbolized by Augustino's pronouncements), Joe finally agrees to sabotage the Trinity test. In its (lack of) conclusion, Stallion Gate keeps Joe's identity suspended between these guises of ethnic authenticity and cultural cosmopolitanism.

\section{'The Most Demonic Success of Hitler was His Ability to Hitlerize His Enemies ${ }^{\prime 54}$}

The narrative device driving the plot of Joseph Kanon's novel Los Alamos (1997) is the investigation into the murder of Karl Bruner, a Jewish German working as an intelligence officer on the Manhattan Project. Michael Connolly, from the Office of War Information, is transferred to Los Alamos to uncover Bruner's murderer and any possible security leaks. In the first scene, Bruner's body is found, preparing readers for an investigation into anti-Semitism as discussed in the two previous novels. However, the casual, institutional anti-Semitism featured in The Accident is absent, as is the conspiratorial anti-Semitism exhibited by Captain Augustino. Los Alamos constructs Bruner as a metaphysical victim, a symbol of Jewish victimization throughout history, and bearing that semantic 
burden means that Bruner's physiology is described as the condensed form of his people's essence. Looking at a photograph from Bruner's file, Connolly notes that before the Nazis tortured him, he had 'the pale Jewish face of a hundred other photographs'. For Connolly, Bruner's face is a paradigm for all Jews whose lives have been taken across Europe. Bruner's life is narrated through the language of the Bible: the cycle of violence that consumed his life is 'an endless series of biblical begats', echoing the genealogies in the Old Testament. Bruner's 'spare, clean room' at Los Alamos is interpreted as his attempt to live 'as unobtrusively as possible, wanting to be passed over', a reference to the Jewish slaves spared God's punishment of the Egyptians (Exod. 12:13). Bruner was tortured by the Nazis for being a communist, and then exiled to the Soviet Union; it is suggested his parents have been murdered in Germany for being Jewish. The Russians 'pulled [Bruner's] teeth out, one day at a time'. When Connolly expresses surprise at Soviet anti-Semitism, the fictional JewishGerman scientist Friedrich Eisler scolds Connolly's naivety: 'Do you think it was only the Germans - ${ }^{\prime} .{ }^{55}$ Despite Bruner's murder, Los Alamos seems like a sanctuary compared to Europe.

Connolly attends one of scientist Hans Weber's musical evenings, and finds Weber and Eisler in a bedroom looking over a magazine filled with photographs of the concentration camps. As Bach plays outside, Connolly's 'eyes swam. He darted from picture to picture, trying to make any sense of it, but the world had tilted slightly on its axis':

bodies were heaped in piles, limbs at unnatural angles, mouths wide open to the air. [...] Children. The men at the fence seemed to hang there, as if they needed to hold the wire to remain upright. In another picture, a vast open pit was filled to overflowing with shaved heads and naked bodies. Everyone was dead, even the ones pretending to be alive at the fence.

European cultural treasures have coexisted with this capacity for barbarism: "German music," Eisler said ironically. "Such beautiful music. You must admit, we are an extraordinary people.["] ${ }^{\prime 56}$ Now, that European culture is revealed in new light. Adorno's comment on the status of aesthetic pleasure after the Holocaust is relevant in this context: 'to write lyric poetry after Auschwitz is barbaric'. ${ }^{57}$ The enjoyment of European fine art, such as lyric poetry or the music of Bach, is compromised since both are presented as products of a European culture calling itself civilized as it commits genocide. Civilization is the mocking claim made by European classical music, 'the rasp of the viola tuning' ${ }^{58}$ in the novel, obscene in its obliviousness to barbarism. Weber joins the other musicians, and plays 
with tears running down his cheeks.

As in The Accident, in Kanon's novel Jewish émigré scientists contribute to the Manhattan Project in order to retaliate against Nazism: 'This was our way of fighting. With our slide rules. Our tests. [...] We would build a bomb to kill all the Nazis [...] with the Nazis, anything was permissible. Even the bomb.' Eisler voices a fight to death, making it legitimate to become as authoritarian and fanatical as the enemy in order to eradicate them. But Eisler complicates this scenario by considering himself as German as he is Jewish. For Eisler, America's atomic bomb is a German invention because its conception was a reaction to Germany's plans to build an atomic weapon, and many of the Los Alamos physicists have come from Germany. For Eisler, Germany represents an apocalyptic European sensibility being reborn in America through the USA's conflict against Nazism:

our culture is over. Perhaps it had to end this way - killing ourselves. Very German. The end of the world. But now it is really over [...] Only this bomb is left - our last gift. I wonder what you will do with it. Perhaps you'll become Germans too. Everybody can become monsters now.

Eisler's condemnation of the country he has fled from compels Connolly to change his vision of the Manhattan Project as a cosmopolitan gathering of international personages. Instead, the atomic bomb becomes an exhibit to German national tendencies, here framed as creativity, vision, absolutism and monstrosity: 'Los Alamos had struck [Connolly] as some overgrown international campus, everybody's project, but that seemed irrelevant now. To Eisler, the Americans, the Hungarians, the Italians, the whole polyglot community were simply spectators to some violent national drama. ${ }^{59}$ Eisler's prognosis haunts Los Alamos: the Americans have become 'Germans' in their campaign to defeat the Axis. At Trinity, Connolly adapts the national anthem to register his changing view of America: 'The rockets' red glare, Connolly thought, the bombs bursting - a macabre new version of the song.' Eisler's moral quandary over his role in the Manhattan Project leads him to irradiate himself fatally, announcing 'one of us should feel [the] effect of what we're doing here' ${ }^{60}$ This is a self-imposed judgment for constructing an apocalyptic weapon at Los Alamos, a point of comparison with The Accident.

One reads Los Alamos aligned with Connolly, whose thoughts are often mirrored in the narrative. The web of espionage Connolly is drawn into complicates his national allegiance, and he is sufficiently embedded in the émigré community of physicists to rehearse their contention that the atomic bomb should never be used: 'We'll be the Nazis.' At the test site, 
Connolly senses that it is 'Not just a weapon' but the promise of extinction without the comfort of transcendental faith:

People had ideas about death. Pyramids and indulgences and metaphors for journeys. Connolly saw, looking out at the cloud in the desert, that none of it was true, that all those ideas, everything we thought we knew, were nothing more than stories to rewrite insignificance. This was the real secret. Annihilation. [...] Now we would always be frightened.

The novel expresses the reign of fear that the nuclear arms race would foster, and the democratic compromises to which the US state would be susceptible during the Cold War. The novel concludes with Oppenheimer's musings on the atomic bomb's future. Connolly warns that the American military will appropriate and monopolize the technology, and Oppenheimer's eyes are 'tired and knowing. "Well, we'll see," he said. "I'm going to hope for the best."'61 The optimism of Oppenheimer's statement is discredited by his 'tired and knowing' eyes, reflecting the deceptions and belligerence of the United States military. Retrospectively informed by the Cold War, readers are invited to see Oppenheimer's vocalized hope as misplaced and the legacy of the atom bomb as dubious and uncertain.

The sense that the atomic bomb does not herald a happy ending of American democracy and pluralism recurs as Connolly confronts Daniel Pawlowski, a Jewish-Polish scientist, at the Trinity test site. Connolly tells Daniel about his affair with Emma, Daniel's British wife. The scientist's failure to imbibe Americanness is revealed when Connolly provides him with transport back to Los Alamos and the émigré asks, 'A car. Is that the American custom?' Connolly asks Daniel to give Emma his blessing to leave him. However, Daniel snarls at the closure Connolly and Emma seek to resolve their illicit union, and suggests that like America and its atom bomb, or America and its disparate cultures, some difficulties cannot be reconciled into a neat whole. 'In America, always the happy ending. Better than the truth. And so easy. Even a car and driver [...] But always there's the loose end, you know. Even here. ${ }^{62}$ That 'even here', uttered at the first atomic-bomb test, might specifically target the 'happy ending' of American victory in the Pacific as 'better than the truth' of the terrifying arms race the Trinity test has inaugurated. This scepticism about the national enshrinement of the 'happy ending' and the danger it represents is foreshadowed in another nuclear-themed novel, Helen Clarkson's The Last Day (1959): 'I believe the most dangerous American tradition is the cult of the happy ending. We just can't believe that anything really bad can happen at the end of our story [...] we have absolute faith that everything will 
turn out all right in the end, no matter what we do. ${ }^{63}$

Bruner was murdered because he uncovered a Soviet-sympathetic spy ring at Los Alamos, of which Eisler was a member, and Oppenheimer's disappointment is concentrated in Eisler's failure to observe group allegiance. Oppenheimer reprimands him for Bruner's murder with the plaintive, 'A Jew, Friedrich. A Jew.' ${ }^{64}$ In Los Alamos, the Oppenheimer character's moral authority lends this comment the force of a truth claim, condemning Eisler for his collusion in an act of violence against a Jew. Eisler's complicity seems hypocritical and illogical, and a greater crime as a result. But while this seems to be the meaning of Oppenheimer's words, his condemnation does not seem logical either. Bruner's murder was not anti-Semitic, it was realpolitik. Oppenheimer's words are one example of the way the novel renders the supposed betrayal of ethnic allegiance as morally reprehensible. In the course of the inquiry, an American of halfMexican, half-Irish descent called Kelly is arrested for Bruner's murder. The language of racial physiology that characterized the representation of Bruner in Los Alamos reappears to account for the terrain of Kelly's features, imbibing the cartographic tendencies of imperialism discussed in chapter 3: 'His face was like a map of his mixed ancestry, the copper skin and Aztec slant of his cheekbones set off by the surprising blue of his eyes.' In Los Alamos, racial intermixture is physically proclaimed: 'Behind the bar was a tall Indian woman, clearly of mixed blood, her long Anglo face set off by unexpected high cheek-bones and long braided hair.' The narrative enforces the incongruity of the physiological traces intermingling in these two characters with the words 'surprising' and 'unexpected'. Furthermore, Kelly and the barwoman are depicted as degrading physically. Kelly's arms are 'thin, sinewy', and there 'was no disguising the meanness of his face'; the barwoman's 'breasts, drooping from years of nursing, spilled into a white blouse' ${ }^{65}$ Their bodies' lack of definition points to physical degeneration, and serves as a marker of the dangers posed when racial sovereignty is compromised (the history of these attitudes is briefly discussed in chapter 4).

Los Alamos is significantly different from Stallion Gate and The Accident in this respect. Kelly's and the barwoman's parents were unfaithful to their own race by reproducing with a member of another, and the degraded fate of their offspring testifies to their imprudence. Los Alamos horrifyingly represents the racial genocide of the Holocaust in Europe and repeatedly makes problematic the pretence of European civilization. It unflinchingly and at times poetically confronts the barbarism of atomic bombs. But while the novel is aghast at racism, it endorses the concept of race. Kelly and the barwoman's physical incongruity professes the inappropriateness of inter- 
racial reproduction, although this is a subtle, implicit point. What is less subtle is the way Bruner's death is turned into a symbol of Jewish suffering across time and space, and because the novel stresses that suffering so forcibly the political contingency of racist violence disappears in comparison to the supposed moral imperative of maintaining one's allegiance to one's racial essence. Which is not to say the novel is completely unaware of how his Jewish identity might be contingent: to the Mexican-American woman who discovers his body, Bruner is just another 'Anglo' ${ }^{66}$

\section{Notes}

1. Theodor W. Adorno, Negative Dialectics, transl. E. B. Ashton, Routledge, London (1973), p. 320.

2. Quoted in Boyer, By the Bomb's Early Light, p. 5.

3. Quoted in Boyer, By the Bomb's Early Light, p. 82.

4. Quoted in Boyer, By the Bomb's Early Light, pp. 198-99.

5. Boyer, By the Bomb's Early Light, p. 224.

6. Anon., 'Atomic Age: Manhattan District', Time (20 Aug. 1945), available at http://www.time.com/time/magazine/article/0,9171,797665-2,00.html (last accessed July 2010).

7. Boyer, By the Bomb's Early Light, p. 138.

8. Kinchy, 'African Americans in the Atomic Age', p. 305. For evidence that the workforce on America's atomic bomb project was racially segregated at Oak Ridge, see Cooper, 'The Whiteness of the Bomb', pp. 80, 83; Boyer, By the Bomb's Early Light, p. 198; Kinchy, 'African Americans in the Atomic Age', p. 306.

9. Weart, Nuclear Fear, pp. 410-11.

10. John Hersey, Hiroshima (1946), new chapter, Penguin, Harmondsworth (1986), p. 66.

11. Anon., 'The Bomb', Time (20 Aug. 1945), available at http://www.time. com/time/magazine/article/0,9171,797639,00.html (last accessed July 2010).

12. Dexter Masters, The Accident (1955), Panther, London (1960), p. 30.

13. Masters, The Accident, pp. 26, 88-89, 161, 222.

14. Masters, The Accident, pp. 189-92.

15. Masters, The Accident, pp. 156, $218,243$.

16. Masters, The Accident, pp. 161, 252, 248, 250, 256, 222, 253.

17. Theodor W. Adorno, Minima Moralia: Reflections from Damaged Life (1951), transl. E. F. N. Jephcott, Verso, London (1978), pp. 55-56.

18. Masters, The Accident, p. 142.

19. Audrey Smedley, 'American Anthropological Association Statement on "Race"' (17 May 1998), available at American Anthropological Association, http://www.aaanet.org/stmts/racepp.htm (last accessed August 2010).

20. Masters, The Accident, pp. 144, 33.

21. Masters, The Accident, pp. 145, 173, 40, 111.

22. Hersey, Hiroshima, p. 182. See also p. 66. 
23. Masters, The Accident, pp. 276, 265.

24. DeLoughrey, 'Radiation Ecologies and the Wars of Light', pp. 477-78.

25. Masters, The Accident, p. 275.

26. Masters, The Accident, p. 62.

27. Masters, The Accident, pp. 271-73.

28. Adorno, Minima Moralia, p. 25.

29. Masters, The Accident, p. 311.

30. Joseph Conrad, Heart of Darkness (1899), Penguin, Harmondsworth (1973), pp. 100, 72.

31. Masters, The Accident, p. 275.

32. Preston, 'Protect and Survive', p. 472.

33. Martin Cruz Smith, Stallion Gate (1986), Pan, London (1987), p. 112.

34. Smith, Stallion Gate, pp. 34-35.

35. Smith, Stallion Gate, pp. 130, 111.

36. Smith, Stallion Gate, pp. 90, 130, 163.

37. Sharp, 'The White Man's Bomb', p. 201.

38. Smith, Stallion Gate, p. 139.

39. Smith, Stallion Gate, p. 164.

40. Sharp, 'The White Man's Bomb', p. 198; Jaskoski, ‘Thinking Woman's Children and the Bomb', pp. 161-62.

41. Smith, Stallion Gate, p. 184.

42. Jaskoski, 'Thinking Woman's Children and the Bomb', pp. 162, 165.

43. Smith, Stallion Gate, pp. 170, 257, 171, 120.

44. Sharp, 'The White Man's Bomb', p. 202.

45. Smith, Stallion Gate, pp. 146, 59, 165.

46. Shohat and Stam, Unthinking Eurocentrism, p. 157.

47. Smith, Stallion Gate, pp. 75, 83, 86, 112, $211,145,143$.

48. Smith, Stallion Gate, pp. 57-58.

49. Jaskoski, 'Thinking Woman's Children and the Bomb', p. 160.

50. Smith, Stallion Gate, p. 82.

51. Jaskoski, 'Thinking Woman's Children and the Bomb', pp. 163, 165.

52. Smith, Stallion Gate, pp. 129, 86, 250, 276-78, 287.

53. Sharp, 'The White Man's Bomb', p. 204.

54. Dieter Georgi, 'The Bombings of Hiroshima', Harvard Magazine (Mar.Apr. 1985), p. 64.

55. Joseph Kanon, Los Alamos (1997), Abacus, New York (1998), pp. 3839, 30-32, 376.

56. Kanon, Los Alamos, pp. 146-147, 150.

57. Theodor W. Adorno, 'Commitment' (1965), in Dennis Walder (ed.), Literature in the Modern World: Critical Essays and Documents, Oxford University Press and The Open University, Oxford (1990), p. 95.

58. Kanon, Los Alamos, p. 147.

59. Kanon, Los Alamos, pp. 149-51.

60. Kanon, Los Alamos, pp. 553, 357.

61. Kanon, Los Alamos, pp. 431, 556-57, 566.

62. Kanon, Los Alamos, pp. 559-60. 
63. Helen Clarkson, The Last Day, Dodd Mead, New York (1959), p. 37. 64. Kanon, Los Alamos, p. 390.

65. Kanon, Los Alamos, pp. 218, 272, 221.

66. Kanon, Los Alamos, pp. 2-3. 


\section{7 'The Hindu Bomb': Nuclear Nationalism in}

\section{The Last Jet-Engine Laugh}

In the twenty-first century the connection between religious fundamentalism, nuclear nationalism, and the pauperization of whole populations because of corporate globalization is becoming impossible to ignore.

Arundhati Roy ${ }^{1}$

'I am become death, the shatterer of worlds': these words, taken as J. Robert Oppenheimer's reaction to the Trinity atomic bomb test, have often been repeated in popular culture. ${ }^{2}$ They come from the Bhagavad Gita (which translates as 'Song of God'), a lecture given by Krishna to Arjuna on the battlefield before the start of the Kurukshatra War. The Bhagavad Gita is part of the epic poem the Mahabharata, a central text within the Hindu tradition. ${ }^{3}$ The nuclear weapon programme that India revealed to the world in May 1998 also invoked Hindu history and culture, in order to justify the righteousness of a nuclear-armed India. These claims were made on the basis of a civilizational superiority whose international pre-eminence necessitated and was reciprocated by the possession of nuclear weapons. To begin with Oppenheimer's quotation of a Hindu text is to raise a theme that will recur throughout this chapter: cultural borrowing as a form of aggrandizement. The development of nuclear weapons was claimed by many Hindu nationalists as a national status symbol because the country had acquired the military accoutrements of other major powers, not least its former European colonizers. On 18 May 1974, India detonated a nuclear device underground, ostensibly to exploit the technology's peaceful applicability for mining and excavation. Strobe Talbott, working in the US State Department, recalled a 'normally reserved Indian diplomat' in Washington who was delighted at the test and quoted the Bhagavad Gita as a reminder of Oppenheimer's words in 1945:

If the radiance of a thousand suns

Were to burst at once into the sky 
That would be like the splendour of the Mighty one...

I am become Death

The shatterer of Worlds. ${ }^{4}$

Talbott's recollection has the diplomat continuing: 'You Americans may have expropriated our deity when your scientists broke open this great secret $[\ldots]$ but that did not give you a permanent monopoly on morality or on technology. ${ }^{5}$

This chapter explores how South Asian writers have understood the possession of nuclear weapons - particularly the testing of India's nuclear arsenal in 1998 - as being central to the Hindu nationalism which achieved electoral success during the 1990s and 2000s. My discussion centres on Ruchir Joshi's novel The Last Jet-Engine Laugh (2001), with extended references to the writings of other South Asian novelists and essayists, including Romesh Gunesekera, Arundhati Roy and Vikram Chandra. As their fictional and polemical texts observe, proclaiming nuclear weapons as a way to achieve parity of international importance with former colonizers and other superpowers is inherently problematic. While a nuclear-armed India fulfils Hindu nationalist rhetoric of national autonomy and the privileging of indigenous culture, such nuclear nationalism is predicated on wielding military technology already possessed by the Cold War nuclear powers. Paradoxically, many Hindu nationalists tried to define India's superior identity as distinct from those nuclear powers.

Appropriately enough for this study, the earliest recorded pieces of Indian prose fiction in English were speculative fictions, namely future narratives of revolution against the British. In one of those texts, Soshee Chunder Dutt's 'The Republic of Orissa: A Page from the Annals of the Twentieth Century' (1845), the country Orissa (whose Hindu population is enslaved by the British) successfully rebels against its wily imperial masters. In 'Republic of Orissa', India is then invited to follow the newly independent nation's example, since throwing off the chains of 'slavery' has allowed Orissa 'to occupy its orbit on the grand system of civilization'. ${ }^{6}$ This political will for India to take its rightful place in the uppermost echelon of the world order is the avowed goal of contemporary Hindu nationalism, and although Joshi's novel shares the radical critique of the Raj made by Dutt's speculative fiction, Jet-Engine Laugh is cynical about the quality of freedom after Independence.

The Last Jet-Engine Laugh follows the lives of the Bhatt family from the 1930 s to the 2030s, cross-cutting between historical periods and employing several narrators. The earliest significant event narrated in the novel is the romance between Mahadevkumar (Mahadev) Bhatt and his eventual wife Suman Pathak - both participants in the Independence movement against 
British rule. Their son Paresh, born in 1960, becomes an internationally celebrated photographer, living in India and Europe and marrying a German citizen, Anna Lang. In 1992 their daughter Paramita (Para) is born, and Mahadev passes away. In making references to pivotal events in India's political and military history (such as the War of Bangladeshi Independence in the early 1970s, the Emergency of the mid-1970s when Prime Minister Indira Gandhi suspended democratic rule, the ethnic violence against Muslims that erupted in 1992 and the nuclear tests of 1998), the novel traces the increasing political power of Hindu nationalism and the nuclear brinkmanship it engaged in during the late 1990s. The novel speculates a future for India that assumes the ongoing presence of Hindu nationalism and militarism.

In the 2017 of Jet-Engine Laugh, a BBC World reporter summarizes the actual historical hostilities preceding the publication of the novel in 2001, and projects a series of future wars:

a quick rundown of the last twenty years of conflict in the subcontinent, things that everybody knows - Kashmir, the Kargil mini-war in '99, the 2007 attack by China and Pakistan that left parts of the Indian north-east under Chinese control and half of Kashmir and Punjab under Pakistani occupation ... the terrorist loose-nuke that devastated south Bombay in '12, the maverick return strike on Karachi by one Indian missile commander even though there was no direct proof of Pakistani involvement. ${ }^{7}$

Jet-Engine Laugh projects three future conflicts: a 2007 war between India and allied Pakistani/Chinese forces, limited nuclear hostilities between Pakistan and India in 2012, and a 2017 war launched by India against the combined armies of Pakistan and Saudi Arabia in which Para victoriously commands a squadron of Ishir fighter-bombers. A fourth conflict seems about to begin in the last chapter of the novel, set in 2030 on the Varun Machaan Indian space station. US armed forces on board the spacecraft Reagan use a new weapon known as 'the Carve' to kill the crew of the Varun Machaan and they prepare to occupy the space station. ${ }^{8}$ Para has improbably survived the Carve and attempts a dangerous escape to Earth in the space station's water module, having programmed the Varun Machaan to self-destruct behind her.

The novel presents these conflicts as the logical consequence of the wars fought between India and its neighbours up to 2001, and uses them to dramatize the issues raised by India's nuclear weapon programme and its political function for Hindu nationalism. After providing the historical background for the rise of Hindu nationalism, this chapter will explore 
Joshi's fictional discussion of the damaging psychological fallout of the 1998 tests and how appropriate Hindu nationalism's stress on indigenous ingenuity is for military technology. The key paradox of Hindu nationalism outlined in The Last Jet-Engine Laugh is that an independent India remains reliant on the iconic currency of the Anglophone West, because it wishes to borrow their symbols of power. The humane values on the grounds of which Independence was fought for, namely the Gandhian espousal of non-violence (this is something Marxist critics have contested), have been betrayed by Hindu nationalism's nuclear belligerency. Joshi emphasizes the squandered hopes for peace seeded by the Independence movement.

\section{The Ascendancy of Hindu Nationalism}

The linkage between Hindu nationalism and India's nuclear weapon programme - the 'nuclear nationalism' referred to by Roy - rests upon race, nation, and civilization to give meaning to the ideology of the Hindu Rashtra (nation). In other words, the Hindu nationalism whose political success in the 1990s was manifest in the election victories of the Bharatiya Janata Party (BJP) and the governments they formed was not driven by exclusively religious concerns, and should not be seen as an Indian turn towards specifically religious fundamentalism (although as Roy's terminology indicates this is a debatable issue). As the subtitle of a 2004 essay by Arun R. Swarmy asks, 'What's Religion Got to Do with It?' Hindu nationalism articulates a history of Indian civilization occupying the South Asian subcontinent, a civilization periodically understood as the property of the Aryan race, with that history culminating in the decolonized Indian nation taking its rightful place among the world's nuclear powers as a modern, powerful, confident state.

Modern Hindu nationalism began in the cow-protection movement of the late nineteenth century. It was also a protectionist response to the Christian missionary activity that grew as the nineteenth century progressed. Hindu nationalism was formally institutionalized in an organization founded in 1915, the Hindu Mahasabha, which promoted cow protection and the Hindi language. One of the Mahasabha's leaders was V. D. Savarkar, whose advocating of Hindutva (Hinduness) has repeatedly characterized Hindu nationalism. The quality of Hindutva was not merely religious but ethnic and national, for Savarkar claimed a unique status for India's Hindus. The geographical congruence of the people and their religion - the fact that Hindus still lived on the land that had produced Hinduism - was the strength of Indian Hinduism. Occupying the same place where their mythological pantheon was located, Savarkar argued 
that 'Hindus are the only people who are blessed with these ideal conditions that are at the same time incentive to national solidarity, cohesion, and greatness.' In 1925, the founding of Rashtriya Swayamsevak Sangh (RSS) saw Hindu nationalism take militant form. The RSS was a 'disciplined cadre-based party' organized into uniformed paramilitary cells, which trained youths in physical strength and self-discipline. The RSS was against the partition of India or any sort of conciliation with Muslims, identifying India with Hinduism and claiming that only the Hindu is the 'child of the soil' of India. ${ }^{9}$

Against the sectarianism of the RSS, at the centre of the self-rule movement was the Indian National Congress. The figurehead of the INC was Mohandas Gandhi, who believed that Hinduism led away from religious chauvinism and towards tolerance of all religions. ${ }^{10}$ Gandhi advocated an Indian Independence movement whose primary weapon against the British Empire was non-violence: through principled opposition India would gain its freedom. Withdrawing in 1947, the British Empire partitioned the country into India and West and East Pakistan (the latter now Bangladesh). At least hundreds of thousands of lives were lost and 12.5 million people were displaced in the sectarian violence that erupted as a result of Partition. ${ }^{11}$ Gandhi's plea for reconciliation between religious communities was interpreted as weakness by the RSS and on 30 January 1948 he was killed by Nathuram Godse, a trainee of gang leader Madanlal Pahwa, a member of the RSS. The RSS was banned until 1949 and the Indian political mainstream in the 1950s and 1960s was defined by the secularism of the Congress Party and its leader Jawaharlal Nehru; the influence of an Indian nationalism espousing Hindutva was marginalized in the early decades of independence, partly because of its role in Gandhi's assassination. ${ }^{12}$

In 1966, Nehru's daughter Indira Gandhi became Prime Minister, a position she occupied until March $1977 .{ }^{13}$ In June 1975, amidst strikes, marches, sit-ins and a court ruling of malpractice in relation to her 1971 electoral victory, Indira hung on to power by declaring a state of extraordinary emergency. She announced an election for March 1977, expecting it to return her to power, but she was defeated by a coalition dominated by the Jan Sangh party. Created in 1951, the Jan Sangh's founder members included Atal Bihari Vajpayee and L. K. Advani, both of whom belonged to the RSS. Although Indira returned to power, from 1977 onwards Hindu nationalism grew within India's governmental structures. The Jan Sangh was remade as the BJP, a Hindu nationalist party advocating a Hindu state. ${ }^{14}$ Following the election in February 1998, the BJP took office as part of a coalition government, returning to power in the October 1999 elec- 
tion with a slightly greater number of seats in the Indian parliament: Vajpayee was Prime Minister and Advani the Home Minister. The BJP supported the late-nineteenth-century economic principles of swadeshi (one's own land) - the commitment to buy indigenous goods - while continuing to open the Indian economy up to the global free market. Amongst other examples of extending Hindutva into Indian society, the BJP Minister of Education appointed scholars professing the Hindu nationalist interpretation of Indian history to national academic bodies. The Jan Sangh and BJP belong to the Sangh Parivar, an umbrella of Hindu nationalist organizations that also includes the RSS, the VHP (a cultural and social service organization) and Shiv Sena, a state political party originally founded to oppose migrant workers entering Maharashtra. ${ }^{15}$

The main targets of the BJP have been Muslims, and India's Muslim population has been victimized and subjected to violent attacks since the 1990s. (Christians, too, were subject to such violence. In the year following Vajpayee's assumption of office, over a hundred incidents of attacks on Christians took place in India. In the BJP's terms, Christians were not real Indians. ${ }^{16}$ ) On 6 December 1992, Hindu militants (including VHP activists) murdered 13 Muslims and destroyed the Babri Masjid mosque in Ayodhya, supposedly built on the birthplace of the Hindu deity Lord Ram. Police and state authorities stood aside. The mosque's destruction commenced a series of pogroms against Muslims across India in which thousands of people, almost all Muslims, were murdered; in Pakistan, Hindu communities were subjected to reciprocal violence. ${ }^{17}$ While the BJP and VHP dissociated themselves from the violence, they had previously focused national attention on the mosque in Ayodhya and pronounced that reclaiming the site was vital for 'national honour'. In the autumn of 1990, Advani started a pilgrimage from Gujarat to Ayodhya, collecting bricks for the construction of a Hindu temple on the ground where the mosque stood. Advani posed as Lord Ram and the van he was driven in was decorated like a chariot and draped in the symbols of the RSS (a saffron flag) and the BJP (a lotus flower). His journey garnered extensive national media coverage, and was described by the RSS as a dharmic yuddha (holy war). The people following him chanted, 'The only place for Muslims is the graveyard or Pakistan. ${ }^{18}$

\section{India's 1998 Nuclear Tests}

The construction of Indian nuclear weapons had been an avowed goal of Hindu nationalists since the $1960 \mathrm{~s},{ }^{19}$ a desire stoked by Pakistan's nuclear weapon programme, active since 1983. India tested five nuclear bombs at Pokhran in May 1998, claiming to be responding to Chinese nuclear tests. 
Neither public opinion nor the political leaders in India and Pakistan saw the tests as directed towards any other country than Pakistan. ${ }^{20}$ In 1998 , the BJP headed a coalition government, and the demands of balancing those competing parties made a nuclear weapon programme for India one of the few 'high-profile themes' of Hindu nationalism that had support across the political spectrum. International criticism of the tests only strengthened the BJP's representation of itself as defending India's interests against global forces hampering its modernization. ${ }^{21}$ Further, the nuclear tests 'deflected domestic criticism of its economic liberalization as a "sell-out" to the old imperial powers'. ${ }^{22}$

Pakistan responded by testing its new Ghauri intermediate range missile and conducting nuclear tests on 11 and 13 May 1998. More tests followed in April 1999; by 2002, India had around 60 operational nuclear weapons and Pakistan up to 40. Kashmir had been the site of several wars between the two countries in the 1940s and 1960s, and conflict broke out again in 1999. The Kargil War lasted roughly two months. ${ }^{23}$ Terrorists attacked the Indian parliament on 13 December 2001, which India blamed on Pakistanibased paramilitary organizations fighting against the Indian presence in Kashmir. India mobilized 700,000 troops to the border with Pakistan, going on a 'war footing' that was meaningfully de-escalated in autumn 2002. ${ }^{24}$

The feeling that harnessing nuclear technology was a source of national pride was reflected on a wide scale after the 1998 tests. ${ }^{25}$ Unsurprisingly given Hindu nationalism's stress upon exercises strengthening the male body, the Sangh Parivar's interpretation of the tests as reversing the power relations of colonization was heavily gendered. Balasaheb K. Thackeray, leader of Shiv Sena, cited the nuclear tests as evidence that Indians were 'not eunuchs'. Scholar Mark Juergensmeyer argues that Hindu nationalism should be seen as a compensatory display of hypermasculinity in opposition to British colonialism's perception of Indian men as effeminate. ${ }^{26}$ Prime Minister Vajpayee's words speak for themselves: 'Let the world know we have a very big bomb. ${ }^{27}$ One British newspaper headline after the 11 May 1998 test was 'Explosion of Self-Esteem'. ${ }^{28}$ David Cortright understood India's nuclear nationalism as a facsimile of other nations' aspirations of international status:

The primary motivations for India's decision to go nuclear are nationalist. India sees itself as a great civilization with a rightful role to play in world affairs [...] India has seized upon the bomb as a shortcut to presumed greatness. ${ }^{29}$

Hindu nationalism's embrace of nuclear weapons is further rebuke to the pacifism of Gandhi, who described atomic bombs as the most 'diabolical 
use of science'. ${ }^{30}$ In August 2000, Advani claimed the most important achievement of his administration had been the development of India's nuclear capability, bringing India international 'respect' - markedly similar to the claims made by the VHP activists who destroyed the mosque in Ayodhya. ${ }^{31}$ Where colonial and neocolonial interference had arrested India's journey to international prominence, nuclear weapon acquisition could reclaim their desired status as a superpower.

\section{Imagining the End}

In Jet-Engine Laugh, Paresh photographs the 1998 antinuclear demonstrators and feels the atmosphere of the time sensually: 'I can still taste that Delhi May in my mouth sometimes.' What he remembers above all is the heat: 'April had already been brutal, and early May worse, but local people were convinced that temperatures went up even more after the first blast on the 11th.' The pathetic fallacy of the rise in temperature refers to the heat of the collective emotion. Nuclear destruction is implicated through a photographic record of one of the demonstrators, where 'you can't even see her face properly, she is in silhouette, back almost fully to camera' ${ }^{32}$ The obscuration of human form to a silhouette echoes the outlines of people burnt into the built environment at Hiroshima. The description of this photograph is weighted with the dawning knowledge that India and Pakistan possess sufficient arsenals to wipe out great swathes of the other's population.

The pervasive nature of nuclear weapons that Roy identified, 'bury [ing] themselves like meat hooks deep in the base of our brains', ${ }^{33}$ is also present in Jet-Engine Laugh in relation to the after-effects of the 2012 atomic bombing of Mumbai and Karachi. Afterwards, the destruction is described as perpetrated by a 'Device'. This verbal work, diminishing its awfulness, becomes a psychological defence mechanism for the survivors who lost family and friends. Nuclear weapons have generated an inescapable anxiety - in 2030 the word 'uranium'34 still echoes around Paresh's head. As the 2017 War unfolds on BBC World, Paresh's friend Viral watches the Indian invasion of Pakistan visualized on a map:

The map develops three arrows striped orange, white and green, the northernmost curving from Amritsar towards Peshawar, the one in the middle coming out of the Delhi border area and pointing straight towards Rawalpindi/Islamabad and the southern one curving out of Rajasthan to stop almost over Karachi, which is shown in black, as they tend to do cities decimated by nuclear bombs. 
As the map begins to track southwards, Viral shuts his eyes. He knows what will come next, the other blackened bit, his bit, south Bombay. He has seen it many times now, but it still knifes into him. The peninsula, the southern half blackened out, as if by a censor's random black marker. The caption 'Mumbai' on one side. He opens his eyes and sure enough, there it is, their-Mumbai-his-Bombay, at the bottom of the screen, at the very edge of the theatre of war. ${ }^{35}$

The narrative moves into free indirect discourse to indicate how Hindu nationalism was involved in Mumbai's destruction. The 'their-Mumbaihis-Bombay' reflects that the nuclear exchange was a product of nationalist grandiosity on both sides of the border: Hindu nationalists would rather have the living Bombay of Viral's memories atomized in a standoff with the hated Islamic neighbour than lose face. The city's name was changed (after Shiv Sena's success in the Maharashtra state elections in the mid1990s) because Mumbai was perceived to be more faithful to Hinduism than the foreign name Bombay. It is 'their' Mumbai to Viral because the name better reflects their religious-national cause; the devastated city works in the symbolic economy of Hindu nationalism by evidencing the continuing danger and affront to national dignity posed by Muslims. Surveying the 'modern marketplace of Indian politics' in 2004, Veera Chandhoke stresses the valuable currency of having 'been victimized in history'. The 'self-justifying ideology of the victim' entitles one to perform acts of 'vengeance', ${ }^{36}$ such as the Indian nuclear retaliation in the novel. In this scene, Mumbai is pushed to the edge of the television's map and blackened out (as with the euphemism 'the Device') but the BBC cannot conceal the absence in the physical world where Bombay used to be. The nuclear exchange haunts Viral; he cannot 'censor' his memory of loss.

Given Hindu nationalism's ideological enshrinement of swadeshi, it would seem appropriate to ask how Joshi represents indigenous weapon technology: are the weapons of one's own land an emblem of religious, national and ethnic superiority? In the 2030 narrative set on the space station, Para's quick thinking lays the ground for victory. The space station's indigenousness is a major factor in her survival only because its construction is old-fashioned. When the Carve hit the Varun Machaan, her crewmates were killed but the material used to build the Ops cabin door protected Para: 'Good old stolid Indian technology. If this was a French or Israeli craft, something made with all those new alloys, the Carve would have turned her into soup by now. Thank god for Indian obsolescence' ${ }^{37}$ This quality of swadeshi is double-edged, as moments previously she had been swearing 'Fucking Indian technology' when the same sliding door 
stuck. Admiring his Alessi coffee machine in 2030, Paresh comments, 'the machine has survived well for something that's thirty-two years old'. In other words, the coffee machine is the same age as India's nuclear weapons, and was 'a design marvel in its time - a child's castle made of shining serious steel' ${ }^{\prime 8}$ The Alessi's age invites readers to interpret this description in terms of India's development of nuclear weapons, where technology originating outside India is appropriated by the Indian government. Paresh's words figure the coffee machine as a military installation built to flatter the youthful desire for play, with the innocence of 'child's castle' and the unselfconsciousness of childhood it connotes running into the reality of people getting hurt. With the double meaning of 'steel' as the alloy and as a blade, the final word in the phrase 'shining serious steel' implies the hard and unavoidable repercussion of owning a weapon: someone will get seriously injured, although that weapon remains fascinating, catching the eye with its glister. Even if you are not the one who gets hurt, do not think this is the ultimate solution: Paresh's coffee machine requires repeated servicing and stutters on its way to performing its function.

The concern with the reliability and safety of weapon technology is applied to the ammunition Para uses in 2017. An interviewee on BBC World discusses the depleted uranium bullets used by the Indian Air Force:

It is what the US Air Force and the RAF first used in the Gulf War against Iran [sic] in 1991 and then again in the NATO strikes in the Balkans in the late '90s and early this century. There was a hue and cry at the time, because DU-based bullets and shells supposedly leave radiation and many attributed the 'Gulf War Syndrome' and, later, what was called the 'Kosovo Strain' to their deployment, but there has never been any conclusive proof connecting DU-based munitions to radiation-related diseases [...] the use of DU was discontinued in 2005 in Europe, but by then Britain had sold the technology and a fair amount of actual ammunition to some countries, and India was one of them. ${ }^{39}$

One of the dominant responses to India's 1998 testing of nuclear weapons in the West was horror and moral outrage. A firm protester against those tests, Arundhati Roy also 'balked at the hypocrisy of Western nuclear powers' ${ }^{40}$ This anger at double standards is voiced in the novel by Viral, who cannot stop verbally attacking BBC World's presentation of depleted uranium bullets: 'Fuck you, you holier-than-thou hypocrite scumfucks, he thinks, first you make it, then you sell it, then you point fingers when people use it' ${ }^{41}$ While Joshi is consistent in rebuking the confident belief of nuclear nationalists that such technology is a quick guarantee of national 
power, his novel refuses to adopt the West's paternalist warning that India should not threaten to use weapons that the USA used in the past and seemingly now regretted. That, too, represents a fallacious linear trajectory of national maturation in which the West has already morally rejected the technologies of war being used by India.

\section{Nuclear Nationalism, Ethnic Absolutism and Antagonistic Acculturation}

Thomas Blom Hansen's study of the Sangh Parivar The Saffron Wave: Democracy and Hindu Nationalism (1999) summarizes the importance of completing the journey to nationhood begun in the anticolonial struggle. Despite decolonization, Hindu nationalists are driven by a desire to abandon the location assigned to [India] at the lower steps of the global evolutionary ladder. Through internal cultural purification and moral discipline and awakening' India's modernity and sovereignty will be recognized, and the country will take its place as a 'respected member' of 'that elusive global "comity of nations"'.42 The 1998 nuclear weapon tests operate in this context as a confirmatory seal on India's insertion into the global community at a level appropriate for a nation of its history, culture and contribution to knowledge. Homi Jehangir Bhabha, leader of India's atomic energy programme earlier in the century, saw (with qualification) 'all humanity within a single trajectory of progress' and wanted to elevate India within that trajectory. ${ }^{43}$ The very assumption that India's rightful position in international affairs is re-established when it slots itself into a linear narrative of progress established by pre-existing superpowers implicitly confirms the righteousness of the developmental model proposed by the Western capitalist democracies. ${ }^{44}$ It is particularly ironic that the Hindu nationalists hailed the 1998 nuclear tests as the seminal moment of national pride. Roy ironically applauds the USA, 'Thank you for showing us the way.' Far from confirming the end of India's colonial and neocolonial dependence, India has shackled itself in a costly subjugation to the responsibilities of nuclear weapons, which are 'are the ultimate colonizer. Whiter than any white man who ever lived. The very heart of whiteness. ${ }^{45}$

This paradox is finely reflected in Romesh Gunesekera's novel The Sandglass, wherein the enrichment of Sri Lanka's international respect is mooted as the corollary to acquiring nuclear weapons. Published in 1998, it is most likely that the reference to nuclear technology in the novel is not a response to that year's nuclear tests but a general allusion to the intricate cycles of indebtedness that the technology entails. The novel, which is largely spoken through remembered narratives, recounts the twentieth-century 
history of two Sri Lankan families. It focuses on the financial competition between the heads of two families, Jason Ducal and Esra Vatunas, and follows the lives of those who outlive them, especially Jason's wife Pearl, his son Prins (who narrates much of the novel) and his friend Chip (the frame narrator). In order to be recognized as a community leader, Esra Vatunas gains the allegiances of two Members of Parliament, Pucksy Mendis and Fosil Gunasena. Their support for Esra is ensured because of the embarrassing secret he holds over them: both politicians missed an important meeting because they were drunk and involved in a sensitive discussion at Esra's home. At that meeting Mendis and Gunasena were introduced to Alexis, an investor in arms manufacture from Zurich. Alexis enchants the politicians by prophesying a lucrative future for Sri Lanka in which the 'surplus labour' of the coastal strip is utilized in military industries:

\begin{abstract}
Alexis's vision [was] of rearming the ceremonial troops of the nation, and vitalizing the burgeoning population of the south through rapid industrial growth in munitions manufacturing. 'All financed through soft loans,' he had said sotto voce. 'Let the Americans play with free milk powder, but you people need to grow up now. They'll never give you atomic power until you show you can fight like a Corregidor [an island in the Philippines, the site of fierce combat during World War Two] veteran. ${ }^{46}$
\end{abstract}

Alexis chides the immaturity of Sri Lanka for being satisfied with diversions such as US food aid. He suggests national adulthood is achievable with a robust military-industrial complex, with 'atomic power' representing the crowning symbol of Sri Lankan statehood, standing at the telos of the journey of militarization. In a modulation of the symbolism of nuclear weapons, here 'atomic power' (rather like the weapons for the ceremonial troops beginning this miniature vision) is a badge of pride awarded to those countries whose military strength compels international recognition.

While the novel does not develop this vision further, it is significant that it is suggested by a European who sees the Sri Lankan economy as an opportunity for investment, a character whose nationality stands as shorthand for the profits to be made from quasi-legal financial activities (the untraceable Swiss bank accounts of innumerable cultural references). These prompts place the parentheses of doubt around Alexis's picture of national pride. The Sandglass suggests the capitalist West signified as 'the Americans' will be the most rewarded beneficiary of any South Asian armaments programme. By advancing the money, Western financiers would 
reap the economic windfall, and military autonomy would coexist with the compromised sovereignty of interest payments. The international respect accompanying 'atomic power' would be undertaken on Western terms, and even this vision of armaments manufacture is a foreign import, introduced into the heads of Colombo's politicians by the investor from Zurich.

In Jet-Engine Laugh's 2017 War, India's victorious strike against the Pakistani and Saudi Arabian armed forces is supported by China because 'that is where the real Chinese/Japanese economic interests lie' ${ }^{47}$ Joshi's novel closely allies the growing interdependency of the global and Indian economies, implying another paradox of the Hindu nationalists: their claim to be committed to swadeshi was advanced alongside a privatization regime inviting multinational corporations to invest in India and siphon its wealth outwards. Roy lists the components of the national infrastructure that the BJP want to privatize: 'water, electricity, oil, coal, steel, health, education, and telecommunications'. She attacks the 'Disinvestment Minister' for his collusion. Roy's thesis is that the most powerful recruiting agents for the RSS are the ramifications of globalization, poverty, frustration and chaos:

The two arms of the Indian government have evolved the perfect pincer action. While one arm is busy selling India off in chunks, the other, to divert attention, is orchestrating a howling, baying chorus of Hindu nationalism and religious fascism. It is conducting nuclear tests, rewriting history books, burning churches, and demolishing mosques. ${ }^{48}$

This solicitation of global capital has left India more, not less, dependent on the richest nations of the world. In Joshi's novel, Paresh observes that the Koji Refrigerator Company is the main sponsor of the 2030 Puja: Japanese capital helps India celebrate its religious festivals. Paresh reflects, 'They like to remind everyone of basic allegiances, our friends from Little Nippon.' The double-edged word 'friend' suggests that one friend in this relationship has the economic power to remind the other of its allegiances, and the promotional slogan indicates that Japanese capital and Indian indigenousness both bow to American English as the international language of trade: 'Have a cool Puja, have a Koji Puja.'49

The relationship between making money and the ideological agenda of Hindu nationalism is a major theme of Vikram Chandra's novel Sacred Games (2006). Largely set in Mumbai, the novel follows the life and suicide of Ganesh Gaitonde, an infamous gangster leading a vast criminal family. Gaitonde's thugs are occasionally hired by the Hindu nationalist politician Bipin Bhonsle to attack and intimidate Muslim families. Bhonsle is a 
Rakshak, a reference to the Hindu nation for whom he alleges to speak, and the Rakshaks 'believed in a golden past, and blood and soil', but despite being a Hindu, Gaitonde 'didn't care for any of those things, not where business was concerned' ${ }^{50}$ The novel forms a circuit linking Hindu nationalism, criminality and commerce, following the example of Salman Rushdie in The Moor's Last Sigh (1995), whose character Mainduck is a Hindu nationalist leader and a boss in Mumbai's criminal underworld. Prefiguring the language Chandra places in the mouths of the Rakshaks, in Rushdie's novel Mainduck 'spoke of a golden age "before the invasions" when good Hindu men and women could roam free', and his stance is antiimmigration, anti-union 'and in favour of wealth'. ${ }^{51}$

In the early stages of Sacred Games, Gaitonde has no intention of disrupting profitable illegal activities to pursue an agenda of ethnic violence, even after the destruction of Babri Masjid. Having 'always regarded the would-be attackers of the mosque and its defenders as equal fools', Gaitonde is reluctant to join the subsequent rioting. His Hinduism is questioned by his subordinates, but his acquisitive allegiances are unshaken: 'So, inevitably, here it was: us or them. Was I us or them? "I'm with the money," I said. "And there's no profit in this." ${ }^{52}$ His main rival is the Muslim gangster Suleiman Isa, but like Gaitonde he does not let religion interfere with business, and he employs Hindus just as Gaitonde employs Muslims. Bhonsle offers to pay Gaitonde to eradicate vulnerable Muslim squatter communities in Mumbai. The land they live on 'belongs to an associate' of Bhonsle's who can develop it for profit. This business arrangement is also an opportunity for Gaitonde to bring his unclear religious allegiances up to the standard of his fiscal imperatives. Gaitonde reflects, 'we were all satisfied, me, the boys, Bipin Bhonsle'. Undertaken for profit, Gaitonde's actions are publicly perceived to seal his ethnic purity. His wife reports, 'Yesterday they were saying, now finally he's showing his true strength. Now we know he's a true Hindu leader.' Having adopted the role of a Hindu gang leader, he finds that it defines him. He strives to fulfil it, killing Muslims in his own crew and feeling 'real' after accepting his Hindu identity. ${ }^{53}$ Gaitonde's Hindutva was bought and paid for by Bhonsle but it assumes the appearance of reality by the actions Gaitonde takes to fit the part (the physical transformations that Indian film stars undergo is a major theme of the novel). Gaitonde's rise to power in the underworld mirrors the political ascendancy of Hindu nationalism, suggesting that violence and illegality shadow the activities of nationalist politicians who are verbally committed to eradicating corruption. When Gaitonde raises this with Bhonsle, he has the effortless retort of the career politician: 'you have to get dirty to do any cleaning [...] Once we are in 
power, it will all be different. We will change everything. ${ }^{.54}$

Like Joshi's novel, Sacred Games warns its readers of the dangers India's nuclear weapon programme represents. While the politician Bhonsle's rhetoric is useful for gaining and preserving power, it is also available to ideologues for whom the threat posed by Islam and Pakistan is so great that nuclear war in South Asia appears the only solution. Through Bhonsle, Gaitonde agrees to regularly smuggle arms into India for cadres he later learns report to Swami Shridhar Shukla, a Hindu guru who supports the nationalist cause. Some of those guns smuggled into the country arrive in the hands of 'an underground Hindu organization called Kalki Sena' which is 'getting ready for a war'. After this war 'there will be a perfect nation, run according to ancient Hindu principles'.$^{55}$ Shukla becomes Gaitonde's guru: when the gangster raises the idea that 'People who are truly spiritually advanced are peaceful' he is mocked by Shukla, who retorts, 'Life feeds on life' and 'the beginning of life is violence'. Rejecting Gandhi's peaceful Hinduism, Gaitonde is taught 'non-violence never brought peace'. Peace must be fought for, and what India needs (in language reminiscent of muscular Hinduism) is 'political will', 'the right structure' and 'discipline'. ${ }^{56}$ Shukla draws Gaitonde's attention to the figures of Hindu mythology who took up violence, particularly the moment when Krishna counselled Arjuna on the battlefield - an incident Oppenheimer would have needed little reminder of, and a premonition of the nuclear war the guru believes necessary for spiritual development. Gaitonde realizes his men have unknowingly carried the components of a nuclear weapon into India. Shukla's labyrinthine operation includes an ersatz Islamist militant group, the Hizbuddeen (Army of the Final Day), whose literature warns of a great fire starting in Mumbai, spreading and killing unbelievers. ${ }^{57}$ This organization is funded by the Pakistani government and will claim responsibility for the detonation of the guru's nuclear device in Mumbai, theoretically leading to India's retaliation and nuclear war between the two countries. In the guru's logic the world must be destroyed before it can be reborn. ${ }^{58}$ As a commentary on India and Pakistan's nuclear nationalism, Sacred Games is not subtle: in the novel, despite their professed religious difference, both countries are in thrall to the same self-destructive competition. Hindu and Muslim militants literally serve the same master. They share a demented fealty to purity that is genocidal and wears irrationality in the clothes of reason, just as Shukla easily dominates Gaitonde in their debates about the righteousness of annihilation.

An obsession with ethnic purity is not only an Indian disease and JetEngine Laugh understands India's BJP government at the end of the twentieth century as a phenomenon related to the rise of ethnic absolutism 
across the world. Para's journey from child of a cosmopolitan GermanIndian couple living in Paris to a celebrated warrior battling against India's enemies is sympathetically portrayed in the novel; symbolically mapping on to India's nuclear militancy, it is the hostility and ethnic absolutism of Europe that compels Para (and to less militant degree, Paresh) to see herself as Indian. Werner Sollors uses Georges Devereux's term 'antagonistic acculturation' to signify the entrenchment of an ethnic identity that takes place 'through a process of - frequently more than justified - resistance'..$^{59}$ Antagonistic acculturation is the construction of an ethnic identity that takes place when one group sees itself in distinction to a proximate ethnic group whose activities jeopardize the existence of the resistant group, possibly through physical coercion, legal disavowal or cultural encroachment. Jet-Engine Laugh indicts Europe for paranoia over security that parallels Hindu nationalism's stress on purity. At the turn of the century, Europe is marking the borders of who belongs and who does not, and like Hindu nationalism the lines drawn are ethnic and religious. As Sollors notes of antagonistic acculturation, 'in an ethnic confrontation, means and ends may be adopted from the opponent'. ${ }^{60}$

Paresh returns to India in 1998 'in protest against the new European immigration policies' designed to exclude further those considered foreigners. In its interpretation of the French coast, the novel implies the difficulties which immigrants face: the sea 'continues to negotiate its arrival against the rocks below, like refugee families at a train terminus'. In this symbolism, the brutalizing experience of seeking refuge culminates not in sanctuary, but the careful act of avoiding destruction against hostile forces arrayed against one's entry. In Jet-Engine Laugh, the policies that compel Paresh to leave Paris are popularly known as the "Fortress Europa" regulations', ${ }^{61}$ drawing on the derogatory use of the term 'Fortress Europe'. When used in this way, the phrase 'Fortress Europe' refers to a white Christian Europe seeking to buttress its identity by expelling elements deemed to be threatening and maintaining rigid border controls. Anne McClintock asks 'whether the emergence of Fortress Europe in 1992 may not signal the emergence of a new empire, as yet uncertain about the frontiers of its boundaries and global reach'. ${ }^{62}$ Talking of the Berlin Wall in the 1980s, Paresh's friend Kalikaku predicts the rise of barriers against migrants: 'today this is looking like it is torn down, but tomorrow it will reappear somewhere. From inside their Berlin they will put it outside ... all around Europe. ${ }^{63}$ Kalikaku believes that the end of a divided Germany will mean Europe divided from the rest of the world. In other words, for Kalikaku once the European continent is no longer separated into East and West and starts to see itself as a coherent whole it will soon exclude those who 
do not belong to that geographical unity.

Paresh ends his residence in Europe because the privileges afforded to him as a recognized arts practitioner are losing ground to the pejorative associations that European security services attribute to his skin colour. What appears to be the seminal incident in Paresh's decision to leave Europe is when he is driving in France with his daughter, and their vehicle is stopped at gunpoint by gendarmes who suspect him of being a criminal called Yousouf Ali. When they realize the mistake, they check Paresh's identification papers and tell Para to get into the back of the car:

'You don't need so many guns to tell me to move my child to the back seat. You scared her.'

$[\ldots]$

'Zees is a war. You ahre luucki we don't shoot you. We don't shoot becoz we see ze girl. Vas-y.'

Joshi's novel was completed before the events of 11 September 2001: already the apparent threat posed by Muslim Algerians (the text suggests) is figured as a 'war' between white Christian Europe and its enemies. The French authorities assume Paresh is an enemy of France, and they declare they would have shot him unthinkingly if Para had not been present. Rather than life being a right, the authorities think Paresh should be thankful for being permitted to retain it. Paresh drives on, and in the novel's last line the sun shines through the trees lining the road and 'Light and shadow drum across the car. ${ }^{64}$ Symbolically, Paresh and Para are living through a period of rapidly oscillating Manichean positions in which they are forced to choose sides. We know by this stage in the novel that Para's allegiances will fall in line with Hindu nationalism. Because Paresh chooses that day to inform Para about the purchase of a new coffee machine, readers can surmise it is 1998, and the nuclear nationalist context looms again. Indeed, the nuclear nationalism of the BJP - the belief their country's sovereignty can only be protected if they adopt the murderous violence of their enemies - is more legible after Paresh and Para's treatment. In the parallel that Jet-Engine Laugh sets up, India's nuclear nationalism is the logical repercussion - on the national level - of the enforced racial worthlessness of non-whites invoked by the security policies of Europe.

Working against this moment when Paresh and Para are forced to choose between India and Europe, the criss-crossing of cultural dialogue and people elsewhere in the novel confounds the homogeneity that Hindu nationalism or 'Fortress Europe' seeks to impose. The narrative suggests Paresh has spent most of his life suspended in planes between Europe and India, which implies the difficulties of slotting oneself into a compart- 
mentalized ethnic camp when one's identity refuses to fit neatly. As Para says with childhood's eyes, 'Pappa's not being an Indian today, he's being...European.' Jet-Engine Laugh questions the national pedigree of the Indian war machine with its references to Para's mixed parentage. Her battle-call is enunciated in a 'slightly German-tinted' ${ }^{\prime 5}$ manner, appropriate for Para's European background on her mother's side but rather discordant in the context of an India defending itself against foreign invasion. One way that Jet-Engine Laugh reminds us of ethnic absolutism's illusoriness is via a malapropism made by Para's mother, Anna Lang. In a letter to Paresh, Anna uses the word 'complexion' when she meant 'complexity'. Bringing these words together invites the reader to reflect on how skin colour is not the outward sign of internal racial essence, but something much more tangled. Paresh reuses Anna's displacement of vocabulary to signify he can see the nuances and intricacy of Para's decision: 'As I looked at my daughter's complexions, things clung on to the cliff edge of my tongue. ${ }^{66} \mathrm{He}$ can see in her 'complexions' that she belongs to more than one epidermically marked racial group, which adds to the complexity of her decision.

Para's embrace of the Hindu nationalist cause emblematizes a common sensibility voiced by the novel's characters: India has squandered the peaceful future for which the non-violent Independence movement worked. In June 2002, Arundhati Roy wrote that 'non-violent resistance' was India's 'greatest gift to the world', but it struggles to survive in an intolerant twenty-first-century India. ${ }^{67}$ Paresh's mother tells him 'the non-violent freedom struggle [had] brought us Independence' and his father Mahadev retorts, 'The Independence to fight amongst ourselves.' In other words, British rule was replaced by interethnic division. Mahadev is pained by the need and effort of making sense of post-Independence India's slide away from Gandhian tolerance; towards the end of the novel, prone on his deathbed, Mahadev asks Paresh to explain to the newborn Para 'the difference between Independence and Freedom. The two are not the same. And one needs both.' Coming shortly after Para's birth, readers are able to date this deathbed scene as a night in 1992, the year in which the mosque at Ayodhya was destroyed and pogroms occurred across India. In terms of Para's absorption into the ideology and military edifice of Hindu nationalism, it seems appropriate she is born at this moment of sectarian violence. Mahadev, as a representative of the secular and inclusive India that the Independence movement fought for in the 1930s, is passing out of this world and the forces of the Jan Sangh are throwing a 'grand nationwide farewell party'. With dark humour, Mahadev calls the fighting in the streets of Calcutta a 'party' - the rioting is the opposite of a joyous celebration. 
Jet-Engine Laugh combines dramatic tension and natal imagery to arrest the reader's attention and direct it towards the monumental shifts taking place in Indian society. The mob gets closer to Mahadev's residence: 'an aural fever coursing through the dark body of the city. The heat of the sound now closer, [...] too close to the house. The roar developing a shape Alllaaaaaaaaaaaaaaaaaaaaaaaaah Ho Akbar! Allaaaaaaaaaaaah Ho Akbar!' Calcutta is personified as a heaving body, a heaving body producing a 'shape' born out of the screams of the riots. The India Para will grow up in is experiencing its birth pangs. Anna comforts Paresh and once more her malapropism is telling: 'You have to rip yourself together [...] This is just nothing but the beginning. ${ }^{68}$ Again, the significance of these pogroms as the opening of a new era is verbalized and expressed by colliding ideas, in this case the actions of pulling together and tearing apart. By targeting (primarily) Muslims as internal forces of disorder, the Hindu nationalists profess to bring harmony to India. They will ensure the nation's coherence by stressing its disunity - in order to purify those heterogeneous elements.

The forces of Hindu nationalism manifested in 1992 had their political corollary in the BJP-led government that came to power in India in 1998. For the BJP and their umbrella of allies, the desired consequence of the 1998 nuclear weapon tests was parity with the world's pre-eminent nations. Nuclear weapons were celebrated as the seal on India's journey from colonial oppression to self-determination: never again could the country be subjugated as it was during the Raj or the Mughal rule. Earlier nuclear powers paraded nuclear weapons for national pride and political leverage, and India followed their lead. Significantly, Hinduism provided the glue to weld an ethnic group to this version of nationalism, because nuclear weapons could be presented as the renaissance of an ancient civilization finally being modernized. Oppenheimer's appropriation of the Mahabharata is re-appropriated: Hindu nationalists argued that India deserves nuclear weapons more than any other country because the bomb' is prophesied in the Vedas and therefore belongs to its religious tradition. ${ }^{69}$ Roy retorts this is a matter of perspective: 'if you look hard enough, you'll find Coke in the Vedas too. That's the great thing about all religious texts. You can find anything you want in them - as long as you know what you're looking for. ${ }^{\prime 70}$ As the novelists and essayists discussed in this chapter suggest, Hindu nationalism can claim nuclear weapons as the culmination of their unique project of religious and ethnic respect in the world but they cannot erase the fact they have already been used by Western nations and former colonizers as remarkably similar signs of international eminence - somewhat qualifying the profession of uniqueness. 


\section{Notes}

The main title of this chapter is a quotation from Chidanand Rajghatta, 'The Hindu Bomb', The Indian Express (21 May 1998), available at http://www.indianexpress.com/ie/daily/19980521/14150864.html (last accessed April 2011).

1. Arundhati Roy, The Ordinary Person's Guide to Empire, Flamingo, London (2004), p. 8.

2. Oppenheimer's biographer Charles Thorpe questions whether his 'iconic' response actually took place. The first public reference to his quotation of the Bhagavad Gita was on 8 November 1948, gaining greater prominence from the late 1950s onwards, but it was not reported by any journalist before 1948, and neither could Oppenheimer's brother Frank (who witnessed the test with his brother) corroborate the utterance (Charles Thorpe, Oppenheimer: The Tragic Intellect, The University of Chicago Press, Chicago [2006], pp. 161-62).

3. Türkhaya Ataöv, Kashmir and Neighbours: Tale, Terror, Truce, Ashgate, Aldershot (2001), p. 30 n. 54.

4. Quoted in Strobe Talbott, Engaging India: Diplomacy, Democracy, and the Bomb, Brookings Institution Press, Washington, DC (2004), p. 14.

5. Talbott, Engaging India, p. 14.

6. Soshee Chunder Dutt, 'The Republic of Orissa: A Page from the Annals of the Twentieth Century' (1845), in idem, Bengaliana: A Dish of Rice and Curry, and Other Indigestible Ingredients, Thacker, Spink and Company, Calcutta (1885), p. 356, quoted in Priyamvada Gopal, The Indian English Novel: Nation, History, and Narration, Oxford University Press, Oxford (2009), pp. 20-21.

7. Ruchir Joshi, The Last Jet-Engine Laugh (2001), Flamingo, London (2002), p. 234.

8. Joshi, The Last Jet-Engine Laugh, p. 346.

9. Barbara D. Metcalf and Thomas R. Metcalf, A Concise History of India, Cambridge University Press, Cambridge (2002), pp. 224-25; Ataöv, Kashmir and Neighbours, p. 83.

10. Ataöv, Kashmir and Neighbours, p. 81.

11. Metcalf and Metcalf, A Concise History of India, pp. 218-19.

12. Rob Johnson, A Region in Turmoil: South Asian Conflicts since 1947, Reaktion Books, London (2005), pp. 23-24; Metcalf and Metcalf, A Concise History of India, p. 229; Arun R. Swarmy, 'Ideology, Organization and Electoral Strategy of Hindu Nationalism: What's Religion Got to Do with It?', in Satu P. Limaye, Mohan Malik and Robert G. Wirsing (eds), Religious Radicalism and Security in South Asia, Asia-Pacific Center for Security Studies, Honolulu (2004), p. 75.

13. Johnson, A Region in Turmoil, pp. 29, 105.

14. Thomas Blom Hansen, The Saffron Wave: Democracy and Hindu Nationalism, Princeton University Press, Princeton (1999), pp. 84-85, 167-69.

15. Metcalf and Metcalf, A Concise History of India, pp. 285-89, 293, 276-77.

16. Stuart Corbridge and John Harris, Reinventing India: Liberalization, Hindu Nationalism and Popular Democracy, Polity Press, Cambridge (2000), p. 136; Metcalf and Metcalf, A Concise History of India, p. 285. 
17. Metcalf and Metcalf, A Concise History of India, pp. 261, 279.

18. Hansen, The Saffron Wave, pp. 162-63; Metcalf and Metcalf, A Concise History of India, pp. 271-72.

19. Swarmy, 'Ideology, Organization and Electoral Strategy of Hindu Nationalism', p. 79.

20. Samina Ahmed, David Cortright and Amitabh Mattoo, 'Public Opinion and Nuclear Options for South Asia', Asian Survey, 38.8 (Aug. 1998), pp. 72744.

21. Hansen, The Saffron Wave, pp. 218-19; Piyush Mathur, 'Nuclearism: The Contours of a Political Ecology', Social Text, 19.1 (Spring 2001), p. 4.

22. Metcalf and Metcalf, A Concise History of India, p. 290.

23. Johnson, A Region in Turmoil, pp. 105-109.

24. Rodney W. Jones, 'America's War on Terror: Religious Radicalism and Nuclear Confrontation in South Asia', in Satu P. Limaye, Mohan Malik and Robert G. Wirsing (eds), Religious Radicalism and Security in South Asia, AsiaPacific Center for Security Studies, Honolulu (2004), pp. 294-98.

25. See Ahmed, Cortright and Mattoo, 'Public Opinion and Nuclear Options for South Asia', pp. 727-44; Mathur, 'Nuclearism', p. 16 n. 5.

26. Mark Juergensmeyer, Terror in the Mind of God: The Global Rise of Religious Violence (3rd edn), University of California Press, Berkeley (2003), p. 208. See also Rotter, Hiroshima, pp. 299-300; Mathur, 'Nuclearism', pp. 5-6.

27. Quoted in Johnson, A Region in Turmoil, p. 41.

28. Quoted in Corbridge and Harris, Reinventing India, p. xvi.

29. David Cortright, 'India's Nuclear Challenge', Peacework, 286 (June 1998), pp. 4-5.

30. Quoted in Ataöv, Kashmir and Neighbours, p. 155.

31. Metcalf and Metcalf, A Concise History of India, p. 292.

32. Joshi, The Last Jet-Engine Laugh, pp. 55, 57.

33. Roy, The Algebra of Infinite Justice, p. 11.

34. Joshi, The Last Jet-Engine Laugh, pp. $111,3$.

35. Joshi, The Last Jet-Engine Laugh, p. 230.

36. Neera Chandhoke, 'Security in Times of Hindutva?', in Satu P. Limaye, Mohan Malik and Robert G. Wirsing (eds), Religious Radicalism and Security in South Asia, Asia-Pacific Center for Security Studies, Honolulu (2004), p. 513.

37. Joshi, The Last Jet-Engine Laugh, p. 346.

38. Joshi, The Last Jet-Engine Laugh, pp. 346, 5.

39. Joshi, The Last Jet-Engine Laugh, p. 243.

40. Roy, The Algebra of Infinite Justice, p. 263.

41. Joshi, The Last Jet-Engine Laugh, p. 244.

42. Hansen, The Saffron Wave, p. 234.

43. Itty Abraham, The Making of the Indian Atomic Bomb, Zed Books, London (1998), p. 99. See also p. 29 and Mathur, 'Nuclearism', p. 11.

44. Abraham, The Making of the Indian Atomic Bomb, p. 12.

45. Roy, The Algebra of Infinite Justice, pp. 10-11.

46. Romesh Gunesekera, The Sandglass (1998), Granta, London (1999), pp. 147-48. 
47. Joshi, The Last Jet-Engine Laugh, p. 234.

48. Roy, The Ordinary Person's Guide to Empire, p. 71.

49. Joshi, The Last Jet-Engine Laugh, p. 109.

50. Vikram Chandra, Sacred Games (2006), Faber, London (2007), p. 244.

51. Salman Rushdie, The Moor's Last Sigh (1995), Vintage, New York (1997),

p. 299, quoted in Gopal, The Indian English Novel, p. 132.

52. Chandra, Sacred Games, p. 391.

53. Chandra, Sacred Games, pp. 393-95, 404.

54. Chandra, Sacred Games, p. 244.

55. Chandra, Sacred Games, p. 509.

56. Chandra, Sacred Games, pp. 575-77, 611.

57. Chandra, Sacred Games, p. 556.

58. Chandra, Sacred Games, p. 704.

59. Sollors, 'Ethnicity', p. 289.

60. Sollors, 'Ethnicity', p. 300.

61. Joshi, The Last Jet-Engine Laugh, pp. 61, 369. It is unclear how far the 'Fortress Europa' regulations in the novel are Joshi's invention. In my research I have been unable to find any legislation that I am confident directly corresponds to the novel's representation of European immigration policies.

62. McClintock, 'The Angel of Progress', pp. 87-88.

63. Joshi, The Last Jet-Engine Laugh, p. 322.

64. Joshi, The Last Jet-Engine Laugh, pp. 375-76.

65. Joshi, The Last Jet-Engine Laugh, pp. 62-63, 373, 213.

66. Joshi, The Last Jet-Engine Laugh, pp. 286-87.

67. Roy, The Ordinary Person's Guide to Empire, p. 7.

68. Joshi, The Last Jet-Engine Laugh, pp. 35, 360-66.

69. Abraham, The Making of the Indian Atomic Bomb, pp. 26-28.

70. Roy, The Algebra of Infinite Justice, p. 30. 


\title{
8 Third World Wars and Third-World Wars
}

\author{
The Western sponsors of 'nonproliferation', according to \\ George Perkovitch, seemed to replicate the pattern of colonial \\ domination in their insistence that only those who had already \\ tested nuclear devices ought to possess such things. Third \\ World latecomers [...] were unwelcome in the nuclear club.
}

Andrew J. Rotter ${ }^{1}$

we should be like the Chinese - poor and riding donkeys, but respected and possessing an atom bomb.

Libyan President Muammar Gaddafi²

This final chapter performs the synoptic work expected of a last chapter, looking back to the literary, scientific and political languages used to represent nuclear weapons since 1945 and thinking about how these traditions remain visible in early twenty-first-century attitudes towards nuclear weapon possession. In addition, this chapter analyses how the meaning of these representations can be connected to race, ethnicity, nationhood and civilization. In the following discussion of proliferation, the terrorist use of nuclear weapons and the fictional construction of the Third World as the primal site of World War Three, for one final time we pay attention to the central contention proffered, debated and challenged throughout this book: that nuclear weapons 'belong' to the white Western world. In his history of American non-proliferation policy, Shane J. Maddock observes:

The primary tenets remained consistent from the beginning of the nuclear age - some states could be trusted with nuclear weapons and some could not. An atomic hierarchy emerged, first in the imagination of U.S. policymakers, then in political reality, that mirrored power inequalities in the global system. This nuclear regime positioned Washington at the top, followed by its NATO allies, and, later, Israel, with the postcolonial world consigned to the bottom. An Indian diplomat rightly labelled the system 'nuclear apartheid'. ${ }^{3}$

The nuclear powers' defence of their entitlement to build weapons with nuclear technology is, of course, not solely (or even primarily) motivated by attitudes of national and racial maturity. For example, the hostile response of the United States to the USSR's building of missile launching sites on Cuba was not motivated by resentment at the enhanced political 
leverage that could potentially be exerted by this postcolonial island nation. It was motivated by a national security need, to prevent the Soviet Union from positioning nuclear weapons so close to the US mainland that there would be an unfavourable (for the USA) imbalance in the speed of the superpowers' nuclear strike capacity. Nonetheless, the language sometimes used in response to this changing geopolitical situation could be expressive of the kinds of hierarchies and prejudices the present study has taken as its subject matter. As Maddock's Nuclear Apartheid (2010) underlines, the imperatives of non-proliferation were more strategic and political than racial or ethnic. Rather than seeing white supremacism as the motivation for nuclear decision-making when race was not the primary factor, I want to draw attention to the way in which linguistic and visual representations of the global distribution of nuclear technology found expression through the register of the West's civilizational superiority and responsibility.

This chapter concentrates on literary, filmic and scientific speculation on Third-World nuclear weapon possession, and with few exceptions the predictions are grim. The speculations are dominated by two fears: the first is that a nuclear bomb will pass into the hands of terrorists who detonate it within a Western city. Shortly before the atomic bomb was invented, physicist Leo Szilard observed that the destructive potential compressed into a relatively small unit made it particularly threatening. His concern was that atomic bombs would make it possible for foreign agents (the future enemy was not stated in March 1945) 'to smuggle in such bombs in peacetime and to carry them by truck into [American] cities'. ${ }^{4}$ This has proven to be a recurrent node of anxiety - and soon after Szilard's fears were published, Chandler Davis wrote the short story 'Nightmare' (1946), in which an atomic bomb is smuggled into New York City.

The second fearful prediction is that an incident in the Third World will become the trigger for World War Three. This is typically attributed to the treacherous use of nuclear weapons by Third-World peoples or by their technological illiteracy in maintaining a nuclear arsenal; both instances construct non-white peoples as less mature, trustworthy and sophisticated than white civilization. Either through incompetence or duplicity, nuclear representations repeatedly envisage a Third-World nuclear incident escalating into total war between the superpowers. In relation to my comments above, superpower resistance to proliferation may be driven by reasonable (or not) rationales that are unconnected to the belief that one race, nation or civilization is more advanced than another, but many representations do reflect those kinds of assumptions. In many of the following texts, ThirdWorld War is separated from a Third World War by a slender hyphen. 


\section{'The Irresponsibles'}

In the late 1950s, trends in the representation of nuclear weapons outside the established nuclear powers coagulated into a recognizable, repeated set of tropes, themes and national characterizations. Nevil Shute's novel On the Beach (1957), in representing Albania as the starting point of World War Three, expresses many attitudes towards non-Western nuclear powers that would resonate through the Cold War. Although Albania is technically a Second-World nation, for various reasons it sat uncertainly within the orbit of Soviet power and the East European communist bloc, and this uncertainty actually increased after 1957. Amongst other factors, very little was known about Albania in the West in the 1950s.

Tracing the impetus for the wider global conflict, readers of On the Beach learn of the Russo-Chinese war that had flared up out of the RussoN.A.T.O. war, that had in turn been born of the Israeli-Arab war, initiated by Albania'. ${ }^{5}$ The essential contributing factor to World War Three is the ready availability of nuclear weapons, both financially and because of the Cold War superpowers' willingness to supply smaller countries with military technology:

the damn things got too cheap. The original uranium bomb only cost about fifty thousand quid towards the end. Every little pipsqueak country like Albania could have a stockpile of them, and every little country that had that thought it could defeat the major countries in a surprise attack. That was the real trouble.

The character John Osborne maintains that the fault lies with the 'pipsqueak' countries: 'don't go blaming the Russians. It wasn't the big countries that set off this thing. It was the little ones, the Irresponsibles. ${ }^{6}$ This becomes a dominant representational trend: the 'little' countries are the 'Irresponsibles', unable to control nuclear weapons maturely, that is, not using them at all. In 1957, the scientist Richard S. Leghorn wrote in the Bulletin of Atomic Scientists that the future of humankind would be jeopardized if movements for Third-World self-determination acquired nuclear weapons:

And in ten years it may not be only 'responsible' nations who have nuclear bombs. The risks of the so-called Nth country problem will be upon us. With the spread of nuclear stockpiles and of atomic know-how through programs for peaceful uses as well as through the arms race of opposing blocs, it is not inconceivable that future Maos, Nassers, or Perons could acquire atomic bombs. What then for the peace of the world? ${ }^{7}$ 
Leghorn adds a further element to this complex of assumptions by connecting peaceful nuclear technology to the production of nuclear weapons. The implication is that civilian nuclear programmes in nonWestern states are to be promoted cautiously, since the technology slides easily into military purposes. In this sense, Leghorn touches on an ethical question posed in On the Beach: should responsibility lie with the 'little pipsqueak' countries who use uranium bombs recklessly or with the superpowers whose geopolitical machinations led to the pipsqueaks acquiring those weapons? In the novel, Commander Dwight Towers leans toward the latter: 'The Russians had been giving the Egyptians aeroplanes for years. So had Britain for that matter, and to Israel, and to Jordan. The big mistake was ever to have given them a long range aeroplane. ${ }^{8}$ In On the Beach these aircraft are used to drop an atomic bomb on Washington, demonstrating the validity of Towers's condemnation of the superpowers' actions (C. W. Sullivan III also sees responsibility shared collectively across the globe in the novel $\left.{ }^{9}\right)$. However, if On the Beach extends responsibility to the United States and the Soviet Union, the narrator returns one's focus to the peoples of Western Asia. As radiation strips Melbourne of human life, Towers perceives that 'the streets' had become 'dirty' and 'littered with paper and spoilt vegetables', reminding him 'of an oriental city in the making'. ${ }^{10}$ Nuclear war has 'orientalized' Melbourne, implying in its effects just which people are to blame for the conflict in the first place.

A similar division of responsibility occurs in Alvin M. Weinberg's December 1958 article 'Prospects in International Science', which critiques the cynicism on display when the superpowers court the Third World with nuclear technology. As with On the Beach, Weinberg's choice of words is laden with the values of colonialism: 'In the old days, when foreigners wished to gain favor with natives they would bear gifts. Nowadays the gifts have taken the form of research reactors or cyclotrons.' Weinberg condemns the nuclear powers for seeking political leverage in the decolonizing world by teaching nuclear proficiency to Third-World representatives. One such example is the International School of Nuclear Science and Engineering, at the Argonne National Laboratory in the United States, training foreign technicians since 1955. Like Towers in On the Beach, Weinberg insists on the culpability of the nuclear powers in the spread of nuclear technology in the Third World. For Weinberg, this is menacing because these 'natives' will convert what was meant for peaceful use into military purposes. ${ }^{11}$

The memory of the Great War and the events of summer 1914 undoubtedly shadowed the belief that the origins of World War Three would be a conflict between smaller countries. The Third Pugwash Conference, concerned with scientific cooperation across national borders and reducing the risk of armed conflict, was held at Kitzbühel and Vienna in September 
1958. The Vienna Declaration produced at the conference articulated the danger posed by any war in the nuclear age:

It is sometimes suggested that localized wars, with limited objectives, might still be fought without catastrophic consequences. History shows, however, that the risk of local conflicts growing into major wars is too great to be acceptable in the age of weapons of mass destruction. ${ }^{12}$

This extract from the conference's 'Vienna Declaration', with its appeal to history, seems to look back to the Great War, and its fear of 'weapons of mass destruction' incorporates both the mechanized killing of the early twentieth century and the bigger weapons of the late twentieth century. Nuclear weapons are 'weapons of mass destruction' that would transform a 'local conflict' into a 'major war' with 'catastrophic consequences'. This early usage of the term 'weapons of mass destruction' suggests that the destructive capabilities of nuclear weapons make them particularly likely to escalate a localized war - the 'mass' in this context refers to magnitude of global proportions.

Against the rhetoric of irresponsibility, a British film at the end of the 1950s argued that 'little pipsqueak' nations may be the most dutiful custodians of weapons of mass destruction. The Mouse That Roared (1959) even proffers the presence of nuclear weapons outside the Cold War power blocs as an effective stimulus for nuclear disarmament. The fictional country in question is Grand Fenwick, a duchy in the French Alps and the smallest nation in Europe, which is paralleled with decolonizing states in the film's fabricated history. Founded in 1430 by the British Roger Fenwick (he 'took a fancy to the neighbourhood and moved in'), Grand Fenwick is experiencing economic difficulties: the 'small but sturdy wine' that is the duchy's sole export has been copied by a Californian vineyard producing a cheap imitation, and the country faces bankruptcy. Running throughout the film is a suspicion of the economic and military power that America wields in the world and the contention that this overbearing presence has distorted the perception of America from inside and outside the nation. Mouse was funded and produced by Carl Foreman, a former Hollywood writer and producer who had been blacklisted for his communist links and moved to Britain in 1952. ${ }^{13}$

The Marshall Plan that resurrected European economies after World War Two is identified by the government of Fenwick as their only hope. Learning from the American-aided reconstruction of West Germany and Japan that 'Americans forgive everything', the state of Fenwick decides to go to war with the United States. The plan is to lose quickly and let Amer- 
ican capital rebuild their economy: 'We declare war on Monday, be defeated by Tuesday, and by Friday will be rehabilitated beyond our wildest dreams.' Unfortunately, when the United States receives Grand Fenwick's declaration of war, the official who reads it dismisses it as a prank. The army of Fenwick arrives in New York with no one to capture them; because of an air-raid drill, the city's population is sheltering underground. The Fenwick army marches into the New York Institute of Advanced Physics, seizes General Snippet, Dr Alfred Kokintz and the 'Q-Bomb' ('infinitely more powerful than the H-Bomb'), and returns to Europe. Travelling back across the Atlantic, the Fenwick army is once more represented as a primitive military force when they fire longbows (their only weapon) at the British flagship vessel Queen Elizabeth. ${ }^{14}$ World attention concentrates on Grand Fenwick, now in possession of the most destructive weapon ever built. Field Marshall Tully, commander of the Fenwick Army, informs the American envoy, 'We'd like your President [...] to try and persuade the United Nations to let the little countries of the world look after the [Q] bomb. We want a general disarmament, and we want this league of little nations to be in charge of the inspection.' And if the 'big nations' do not disarm, Grand Fenwick will 'just have to explode the bomb'. The Duchess of Grand Fenwick adds, 'If there was another war, we'd all be blown up anyway.' Why not risk being destroyed to ensure a world without the threat of nuclear war? The film's closing title 'THE END...we hope' avows the film's allegiance to this vision of the future, disarmament catalyzed by the intervention of a nation outside the power blocs. Shaw notes that the idea of small states providing the moral antidote to the machinations of the nuclear powers was most rubbished in the leftwing press, for whom the acquisition of nuclear weapons was no laughing matter. ${ }^{15}$ Certainly, in proposing that unilateral disarmament could be compelled by a nonaffiliated small state threatening destruction against larger states, The Mouse That Roared reiterates the logic of Mutually Assured Destruction: knowledge that absolute violence would be met with absolute violence compels other nations in the world to behave peacefully. The film's conclusion subscribes to the strategic utility of deterrence. Its relative radicalism lies in the depiction of which nations are deterring others from nuclear weapons, accrediting moral authority to 'little' nations because they are willing to threaten the world with Q-Bomb destruction.

\section{Crisis in the Caribbean}

The threat of World War Three and the dangers posed by 'little' nations were combined in the language and literature surrounding the Cuban 
Missile Crisis of October 1962. The USA and the USSR confronted each other diplomatically when the Soviet Union began to build launching sites on the island of Cuba that were capable of firing nuclear missiles. Eventually, both sides agreed a set of diplomatic solutions and face-saving measures, including the dismantling of the launching sites. This moment in Cold War history is often read as the closest the superpowers came to nuclear conflict. Presumably unintentionally, Marine Corps Commandant David Shoup paraphrased On the Beach when he commented to President Kennedy, 'Does it mean they're [Cuba] getting ready to attack us, that little pipsqueak of a place?'16

An interesting analysis of proliferation can be read across two novels by British writer Ian Fleming, Thunderball (1961) and You Only Live Twice (1964). Both texts are popular espionage thrillers featuring the British secret agent James Bond, and both pit Bond against the criminal mastermind Ernst Blofeld. In Thunderball, Blofeld's organization SPECTRE steals two atomic bombs and holds the USA and UK to ransom for $£ 100$ million. If they do not pay the money in a week, 'a piece of property belonging to the Western Powers [...] will be destroyed. There will be loss of life. If, within 48 hours after this warning, willingness to accept our terms is still not communicated, there will ensue, without further warning, the destruction of a major city. ${ }^{17}$ The response registered by the novel is not horror or even Commandant Shoup's surprise. Bond is blasé, even by the standard set by the character's earlier exploits:

Just what his Service and all the other intelligence services in the world had been expecting to happen. The anonymous little man in the raincoat with the heavy suitcase - or golf bag, if you like. The left luggage office, the parked car, the clump of bushes in a park in the centre of a big town.

As Leo Szilard predicted in 1945, atomic bombs appear to be the most valuable prize in the urban terrorist's toolkit because of the large scale of destruction in proportion to their relatively small size. Even though Blofeld's organization is not the fifth column of another nation, or a religious or political terrorist group, and it has acquired atomic bombs by elaborate theft, Thunderball still uses a vocabulary about proliferation resembling that of other texts in this chapter. Bond's interior monologue continues:

And there was no answer to it. In a few years' time, if the experts were right, there would be even less answer to it. Every tin-pot little nation would be making atomic bombs in their backyards, so to 
speak. Apparently there was no secret now about the things. [...] And this was the first blackmail case. Unless SPECTRE was stopped, the word would get round and soon every criminal scientist with a chemical set and some scrap iron would be doing it. If they couldn't be stopped in time there would be nothing for it but to pay up. ${ }^{18}$

Partly to lend the quest narrative greater significance, the success of Bond's mission is tied to the future status of atomic weapons. If he finds the bombs and thwarts SPECTRE he will deter further nuclear blackmail cases. What he cannot do is avert proliferation, and in this interior monologue Bond mentally recruits the advice of 'the experts' to attest that the capability to build atomic bombs is becoming widely available. Rather than accredit international esteem to their owners, he foresees them becoming common to 'every tin-pot little nation' and his predictions are those of On the Beach, when 'every little pipsqueak country like Albania could have a stockpile' of uranium bombs because 'the damn things got too cheap'.

Blofeld's scheme, codenamed Operation Thunderball by the UK government, is foiled by Bond's intervention, and the stolen bombs are recovered. Bond and Blofeld clash again in Fleming's You Only Live Twice, published after the Cuban Missile Crisis. The criminal mastermind references this event while he crows over the secret agent as a prelude to killing him. As Bond feared in Thunderball, Blofeld avows that had his blackmail plot been successful it would have transformed the balance of nuclear power. But the leader of SPECTRE does not believe it would have encouraged other atomic blackmailers; had his project been completed, Blofeld states it would have had 'a valuable by-product'. Reminding readers of the Cuban Missile Crisis, Blofeld suggests 'in the hands of a Castro' nuclear weapons 'could lead to the wanton extinction of mankind'. SPECTRE's plan was a 'dramatic example' that atomic bombs are 'dangerous toys that might so easily get into the wrong hands'. If only the ransom had been paid, Blofeld hypothesizes, the awareness of the jeopardy the UK and the USA had been in would have compelled them to revise the wisdom of maintaining an arsenal of such weapons. He asks, might 'not the threat of a recurrence of my attempt have led to serious disarmament talks[?]' Blofeld claims to stand for those poorer nations excluded from the nuclear club by lack of wealth. 'Rich boys are playing with rich toys. A poor boy comes along and takes them and offers them back for money.' His moral righteousness draws its strength from this financial inequality, arguing that which countries have nuclear weapons is seemingly controlled by the richest nations, but should they be used they would affect 'the whole world'. For Blofeld, the nuclear powers have arrogated the world's future, and they would destroy 
the Earth if the leaders of 'poor' nations such as Cuba tried to break into their nuclear club. ${ }^{19}$

As a villain mistakenly delivering what he believes is his victory monologue, readers are automatically suspicious of Blofeld and his critique of the nuclear hegemony. Those familiar with this series of novels (and films by this point) would be likely to expect Blofeld's momentary position of power to be rightfully usurped by Bond before the end of the narrative. However, Blofeld (in You Only Live Twice) and Bond (in Thunderball) do share the belief that humankind is at risk should atomic bombs fall into the hands of 'little' or 'poor' nations. Bond is concerned it is inevitable as the technology becomes more available; Blofeld's rhetoric sees someone like Castro acquiring atomic bombs only if he 'takes them' from a nuclear power. His reference to Castro suggests a worldview whereby it was Cuban recklessness and not Soviet brinkmanship that made nuclear war such a treacherous possibility in 1962. Certainly, a rather different interpretation emerges in Robert F. Kennedy's first-hand account 13 Days (1969), in which responsibility for the missile sites in Cuba lies with the Soviet Union. In fact, during the Cuban Missile Crisis President John F. Kennedy referred to Cuba as being 'under foreign domination', with leaders who 'are puppets and agents of an international conspiracy' ${ }^{20}$ Castro is figured by the Kennedy brothers - in the forums of published memoir and public address, at least - as a marionette manipulated by Moscow rather than an errant political actor.

The character of Dikko Henderson in You Only Live Twice, an Australian intelligence agent stationed in Japan, is another advocate for the cultural immaturity of 'little' or 'poor' nations. After telling Bond to 'get it into your head that the Japanese are a separate human species', he voices his opposition to decolonization and concludes with an apocalyptic prediction:

the U.N. are going to reap the father and mother of a whirlwind by quote liberating unquote the colonial peoples. Give 'em a thousand years, yes. But give 'em ten, no. You're only taking away their blowpipes and giving them machine guns. Just you wait for the first one to start crying to high heaven for nuclear fission. Because they must have quote parity unquote with the lousy colonial powers. I'll give you ten years for that to happen, my friend. And when it does, I'll dig myself a deep hole in the ground and sit in it. ${ }^{21}$

In the context of the novel, this is presented as a bigoted, unreasonable position. The character of Dikko seems to be a deliberate parody of the stereotypically chauvinistic 'Aussie' who denigrates Australian aboriginal people and uses homophobic insults. Important for evaluating the veracity 
of Dikko's diatribe, Bond appears to enjoy the Australian's drunken company and humours his politics but does not necessarily agree with them. With his annoying habit of placing 'quote' and 'unquote' around terms he disagrees with, and his antagonistic rhetoric of 'just you wait' and 'my friend', it is difficult to empathize with Dikko. His final image is isolationist and childish, and contrasts against Bond's activity in preventing 'nuclear fission' being used harmfully. Between Blofeld and Dikko, Bond represents a suitably reserved middle position, working to minimize proliferation while resigned to its inevitability, seeing danger in 'every little tin-pot nation' becoming a nuclear power but not the automatic revulsion that Dikko had for formerly colonized peoples or that Blofeld attached to Cuba and other 'poor' nations. Appropriately for a secret agent in Her Majesty's Government, Bond's stance on proliferation is depicted as a very reserved and reasonable form of discrimination.

The year after the Cuban Missile Crisis, Kurt Vonnegut Jr's novel Cat's Cradle (1963) dramatizes nuclear tensions through an apocalyptic weapon called ice-nine. Ice-nine solidifies all water it comes into contact with, and is fatal when ingested, so once introduced to the ocean towards the novel's end it means the extinction of humankind. Two characters take sanctuary in 'a cosy bomb shelter', but death is inevitable: 'Anything that still lived would die soon enough of thirst - or hunger - or rage - or apathy. ${ }^{22}$ Icenine symbolizes nuclear weapons in its destructive power and its fictional heritage, created by Dr Felix Hoenikker, 'one of the so-called "Fathers" of the first atomic bomb'. ${ }^{23}$ In Literary Aftershocks (1994), Stone records its similarities with nuclear weapons and the international situation in 1962, commenting that ice-nine is a doomsday device divided between 'the United States, the Soviet Union, and a small Third World nation [...] And the Third World Caribbean country accomplishes what the Cuban Missile Crisis barely failed to do.' With its 'postcolonial black population', ${ }^{24}$ San Lorenzo stands in for Cuba in Cat's Cradle. It seems that a non-white, ThirdWorld nation that asserts its independence from Western control is a menace to humanity, and its history of dissidence was signalled when it was founded 'in 1786, [when] African Negroes took command of a British slave ship, ran it ashore on San Lorenzo, and proclaimed San Lorenzo an independent nation'. The erratic nature of the former slaves is demonstrated by the emperor who proclaimed San Lorenzo's independence, the 'maniac' Tum-bumwa. ${ }^{25}$

It is reasonable to respond to the assertion that Cat's Cradle circulates fears about the irresponsibility of Third-World nations with the retort that the technology is actually American, and that the novel articulates the apocalyptic consequences of Western science's will to dominate nature. ${ }^{26}$ 
For instance, ice-nine is brought to San Lorenzo by Felix Hoenikker's son Franklin. The island's ruler, Miguel 'Papa' Monzano, is seduced by the access to scientific modernity (and ice-nine) represented by Franklin's pedigree: 'Science - you have science. Science is the strongest thing there is.' Paradoxically, Papa conceives of Franklin's gift of science in the most irrational and superstitious terms, celebrating him as 'a chunk of the old man's [Felix's] magic meat'.$^{27}$ One of Cat's Cradle's most salient features in terms of my argument is the division between science and superstition; on one side, a rational, scientific, technologically advanced white Western nation, on the other, a non-white, Third-World Caribbean people, who are characterized by irrationality, folk wisdom and a rejection of the West's confidence in scientific knowledge. It is not that the latter are demonized in the novel, as the people of San Lorenzo (as opposed to its rulers) are portrayed sympathetically and the novel works hard to invite readers to share their allegiances with San Lorenzans. Rather, non-white peoples are represented as at odds with modernity, a modernity that includes nuclear technology. They are always outside, 'always oppositional to technologically driven chronicles of progress', as Alondra Nelson has written of constructions of blackness in Western culture. ${ }^{28}$ In light of nuclear power's destructivity, Cat's Cradle offers a 'technologically driven chronicle' of catastrophe, and much of the novel's support for the people of San Lorenzo derives precisely from their presumed opposition to Western regimes of knowledge. And yet the nature of the novel's privileging of San Lorenzans reinscribes the primitiveness of black Atlantic populations. The people of San Lorenzo are the 'miserable folk of another race'. Physically, the San Lorenzan men fit the stereotypical Western construction of black peoples as unable to feed themselves ('thin') and endowed with large genitals: the men had 'penes like pendulums on grandfather clocks'. The highly sexualized nature of the San Lorenzans is conveyed through Cat's Cradle's narration, which is delivered by the character John Hoosier, who powerfully desires Papa's daughter, Mona Aamons Monzano. Hoosier's perception of her is infused by her status as racially exotic: 'She was very young and very grave [...] and luminously compassionate and wise. She was as brown as chocolate. Her hair was like golden flax.' The narrative cannot conceive of Mona's beauty without couching it in terms of her mixed race, 'blonde Negro' or 'sublime mongrel Madonna'. Especially problematic is 'mongrel', withholding a degree of humanity from Mona while suggesting part of her attractiveness comes from racial intermixture. 'Every greedy, unreasonable dream I'd ever had about what a woman should be came true in Mona.' ${ }^{29}$

Two potential objections to my position can be made: the first is that 
the novel alerts readers to be sceptical of Hoosier's narration and not to read the narrator's filtering of events as a mimesis of the diegetic world. The second (related) objection is that the narration is ironic, using racist stereotypes and assumptions knowingly and inviting readers to laugh at the ridiculous extremes to which they are taken. There is some credence in the first interjection. In an early book on Vonnegut, Peter J. Reed argues the novel invites readers to see it as untrustworthy from the very first line, 'Call me Jonah. ${ }^{\prime 30}$ This intertextual allusion to Melville's Moby Dick is read as a reminder that everything that unfolds afterwards is fictional, including the narrator. Reed references several incidents in the novel where Vonnegut parodies his earlier work or where words are shown to be distant stand-ins for their referents. ${ }^{31}$ One example relates to Mona's body, conceding the unreality of language use, which is a substitute for, but never gives us, the thing itself: her 'breasts were like pomegranates or what you will, but like nothing so much as a young woman's breasts'.$^{32}$ Or rather, even as this sentence elicits laughter at the ornamental figurations of language, Mona's tangibility cuts through Hoosier's verbiage. Tellingly, the sexualized physicality of the biracial woman has an authenticity strong enough to disrupt the games with figuration that constitute humankind's understanding of itself in Cat's Cradle (the object in the title is another example of the gap between what a thing is and what it is called).

Conceding the first objection may in fact cancel out the second objection. The argument that the level of stereotyping in Cat's Cradle is deliberately excessive and not meant to be a realistic representation is the alibi allowing the novel to offer up these representations without any moral compass. Reed balances up the 'possibilities and limitations' of Cat's Cradle, suggesting that as a consequence of the novel's abandonment of the 'techniques of the representational novel' even when humankind comes to the end of its meaningless lifespan the bleakness of this scenario remains 'unreal' to the reader. Reed positions the novel closer to cynicism than nihilism, on the grounds that the novel offers compassion and love as alleviating the emptiness of existence, but (unlike Vonnegut's earlier novels) this is intimated rather than experienced in a narrative that closes without having registered 'human feeling'. ${ }^{33}$ Writing about the predilection towards the ironic mode amongst certain German intellectuals in the interwar period, Walter Benjamin noted that irony was offered as adequate replacement for the loss of 'love, enthusiasm' and other human, spiritual qualities: 'A know-all irony thinks it has much more in these supposed stereotypes [of lost human feelings] than in the things themselves; it makes a great display of its poverty and turns the yawning emptiness into a celebration. ${ }^{34}$ We might see Cat's Cradle as celebrating the 'poverty' of its 
images of blackness, taking them to the most naked (figurative and literal) extreme. Aware these stereotypes do not have referents in the world beyond the text, Cat's Cradle flaunts their 'yawning emptiness'. One might defend the novel's concatenation of racist images by stating that this excess is intended to draw attention to their status as stereotypical depictions of blackness, in order to neutralize the criticism they are being used in the novel in a racist manner - it already 'knows'. For Benjamin, this 'knowall irony' is the enemy because it is a substitute for sincere debate. Beyond offering a repertoire of conventions that the reader will probably concur is racist, Cat's Cradle appears to be recycling said repertoire without adding anything further as a moral statement. This flattening of meaning makes it difficult to read the novel's depiction of blackness as satirical. If the novel knowingly plunges into the zero gravity of representations severed from any world that exists beyond those representations, where is the referential solid ground needed to establish that political satire - mocking a political position or ideology - is taking place? Rather, these stereotypes are polarizing the novel's depiction of rationality, science and modernity along colour lines and marking out separate, racialized modes of being.

Prefiguring the depiction of the San Lorenzans' exteriority to modernity is the character of Lyman Enders Knowles, 'a small and ancient Negro' at the laboratory where Hoenikker worked. This language hints that Knowles is personally venerable as well as being a representative of an 'ancient' race. The narrator provides evidence that 'Knowles was insane' by quoting his speech: 'Hello, fellow anthropoids and lily pads and paddle wheels'.$^{35}$ Knowles's exile from rationality and modernity chimes with the philosophy of Bokonon that peppers the novel. Bokonon is a prophetic figure in Cat's Cradle, a 'Negro' born in Tobago in 1891, who 'enrolled in the London School of Economics and Political Science', fought for the British in the Great War and became 'a follower of Mohandas K. Ghandi' ${ }^{36}$ From the position of the British Empire in 1963, in the midst of decolonization, Bokonon's political allegiance invokes the spectre of non-white colonial subjects (once loyal, as evidenced by their participation in the Great War) now resistant to Western authority. With his history, Bokonon has imbibed a metropolitan education and distorted its values, just as he is now known by a dialect form of 'Johnson', his surname. Bokonon is 'against science', lives in the hills of San Lorenzo and rejects urban modernity: 'what an ugly city every city is!' He is a criminal to Papa's regime, a 'communist' against the capitalist organization of society. A wanted poster depicts him as 'a scrawny old coloured man [...] smoking a cigar. He looked clever and kind and amused. ${ }^{\prime 37}$ This image gestures towards the symbolism of the Cuban Missile Crisis at work in Cat's Cradle, Bokonon toting the 
iconic cigar favoured by Fidel Castro, communist leader of Cuba. Bokonon also suggests the stereotype of the wizened old black man who is the receptacle of folk wisdom and humour. ${ }^{38}$ That Bokonon has become 'insane' ${ }^{39}$ conjures up the figure of the Shakespearean fool, who has lost his or her reason but voices eternal truths. These eternal truths are excerpted in Cat's Cradle from the fictional The Book of Bokonon, a collection of his sayings. Cat's Cradle was written near the start of literary postmodernism, and Bokonon insists knowledge is a pretence humankind is unable to abandon, human history is a record of inhumanity and the future existence of the species is unlikely. ${ }^{40}$ Followers of Bokonon have as their sacred object 'Just man', and Bokonon even employs an auto-critical scepticism of his own pronunciations, refusing to adopt a tone of authority: 'Close this book at once! It is nothing but foma [lies]!' Bokonon's final act, the last words of The Book of Bokonon, is a gesture of defiance against the notion of a deity whose existence would give meaning to human life and human suffering. Bokonon advocates taking one's own life by imbibing ice-nine and proceeding to lie on his 'back, grinning horribly, and thumbing [his] nose at You Know Who'. Gleefully embracing his own meaninglessness, Bokonon confirms himself as an avatar of a postmodern tendency that confounds notions of 'progress' by citing 'the history of human stupidity', ${ }^{41}$ but it is a defeatist postmodern sensibility shading into antimodern reaction.

In Cat's Cradle, the end of the world emanates from an island in the Caribbean, the product of military technology first completed by the United States. The novel's depictions of San Lorenzo and ice-nine are expressions of wider cultural fears surrounding the Cuban Missile Crisis and nuclear weapons. The San Lorenzans are apprehended through stereotypical sexualized racial imagery differentiating them from the white, urban, scientific, capitalist United States in which the first section of the novel is set. Bokonon can be read as: a symbol of black Atlantic populations coming to self-determination as European imperialism is in decline; a communist, cigar-brandishing Castro; or a madman prophet railing against cities, science, notions of rationality, progress and grand narratives, who nonetheless reflects on the limitations of his own philosophizing. Cat's Cradle marshals readers' empathies towards Bokonon and his rebellion, offering in human extinction a firm example of why Bokonon's rejection of detached Western science and his exultation of human spirituality is so valuable. ${ }^{42}$ Yet Bokonon rejects the modernity that produced ice-nine and atomic bombs, embracing exile from modern civilization and finally death rather than critiquing the terms that structured his exclusion. 


\section{The Yellow Peril Revisited}

At least since the Yellow Peril fictions of the nineteenth century, Asian peoples had been represented in Western texts as swarming uncontrollable masses, and after the People's Republic of China's 1964 nuclear tests that representational tradition was observable in the depiction of China's speculated nuclear aggression. Allen Ginsberg's 'Beginning of a Poem of These States' (1965) locates the possibility of nuclear 'Armageddon' in a dispute between two Asian states: 'Chinese armies massed at the borders of India [...] Red Chinese Ultimatum 1 A.M. tomorrow' ${ }^{43}$ The late 1960s and early 1970s saw nuclear anxieties focus on an aggressive, unpredictable China, latecomer to the Nuclear Club. Morris West's novel The Shoes of the Fisherman was first published before the PRC nuclear tests, in 1963. In its speculated near future, China is ravaged by famine and plans to invade Southeast Asia to feed its people: 'The Chinese have gone to Moscow and [...] they want a war now, or they will split the Marxist world down the middle.' As a result, the United States and the Soviet Union are heading reluctantly but inevitably into a 'cataclysmic cosmic war' ${ }^{44}$ In the 1968 film adaptation, produced after China's nuclear tests, the menacing aspect of the Chinese hordes is amplified. Famine-stricken China assembles its armies on the Russian border, and the Soviet Premier is concerned that lack of foreign aid means that the world is starving China 'into an atomic war'. The Asian famine is referred to as an 'explosion', suggestive of a nuclear blast and an exponentially swelling population. The newly elected Pope must find a resolution to this situation before the Chinese Army takes control of the country and starts a nuclear war. The Soviet Premier uses a dehumanizing metaphor to stress the repercussions of a Chinese invasion of the USSR: 'If the ants move out of the ant heap, there will be rain.'

In a post-nuclear-war New York, the repulsive narrator of Harlan Ellison's 'A Boy and His Dog' (1969) watches a propaganda film from the Third World War, in which the racism directed against the Japanese in the Second has been translated to the Chinese. The narrator describes a scene from the film, entitled 'Smell of a Chink', which features American forces 'jellyburning a Chink town'. ${ }^{45}$ The narrator's language invites readers to see the United States's relation to China as one of racist prejudice, and the fact that the title of the propaganda film uses the same derogatory word suggests that the USA shares the violence and racism of the narrator. The action depicted in the film, the burning of a town, could apply in an altered context to the Vietnam War that was raging while the story was being written. Ellison identified a personal motivation for the short story in the 
American state's murderous repression of anti-Vietnam protesters. ${ }^{46}$ In Edward Bryant's short story 'Jody after the War' (1972), the nuclear war of the title ensued when (in the words of Paul the narrator) 'the Chinese suicided their psychotic society in the seventies, and destroyed most of urban America in the process' ${ }^{47}$ Paul's choice of words imply it is not that the Chinese people are irresponsible or that they endanger neighbouring populations as a swarming mass. They are simply not sane enough to be in control of nuclear weapons. When psychological instability leads the Chinese to immolate themselves, America's cities are caught up in their insanity. This bears out Paul Brians's observation that China demonstrates 'near-suicidal recklessness' 48 in Anglophone nuclear fictions, although how far the reader is meant to trust Paul is unclear, since his glib language suggests emotions are clouding his judgment.

In slightly later nuclear representations, the anxiety surrounding China subsides, but the fear of marauding non-white hordes endures: in M. J. Engh's novel Arslan (1976) the invading army remains explicitly Asian. Their leader, General Arslan from Turkistan, exploits the threat of nuclear weapons to occupy the United States; he is described as 'young, jaunty, halfway Oriental like the second-row extras in Turandot [presumably a reference to Puccini's opera, set in Peking] ${ }^{\prime} .^{49}$ In the American film Red Dawn (1984) the Chinese are America's allies, but the foreignness and savagery of the USA's invaders is established through blunt historical parallel. As the country is attacked by nuclear weapons and invaded by Russian and Latin American soldiers, a High School history class takes place on the Mongol invasions of Asia. The history teacher lectures on the Mongol atrocities - 'once the killing started it lasted days, weeks, even months' - and communist paratroopers drop onto the school playing field, linked by association to the bloodthirsty Mongol forces.

Nonetheless, the selection of Cuban and Nicaraguan invaders was consciously meant to evoke the contemporary geopolitical anxieties of President Reagan's administration. Director John Milius envisaged Red Dawn as a warning against Soviet-sponsored sorties operating out of Central America, with communist agents entering the US posing as 'illegal aliens'. In the film, Cuban and Nicaraguan forces creep over the MexicoUS border in the guise of undocumented workers and neutralize strategic targets, paralyzing the US nuclear defence system. ${ }^{50}$ Red Dawn was made over a hundred years after Atwell Whitney's 1878 novel Almond-Eyed but non-white immigrants still elicit fear as the advance guard of an enemy invasion. 


\section{'Nuke Iran'}

In the 1979 film Cruise Missile, a European co-production and 'an espionage thriller set in Iran', the Soviet Union and the United States work in tandem 'to disrupt a plot to sell tactical nuclear weapons to those non-nuclear states who want to disrupt the Cold War balance of power' ${ }^{51}$ From the late 1970s and throughout the 1980s, historical events focused attention on Western and Central Asia as a possible starting point for a Third World War. ${ }^{52}$ Broderick records that in 1979 a 'probable joint South African-Israeli atmospheric nuclear test [was] detected by [a] U. S. monitoring satellite' ${ }^{53}$ In 1979, the Shah of Iran was deposed in a revolution and replaced by the Ayatollah Khomeini. Iran became an Islamic republic, verbally hostile to America and taking American hostages that would not be released until 1981. Also in 1979, the Soviet Union invaded Afghanistan and when Ronald Reagan was elected President of the United States in 1980 he committed the nation to increase its defence budget by $50 \%$ and refused to ratify the SALT II nuclear arms control treaty with the USSR. ${ }^{54}$ Reagan's belligerence reached into the environs of America's esteemed universities, as Caldicott recalls in the wake of the Iranian Hostage Crisis: 'I saw a young messenger walking through the halls of the Children's Hospital at Harvard, wearing a T-shirt that read "Nuke Iran."'55 W. D. Ehrhart has a similar recollection from 1980: 'Last fall, I went to a Vanderbilt football game. At halftime, a group of students came onto the field with an effigy of Ayatollah Khomeini hanging from a pole and a large banner reading "Nuke Iran". They were clearly having a good time. ${ }^{56}$

A typical scenario is depicted in the British television film Threads (1984), when Cold War brinkmanship over the kind of Soviet expansionism seen in Afghanistan leads to a gradually escalating nuclear conflict that culminates in World War Three. The USSR invades Iran, which leads to provocation between the superpowers' navies, which leads to the use of tactical nuclear weapons, which leads to World War Three. In a variation emphasizing Third-World maliciousness, the American film Def Con 4 (1985) starts by proclaiming that the United States's new Outer Space orbiting nuclear missile space station makes war between East and West impossible, parodying the Reagan administration's pursuit of a nuclear defence system in 1983 (popularly known as 'Star Wars'). Libyans seize a disguised American vessel transporting Cruise Missiles and initiate World War Three between the USA and the USSR.

A striking feature of 1980s nuclear anxiety is that many leftwing critics writing against the nuclear powers combine explicit denunciation of Western nuclear machinations with this trepidation that conflict in the 
Third World will initiate nuclear conflict. Joel Kovel's Against the State of Nuclear Terror (1983) warns 'if nuclear holocaust is to come, it will be most probably by the spreading out of control of one of these wars in the Third World'. While Kovel fears World War Three may originate in the 'Middle East', he argues such a future conflict would most likely be 'an imperialist war raging out of control' fought under the assumption of racial or ethnic superiority:

Israel and South Africa are the most likely by far of any nation to resort to nuclear weapons [...] in part, because of the gross racism of their relations with adversaries. Most of the really hideous exercises of technological slaughter - Nazi versus Jew or Slav, the Americans at Hiroshima or in Vietnam - have occurred in a context of belief in racial superiority, and the present cases of Israel and South Africa are no exception to this attitude. Nothing [...] is more deadly than an imperial technocracy when it faces opposition from a people it considers less than human. ${ }^{57}$

Feminist scholar Helen Caldicott's book Missile Envy: The Arms Race and Nuclear War (1984) contains a chapter whose title needs little exegesis by now: 'Germs of Conflict: The Third World'. This imagining of the Third World as a site of fatal infection causing nuclear war is as offensive as previous characterizations of Third-World peoples as 'natives'. Caldicott picks up Szilard's concern that the relative transportability and anonymity of nuclear weapons makes them the weapon of choice for Third-World nuclear revenge plots:

As the Third World becomes progressively more deprived $[\ldots]$ the new nuclear nations of the world will obviously focus their frustration upon the rich. The anger in many Third World countries toward both the United States and the USSR is overt [...] In the near future, a small nuclear nation could well threaten to, or actually, destroy New York or Moscow. ${ }^{58}$

In the 1964 television movie The Crunch, 'a Middle Eastern state' smuggles the component parts of an atomic bomb into London through diplomatic pouches, assembling the bomb in the basement of their embassy. Their demand is 'one billion pounds as reparation for the period the country spent as a colony', ${ }^{59}$ tying proliferation to the decolonizing world's assertions that the injustices of colonization must be made good. In 1985, the novelist Walter M. Miller Jr acknowledged the threat of 'Allah-fearing backpackers with 68-pound nukes' hitchhiking 'from our beaches to their targets', ${ }^{60}$ but he counselled his readers that the most awesome destruc- 
tive power belongs to the superpowers: 'I'm a lot more afraid of Reagan, Gorbachev, \& Co. than I am of, say, a mini-nuclear state headed by Muammar al-Qaddafi or Fidel Castro. ${ }^{\prime 11}$ Miller suggests that terror of nuclear proliferation has created an unthinking assumption in the West that 'mini-nuclear' states are to be resisted and feared. Why should we be more acceptant of nuclear weapons when they are controlled by rich governments, especially when the only use of those weapons in combat was by one of them?

\section{After the War Has Gone}

By the start of the 1990s, the Soviet Union was being dismantled and the perceived threat of World War Three diminished significantly. The end of the Cold War accelerated the cultural representation of Third-World peoples acquiring nuclear weapons, especially in popular film. Russia's internal crises were seen to have left the country without the authority to monitor its nuclear weapons. David Yost's The US and Nuclear Deterrence in Europe (1999), published by the International Institute for Strategic Studies, warns that some 'of the greatest nuclear uncertainties facing NATO concern the reliability of Russia's measures to protect its nuclear forces from theft, tampering, accidents and diversion'. ${ }^{62}$ Film critic Jerome Shapiro comments of post-Cold War cinema that there is a 'minor industry devoted to just churning out cheap films about stolen nuclear materials and weapons', ${ }^{63}$ and Atomic Train (1999), directed by David Jackson and Dick Lowry, would certainly fit that bill. In Atomic Train, the American President laments, 'we buy Russian [nuclear] weapons to keep them out of the hands of terrorists'. There were big-budget film interpretations of the 'uncertainties' Yost referred to, such as 1997's The Peacemaker, and the James Bond film Tomorrow Never Dies (1997). The pre-title sequence of Tomorrow Never Dies takes place in 'A Terrorist Arms Bazaar on the Russian Border'. Bond, played by Pierce Brosnan and codenamed 'White Knight' for this mission, has gone undercover at the bazaar and is secretly relaying camera footage back to intelligence headquarters. Despite Bond's protests, a British naval vessel launches a long-range missile at the bazaar, but as the missile flies out of range and cannot be recalled, the personnel at headquarters realize their mistake: attached to a jet fighter being sold at the bazaar are 'Soviet SBS nuclear torpedoes'. These are weapons that have leaked out of the crumbling Soviet Union, and a British Admiral turns to his Russian counterpart and snarls, 'Can't you people keep anything locked up?' Bond has to avert disaster by flying the jet fighter out of the locale before the explosion takes place. With seconds to spare, he succeeds (the 
film would have been very short otherwise). The initiative and skill of the 'White Knight' - the codename is instructive - prevent Russia's unsecured nuclear weapons from falling into terrorist hands, or exploding.

The transportable, clandestine nature of nuclear weapons underpins the dramatic tension in James Cameron's 1994 thriller film True Lies, featuring Arnold Schwarzenegger as Harry Tasker, an American secret agent tracking an Islamist terrorist group called Crimson Jihad (this film was made with the assistance of the Pentagon ${ }^{64}$ ). One of Harry's team informs him 'a week ago four [nuclear] MIRV [multiple independently targetable re-entry vehicle] warheads were smuggled out of the former Soviet republic of Kazakhstan', and that Crimson Jihad 'bought the nukes and is trying to bring them onto US soil'. Harry's boss tells the secret agent to gather information on the group 'before somebody parks an automobile in front of the White House with a nuclear weapon in the trunk'. Crimson Jihad was formed by Salim Abu Aziz, a 'psycho' responsible for 'dozens and dozens of car bombs' and 'that café bomb in Rome last year'. Art Malik's performance as Aziz fits the description given by one of his American accomplices, an art dealer called Juno Skinner (played by Tia Carrere): 'they're very well-funded raving psychotics'. Aziz slaps Juno to enforce his orders, and he berates her for 'laughing and flirting like a whore', living up to the stereotype of the misogynistic Muslim fanatic. He leads a prayer as his group prepare to explode one of the warheads: 'In 90 minutes a pillar of fire will light up the sky $[\ldots]$ we are set on our course. No force can stop us now.' Skinner specializes in trading art from Ancient Persia, and she informs Tasker how difficult it is to collect work from this period: 'Iran, Iraq and Syria' occupy the land that Persia once stood on, 'Not the most popular places to live.' She smuggles the four nuclear warheads into the country through Persian statuary: 'I call them the Four Horsemen. They're warrior figures from the Persian empire of Darius the First, 500 BC.' Her reference to Four Horsemen invokes the apocalypse that Crimson Jihad plot to unleash on America's cities and the choice of statuary ties the nuclear threat to the Persian leader who invaded ancient Greece but was defeated at the Battle of Marathon, a symbolically important moment in the rise of Greek civilization. One should be careful not to overemphasize the significance of these details as they are peripheral references in terms of the narrative and relationship between characters. The primary significance of the statuary's origins seems to be underlining Aziz's philistinism when he tears the statues apart for the weapons hidden within. Following Said, we might extrapolate from this scene the following message: contemporary militant Islam is prepared to decimate the artefacts of Asian civilization and by intervening in their actions Western agents are not only 
preserving the peace but acting in the interests of Asia by preserving their cultural treasures. These particular fictional cultural treasures hold the memory of the defence of Greek civilization, and the symbolism lays a similar veneer on the American agent, tasked with defending civilization once more.

True Lies acknowledges that while Aziz's antagonism to the USA is founded in religious, civilizational differences, his immediate goals are political and directed towards the ongoing influence of America in Western Asia. His demands to the US state are that unless America pulls its troops out of the Persian Gulf, 'Crimson Jihad will rain fire on one American city each week.' This terrorist action is not unprovoked: 'You have killed our women and children. Bombed our cities from afar, like cowards. And you dare to call us terrorists?' A similar comment is made by a fictional Arab terrorist in Julian Barnes's novel A History of the World in 10 1/2 Chapters (1989). Upon being told it is unfair to take civilian hostages, the terrorist replies, "There are no civilians any more [...] Your governments pretend, but that is not the case. Those nuclear weapons of yours, they are only to be let off against an army?'65 As Aziz's demands recall, the end of the Cold War and the advent of a 'New World Order' was heralded in the early 1990 s by the Iraqi invasion of Kuwait and the Desert Storm campaign that followed. During Desert Storm, the T-shirt manufacturers busy during the Iranian hostage crisis sensed a repetition of a theme, Stam and Shohat observing the "zealous [American] citizens who sported "Nuke Iraq" Tshirts' ${ }^{66}$ The Disney film Aladdin (1992), emerging in the aftermath of Desert Storm and set in Western Asia, features the character of Genie, a protean figure who at one point transforms into a mushroom cloud. Alan Nadel reads this as a figuration of Iraq's own deceptive, shifting guises, an ally in the 1980s that became an arch nemesis, with the mushroom cloud symbolizing uncertainty over Saddam Hussein's remaining nuclear weapons. ${ }^{67}$

The American television movie Deterrence (1998) crudely mobilizes many of these currents: that nuclear technology sold to the Third World will have disastrous repercussions, Iraq is untrustworthy and has rearmed with 'weapons of mass destruction' since Desert Storm. Set in the near future, when Deterrence begins US troops are stationed along the $38^{\text {th }}$ Parallel (dividing North and South Korea) to prevent a Chinese invasion. American President Emerson is faced with a dilemma when Iraqi dictator Uday Hussein (Saddam's son) invades Kuwait and readies chemical and biological weapons to attack Tel Aviv, Greece and Turkey. Emerson cannot withdraw his armed forces from the $38^{\text {th }}$ Parallel, believing that if America lets the 'domino fall' in South Korea, the Chinese will also invade Japan. 
The answer? Drop a nuclear weapon on Baghdad. The narrative of Deterrence is more complicated than that, but only slightly so. The film's revelation that Iraq has hidden 'weapons of mass destruction' mounted on mobile launching pads is more familiar since the Iraq War that begun in 2003, but not necessarily any more credible. Deterrence's message is that only American nuclear intervention in Asia can preserve the fragile peace across the globe. It is unfortunate that the meaningful strategic concerns represented by Iraqi rearmament in the 1990s are splayed into a dogmatic and obnoxious film.

\section{Nuclear Sheriffs}

The premonition of atomic weapons secretly constructed or smuggled inside Western cities continued into the twenty-first century, particularly in the immediate aftermath of the terrorist attacks of 11 September 2001. Various media texts, state-sponsored and otherwise, informed one how to preserve 'yourself and your family' ${ }^{68}$ should a nuclear weapon be detonated. The spectre of a 'dirty' nuclear device was identified as the most dangerous threat, low in explosive power but fatally high in radioactive contamination, and detonated by the forces on which the UK, the USA and their allies are waging war. ${ }^{69}$ On 27 March 2003, British Prime Minister Tony Blair declared 'the dominant security threat of our time $[\ldots]$ is the combination of weapons of mass destruction in the hands of unstable, repressive states and terrorist groups' ${ }^{70}$ In March 2003, American President George W. Bush explained that the war was necessary because, with access to Iraq's biological, chemical and nuclear weapons, "terrorists could fulfill their stated ambitions and kill thousands or hundreds of thousands of innocent people in our country, or any other' ${ }^{71}$ In the popular television programme 24 (2001-10), first shown in the United States on the Fox Television Network, the counterterrorist agent Jack Bauer (Kiefer Sutherland) repeatedly races against time to stop Islamist terrorists from detonating nuclear bombs or attacking nuclear power plants on US soil. This occurs in series two, four and six, with the terrorists originating from the Middle East or Turkey (a nuclear device does explode in an American conurbation in series six, suggesting the suspense generated by the possibility of a single bomb going off has been somewhat exhausted). The series repeatedly puts the character of Bauer in pressurized situations where he has to make fast, radical moral judgments which he believes are in the interest of America's public safety. Because they safeguard national security, these moral choices are presented in such a way that legitimizes his decisions to torture and murder criminals. With typical understatement, 
theorist Slavoj Žižek compares the antiheroes of 24 to the people who carried out the Holocaust; Žižek understands the series as popular cultural justification for the unilateral actions of US foreign policy. ${ }^{72}$

The rhetoric used by George W. Bush connects the War on Terror to the USA's settlement of North America via Wild West imagery where civilization is imposed by force against belligerent savagery. The language of the American West punctuates Bush's statements on Iraq's alleged possession of nuclear weapons: 'The people of the United States and our friends and allies will not live at the mercy of an outlaw regime that threatens the peace with weapons of mass murder. ${ }^{73}$ President Bush sees himself waging 'a war to save civilisation itself', requiring the 'courage and optimism' that defined frontier society, the 'spirit' in which America 'was born' ${ }^{74}$ Before the Iraq War, Bush made a call-to-arms that included collecting up a 'posse', and has declared that Osama Bin Laden, the head of the Al'Quieda terrorist network that perpetrated the World Trade Center attacks, is 'wanted, dead or alive'..$^{75}$

The threats summoned up by Blair and Bush are not the novel products of a New World Order shaken by terrorist atrocities, of which the September 2001 attacks were the most devastating and shocking. This is not to minimize the unprecedented scale of murder on $9 / 11$, or the suffering and death caused by subsequent terrorist acts in locations such as Bali, Madrid and London. Nor do I wish to suggest that states such as Iraq and Iran have not been or are not building nuclear weapons - an assessment of the status of twenty-first-century proliferation is beyond the scope of this project. What I have attempted to do in this chapter and in this book is demonstrate that nuclear fears, of Third-World states coming into possession of nuclear weapons or terrorists acquiring the materials necessary to build atomic devices, have a long history. That history of nuclear representations has often reproduced the racial, ethnic, national and civilizational hierarchies that grew out of European imperialism and North American settlement, which in turn drew a large part of their epistemological legitimacy from nineteenth-century racial sciences. I hope a fuller grasp of this rich representational history has been provided by attending to these hierarchies and the subtle (and not so subtle) ways they invite certain kinds of reading, viewing and listening experiences. It has not been a one-dimensional story, since writers from Langston Hughes to Walter M. Miller Jr to Octavia Butler, and film directors from Ranald MacDougall to George Miller and George Ogilvie, have found ways to wring out the white supremacism that peppered pre-1945 future-war fictions. Reading nuclear weapons for the 'heart of whiteness' at their core does illustrate the recurring importance of race, ethnicity, nationhood and 
civilization when engaging with these texts, a process that multiples the possibilities offered by nuclear representations. If the reader of Race, Ethnicity and Nuclear War closes the book with that thought, it will have satisfied its intention.

\section{Notes}

1. Rotter, Hiroshima, p. 296.

2. Quoted in Shane J. Maddock, Nuclear Apartheid: The Quest for American Atomic Supremacy from World War II to the Present, University Press of North Carolina Press, Chapel Hill (2010), p. 9.

3. Maddock, Nuclear Apartheid, p. 1.

4. Leo Szilard, 'Atomic Bombs and the Postwar Position of the United States in the World' (1945), in Morton Grodzins and Eugene Rabinowitch (eds), The Atomic Age: Scientists in National and World Affairs, Basic Books, New York (1963), p. 14; see also Seed, American Science Fiction and the Cold War, pp. 19, 58.

5. Nevil Shute, On the Beach, Heinemann, London (1957), p. 11.

6. Shute, On the Beach, pp. 85-88.

7. Leghorn, 'A Rational World Security System', p. 260.

8. Shute, On the Beach, p. 86.

9. C. W. Sullivan III, 'Alas, Babylon and On the Beach: Antiphons of the Apocalypse', in Carl B. Yoke (ed.), Phoenix from the Ashes: The Literature of the Remade World, Greenwood Press, Westport, CT (1987), p. 39.

10. Shute, On the Beach, p. 259.

11. Alvin M. Weinberg, 'Prospects in International Science' (1958), in Morton Grodzins and Eugene Rabinowitch (eds), The Atomic Age: Scientists in National and World Affairs, Basic Books, New York (1963), p. 513.

12. The Vienna Declaration (1958), in Morton Grodzins and Eugene Rabinowitch (eds), The Atomic Age: Scientists in National and World Affairs, Basic Books, New York (1963), pp. 558-64.

13. Tony Shaw, British Cinema and the Cold War (2001), I. B. Tauris, London (2006), p. 123.

14. Cf. Conrad, Heart of Darkness, p. 75.

15. Shaw, British Cinema and the Cold War, p. 124.

16. Quoted in Ernest R. May and Philip D. Zelikow (eds), The Kennedy Tapes: Inside the White House during the Cuban Missile Crisis, Belknap Press and Harvard University Press, Cambridge, MA (1997), p. 181.

17. Ian Fleming, Thunderball, Jonathan Cape, London (1961), p. 75.

18. Fleming, Thunderball, p. 81.

19. Ian Fleming, You Only Live Twice, Jonathan Cape, London (1964), pp. $232-33$.

20. Quoted in Kennedy, 13 Days, p. 137.

21. Fleming, You Only Live Twice, p. 58.

22. Kurt Vonnegut Jr, Cat's Cradle (1963), Penguin, Harmondsworth (1965), pp. 164-65.

23. Vonnegut, Cat's Cradle, p. 9.

24. Stone, Literary Aftershocks, pp. 62-63. 
25. Vonnegut, Cat's Cradle, p. 82.

26. The novel is discussed for its subversive attitude towards the ethos of Western science in Daniel L. Zins, 'Rescuing Science from Technocracy: Cat's Cradle and the Play of Apocalypse', Science Fiction Studies, 13.2 (July 1986). See also Brian Stableford, 'Man-Made Catastrophes', in Eric S. Rabkin, Martin H. Greenberg, and Joseph D. Olander (eds), The End of the World, Southern Illinois University Press, Carbondale (1983), p. 134; Wagar, Terminal Visions, p. 172.

27. Vonnegut, Cat's Cradle, pp. 93, 55.

28. Alondra Nelson, 'Introduction: Future Texts', Social Text, 20.2 (Summer 2002), p. 1.

29. Vonnegut, Cat's Cradle, pp. 56, 88, 54, 57, 90.

30. Vonnegut, Cat's Cradle, p. 7.

31. Peter J. Reed, Kurt Vonnegut, Jr., Warner Paperback Library, New York (1972), pp. 124, 130-33.

32. Vonnegut, Cat's Cradle, p. 128.

33. Reed, Kurt Vonnegut, Jr., pp. 140-45.

34. Walter Benjamin, 'Left-Wing Melancholy' (1931), transl. Ben Brewster, in Michael W. Jennings, Howard Eiland and Gary Smith (eds), Selected Writings (vol. II), Harvard University Press, Cambridge, MA (1999), p. 425.

35. Vonnegut, Cat's Cradle, p. 41.

36. Vonnegut, Cat's Cradle, pp. 68-70.

37. Vonnegut, Cat's Cradle, pp. 147, 22, 95, 87.

38. See Bogle, Toms, Coons, Mulattoes, Mammies, $\theta$ Bucks.

39. Vonnegut, Cat's Cradle, p. 111.

40. Vonnegut, Cat's Cradle, pp. 115, 157, 153.

41. Vonnegut, Cat's Cradle, pp. 133, 163, 179, 147. See Wagar, Terminal Visions, p. 173.

42. Wagar, Terminal Visions, p. 173.

43. Allen Ginsberg, Collected Poems 1947-1980, Viking, London (1985), pp. 371-72.

44. Morris West, The Shoes of the Fisherman, Heinemann, London (1963), pp. 35,220 .

45. Harlan Ellison, 'A Boy and His Dog' (1969), in Walter M. Miller, Jr and Martin H. Greenberg (eds), Beyond Armageddon, University of Nebraska Press, Lincoln, NE (2006), pp. 337-38.

46. Walter M. Miller Jr's introduction to Ellison, 'A Boy and His Dog', pp. 332-33, discusses Ellison's motivation to write the short story.

47. Edward Bryant, 'Jody after the War' (1972), in Walter M. Miller, Jr and Martin H. Greenberg (eds), Beyond Armageddon, University of Nebraska Press, Lincoln, NE (2006), p. 118.

48. Brians, Nuclear Holocausts, p. 36.

49. M. J. Engh, Arslan (1976), Orb and Tom Doherty Associates, New York (2001), p. 3. Arslan is considered in more detail in Martha A. Bartter, 'The Hidden Agenda', in George Slusser and Eric S. Rabkin (eds), Fights of Fancy: Armed Conflict in Science Fiction and Fantasy, The University of Georgia Press, 
Athens, GA (1993), pp. 155-69.

50. Tony Shaw, Hollywood's Cold War, Edinburgh University Press, Edinburgh (2007), p. 273.

51. Toni A. Perrine, Film and the Nuclear Age: Representing Cultural Anxiety, Garland, New York (1998), p. 129.

52. Brians, Nuclear Holocausts, pp. 36-37.

53. Broderick, Nuclear Movies, p. 126.

54. Weart, Nuclear Fear, pp. 377-78.

55. Helen Caldicott, Missile Envy: The Arms Race and Nuclear War, Morrow, New York (1984), p. 102.

56. W. D. Ehrhart, 'Address to Middle America' (1980), in Jan Barry (ed.), Peace Is Our Profession: Poems and Passages of War Protest, East River Anthology, Montclair, NJ (1981), p. 276.

57. Kovel, Against the State of Nuclear Terror, pp. 210-11.

58. Caldicott, Missile Envy, pp. 90, 50.

59. Newman, Apocalypse Movies, p. 206. The BFI online Film and Television Database places the country in East Asia.

60. Walter M. Miller Jr's introduction to Ray Bradbury, 'There Will Come Soft Rains,' Walter M. Miller Jr and Martin H. Greenberg (eds), Beyond Armageddon, University of Nebraska Press, Lincoln, NE (2006), p. 253.

61. Walter M. Miller Jr, introduction, in Walter M. Miller, Jr and Martin H. Greenberg (eds), Beyond Armageddon, University of Nebraska Press, Lincoln, NE (2006), p. xvi.

62. David S. Yost, The US and Nuclear Deterrence in Europe, Oxford University Press and International Institute for Strategic Studies, Oxford (1999), p. 52.

63. Shapiro, Atomic Bomb Cinema, p. 218. See also Newman, Apocalypse Movies, p. 209.

64. Shaw, Hollywood's Cold War, p. 305.

65. Julian Barnes, A History of the World in $10 \mathrm{l} / 2$ Chapters (1989), Picador, London (1990), p. 51.

66. Shohat and Stam, Unthinking Eurocentrism, p. 128.

67. Alan Nadel, 'A Whole New (Disney) World Order: Aladdin, Atomic Power, and the Muslim Middle East', in Matthew Bernstein and Gaylyn Studlar (eds), Visions of the East: Orientalism on Film, Rutgers University Press, New Brunswick, NJ (1997).

68. Anon., Preparing for Emergencies: What You Need to Know, Her Majesty's Stationary Office, London (2004).

69. See Dirty War, dir. Daniel Percival, prod. Luke Alvin, BBC 1 (26 Sept. 2004).

70. Tony Blair and George W. Bush, 'President Bush, Prime Minister Blair Hold Press Availability' (27 Mar. 2003), available at The White House, http://www.whitehouse.gov/news/releases/2003/03/20030327-3.html (last accessed October 2004).

71. George W. Bush, 'President Says Saddam Hussein Must Leave Iraq within 48 Hours' (17 Mar. 2003), available at The White House, 
http://www.whitehouse.gov/news/releases/2003/03/20030317-7.html (last accessed Oct. 2004).

72. Slavoj Žižek, 'The Depraved Heroes of 24 are the Himmlers of Hollywood', Guardian (10 Jan. 2006), available at http://www.guardian.co.uk/ comment/story/0,3604, 1682760,00.html (last accessed June 2007).

73. George W. Bush, 'President Discusses Beginning of Operation Iraqi Freedom' (22 Mar. 2003), available at The White House, http://www.whitehouse.gov/news/releases/2003/03/20030322.html (last accessed Oct. 2004).

74. George W. Bush, 'In Address to the Nation' (8 Nov. 2001), available at The White House, http://www.whitehouse.gov/news/releases/2001/11/ 20011108-13.html (last accessed Aug. 2002).

75. Karen Dodwell, 'From the Center: The Cowboy Myth, George W. Bush, and the War with Iraq' (Mar. 2004), available at Magazine Americana, http:// www.americanpopularculture.com/archive/politics/cowboy_myth.htm (last accessed Aug. 2010). 


\section{Bibliography}

Abbott, Carl, 'Homesteading on the Extraterrestrial Frontier', Science Fiction Studies, 32.2 (July 2005), pp. 240-64.

Abdulahad, Tania, Gwendolyn Rogers, Barbara Smith and Jameelah Waheed, 'Black Lesbian / Feminist Organizing: A Conversation', in Barbara Smith (ed.), Home Girls: A Black Feminist Anthology (2nd edn), Rutgers University Press, New Brunswick, NJ (2000).

Abraham, Itty, The Making of the Indian Atomic Bomb, Zed Books, London (1998).

Achebe, Chinua, 'An Image of Africa: Racism in Conrad's Heart of Darkness' (1977), in Joseph Conrad, Heart of Darkness (3rd edn), ed. Robert Kimbrough, Norton, New York (1988).

Adorno, Theodor W., Minima Moralia: Reflections from Damaged Life (1951), transl. E. F. N. Jephcott, Verso, London (1978).

-, 'Commitment' (1965), in Dennis Walder (ed.), Literature in the Modern World: Critical Essays and Documents, Oxford University Press and The Open University, Oxford (1990).

—, Negative Dialectics, transl. E. B. Ashton, Routledge, London (1973).

Ahern, Jerry, Total War (1981) (vol. I of the Survivalist series), New English Library, Sevenoaks, Kent (1985).

-, The Nightmare Begins (1981) (vol. II of the Survivalist series), New English Library, Sevenoaks, Kent (1984).

-, The Quest (1981) (vol. III of the Survivalist series), New English Library, Sevenoaks, Kent (1984).

Ahmed, Samina, David Cortright and Amitabh Mattoo, 'Public Opinion and Nuclear Options for South Asia', Asian Survey, 38.8 (Aug. 1998), pp. 727-44.

Ames, Nathaniel, An Astronomical Diary: or, An Almanack for the Year of Our Lord Christ 1758, J. Draper, Boston (undated).

Amis, Martin, 'The Immortals', in Einstein's Monsters, Penguin, Harmondsworth (1988).

Anderson, Benedict, Imagined Communities (rev. edn), Verso, London (2006).

Anderson, Jervis, Bayard Rustin: Troubles I've Seen, University of California Press, Berkeley (1998).

Anderson, Poul [and F. N. Waldrop], 'Tomorrow's Children' (1947), in Walter M. Miller, Jr and Martin H. Greenberg (eds), Beyond Armageddon, University of Nebraska Press, Lincoln, NE (2006).

Anon., 'Atomic Age: Manhattan District', Time (20 Aug. 1945), http://www.time. com/time/magazine/article/0,9171,797665-2,00.html (last accessed July 2010).

Anon., 'The Bomb', Time (20 Aug. 1945), http://www.time.com/time/magazine/article/0,9171,797639,00.html (last accessed July 2010).

Anon., Preparing for Emergencies: What You Need to Know, Her Majesty's Stationary Office, London (2004).

Appiah, Kwame Anthony, 'Race', in Frank Lentricchia and Thomas McLaughlin (eds), Critical Terms for Literary Study (2nd edn), The University of Chicago Press, Chicago (1995). 
Ataöv, Türkhaya, Kashmir and Neighbours: Tale, Terror, Truce, Ashgate, Aldershot (2001).

Attridge, Derek, J. M. Coetzee and the Ethics of Reading: Literature in the Event, University of Chicago Press, Chicago (2004).

—, The Singularity of Literature, Routledge, London (2004).

Baldwin, James, 'Nobody Knows My Name: A Letter from the South' (1959), in idem, The Price of the Ticket: Collected Non-Fiction, 1948-1985, St Martin's Press, New York (1985).

—, 'Fifth Avenue, Uptown: A Letter from Harlem' (1960), in idem, The Price of the Ticket: Collected Non-Fiction, 1948-1985, St Martin's Press, New York (1985).

—, The Fire Next Time (1963), Penguin, Harmondsworth (1964).

Balibar, Etienne, and Immanuel Wallerstein, Race, Nation, Class: Ambiguous Identities (1988), transl. Chris Turner, Verso, London (1991).

Ballard, J. G., 'The Terminal Beach', in idem, The Terminal Beach (1964), Dent, London (1984).

Barker, Martin, and Roger Sabin, The Lasting of the Mohicans: History of an American Myth, University Press of Mississippi, Jackson, MS (1996).

Barnes, Julian, A History of the World in $10^{1 / 2}$ Chapters (1989), Picador, London (1990).

Barton, Samuel, The Battle of the Swash; and The Capture of Canada, New York (1888).

Bartter, Martha A., 'Nuclear Holocaust as Urban Renewal', Science Fiction Studies, 13.2 (July 1986), pp. 148-58.

-, 'The Hidden Agenda', in George Slusser and Eric S. Rabkin (eds), Fights of Fancy: Armed Conflict in Science Fiction and Fantasy, The University of Georgia Press, Athens, GA (1993).

Beauvoir, Simone de, The Second Sex (1949), Vintage, London (1997).

Benjamin, Walter, 'Left-Wing Melancholy' (1931), transl. Ben Brewster, in Michael W. Jennings, Howard Eiland and Gary Smith (eds), Selected Writings (vol. II), Harvard University Press, Cambridge, MA (1999).

Berger, James, After the End: Representations of Post-Apocalypse, University of Minnesota Press, Minneapolis (1999).

Bewley-Taylor, David R., 'Watch This Space: Civil Liberties, Concept Wars and the Future of the Urban Fortress', Journal of American Studies, 40.2 (Aug. 2006), pp. 233-55.

Biddle, Tami Davis, Rhetoric and Reality in Air Warfare, Princeton University Press, Princeton (2002).

Blair, Tony, and George W. Bush, 'President Bush, Prime Minister Blair Hold Press Availability' (27 Mar. 2003), The White House, http://www.whitehouse.gov/ news/releases/2003/03/20030327-3.html (last accessed Oct. 2004).

Bodey, Michael, 'Mad Max Movie Grinds to a Halt', The Australian (7 July 2010), http://www.theaustralian.com.au/news/nation/mad-max-movie-grinds-to-ahalt/story-e6frg6nf-1225888700431 (last accessed July 2010).

Bogle, Donald, Toms, Coons, Mulattoes, Mammies, $\theta$ Bucks: An Interpretive History of Blacks in American Films (3rd edn), Roundhouse, Oxford (1994).

Booker, M. Keith, Monsters, Mushroom Clouds, and the Cold War: American Science Fiction and the Roots of Postmodernism, 1946-1964, Greenwood, Westport, CT (2001).

Bould, Mark, 'The Ships Landed Long Ago: Afrofuturism and Black SF', Science Fiction Studies, 34.2 (July 2007), pp. 177-86.

Bourne, Randolph, 'Trans-National America' (1916), in Paul Lauter (gen. ed.), The Heath Anthology of American Literature (4th edn, vol. II), Houghton Mifflin, Boston (2002). 
Boyer, Paul, By the Bomb's Early Light: American Thought and Culture at the Dawn of the Atomic Age (2nd edn), University of North Carolina Press, Chapel Hill (1994).

Brackett, Leigh, The Long Tomorrow, Doubleday, Garden City, NY (1955).

Bradbury, Ray, The Martian Chronicles (1950; originally titled The Silver Locusts), Voyager and Harper, London (2008).

—, 'The Other Foot', in idem, The Illustrated Man (1951), Corgi, London (1974).

Brathwaite, Edward Kamau, 'Mont Blanc' (1987), in E. A. Markham (ed.), Hinterland: Caribbean Poetry from the West Indies $\theta$ Britain (2nd edn), Bloodaxe, Newcastle-upon-Tyne (1995).

Brennan, Timothy, 'The National Longing for Form', in Homi K. Bhabha (ed.), Nation and Narration, Routledge, London (1990).

Brians, Paul, Nuclear Holocausts: Atomic War in Fiction, 1895-1984, Kent State University Press, Kent, OH (1987).

- 'Nuclear War Fiction for Young Readers: A Commentary and Annotated Bibliography', in Philip John Davies (ed.), Science Fiction, Social Conflict and War, Manchester University Press, Manchester (1990).

Brin, David, The Postman (1985), Bantam, Toronto (1987).

Brock, William E., 'Memo to President Reagan on Japanese Trade Barriers' (18 Dec. 1981), National Security Archive, George Washington University, http://www.gwu.edu/ nsarchiv/NSAEBB/NSAEBB175/japan2-06.pdf (last accessed July 2009).

Broderick, Mick, Nuclear Movies: A Critical Analysis and Filmography of International Feature Length Films Dealing with Experimentation, Aliens, Terrorism, Holocaust and Other Disaster Scenarios, 1914-1989, McFarland, Jefferson, NC (1991).

-, 'Heroic Apocalypse: Mad Max, Mythology, and the Millennium', in Christopher Sharrett (ed.), Crisis Cinema: The Apocalyptic Idea in Postmodern Narrative Film, Maissoneuve, Washington, DC (1993).

Brogan, Hugh, The Penguin History of the USA (2nd edn), Penguin, London (2001).

Brown, Frederic, and Mack Reynolds, 'Dark Interlude' (1951), in Allen deGraeff (ed.), Humans and Other Beings, Collier, New York (1963).

Brunner, Edward, Cold War Poetry, University of Illinois Press, Urbana, IL (2001).

Bryant, Edward, 'Jody after the War' (1972), in Walter M. Miller, Jr and Martin H. Greenberg (eds), Beyond Armageddon, University of Nebraska Press, Lincoln, NE (2006).

Budiansky, Stephen, Air Power, Viking and Penguin, London (2003).

Buruma, Ian, and Avishai Margalit, Occidentalism: A Short History of Anti-Westernism, Atlantic Books, London (2004).

Bush, George W., 'In Address to the Nation' (8 Nov. 2001), The White House, http://www.whitehouse.gov/news/releases/2001/11/20011108-13.html (last accessed Aug. 2002).

—, 'President Says Saddam Hussein Must Leave Iraq within 48 Hours' (17 Mar. 2003), The White House, http://www.whitehouse.gov/news/releases/2003/03/ 20030317-7.html (last accessed Oct. 2004).

—, 'President Discusses Beginning of Operation Iraqi Freedom' (22 Mar. 2003), The White House, http://www.whitehouse.gov/news/releases/2003/03/20030322.html (last accessed Oct. 2004).

Butler, Octavia E., Dawn (1987), Aspect and Warner, New York (1997).

—, Lilith's Brood (1987-89), Grand Central Publishing, New York (2000).

-, 'The Monophobic Response' (1995), in Sheree Thomas (ed.), Dark Matter: A Century of Speculative Fiction from the African Diaspora, Aspect and Time Warner, New York (2000). 
-, 'Interview with Joshunda Sanders' (2004), In Motion Magazine, http://www.inmotionmagazine.com/ac04/obutler.html (last accessed Aug. 2010).

Byron, George Gordon, Lord, 'Childe Harold's Pilgrimage' (1812-18), in Jerome J. McGann (ed.), The Complete Poetical Works (vol. II), Clarendon Press, Oxford (1980).

Bywater, Hector C., The Great Pacific War: A History of the American-Japanese Campaign of 1931-33, Constable \& Co., London (1925).

Caldicott, Helen, Missile Envy: The Arms Race and Nuclear War, Morrow, New York (1984).

Cannadine, David, Ornamentalism: How the British Saw Their Empire, Allen Lane, London (2001).

Caputi, Jane, 'The Heart of Knowledge: Nuclear Themes in Native American Thought and Literature', American Indian Culture and Research Journal, 16.4 (1992), pp. 1-27.

Carey, John (ed.), The Faber Book of Utopias, Faber, London (1999).

Carroll, Mark, Music and Ideology in Cold War Europe, Cambridge University Press, Cambridge (2003).

Carter, Angela, Heroes and Villains (1969), Pan and Picador, London (1972).

Carter, Paul, The Road to Botany Bay: An Essay in Spatial History, Faber, London (1987).

Cash, W. J., The Mind of the South, Thames and Hudson, London (1971).

Ceadel, Martin, 'Popular Fiction and the Next War, 1918-39', in Frank Gloversmith (ed.), Class, Culture and Social Change: A New View of the 1930s, Harvester Press, Brighton (1980).

Chandhoke, Neera, 'Security in Times of Hindutva?', in Satu P. Limaye, Mohan Malik and Robert G. Wirsing (eds), Religious Radicalism and Security in South Asia, Asia-Pacific Center for Security Studies, Honolulu (2004).

Chandra, Vikram, Sacred Games (2006), Faber, London (2007).

Clark, Clifford Edward, Jr, The American Family Home 1800-1960, University of North Carolina Press, Chapel Hill (1986).

Clarke, I. F., Voices Prophesying War: Future Wars 1763-3749 (2nd edn), Oxford University Press, Oxford (1992).

Clarkson, Helen, The Last Day, Dodd Mead, New York (1959).

Cloete, Stuart, 'The Blast', Colliers (12 Apr. 1947), pp. 11-14, 59-71, and (19 Apr. 1947), pp. 19, 69-87.

Cohen, G. A., Letter, London Review of Books, 9.21 (26 Nov. 1987), http://www.lrb. co.uk/v09/n21/letters (last accessed July 2010).

Connor, Steven, 'The Impossibility of the Present: or, From the Contemporary to the Contemporal', in Roger Luckhurst and Peter Marks (eds), Literature and the Contemporary: Fictions and Theories of the Present, Longman, Harlow (1999).

Conrad, Joseph, Heart of Darkness (1899), Penguin, Harmondsworth (1973).

Cooper, James Fenimore, The Last of the Mohicans (1826), Penguin, Harmondsworth (1994).

Cooper, Ken, 'The Whiteness of the Bomb', in Richard Dellamora (ed.), Postmodern Apocalypse: Theory and Cultural Practice at the End, University of Pennsylvania Press, Philadelphia (1995).

Corbridge, Stuart, and John Harris, Reinventing India: Liberalization, Hindu Nationalism and Popular Democracy, Polity Press, Cambridge (2000).

Cordle, Daniel, 'Cultures of Terror: Nuclear Criticism during and since the Cold War', Literature Compass, 3.6 (2006), http://0-www3.interscience.wiley.com.lib. exeter.ac.uk/cgi-bin/fulltext/1 18578161/HTMLSTART (last accessed July 2010). 
-, States of Suspense: The Nuclear Age, Postmodernism and United States Fiction and Prose, Manchester University Press, Manchester (2008).

Cortright, David, 'India's Nuclear Challenge', Peacework, 286 (June 1998), pp. 45.

Coward, Noël, 'Mad Dogs and Englishmen' (1934), in Chris Brooks and Peter Faulkner (eds), The White Man's Burdens: An Anthology of British Poetry of the Empire, University of Exeter Press, Exeter (1996).

Crèvecoeur, J. Hector St John de, Letters from an American Farmer (1782), Oxford World's Classics, Oxford (2009).

Davis, Chandler, 'Nightmare', in Astounding Science Fiction (May 1946).

Davis, Mike, City of Quartz (1990), Vintage, New York (1992).

DeBlasio, Donna M., 'Future Imperfect: Leigh Brackett's The Long Tomorrow', in Carl B. Yoke (ed.), Phoenix from the Ashes: The Literature of the Remade World, Greenwood Press, Westport, CT (1987).

Delany, Samuel R., The Jewels of Aptor (1968), Sphere Books, London (1977).

DeLoughrey, Elizabeth, 'Radiation Ecologies and the Wars of Light', Modern Fiction Studies, 55.3 (Fall 2009), pp. 468-98.

Dippie, Brian W., The Vanishing American: White Attitudes and U.S. Indian Policy, Wesleyan University Press, Middletown, CT (1982).

Dixon, Thomas, The Fall of a Nation: A Sequel to The Birth of a Nation, D. Appleton 8 Company, New York (1916).

Dixon, Wheeler Winston, Visions of the Apocalypse: Spectacles of Destruction in American Cinema, Wallflower, London (2003).

Dodwell, Karen, 'From the Center: The Cowboy Myth, George W. Bush, and the War with Iraq' (Mar. 2004), Magazine Americana, http://www.americanpopularculture.com/archive/politics/cowboy_myth.htm (last accessed Aug. 2010).

Donnelly, Hugh Grattan ['Stochastic'], The Stricken Nation (1890), in I. F. Clarke (ed.), The Tale of the Next Great War, 1871-1914: Fictions of Future Warfare and of Battles Still-to-Come, Liverpool University Press, Liverpool (1995).

Donnelly, Ignatius, Caesar's Column: A Story of the Twentieth Century (1891), in John Carey (ed.), The Faber Book of Utopias, Faber, London (1999).

Dooner, Pierton W., Last Days of the Republic (1880), Arno, New York (1978).

Dorris, Michael, and Louise Erdrich, 'The Day after Tomorrow: Novelists at Armageddon', in Nancy Anisfield (ed.), The Nightmare Considered: Critical Essays on Nuclear War Literature, Bowling Green State University Popular Press, Bowling Green, OH (1991).

Douglass, Frederick, Narrative of the Life of Frederick Douglass, an American Slave, Written by Himself (1845), ed. William L. Andrews and William S. McFeely, Norton, New York (1997).

—, 'Men of Color, To Arms!' (1863), in William L. Andrews (ed.), The Oxford Frederick Douglass Reader, Oxford University Press, New York (1996).

Dower, John W., War without Mercy: Race and Power in the Pacific War (1986), Pantheon, New York (1993).

Dowling, David, Fictions of Nuclear Disaster, Macmillan, London (1987).

Du Bois, W. E. B., The Souls of Black Folk (1903), Vintage and Library of America, New York (1990).

—, 'The Comet', in idem, Darkwater: Voices from within the Veil (1920), Schocken Books, New York (1969).

Dudziak, Mary L., Cold War Civil Rights: Race and the Image of American Democracy, Princeton University Press, Princeton (2000).

Dunn, Thomas P., 'The Road Warrior: Self and Society in the Rebuilding Process', 
in Carl B. Yoke (ed.), Phoenix from the Ashes: The Literature of the Remade World, Greenwood Press, Westport, CT (1987).

Dutt, Soshee Chunder, 'The Republic of Orissa: A Page from the Annals of the Twentieth Century' (1845), in idem, Bengaliana: A Dish of Rice and Curry, and Other Indigestible Ingredients, Thacker, Spink and Company, Calcutta (1885).

Dyer, Richard, White, Routledge, London (1997).

Ehrhart, W. D., 'Address to Middle America' (1980), in Jan Barry (ed.), Peace Is Our Profession: Poems and Passages of War Protest, East River Anthology, Montclair, NJ (1981).

Ellis, John, The Social History of the Machine Gun, John Hopkins University Press, Baltimore (1986).

Ellison, Harlan, 'A Boy and His Dog' (1969), in Walter M. Miller, Jr and Martin H. Greenberg (eds), Beyond Armageddon, University of Nebraska Press, Lincoln, NE (2006).

Ellison, Ralph Waldo, Invisible Man (1952), Penguin, London (1965).

Engh, M. J., Arslan (1976), Orb and Tom Doherty Associates, New York (2001).

Evans, Joyce A., Celluloid Mushroom Clouds: Hollywood and the Atomic Bomb, Westview and Perseus, Oxford (1998).

Fanon, Frantz, Black Skin, White Masks (1952), transl. Charles Lam Markmann, MacGibbon \& Kee, London (1968).

Fitting, Peter, 'You're History, Buddy: Postapocalyptic Visions in Recent Science Fiction Film', in George Slusser and Eric S. Rabkin (eds), Fights of Fancy: Armed Conflict in Science Fiction and Fantasy, The University of Georgia Press, Athens, GA (1993).

Fitzgerald, F. Scott, 'Echoes of the Jazz Age' (1931), in The Bodley Head Scott Fitzgerald (rev. edn, vol. III), Bodley Head, London (1965).

Fleming, Ian, Thunderball, Jonathan Cape, London (1961).

—, You Only Live Twice, Jonathan Cape, London (1964).

Foertsch, Jacqueline, "Extraordinarily Convenient Neighbors": African-American Characters in White-Authored Post-Atomic Novels', Journal of Modern Literature, 30.4 (Summer 2007), pp. 122-38.

Forman, James D., Doomsday Plus Twelve, Scribner's, New York (1984).

Forrest, D. W., Francis Galton: The Life and Work of a Victorian Genius, Elek, London (1974).

Frank, Pat, Alas Babylon (1959), Pan, London (1961).

Franklin, H. Bruce, War Stars: The Superweapon and the American Imagination, Oxford University Press, New York (1988).

—, 'Eternally Safe for Democracy: The Final Solution of American Science Fiction', in Philip John Davies (ed.), Science Fiction, Social Conflict and War, Manchester University Press, Manchester (1990).

Freeman, Joshua B., 'Labor during the American Century: Work, Workers, and Unions Since 1945', in Jean-Christophe Agnew and Roy Rosenzweig (eds), A Companion to Post-1945 America (2002), Blackwell, Oxford (2006).

Gaiman, Neil, and John Watkiss, 'Soft Places' (July 1992), in The Sandman: Fables and Reflections, Titan, London (1994).

George, Alice L., Awaiting Armageddon: How Americans Faced the Cuban Missile Crisis, University of North Carolina Press, Chapel Hill (2003).

George, James, Ocean Roads, Huia, Wellington, NZ (2006).

Georgi, Dieter, 'The Bombings of Hiroshima', Harvard Magazine (Mar.-Apr. 1985), p. 64.

Gibbons, Floyd, The Red Napoleon, Brentano, New York (1929). 
Gibson, Ross, 'Formative Landscapes', in Scott Murray (ed.), Australian Cinema, Allen \& Unwin and Australian Film Commission, St Leonard's, NSW (1994). Giesy, John Ulrich, All for His Country, Macaulay, New York (1915).

Gilroy, Paul, The Black Atlantic: Modernity and Double Consciousness (1993), Verso, London (1996).

-, Against Race: Imagining Political Culture beyond the Color Line, Harvard University Press, Cambridge, MA (2000).

- After Empire: Melancholia or Convivial Culture?, Routledge, London (2004).

- Darker Than Blue: On the Moral Economies of Black Atlantic Culture, Belknap Press of Harvard University Press, Cambridge, MA (2010).

Ginsberg, Allen, Collected Poems 1947-1980, Viking, London (1985).

Glazer, Joan I., 'Nuclear Holocaust in Contemporary Children's Fiction: A Surprising Amount of Agreement', Children's Literature Association Quarterly, 11.2 (Summer 1986), pp. 85-88.

Godden, Richard, 'William Faulkner', in Richard Gray and Owen Robinson (eds), A Companion to the Literature and Culture of the American South, Blackwell, Malden, MA (2004).

Gopal, Priyamvada, The Indian English Novel: Nation, History, and Narration, Oxford University Press, Oxford (2009).

Gould, Stephen Jay, The Mismeasure of Man (rev. edn), Penguin, Harmondsworth (1997).

Gray, Richard, A History of American Literature, Blackwell, Malden, MA (2004).

Griffith, George, The Angel of the Revolution: A Tale of the Coming Terror, Tower, London (1893).

-, The Great Pirate Syndicate, F. V. White \& Co., London (1899).

Gunesekera, Romesh, The Sandglass (1998), Granta, London (1999).

Haig, Alexander et al., 'Memo of Conversation with Japan on General Foreign Policy, Automobiles, Defense, and North South' (23 Mar. 1981), National Security Archive, George Washington University, http://www.gwu.edu/ nsarchiv/ NSAEBB/NSAEBB 175/japan2-04.pdf (last accessed July 2009).

Hamilton, Edmond, 'The Conquest of Two Worlds' (1932), in Leigh Brackett (ed.), The Best of Edmond Hamilton, Ballantine, New York (1977).

Hamilton, George, Experiences of a Colonist Forty Years Ago, Adelaide (1880).

Haney López, Ian F., 'The Social Construction of Race' (2000), in Julie Rivkin and Michael Ryan (eds), Literary Theory: An Anthology (2nd edn), Blackwell, Malden, MA (2004).

Hansen, Thomas Blom, The Saffron Wave: Democracy and Hindu Nationalism, Princeton University Press, Princeton (1999).

Hardy, Phil (ed.), The Aurum Film Encyclopedia: Science Fiction, Aurum Press, London (1984).

Harper, Donna Akiba Sullivan, Not So Simple: The 'Simple' Stories by Langston Hughes, University of Missouri Press, Columbia, MO (1995).

Haut, Woody, Pulp Culture: Hardboiled Fiction and the Cold War, Serpent's Tail, London (1995).

Hay, William Delisle, Three Hundred Years Hence (1881), in I. F. Clarke (ed.), British Future Fiction (vol. II), Pickering \& Chatto, London (2001).

Heinlein, Robert, The Day after Tomorrow (1941; originally titled Sixth Column), Signet, New York (1951).

—, Farnham's Freehold (1964), Dennis Dobson, London (1974).

Henrikson, Margot A., Dr. Strangelove's America: Society and Culture in the Atomic Age, University of California Press, Berkeley (1997). 
Hersey, John, Hiroshima (1946) (new chapter), Penguin, Harmondsworth (1986). Hewlett, Jamie, and Alan Martin, Tank Girl, Penguin, Harmondsworth (1990).

Hoban, Russell, Riddley Walker (1980), expanded edition, Indiana University Press, Bloomington (1998).

Hoffman, Donald L., 'A Darker Shade of Grail: Questing at the Crossroads in Ishmael Reed's Mumbo Jumbo', Callaloo, 17.4 (Autumn 1994), pp. 1245-56.

Honeyford, Ray, 'Anti-Racist Rhetoric', in Frank Palmer (ed.), Anti-Racism: An Assault on Education and Value, Sherwood Press, London (1986).

Horne, Gerald, Black and Red: W. E. B. Du Bois and the Afro-American Response to the Cold War, 1944-1963, State University of New York Press, Albany, NY (1986).

-, 'Race from Power: U. S. Foreign Policy and the General Crisis of White Supremacy', in Brenda Gayle Plummer (ed.), Window on Freedom: Race, Civil Rights, and Foreign Affairs 1945-1988, University of North Carolina Press, Chapel Hill (2003).

Hughes, Langston, Selected Poems (1959), Serpent's Tail, London (1999).

-, The Best of Simple, Hill and Wang, New York (1961).

- Simple's Uncle Sam, Hill and Wang, New York (1965).

Huxley, Aldous, Ape and Essence (1949), Chatto \& Windus, London (1966).

Irving, Washington, A History of New York (1809), in History, Tales and Sketches, Library of America, New York (1983).

Irwin, Robert, For Lust of Knowing: The Orientalists and Their Enemies, Allen Lane, London (2006).

Jackson, Kenneth T., Crabgrass Frontier: The Suburbanization of the United States, Oxford University Press, New York (1985).

Jacobs, Naomi, 'Posthuman Bodies and Agency in Octavia Butler's Xenogenesis', in Raffaella Baccolini and Tom Moylan (eds), Dark Horizons: Science Fiction and the Dystopian Imagination, Routledge, New York (2003).

Jacobs, Robert, 'Target Earth: The Origins of the Image of the Whole Earth in the Ashes of Hiroshima and Nagasaki', in Robert Jacobs (ed.), Filling the Hole in the Nuclear Future: Art and Popular Culture Respond to the Bomb, Lexington Books, Lanham, MD (2010).

James, Edward, 'Yellow, Black, Metal and Tentacled: The Race Question in American Science Fiction', in Philip John Davies (ed.), Science Fiction, Social Conflict and War, Manchester University Press, Manchester (1990).

James, Lawrence, Raj: The Making of British India (1997), Abacus, London (1998).

Jameson, Fredric, The Political Unconscious: Narrative as a Socially Symbolic Act, Methuen, London (1981).

Jaskoski, Helen, 'Thinking Woman's Children and the Bomb', in Nancy Anisfield (ed.), The Nightmare Considered: Critical Essays on Nuclear War Literature, Bowling Green State University Popular Press, Bowling Green, OH (1991).

Johnson, Denis, Fiskadoro (1985), HarperPerennial, New York (1995).

Johnson, Rob, A Region in Turmoil: South Asian Conflicts since 1947, Reaktion Books, London (2005).

Jones, Rodney W., 'America's War on Terror: Religious Radicalism and Nuclear Confrontation in South Asia', in Satu P. Limaye, Mohan Malik and Robert G. Wirsing (eds), Religious Radicalism and Security in South Asia, Asia-Pacific Center for Security Studies, Honolulu (2004).

Jordan, June, 'From Sea to Shining Sea' (1980), in Barbara Smith (ed.), Home Girls: A Black Feminist Anthology (2nd edn), Rutgers University Press, New Brunswick, NJ (2000).

—, 'Who Would Be Free, Themselves Must Strike the Blow', in John Witte (ed.), 
Warnings: An Anthology on the Nuclear Peril, Northwest Review, Eugene, OR (1984).

Jordan, Winthrop D., White over Black: American Attitudes towards the Negro, 15501812, University of North Carolina Press, Chapel Hill (1968).

Joshi, Ruchir, The Last Jet-Engine Laugh (2001), Flamingo, London (2002).

Juergensmeyer, Mark, Terror in the Mind of God: The Global Rise of Religious Violence (3rd edn), University of California Press, Berkeley (2003).

Kalaidjian, Walter, 'Nuclear Criticism', Contemporary Literature, 40.2 (Summer 1999), pp. 311-18.

Kanon, Joseph, Los Alamos (1997), Abacus, New York (1998).

Kawada, Louise, 'Enemies of Despair: American Women Poets Confront the Threat of Nuclear Destruction', PLL: Papers on Language e Literature, 26.1 (Winter 1990), pp. 112-33.

Kennedy, Robert F., 13 Days: The Cuban Missile Crisis, Pan, London (1969).

Kerslake, Patricia, Science Fiction and Empire, Liverpool University Press, Liverpool (2007).

Kinchy, Abby J., 'African Americans in the Atomic Age: Postwar Perspectives on Race and the Bomb, 1945-1967', Technology and Culture, 50.2 (Apr. 2009), pp. 291-315.

King, Martin Luther, Jr, 'Acceptance Speech' (10 Dec. 1964), Nobelprize.org, http://nobelprize.org/nobel_prizes/peace/laureates/1964/king-acceptance. html (last accessed Aug. 2010).

—, 'Nobel Lecture: The Quest for Peace and Justice' (1 1 Dec. 1964), Nobelprize.org, http://nobelprize.org/nobel_prizes/peace/laureates/1964/kinglecture.html (last accessed Aug. 2010).

—, Why We Can't Wait (1964), New American Library, New York (2000).

King, Richard H., 'American Political Culture since 1945', in Jean-Christophe Agnew and Roy Rosenzweig (eds), A Companion to Post-1945 America (2002), Blackwell, Oxford (2006).

Kipling, Rudyard, 'Thrown Away', in idem, Plain Tales from the Hills (1890), Macmillan, London (1900).

-, 'The White Man's Burden' (1898), in Chris Brooks and Peter Faulkner (eds), The White Man's Burdens: An Anthology of British Poetry of the Empire, University of Exeter Press, Exeter (1996).

Kohn, Hans, The Idea of Nationalism: A Study in Its Origins and Background, Macmillan, New York (1946).

Kornbluth, C. M., 'Two Dooms' (1958), in Frederick Pohl (ed.), The Best of C. M. Kornbluth (1976), Ballantine Books, New York (1977).

Kovel, Joel, Against the State of Nuclear Terror, Pan, London (1983).

Kureishi, Hanif, 'The Rainbow Sign', in idem, My Beautiful Laundrette and Other Writings, Faber, London (1996).

Lawson-Peebles, Robert, American Literature before 1880, Pearson and Longman, Harlow (2003).

Lefebvre, Henri, The Production of Space (1974), transl. Donald Nicholson-Smith, Blackwell, Oxford (1991).

Leghorn, Richard S., 'A Rational World Security System' (1957), in Morton Grodzins and Eugene Rabinowitch (eds), The Atomic Age: Scientists in National and World Affairs, Basic Books, New York (1963).

Lévi-Strauss, Claude, The Elementary Structures of Kinship (1949), Beacon Press, Boston (1969).

Lifton, Robert Jay, and Richard Falk, Indefensible Weapons: The Political and Psycho- 
logical Case against Nuclearism, Basic Books, New York (1982).

Limerick, Patricia Nelson, The Legacy of Conquest: The Unbroken Past of the American West, Norton, New York (1988).

Lipsitz, George, The Possessive Investment in Whiteness: How White People Profit from Identity Politics, Temple University Press, Philadelphia (1998).

London, Jack, 'The Unparalleled Invasion' (1907), in Earle Labor, Robert C. Leitz, III, and I. Milo Shepard (eds), The Complete Short Stories of Jack London (vol. II), Stanford University Press, Stanford (1993).

Lowe, Lisa, Critical Terrains: French and British Orientalisms, Cornell University Press, Ithaca, NY (1991).

Luckhurst, Roger, "Horror and Beauty in Rare Combination": The Miscegnate Fiction of Octavia Butler', Women: A Cultural Review, 7.1 (Spring 1990), pp. 2838.

MacCannell, Dean, 'Baltimore in the Morning... After: On the Forms of PostNuclear Leadership', Diacritics, 14.2 (Summer 1984), pp. 33-46.

Macdonald, Andrew, The Turner Diaries (1978), Barricade Books, Fort Lee, NJ (1996).

MacDougall, Hugh A., Racial Myth in English History, Harvest House, Montreal (1982).

Maddock, Shane J., Nuclear Apartheid: The Quest for American Atomic Supremacy from World War II to the Present, University of North Carolina Press, Chapel Hill (2010).

Mailer, Norman, 'The White Negro: Superficial Reflections on the Hipster' (1957), in idem, Advertisements for Myself (1959), Deutsch, London (1961).

Manson, Marsden, The Yellow Peril in Action: A Possible Chapter in History, Britton and Rey, San Francisco (1907).

Marable, Manning, Race, Reform, and Rebellion: The Second Reconstruction in Black America, 1945-1990 (2nd edn), University Press of Mississippi, Jackson, MS (1991).

Marshall, Paule, The Chosen Place, The Timeless People, Longman, London (1970).

Marx, Karl, Capital (vol. I), transl. Ben Fowkes, Penguin and New Left Review, Harmondsworth (1976).

Masters, Dexter, The Accident (1955), Panther, London (1960).

Mathur, Piyush, 'Nuclearism: The Contours of a Political Ecology', Social Text, 19.1 (Spring 2001), pp. 1-18.

Matsunaga, Kyoko, 'Post-Apocalyptic Vision and Survivance: Nuclear Writings in Native America and Japan', PhD Dissertation, University of Nebraska-Lincoln (2006).

May, Ernest R., and Philip D. Zelikow (eds), The Kennedy Tapes: Inside the White House during the Cuban Missile Crisis, Belknap Press and Harvard University Press, Cambridge, MA (1997).

McClintock, Anne, 'Maidens, Maps, and Mines: The Reinvention of Patriarchy in Colonial South Africa', South Atlantic Quarterly, 87.1 (Winter 1988), pp. 147-92.

—, 'The Angel of Progress: Pitfalls of the Term "Post-Colonialism"', Social Text, 10.2 (1992), pp. 84-98.

McConachie, Bruce, American Theater in the Culture of the Cold War, University of Iowa City, Iowa City (2003).

McFarlane, Brian, Australian Cinema 1970-1985, Secker \& Warburg, London (1987).

Melville, Herman, Moby Dick (1851), Wordsworth Editions, Ware (1992).

Metcalf, Barbara D., and Thomas R. Metcalf, A Concise History of India, Cambridge University Press, Cambridge (2002).

Miller, Arthur, Death of a Salesman (1949), Penguin, New York (1976). 
Miller, Walter M., Jr, A Canticle for Leibowitz (1959), Orbit and Time Warner, London (1993).

-, 'Introduction', in Walter M. Miller, Jr and Martin H. Greenberg (eds), Beyond Armageddon, University of Nebraska Press, Lincoln, NE (2006).

Minear, Richard H., Dr. Seuss Goes to War, The New Press, New York (1999).

Moore, Ward, 'Lot' (1953), in Walter M. Miller, Jr and Martin H. Greenberg (eds), Beyond Armageddon, University of Nebraska Press, Lincoln, NE (2006).

—, 'Lot's Wife' (1954), in Robert P. Mills (ed.), A Decade of Fantasy and Science Fiction, Doubleday, Garden City, NY (1960).

Morgan, Iwan, Nixon, Arnold, London (2002).

Morrison, Toni, Playing in the Dark: Whiteness and the Literary Imagination, Harvard University Press, Cambridge, MA (1992).

Mosley, Walter, 'Black to the Future', in Sheree Thomas (ed.), Dark Matter: A Century of Speculative Fiction from the African Diaspora, Aspect and Time Warner, New York (2000).

Mosse, George L., Towards the Final Solution: A History of European Racism, Dent, London (1978).

Moylan, Tom, Scraps of the Untainted Sky: Science Fiction, Utopia, Dystopia, Westview Press, Oxford (2000).

Muller, Julius W., The Invasion of America, E. P. Dutton, New York (1916).

Nadel, Alan, Containment Culture: American Narratives, Postmodernism, and the Atomic Age, Duke University Press, Durham (1995).

-, 'A Whole New (Disney) World Order: Aladdin, Atomic Power, and the Muslim Middle East', in Matthew Bernstein and Gaylyn Studlar (eds), Visions of the East: Orientalism on Film, Rutgers University Press, New Brunswick, NJ (1997).

Nama, Adilifu, Black Space: Imagining Race in Science Fiction Film, University of Texas Press, Austin (2008).

Nelson, Alondra, 'Introduction: Future Texts', Social Text, 20.2 (Summer 2002), pp. $1-15$.

Nelson, William Javier, 'Racial Definition: Background for Divergence', Phylon, 47.4 (1986), pp. 318-26.

Newman, Kim, Apocalypse Movies: End of the World Cinema, St Martin's Griffin, New York (1999).

Nordau, Max, Degeneration (1892), University of Nebraska Press, Lincoln, NE (1993).

Norton, Roy, The Vanishing Fleets, D. Appleton, New York (1908).

Nowlan, Philip Francis, Armageddon 2419 A.D., Ace, New York (1962).

Nye, Robert A., The Origins of Crowd Psychology: Gustave LeBon and the Crisis of Mass Democracy in the Third Republic, Sage, London (1975).

O'Connor, John E., 'The White Man's Indian: An Institutional Approach', in Peter C. Rollins and John E. O'Connor (eds), Hollywood's Indian: The Portrayal of the Native American in Film, University Press of Kentucky, Lexington, KY (1998).

Odell, Samuel W., The Last War; or, Triumph of the English Tongue: A Story of the TwentySixth Century Compiled from the Official Notes of Newman, Reporter to the President of United America, Charles H. Kerr and Company, Chicago (1898).

O'Regan, Tom, Australian National Cinema, Routledge, London (1996).

Oropeza, Lorena, 'Antiwar Aztlán: The Chicano Movement Opposes U.S. Intervention in Vietnam', in Brenda Gayle Plummer (ed.), Window on Freedom: Race, Civil Rights, and Foreign Affairs 1945-1988, University of North Carolina Press, Chapel Hill (2003).

Overy, Richard, 'Introduction', in Sebastian Cox and Peter Gray (eds), Air Power 
History: Turning Points from Kitty Hawk to Kosovo, Frank Cass, London (2002).

Pape, Robert A., Bombing to Win: Air Power and Coercion in War, Cornell University Press, Ithaca, NY (1996).

Parrinder, Patrick, 'The Black Wave: Science and Social Consciousness in Modern SF' (1977), CritiFan, 2 (1979), pp. 16-51.

Pearson, Karl, Francis Galton, 1822-1922: A Centenary Appreciation, Cambridge University Press, London (1922).

Percival, Melissa, The Appearance of Character: Physiognomy and Facial Expression in Eighteenth-Century France, Maney, London (1999).

Perrine, Toni A., Film and the Nuclear Age: Representing Cultural Anxiety, Garland, New York (1998).

Pick, Daniel, Faces of Degeneration: A European Disorder, c.1848-c.1918, Cambridge University Press, Cambridge (1989).

- War Machine: The Rationalisation of Slaughter in the Modern Age, Yale University Press, New Haven (1993).

Piercy, Marge, Body of Glass (original title He, She and It), Penguin, Harmondsworth (1992).

Piette, Adam, The Literary Cold War, 1945 to Vietnam, Edinburgh University Press, Edinburgh (2009).

Plummer, Brenda Gayle, 'Castro in Harlem: A Cold War Watershed', in Allen Hunter (ed.), Rethinking the Cold War, Temple University Press, Philadelphia (1998).

-, 'Introduction', in idem (ed.), Window on Freedom: Race, Civil Rights, and Foreign Affairs 1945-1988, University of North Carolina Press, Chapel Hill (2003).

Powell, J. M., 'Conservation and Resource Management in Australia 1788-1860', in J. M. Powell and M. Williams (eds), Australian Space, Australian Time: Geographical Perspectives, Oxford University Press, Oxford (1975).

Preston, John, 'Protect and Survive: "Whiteness" and the Middle-Class Family in Civil Defence Pedagogies', Journal of Education Policy, 23.5 (Sept. 2008), pp. 46982.

Rabkin, Eric S., 'Introduction: Why Destroy the World?', in Eric S. Rabkin, Martin H. Greenberg and Joseph D. Olander (eds), The End of the World, Southern Illinois University Press, Carbondale (1983).

Rafael, Vincente L., 'White Love: Surveillance and Resistance in the US Colonization of the Philippines', in Amy Kaplan and Donald Pease (eds), Cultures of United States Imperialism, Duke University Press, Durham (1993).

Rajghatta, Chidanand, 'The Hindu Bomb', The Indian Express (21 May 1998), http:// Www.indianexpress.com/ie/daily/19980521/14150864.html (last accessed Apr. 2011).

Rawlinson, Mark, British Writing of the Second World War, Clarendon Press and Oxford University Press, Oxford (2000).

Rayner, Jonathan, Contemporary Australian Cinema: An Introduction, Manchester University Press, Manchester (2000).

Reed, Ishmael, Mumbo Jumbo, Doubleday, Garden City, NY (1972).

Reed, Ishmael, Shawn Wong, Bob Callaghan et al., 'Is Ethnicity Obsolete?', in Werner Sollors (ed.), The Invention of Ethnicity, Oxford University Press, New York (1989).

Reed, Peter J., Kurt Vonnegut, Jr., Warner Paperback Library, New York (1972).

Reed, Samuel Rockwell, The War of 1886, Between the United States and Great Britain, Cincinnati (1882).

Renan, Ernest, 'What Is a Nation?' (1882), transl. Martin Thom, in Homi K. Bhabha 
(ed.), Nation and Narration, Routledge, London (1990).

Richards, Leo, 'Where Are Your Worshippers', Voices (Winter 1950), p. 21.

Rieder, John, Colonialism and the Emergence of Science Fiction, Wesleyan University Press, Middletown, CT (2008).

Ringer, Gerald J., 'The Bomb as a Living Symbol: An Interpretation', PhD Dissertation, Florida State University (1966).

Robinson, Kim Stanley, The Wild Shore, Ace, New York (1984).

Roediger, David R., The Wages of Whiteness: Race and the Making of the American Working Class, Verso, London (1991).

Rogin, Michael Paul, Ronald Reagan, the Movie, University of California Press, Berkeley (1987).

Rose, Wendy, 'Robert', in idem, The Halfbreed Chronicles and Other Poems, West End Press, Los Angeles (1985).

Roshwald, Mordecai, Level 7, Signet Books, New York (1959).

Rotter, Andrew J., Hiroshima: The World's Bomb, Oxford University Press, Oxford (2008).

Rowlandson, Mary, A Narrative of the Captivity and Restoration of Mrs. Mary Rowlandson (1682), in Nina Baym (gen. ed.), The Norton Anthology of American Literature (6th edn, vol. A), Norton, New York (2003).

Roy, Arundhati, The Algebra of Infinite Justice, Flamingo, London (2002).

-, The Ordinary Person's Guide to Empire, Flamingo, London (2004).

Rushdie, Salman, The Moor's Last Sigh (1995), Vintage, New York (1997).

Russell, Bertrand, 'The Case for British Nuclear Disarmament' (1962), in Morton Grodzins and Eugene Rabinowitch (eds), The Atomic Age: Scientists in National and World Affairs, Basic Books, New York (1963).

Said, Edward W., Orientalism (rev. edn), Penguin, Harmondsworth (1995).

Schaub, Thomas H., American Fiction in the Cold War, University of Wisconsin Press, Madison (1991).

Scheick, William J., 'Nuclear Criticism: An Introduction', PLL: Papers on Language e Literature, 26.1 (Winter 1990), pp. 3-12.

Schell, Jonathon, The Fate of the Earth, Avon, New York (1982).

Schwartz, Richard A., 'Family, Gender, and Society in 1950s American Fiction of Nuclear Apocalypse: Shadow on the Hearth, Tomorrow!, The Last Day, and Alas, Babylon', Journal of American Culture, 29.4 (Dec. 2006), pp. 406-24.

Scott, Jonathan, 'Octavia Butler and the Base for American Socialism', Socialism and Democracy, 20.3 (Nov. 2006), pp. 105-26.

Scruton, Roger, The Meaning of Conservatism, Penguin, Harmondsworth (1980).

Seed, David, American Science Fiction and the Cold War: Literature and Film, Edinburgh University Press, Edinburgh (1999).

—, 'H. G. Wells and the Liberating Atom', Science Fiction Studies, 30 (2003), pp. $33-$ 48.

_, 'Mapping the Post-Nuclear Landscape', Foundation, 89 (Autumn 2003), pp. 6576.

-, 'Constructing America's Enemies: The Invasions of the USA', Yearbook of English Studies, 37.2 (2007), pp. 64-84.

Senior, Olive, 'rain' (1985), in E. A. Markham (ed.), Hinterland: Caribbean Poetry from the West Indies e Britain (2nd edn), Bloodaxe, Newcastle-upon-Tyne (1995).

Shaheen, Jack G. (ed.), Nuclear War Films, Southern Illinois University Press, Carbondale (1978).

Shakespeare, William, The Tempest (1610-11), ed. Virginia Mason Vaughan and Alden T. Vaughan (for the Arden Shakespeare third series), Thomas Nelson and 
Sons, Walton-on-Thames, Surrey (1999).

Shapiro, Jerome F., Atomic Bomb Cinema, Routledge, New York (2002).

Sharp, Patrick B., 'The White Man's Bomb: Race and Nuclear Apocalypse Narrative in American Culture', PhD Dissertation, University of California (1999).

-, Savage Perils: Racial Frontiers and Nuclear Apocalypse in American Culture, University of Oklahoma Press, Norman, OK (2007).

Shaw, Tony, British Cinema and the Cold War (2001), I. B. Tauris, London (2006).

—, Hollywood's Cold War, Edinburgh University Press, Edinburgh (2007).

Sheckels, Theodore F., Celluloid Heroes Down Under: Australian Film, 1970-2000, Praeger, Westport, CT (2002).

Shelley, Percy Bysshe, 'Mont Blanc' (1816), in Neville Rogers (ed.), The Complete Poetic Works of Percy Bysshe Shelley (vol. II), Clarendon Press, Oxford (1975).

Sherriff, R. C., The Hopkins Manuscript, Victor Gollancz, London (1939).

Shiel, M. P., The Yellow Danger, Grant Richards, London (1898).

Shocklee, Keith, Eric Sadler and Carlton Ridenhour, 'Fear of a Black Planet', in Public Enemy, Fear of a Black Planet, Def Jam Recordings, New York (1990).

Shohat, Ella, 'Imagining Terra Incognita: The Disciplinary Gaze of Empire', Public Culture, 3.2 (Spring 1991), pp. 41-70.

Shohat, Ella, and Robert Stam, Unthinking Eurocentrism: Multiculturalism and the Media, Routledge, London (1994).

Shute, Nevil, On the Beach, Heinemann, London (1957).

Siegel, Barbara and Scott Siegel, Firebrats \#1: The Burning Land, Archway, New York (1987).

—, Firebrats \#2: Survivors, Archway, New York (1987).

—, Firebrats \#3: Thunder Mountain, Archway, New York (1987).

- Firebrats \#4: Shockwave, Archway, New York (1988).

Silko, Leslie Marmon, Ceremony (1977), Penguin, Harmondsworth (1986).

Sinker, Mark, 'Loving the Alien' (1992), The Wire, http://www.thewire.co.uk/ articles/218/ (last accessed Aug. 2010).

Smedley, Audrey, 'American Anthropological Association Statement on "Race"' (17 May 1998), American Anthropological Association, http://www.aaanet.org/ stmts/racepp.htm (last accessed Aug. 2010).

Smetak, Jacqueline R., 'Sex and Death in Nuclear Holocaust Literature of the 1950s', in Nancy Anisfield (ed.), The Nightmare Considered: Critical Essays on Nuclear War Literature, Bowling Green State University Popular Press, Bowling Green, OH (1991).

Smith, Barbara, "Fractious, Kicking, Messy, Free": Feminist Writers Confront the Nuclear Abyss', in Jim Schley (ed.), Writing in a Nuclear Age (1983), University Press of New England, Hanover (1984).

—, 'Introduction', in idem (ed.), Home Girls: A Black Feminist Anthology (2nd edn), Rutgers University Press, New Brunswick, NJ (2000).

Smith, Darryl A., 'Droppin' Science Signification and Singularity in the Metapocalypse of Du Bois, Baraka, and Bell', Science Fiction Studies, 34.2 (July 2007), pp. 201-19.

Smith, Martin Cruz, Stallion Gate (1986), Pan, London (1987).

Smith, Shawn Michelle, "Baby's Picture Is Always Treasured": Eugenics and the Reproduction of Whiteness in the Family Photograph Album' (1999), in Vanessa R. Schwartz and Jeannene M. Przyblyski (eds), The Nineteenth-Century Visual Culture Reader, Routledge, New York (2004).

Snead, James, White Screens / Black Images: Hollywood from the Dark Side, ed. Colin McCabe and Cornell West, Routledge, New York (1994). 
Sollors, Werner, Beyond Ethnicity: Consent and Descent in American Culture, Oxford University Press, New York (1986).

-, 'Introduction: The Invention of Ethnicity', in idem (ed.), The Invention of Ethnicity, Oxford University Press, New York (1989).

-, 'Ethnicity', in Frank Lentricchia and Thomas McLaughlin (eds), Critical Terms for Literary Study (2nd edn), University of Chicago Press, Chicago (1995).

-, 'Foreword: Theories of American Ethnicity', in idem (ed.), Theories of Ethnicity: A Classical Reader, New York University Press, New York (1996).

- Neither Black nor White Yet Both: Thematic Explorations of Interracial Literature, Harvard University Press, Cambridge, MA (1999).

Solomon, J. Fisher, Discourse and Reference in the Nuclear Age, University of Oklahoma Press, Norman, OK (1988).

Spinrad, Norman, 'The Big Flash' (1969), in Walter M. Miller, Jr and Martin H. Greenberg (eds), Beyond Armageddon, University of Nebraska Press, Lincoln, NE (2006).

Stableford, Brian, 'Man-Made Catastrophes', in Eric S. Rabkin, Martin H. Greenberg and Joseph D. Olander (eds), The End of the World, Southern Illinois University Press, Carbondale (1983).

Stockton, Frank, The Great War Syndicate, New York (1889).

Stone, Albert E., Literary Aftershocks: American Writers, Readers, and the Bomb, Twayne, New York (1994).

Strieber, Whitley, Wolf of Shadows, Knopf, New York (1985).

Strieber, Whitley, and David W. Kunetka, Warday and the Journey Onward (1984), Coronet and Hodder and Stoughton, Sevenoaks, Kent (1985).

Sullivan, C. W., III, 'Alas, Babylon and On the Beach: Antiphons of the Apocalypse', in Carl B. Yoke (ed.), Phoenix from the Ashes: The Literature of the Remade World, Greenwood Press, Westport, CT (1987).

Swanwick, Michael, 'The Feast of Saint Janis' (1980), in Walter M. Miller, Jr and Martin H. Greenberg (eds), Beyond Armageddon, University of Nebraska Press, Lincoln, NE (2006).

Swarmy, Arun R., 'Ideology, Organization and Electoral Strategy of Hindu Nationalism: What's Religion Got to Do with It?', in Satu P. Limaye, Mohan Malik and Robert G. Wirsing (eds), Religious Radicalism and Security in South Asia, Asia-Pacific Center for Security Studies, Honolulu (2004).

Szilard, Leo, 'Atomic Bombs and the Postwar Position of the United States in the World' (1945), in Morton Grodzins and Eugene Rabinowitch (eds), The Atomic Age: Scientists in National and World Affairs, Basic Books, New York (1963).

Talbott, Strobe, Engaging India: Diplomacy, Democracy, and the Bomb, Brookings Institution Press, Washington, DC (2004).

Tenn, William, 'Eastward Ho!' (1958), in Walter M. Miller, Jr and Martin H. Greenberg (eds), Beyond Armageddon, University of Nebraska Press, Lincoln, NE (2006).

Thorpe, Charles, Oppenheimer: The Tragic Intellect, The University of Chicago Press, Chicago (2006).

Turner, Frederick, Beyond Geography: The Western Spirit against the Wilderness, Rutgers University Press, New Brunswick, NJ (1983).

Turner, Frederick Jackson, 'The Significance of the Frontier in American History' (1893), in Martin Ridge (ed.), Frederick Jackson Turner: Wisconsin's Historian of the Frontier, Wisconsin State Historical Society, Madison (1986).

Vienna Declaration, The (1958), in Morton Grodzins and Eugene Rabinowitch (eds), The Atomic Age: Scientists in National and World Affairs, Basic Books, New York (1963). 
Vint, Sherryl, “'Only by Experience": Embodiment and the Limitations of Realism in Neo-Slave Narratives', Science Fiction Studies, 34.2 (July 2007), pp. 241-61.

Vonnegut, Kurt, Jr, Cat's Cradle (1963), Penguin, Harmondsworth (1965).

Wachhorst, Wyn, 'The Days After: Films on Nuclear Aftermath', in Carl B. Yoke (ed.), Phoenix from the Ashes: The Literature of the Remade World, Greenwood Press, Westport, CT (1987).

Waddington, C. H., 'Scientific and Technological Cooperation: A Key to Mutual Trust' (1958), in Morton Grodzins and Eugene Rabinowitch (eds), The Atomic Age: Scientists in National and World Affairs, Basic Books, New York (1963).

Wagar, W. Warren, Terminal Visions: The Literature of Last Things, Indiana University Press, Bloomington (1982).

-, 'The Rebellion of Nature', in Eric S. Rabkin, Martin H. Greenberg and Joseph D. Olander (eds), The End of the World, Southern Illinois University Press, Carbondale (1983).

Walcott, Derek, 'The Muse of History', in Orde Coombs (ed.), Is Massa Day Dead? Black Moods in the Caribbean, Anchor and Doubleday, Garden City, NY (1974).

Waldrop, Howard, Them Bones, Century Hutchinson, London (1989).

Walker, Alice, 'Only Justice Can Stop a Curse' (1982), in Barbara Smith (ed.), Home Girls: A Black Feminist Anthology (2nd edn), Rutgers University Press, New Brunswick, NJ (2000).

Walker, Brian, 'The War Made a Realist Out of $\mathrm{Me}^{\prime}$, in Alex Raymond and Ward Greene, Rip Kirby (vol. I), Library of American Comics and IDW Publishing, San Diego (2009).

Wallis, Brian, 'Black Bodies, White Science: Louis Agassiz's Slave Daguerreotypes', American Art, 9.2 (Summer 1995), pp. 38-61.

Ware, Chris, Jimmy Corrigan: The Smartest Kid on Earth, Pantheon, New York (2000).

Weart, Spencer R., Nuclear Fear: A History of Images, Harvard University Press, Cambridge, MA (1988).

Weinberg, Alvin M., 'Prospects in International Science' (1958), in Morton Grodzins and Eugene Rabinowitch (eds), The Atomic Age: Scientists in National and World Affairs, Basic Books, New York (1963).

Wells, H. G., The War of the Worlds (1898), J. M. Dent, London (1993).

-, The World Set Free: A Story of Mankind, Macmillan, London (1914).

West, Morris, The Shoes of the Fisherman, Heinemann, London (1963).

White, Arnold, Efficiency and Empire, Methuen, London (1901).

Whitfield, Stephen J., The Culture of the Cold War, The John Hopkins University Press, Baltimore, MD (1991).

Whitney, Atwell, Almond-Eyed: A Story of the Day, A. L. Bancroft, San Francisco (1878).

Williams, John A., Captain Blackman (1972), Thunder's Mouth Press, New York (1988).

Williams, Paul, 'Nuclear Criticism', in Mark Bould, Andrew M. Butler, Adam Roberts and Sherryl Vint (eds), The Routledge Companion to Science Fiction, Routledge, Abingdon (2009).

Williams, Raymond, Keywords: A Vocabulary of Culture and Society (new edn), Fontana Press, London (1988).

Wilson, Steve, The Lost Traveller, Macmillan, London (1976).

Winkler, Allan M., Life under a Cloud: American Anxiety about the Atom, Oxford University Press, New York (1993).

Wodehouse, P. G., The Swoop!: or, How Clarence Saved England: A Tale of the Great Invasion, Alston Rivers, London (1909). 
Wolfe, Bernard, Limbo, Random House, New York (1952).

Wolfe, Gary K., 'The Remaking of Zero: Beginning at the End', in Eric S. Rabkin, Martin H. Greenberg and Joseph D. Olander (eds), The End of the World, Southern Illinois University Press, Carbondale (1983).

Wylie, Philip, Tomorrow! (1954), University of Nebraska Press, Lincoln, NE (2009).

—, Triumph (1963), University of Nebraska Press, Lincoln, NE (2007).

X, Malcolm, with the assistance of Alex Haley, The Autobiography of Malcolm X (1965), Penguin, London (2001).

Yost, David S., The US and Nuclear Deterrence in Europe, Oxford University Press and International Institute for Strategic Studies, Oxford (1999).

Young Bear, Ray A., 'A Drive to Lone Ranger', in John Witte (ed.), Warnings: An Anthology on the Nuclear Peril, Northwest Review, Eugene, OR (1984).

Zangwill, Israel, The Melting-Pot, Macmillan, New York (1909).

Zinn, Howard, A People's History of the United States, Longman, London (1980).

Zins, Daniel L., 'Rescuing Science from Technocracy: Cat's Cradle and the Play of Apocalypse', Science Fiction Studies, 13.2 (July 1986), pp. 170-81.

-, 'Exploding the Canon: Nuclear Criticism in the English Department', PLL:Papers on Language $\theta$ Literature, 26.1 (Winter 1990), pp. 13-40.

Žižek, Slavoj, 'The Depraved Heroes of 24 are the Himmlers of Hollywood', Guardian (10 Jan. 2006), http://www.guardian.co.uk/comment/story/ 0,3604, 1682760,00.html (last accessed June 2007).

\section{Filmography}

Atomic Train (Trimark, 1999) Dir. David Jackson and Dick Lowry; Prod. Michael R. Joyce; Dir. of Photo. Steven Fierberg; Sc. D. Brent Mote, Phil Penningroth and Rob Fresco; starring Rob Lowe, Kristin Davis, Esai Morales, John Finn and Mena Suvari.

Birth of a Nation (Epoch Producing, David W. Griffith Corporation, 1915) Dir. D. W. Griffith; Prod. D. W. Griffith and Harry E. Aitken; Dir. of Photo. Billy Bitzer; Sc. D. W. Griffith and Frank E. Woods; starring Henry B. Walthall, Mae Marsh, Violet Wilkey, Miriam Cooper and Josephine Crowell.

Cherry 2000 (Orion Pictures, 1987) Dir. Steve De Jarnatt; Prod. Edward R. Pressman and Caldecot Chubb; Dir. of Photo. Jacques Haitkin; Sc. Michael Almereyda; starring Melanie Griffith, David Andrews and Ben Johnson.

Crocodile Dundee (Rimfire Films, 1986) Dir. Peter Faiman; Prod. John Cornell; Dir. of Photo. Russell Boyd; Sc. Paul Hogan, Ken Shadie and John Cornell; starring Paul Hogan, Linda Kozlowski, John Meillon and David Gulpilil.

Cruise Missile (also known as Missile X-Geheimauftrag Neutronenbombe) (Eichberg Film, Cinelux-Romano Film, Cineluce, Mundial Films, Noble, 1979) Dir. Leslie H. Martinson; Prod. Ika Panajotovic; Dir. of Photo. Claudio Catozzo; Sc. Clarke Reynolds and Elio Romano; starring Peter Graves and Curd Jürgens.

Day the World Ended (Golden State and ARC, 1956) Dir. Roger Corman; Prod. Roger Corman; Dir. of Photo. Jock Feindel; Sc. Lou Rusoff; starring Richard Denning, Lori Nelson, Adele Jergens, Mike Connors and Paul Birch.

Def-Con 4 (New World, Salter Street Films, Dark Eye Film, 1984) Dir. Paul Donovan; Prod. Michael Donovan, Paul Donovan and Maura O'Connell; Dir. of Photo. Douglas Connell and Les Krizsan; Sc. Paul Donovan; starring Lenore Zann, Maury Chaykin, Kate Lynch and Kevin King.

Destination Moon (George Pal Productions, 1950) Dir. Irving Pichel; Prod. George Pal; Dir. of Photo. Lionel Linden; Sc. Rip Van Ronkel, R. A. Heinlein and James 
O'Hanlon; starring John Archer, Warner Anderson, Tom Powers, Dick Wesson and Erin O'Brien-Moore.

Deterrence (Moonstone Entertainment, TF1 International, Battleplan, 1999) Dir. Rod Lurie; Prod. Marc Frydman and James Spies; Dir. of Photo. Frank Perl; Sc. Rod Lurie; starring Kevin Pollak, Timothy Hutton and Sheryl Lee Ralph.

Fail Safe (Sidney Lumet Productions, Columbia Pictures, 1964) Dir. Sidney Lumet; Prod. Max E. Youngstein; Dir. of Photo. Gerald Hirschfeld; Sc. Walter Bernstein; starring Dan O'Herlihy, Walter Matthau, Frank Overton, Ed Binns and Henry Fonda.

Five (Columbia, 1951) Dir. Arch Oboler; Prod. Arch Oboler; Photo. Ed Spiegel, Louis Clyde Stoumen and Arthur L. Swerdloff; Sc. Arch Oboler; starring William Phipps, Susan Douglas, James Anderson, Charles Lampkin and Earl Lee.

Frantic (Mount Company, Warner Brothers, 1988) Dir. Roman Polanski; Prod. Thom Mount and Tim Hampton; Dir. of Photo. Witold Sobocinski; Sc. Roman Polanski and Gérard Brach; starring Harrison Ford, Betty Buckley, John Mahoney, Jimmie Ray Weels and Yorgo Voyagis.

Invaders from Mars (Edward L. Alperson Productions, 1953) Dir. William Cameron Menzies; Prod. Edward L. Alperson; Dir. of Photo. John F. Seitz; Sc. Richard Blake; starring Helena Carter, Arthur Franz and Jimmy Hunt.

King Kong (RKO Radio Pictures, 1933) Dir. Merian C. Cooper and Ernest B. Schoedsack; Prod. Merian C. Cooper and Ernest B. Schoedsack; Cine. Eddie Linden, J. O. Taylor and Vernon Walker; Sc. James Ashmore Creelman and Ruth Rose; starring Fay Wray, Robert Armstrong, Bruce Cabot and Frank Reicher.

Mad Max (Mad Max, 1979) Dir. George Miller; Prod. Byron Kennedy; Cine. David Eggby; Sc. George Miller and James McCausland; starring Mel Gibson, Joanne Samuel, Hugh Keays-Byrne, Steve Bisley and Tim Burns.

Mad Max II (also known as The Road Warrior) (Kennedy Miller Productions, 1981) Dir. George Miller; Prod. Byron Kennedy; Cine. Dean Semler; Sc. Terry Hayes, George Miller and Brian Hannant; starring Mel Gibson, Bruce Spence, Mike Preston, Max Phipps and Vernon Wells.

Mad Max Beyond Thunderdome (also known as Mad Max III) (Kennedy Miller Productions, 1985) Dir. George Ogilvie and George Miller; Prod. George Miller; Dir. of Photo. Dean Semler; Sc. Terry Hayes and George Miller; starring Mel Gibson, Tina Turner, Bruce Spence, Angelo Rossitto and Helen Buday.

The Mouse That Roared (Open Road Films, 1959) Dir. Jack Arnold; Prod. Carl Foreman, Jon Penington and Walter Shenson; Dir. of Photo. John Wilcox; Sc. Roger MacDougall and Stanley Mann; starring Peter Sellers, Jean Seberg, William Hartnell, David Kossoff and Leo McKern.

Neon City (Neon Productions, 1992) Dir. Monte Markham; Prod. Wolf Schmidt; Sc. Buck Finch, Jeff Begun and Monte Markham; starring Michael Ironside, Vanity, Lyle Alzado, Lee Purcell and Richard Sanders.

On the Beach (Lomitas Productions, 1959) Dir. Stanley Kramer; Prod. Stanley Kramer; Photo. Giuseppe Rotunno; Sc. John Paxton; starring Gregory Peck, Ava Gardner, Fred Astaire, Anthony Perkins and Donna Anderson.

The Peacemaker (DreamWorks SKG, 1997) Dir. Mimi Leder; Prod. Walter Parkes and Branko Lustig; Dir. of Photo. Dietrich Lohmann; Sc. Michael Schiffer; starring George Clooney and Nicole Kidman.

Red Dawn (United Artists, Valkyrie Productions, Sidney Beckerman Productions, 1984) Dir. John Milius; Prod. Barry Beckerman and Buzz Feitshans; Dir. of Photo. Ric Waite; Sc. John Milius and Kevin Reynolds; starring Patrick Swayze, C. Thomas Howell, Lea Thompson and Charlie Sheen. 
The Shoes of the Fisherman (MGM, George Englund Enterprises, 1968) Dir. Michael Anderson; Prod. George Englund; Dir. of Photo. Erwin Hillier; Sc. James Kennaway and John Patrick; starring Anthony Quinn, Laurence Olivier, Oskar Werner, David Janssen and Vittorio De Sica.

Studio 64: The Crunch (ATV, 1964) Dir. Michael Elliott; Prod. Stuart Burge; Sc. Nigel Kneale; starring Harry Andrews, Maxwell Shaw, Wolfe Morris, Anthony Bushell and Peter Bowles.

Tank Girl (Trilogy, United Artists, 1995) Dir. Rachel Talalay; Prod. Pen Densham, Richard Barton Lewis and John Watson; Dir. of Photo. Gale Tattersall; Sc. Tedi Sarafian; starring Lori Petty, Ice-T, Naomi Watts and Don Harvey.

Threads (BBC, Network 9, Western World TV, 1984) Dir. Mick Jackson; Prod. Mick Jackson; Photo. Andrew Dunn and Paul Morris; Sc. Barry Hines; starring Karen Meagher, Reece Dinsdale and David Brierly.

Tomorrow Never Dies (Danjaq LLC, United Artists, Eon, United Artists, MGM, 1997) Dir. Roger Spottiswoode; Prod. Barbara Broccoli and Michael G. Wilson; Dir. of Photo. Robert Elswit; Sc. Bruce Feirstein; starring Pierce Brosnan, Jonathan Pryce, Michelle Yeoh, Teri Hatcher and Ricky Jay.

True Lies (Lightstorm Entertainment, Twentieth Century Fox, 1994) Dir. James Cameron; Prod. Stephanie Austin and James Cameron; Dir. of Photo. Russell Carpenter; Sc. James Cameron; starring Arnold Schwarzenegger, Jamie Lee Curtis, Tom Arnold, Bill Paxton and Tia Carrere.

Until the End of the World (also known as Bis ans Ende der Welt) (Australian Film Finance, Road Movies, Argos-Films, Village Roadshow, Phanos Development, CNC, Région Languedoc-Roussillon, 1991) Dir. Wim Wenders; Prod. Anatole Dauman, Paolo Branco and Jonathan T. Taplin; Dir. of Photo. Robby Müller; Sc. Michael Almereyda, Peter Carey and Wim Wenders; starring Solveig Dommartin, William Hurt, Sam Neill and Max von Sydow.

Victory through Air Power (Walt Disney Productions, 1943) Dr. H. C. Potter, Clyde Geronimi, Jack Kinney and James Algar; Prod. not attributed; Dir. of Photo. Ray Rennahan; Story Adapt. T. Hee, Erdman Penner, William Cottrell, Jim Bodrero, George Stallings and José Rodriguez; starring Major Alexander P. de Seversky and Art Baker.

Walkabout (Max L. Raab and Si Litvinoff Films, 1970) Dir. Nicolas Roeg; Prod. Si Litvinoff; Dir. of Photo. Nicolas Roeg; Sc. Edward Bond; starring Jenny Agutter, Lucien John, David Gumpilil and John Meillon.

World Gone Wild (Apollo Pictures, World Gone Wild, 1988) Dir. Lee H. Katzin; Prod. Robert L. Rosen; Dir. of Photo. Don Burgess; Sc. Jorge Zamacona; starring Bruce Dern, Catherine Mary Stewart, Michael Paré and Adam Ant.

The World, the Flesh, and the Devil (Sol C. Siegel Productions, HarBel, 1959) Dir. Ranald MacDougall; Prod. George Englund; Dir. of Photo. Harold J. Marzorati; Sc. Ranald MacDougall; starring Harry Belafonte, Inger Stevens and Mel Ferrer.

\section{Television Series and Documentaries}

Dirty War. Dir. Daniel Percival. Prod. Luke Alvin. BBC 1. 26 Sept. 2004.

To Mars by A-Bomb: The Secret History of Project Orion. Dir. not attributed. Prod. Christopher Sykes. BBC 2. 12 Nov. 2003.

24. Dir. Stephen Hopkins, Winrich Kolbe and Bryan Spicer et al.; Prod. Cyrus Yavneh and Andrea Newman et al.; starring Kiefer Sutherland, Elisha Cuthbert, Dennis Haysbert and Mary Lynn Rajskub. Fox Television Network. 6 Nov. 2001-24 May 2010. 


\section{Index}

Abbott, Carl: 'Homesteading on the Extraterrestrial Frontier' 51

Achebe, Chinua 64

activism, anti-nuclear 165-6, 168, 173

Adorno, Theodor 180, 186, 195

Advani, L. K. 206, 207, 209

aerial warfare $38-42,44$

Africa 157, 162, 169

African-Americans

aerial attacks on 40-1

authors 5, 135

empathy 148-9

endurance 160-1

freedom 147

identities 12-13

invisibility 123

Manhattan Project 181

mistreatment 152

nuclear attack victims 112, 113, 154

racial difference $115,116-17$

racial tension $132-4$

segregation 159-62, 166

slavery 172

stereotypes 149

violence towards 149,150

The World, The Flesh and the Devil (film) 120-5

and World Peace Appeal 171

African diaspora 151, 162

Africans 64

Ahern, Jerry: Survivalist series 51

Aladdin (film) 244

Albania 226

America see United States

American Anthropological Society 187

American Civil War 29 see also The Birth of a Nation (film)

American Dream 155

American Indian Movement 55

Americanness 132, 197

Ames, Nathaniel 72-3

Anderson, Benedict: Imagined Communities 14

Anderson, James 125

Anderson, Poul: 'Tomorrow's Children' 52

antagonistic acculturation 217

antinuclear politics 168-75

Antipodes 89

anti-Semitism

Nazis 27, 28

Stallion Gate (Smith) 182, 190

United States 181, 183-9
Appiah, Kwame Anthony 10

architecture 126, 132

Aryans 27-8, 99

Asians

fear of 30-1, 33-4, 37, 42

see also Chinese; India; Japan; Pakistan

Assembly of the Greater East Asiatic Nations (Tokyo, 1943) 43

atomic bombs

The Accident (Masters) 187

Japan 5, 41, 44, 152, 180

'Mont Blanc' (Brathwaite) 157

shelters 159-62

threat of 225

Thunderball (Fleming) 230-1, 232

United States 180, 187 see also Manhattan Project

The World Set Free (Wells) 36

You Only Live Twice (Fleming) 231

atomic energy 85

Atomic Train (film) 242

atomic weapons 154, 157

Attridge, Derek 3-4

Australia 85-102

Aboriginal peoples 88-9, 94-5

alternative societies $87-8$

and America compared 89

civilization 90

colonial tradition $85,86,87-8,90,91-2$

colonization 96-102

desert 89-90

environment 90-1

nuclear testing 87

stereotypes 91, 92-3, 232-3

Triumph (Wylie) 129, 132

automatic weapons 29

Aztlán 61-2

Baldwin, James 107, 117, 123, 172

The Fire Next Time 149-50, 155-6, 168-9

Balibar, Etienne 14-15

Barnes, Julian: A History of the World in 101/2 Chapters 85, 244

Barton, Samuel: The Battle of the Swash; and The Capture of Canada 30

Beauvoir, Simone de 147

Belafonte, Harry 120, 124

Benjamin, Walter 235, 236

Berlin Crisis 162

Berlin Wall 217

Bewley-Taylor, David R. 73 
Bhabha, Homi Jehangir 212

Bhagavad Gita 202-3

Bilbo, Senator Theodore 105

The Birth of a Nation (film) 37

black feminism 171

black rain 153-4, 159

'blackness' 13, 105-41, 234

Blackwood's Magazine 29

Blair, Tony 245

Blamey, General Sir Thomas 42

Blavatsky, Madame 27-8

Bogle, Donald: Toms, Coons, Mulattoes, Mammies, and Bucks 123

bombs see atomic bombs; hydrogen bombs; incendiary bombs

Booker, M. Keith 50

Monsters, Mushroom Clouds, and the Cold War 7

Bourne, Randolph 127

Boyer, Paul 5, 181

By the Bomb's Early Light 8

Brackett, Leigh: The Long Tomorrow 51

Bradbury, Ray

The Martian Chronicles 80n20, 133

'The Other Foot' 132-4

Brathwaite, Edward Kamau: 'Mont Blanc' 156,157

Brennan, Timothy 14

Brians, Paul 51, 239

Nuclear Holocausts 6

Britain 39-40, 70-1, 74

British Direct Action Committee 169

British Empire 50,63

Brock, William E. 68

Broderick, Mick 51, 94, 240

Brooks, Van Wyck: 'Transnationalism' 126

Brown, Frederic and Reynolds, Mack: 'Dark Interlude' 108

Brunner, Edward: Cold War Poetry 9, 154

Bryant, Edward: 'Jody after the War' 239

Bulletin of Atomic Scientists 1 11, 165, 226

Bush, President George W. 245, 246

Butler, Octavia E.

Dawn 134-41

'The Monophobic Response' 135

Byron, George Gordon, Lord: 'Childe

Harold's Pilgrimage' 172

Bywater, Hector C.: The Great Pacific War 38

Calcutta 220

Caldicott, Helen: Missile Envy 241

Campaign for Nuclear Disarmament 169

capitalism 14-15

Carroll, Mark: Music and Ideology in Cold War Europe 9

Carter, Angela: Heroes and Villains 96

Carter, Paul: The Road to Botany Bay 89-90

Cass, Lewis 58

Castro, Fidel 232, 237

Cavalier Weekly 35
Chamberlain, Stewart Houston: Foundations of the Nineteenth Century 28

Chandhoke, Veera 210

Chandra, Vikram: Sacred Games 214-16

Chesney, Sir George Tomkyns: 'The Battle of Dorking' 29-30

Chicago Defender (newspaper) 151, 180

Chicano Movement 61-2

children

defencelessness 154

'The Feast of Saint Janis' (Swanwick) 66

Mad Max trilogy 93-4, 94-5, 99, 100-1

nuclear tests 171-2

children's literature 51, 56

China

The Last Jet-Engine Laugh (Joshi) 214

nuclear testing 87, 170, 238

Chinese, representations of

'Almond-Eyed' (Whitney) 30-1

'A Boy and his Dog' (Ellison) 238

'Jody after the War' (Bryant) 239

Red Dawn (film) 239

'The Unparalleled Invasion' (London) 345

Christianity 28, 77, 157, 207

Churchill, Winston 40

civil disobedience 174

civil rights movement 59, 169, 170

civilization

American 15, 58, 78, 107, 182

Asian 243-4

Australian 90, 95

and barbarity 180

European 15, 88, 156, 195-6

Greek 243, 244

Mad Max trilogy 98, 100

nuclear weapons 202

and oil 93

and race 42

and war 182

Western 157

Clarke, I.F. 29, 30, 51

Voices Prophesying War 6

Clarkson, Helen: The Last Day 197-8

Cloete, Stuart: 'The Blast' 56

Cohen, G. A. 138

Cold War 2

boundaries 9

civil defence planning 111-12, 159, 161-2

defence 170

literature of 9

Los Alamos (Kanon) 197

colonization, white 10-11, 212

colonized peoples: infantilization 64-5

Committee for a Sane Nuclear Policy (SANE) 170

Committee for Nonviolent Action 169

commodities: fetishization of 76

communism, fear of 189

Connor, Steven 88-9 
Conrad, Joseph: Heart of Darkness 64, 189

consumers/consumerism 14, 74

Cooper, James Fenimore: The Last of the Mohicans 56-7, 65

Cooper, Ken 151, 164

'The Whiteness of the Bomb' 8

Cordle, Daniel 106, 116-17

States of Suspense 5

Cortright, David 208

Coward, Noël 64

The Crisis (magazine) 180

Crocodile Dundee (film) 91

Cruise Missile (film) 240

The Crunch (TV film) 241

Cuban Missile Crisis (1962) 2-3, 229-30, 232

cultural differences 167

Darwin, Charles 10, 25, 52, 58

Davis, Chandler: 'Nightmare' 225

Davis, Mike 73-4

Day the World Ended (film) 77

de Seversky, Major Alexander P.: Victory through Air Power 41-2

'The Decline and Fall of the British Empire' (pamphlet) 26

Def Con 4 (film) 240

Delany, Samuel R.: The Jewels of Aptor 5

Desert Storm campaign 244

Destination Moon (film) 166

Deterrence (TV film) 244-5

difference 138-9

Dixon, Thomas

The Clansman 37

The Fall of a Nation 36-7

Donnelly, Henry Grattan: The Stricken Nation 30

Donnelly, Ignatius: Caesar's Column 32

Dooner, Pierton W.: Last Days of the Republic 31

Douglass, Frederick

'Men of Color, To Arms!' 172

Narrative of the Life of Frederick Douglass, an American Slave, Written by Himself 172

Dower, John W. 72

War without Mercy 42

Du Bois, W. E. B.

on atomic bomb 149

'The Comet' 120

on interracial sexual relations 106

and invisibility 123

peace activism 170

Dutt, Soshee Chunder: ‘The Republic of

Orissa' 203

dystopia 69-70

East India Company 64

ecological disasters 166

Ehrhart, W. D. 240

Einstein, Albert 185, 190
Eisenhower, President Dwight 59, 111

Ellison, Harlan: 'A Boy and His Dog' 238-9

Ellison, Ralph Waldo: Invisible Man 123

empire 87

Engh, M. J.: Arslan 239

environment 28, 52, 60, 90-1

Ethiopia 41

ethnic diversity 127-8, 181

ethnicity $11-12$

eugenics 26-7

Europe 61, 157, 162, 217-18

Evans, Joyce A. 51

evolution see Darwin, Charles

extraterrestrial-human encounters 135-6

Fail Safe (film) 50

fame 67

family record albums 27

famine victims 158-9

Fanon, Frantz 107

Fellowship of Reconciliation 169

feminism, black 171

film industry, Cold War 9

Fitting, Peter 95, 103n24

Fitzgerald, F. Scott: 'Echoes of the Jazz Age' 49

Five (film) 125-6

Fleming, Ian

Thunderball 230

You Only Live Twice 230, 231-3

Foertsch, Jacqueline 112-13, 117, 118-19

Foreman, Carl 228

Forman, James D.: Doomsday Plus Twelve $84 n 90$

Fortress Europe 217

Foucault, Michel 11

France 13, 29

Franco-Prussian War 29

Frank, Pat: Alas Babylon 115-20

Franklin, H. Bruce 34

War Stars 44, 54

freedom 147

frontier novels 58

future war fiction 29-38

Gaddafi, President Muammar 224

Gaiman, Neil: The Sandman 86-7

Galton, Sir Francis 26, 27

Gandhi, Indira 206

Gandhi, Mohandas K. 206, 208-9

Garvey, Marcus 43

gated communities 73

Geisel, Theodor Seuss 42

genocide 32, 38

African-Americans 155

Dawn (Butler) 139-40

Nazis 42, 52, 109

racial 156, 168, 198 see also Holocaust

Triumph (Wylie) 129

George, James: Ocean Roads 188 
Germany 27-8, 39, 41, 68, 69 see also Prussia Gibbons, Floyd: The Red Napoleon 36

Gibson, Ross 91, 96

Giesy, John Ulrich: All for His Country 35

Gilroy, Paul 52, 108, 149

After Empire 92

The Black Atlantic 147

Ginsberg, Allen: 'Beginning of a Poem of These States' 238

Gobineau, Joseph Arthur, Count de 10

Godden, Richard 107

Grant, Madison: The Passing of the Great Race 27

Gray, Richard: A History of American Literature 173

Great Depression 49

Griffith, George

The Angel of the Revolution 33

The Great Pirate Syndicate 32-3

Gunesekera, Romesh: The Sandglass 212-14

Halsey, Admiral William 42

Hamilton, George 88

Experiences of a Colonist Forty Years Ago 88

Haney López, Ian F. 11

Hansberry, Lorraine: What Use Are Flowers? 5

Hansen, Thomas Blom 212

Hassan, Mohammed bin Abdullah 39-40

Haut, Woody: Pulp Culture 9

Hay, William Delisle: Three Hundred Years Hence 31-2

Heinlein, Robert A.

The Day after Tomorrow 36

Farnham's Freehold 51

Henrikson, Margot A.: Dr. Strangelove's America 155

Herder, Johann Gottfried von 14

heroism 96-102

Hersey, John: Hiroshima 188

hierarchies

Dawn (Butler) 136

Mad Max II 100

Hindu nationalism 203, 204-7, 208, 212, 220

The Last Jet-Engine Laugh (Joshi) 210, 214 , 217,219

Sacred Games (Seth) 215

Hinduism 205-6

Hiroshima 5, 41, 44, 150, 154, 180, 188

Hispanic Americans 61, 62, 78

Hitler, Adolf 28

Hoban, Russell: Riddley Walker 93-4

Hollywood 73

Holocaust 182

homesteading 51

homophobia 137-8

Honeyford, Ray: Anti-Racism 138

Hoover, President Herbert 43

Hughes, Langston 151

'Atomic Dream' 160
The Best of Simple 159

'Bomb Shelters' 161

'Bones, Bombs, Chicken Necks' 152

'Harlem' 155

'High Bed' 167

'Lunch in a Jim Crow Car' 155

'The Moon' 166

'Not Colored' 150-1

'Radioactive Red Caps' 155, 159-60

'Simple and the Atomic Bomb' 152

Huxley, Aldous: Ape and Essence 85

hydrogen bombs 165

immigration 217

incendiary bombs 41

India 63

Ayodhya mosque 207, 209

Bharatiya Janata Party (BJP) 206-7, 208, $214,216-17,218,220$

Christians 207

modernity 19

nuclear tests 207-9

nuclear weapons 202, 212, 220

The Last Jet-Engine Laugh (Joshi) 204, 210 11

Sacred Games (Seth) 216

Sangh Parivar organization 207, 208

Swayamsevak Sangh (RSS) 206

VHP organization 207

see also Hindu nationalism

Indian Independence Movement 205, 206, 219

Indian National Congress 206

International School of Nuclear Science and Engineering 227

interpretation 3

Invaders from Mars (film) 166

Iran 240

Iraq 40, 244, 245

Irish Americans 12

irony 235

Irving, Washington: History of New York 53-4

Islam 39-40 see also Muslims

Jameson, Fredric 3

Jan Sangh Party (India) 206, 207, 219

Japan

American aid to 68

atomic bombing of 5, 41, 44, 148, 152 see also Hiroshima; Nagasaki

fear of 33-4, 35, 36, 38, 41-2, 43-4

markets 68-9

Warday and the Journey Onward (Strieber and Kunetka) 72

You Only Live Twice (Fleming) 232

Jaskoski, Helen 191, 193

Jews

concentration camps 188

Manhattan Project 180-1

see also anti-Semitism; Holocaust 
Johnson, Dennis: Fiskadoro 54

Joplin, Janis 66

Jordan, June

'From Sea to Shining Sea' 173-4

'Who Would Be Free, Themselves Must Strike the Blow' 171-2, 173

Joshi, Ruchir: The Last Jet-Engine Laugh 2035, 209-12, 214, 216-19

Juergensmeyer, Mark 208

Kaltenborn, H. V. 180

Kanon, Joseph: Los Alamos 182, 196

Kashmir 208

Kawada, Louise 173

Kennedy, President John F. 2, 162, 165, 232

Kennedy, Robert F.: 13 Days 232

Kerslake, Patricia: Science Fiction and Empire 6

Kinchy, Abby J. 170

King, Coretta Scott 170

King, Martin Luther, Jr 147, 151, 169-70

Kipling, Rudyard 64-5

Kornbluth, C. M.: 'Two Dooms' 43-4

Kovel, Joel: Against the State of Nuclear Terror 241

Ku Klux Klan 37

Kunetka, James W. see Strieber, Whitley and Kunetka, James W.

Langbehn, Julius: Rembrandt as Educator 28 language

Africans 64

Biblical 194

of difference 184

Jordan, June 171-4

The Last Jet-Engine Laugh (Joshi) 214, 219 , 220

Mad Max Beyond Thunderdome (film) 93-4

'Mont Blanc' (Brathwaite) 156-9

Nazi 52

normalizing role $7-8$

of poetic justice 187

of racism 189, 198

Lanz, Jörg 28

Le Queux,William: The Invasion of 191030

League of Nations 127

Lebensraum 58

Lefebvre, Henri 85

Leghorn, Richard S. 165, 226-7

Lévi-Strauss, Claude 106-7

Linnaeus, Carolus: Systema Naturae 10

List, Guido von: German Mythological Landscape Pictures 28

London, Jack: 'The Unparalleled Invasion' 34-5

Los Angeles 71-2, 73-4

love 131-2

Luckhurst, Roger 139

MacCannell, Dean 111-12

McClintock, Anne 217
McClure's Magazine 34

McConachie, Bruce: American Theater in the Culture of the Cold War 9

Macdonald, Andrew: The Turner Diaries 108-9

McDonald's: in Swanwick's 'The Feast of Saint Janis' 75

McFarlane, Brian 94

MacLeish, Archibald: J.B. 112

Mad Max Beyond Thunderdome (film) 85 colonization 90-6

heroism 91, 94, 96-102

Marvel Comics comparison 96-7

Western motif 97

Mad Max II (The Road Warrior) (film) 98

Maddock, Shane J. 224

Nuclear Apartheid 225

Mahabharata 202

Mailer, Norman: 'The White Negro' 149

Malcolm X 150

Manhattan Project 180

The Accident (Masters) 183-9

Los Alamos (Kanon) 194-9

Ocean Roads (George) 188

Stallion Gate (Smith) 189-94

Manson, Marston: The Yellow Peril in Action 35

mapmaking 87-8

Marshall Plan 228

Marx, Karl 75, 76, 190

mass culture 114-15

Masters, Dexter: The Accident 181, 183-9

Melville, Herman: Moby Dick 89, 235

Meredith, James 2

Milius, John 239

Miller, George 94

Miller, Walter M.: A Canticle for Leibowitz 134

Miller, Walter M., Jr 241-2

miscegenation see sexual relations, interracial Mitchell, Clarence, Jr 154-5

mixed race people 106

modernity

Australia 101

Europe 88, 89

hypocrisies/tensions 174

India 19

nuclear 162-5

opposition to $236-7$

racial oppression and 147, 148, 151, 152, 156, 157, 158-9

technical emancipation 167

warfare 29

World War Three 2

Moore, Ward

Lot 115

Lot's Daughter 115

Morrison, Toni 79

Mosley, Walter 167

Mosse, George L.: Towards the Final Solution 27,28

The Mouse That Roared (film) 228-9

Moylan, Tom: Scraps of the Untainted Sky 69-70 
mulattoes 107

Muller, Julius W.: The Invasion of America 367

music $9,66,95,100,160$

Muslims

India 207, 215, 216

as a threat $218,240,243,244$

see also Islam

Mutually Assured Destruction 229

Nadel, Alan 244

Containment Culture 8-9

Nagasaki 5, 41, 44, 180, 188

Nama, Adilifu 121, 122

napalm 157

NASA 151

nationalism: and racism 14-15

nationhood 14, 157

Native Americans 55, 56-8, 61, 62 Stallion Gate (Smith) 190-1, 193-4

Tomorrow! (Wylie) 113

Warday and the Journey Onward (Strieber

Nazis and Kunetka) 78

The Accident (Masters) 184-5

and anti-Semitism 180

fear of 38

Los Alamos (Kanon) 195-6

and race $12,27,52$

Negro World (newspaper) 43

Nehru, Jawaharlal 206

Nelson, Alondra 234

Nelson, William Xavier 114

neocolonialism 68

'New World' 163

New Zealand 85

Newman, Kim

Apocalypse Movies 96

Cherry 51

Neon City 51

World Gone Wild 51

Nixon, President Richard 67

Nordau, Max: Degeneration 26

Norton, Roy: The Vanishing Fleets 35

Nowlan, Philip Francis

The Airlords of Han 37

Armageddon 2419 A.D. 37

nuclear arms race 165

nuclear attack survivors 112

nuclear criticism 6-9

nuclear deterrence 229

nuclear disarmament 151, 229

nuclear fallout 153-4, 159

nuclear fission 166

nuclear physics 165

nuclear technology 1-2, 227

nuclear testing 87, 171, 207-9

nuclear war 7

Alas Babylon (Frank) 115-20

criticisms 8
Dawn (Butler) 137, 140

The Last Jet-Engine Laugh (Joshi) 209

The Shoes of the Fisherman (West) 238

Triumph (Wylie) 128, 129

The Turner Diaries (Macdonald) 109

Warday and the Journey Onward (Strieber and Kunetka) 61-2

The World, The Flesh and the Devil 124

nuclear weapons $7,79,170$

Cat's Cradle (Vonnegut) 233

Deterrence (TV film) 245

'dirty' 245

India 202, 207-9, 212, 220

The Last Jet-Engine Laugh (Joshi) 210-1 1

Sacred Games (Seth) 216

nonproliferation 224-5

Pakistan 207, 208

Russia 242

Sri Lanka 212-14

as weapons of mass destruction 228

You Only Live Twice (Fleming) 232, 233

Odell, Samuel W.: The Last War 32

Office of Civil and Defense Mobilization 159

oil 93

On the Beach (film) 85 see also Shute, Nevil:

On the Beach

Oppenheimer, J. Robert

portrayals of 182, 189, 190, 193, 197

on Trinity atomic bomb test 202, 220

O'Regan, Tom 91

Organization of Petroleum Exporting Countries (OPEC) 93

outer space 51

Pakistan 204, 207, 208, 216

Pape, Robert A. 41

Parivar, Sangh: The Saffron Wave 212

Peace Information Center 170

Pearson, Karl: Francis Galton 26-7

Phillips, William 43

Pick, Daniel 25-6

Piette, Adam: The Literary Cold War 9

poetry, Cold War 9

'Poets against the End of the World' event, New York City (1982) 171

Polo, Marco 87

prejudice 138

Preston, John 111

Project Orion 165

Prussia 29

psychotherapy 77

Public Enemy (rap group): 'Fear of a Black Planet' 105

Pugwash Conference, Third (1958) 227-8

race $10-11,113-14,198-9$ see also cultural differences

race scientists $10-11$

racial cleansing 27-8 
racial degeneration 30, 44

racial desegregation

Alas Babylon (Frank) 116, 119-20, 122

Triumph (Wylie) 129, 130

racial difference 136

racial equality 170

racial justice 151

racial Otherness 191-2

racial physiology 195, 198

racial politics $124-5$

racial purity 105-6, 110, 114

racial segregation $155,159-62$

Five (film) 125

The Martian Chronicles 133

Simple stories (Hughes) 159-60, 166

see also racial desegregation

racial terror $148,149,150$

racialized symbols 36

racism $78-9$

anti-black 43, 155, 168

Britain 138

Chinese 238

'Dark Interlude' 108

Dawn (Butler) 137-8, 139

Five (film) 125

'High Bed' (Hughes) 167

Los Alamos (Kanon) 182

Mad Max Beyond Thunderdome (film) 94

Marshall Islanders 152, 159

and nationalism 14-15

Native Americans 59-60

Stallion Gate (Smith) 191

Triumph (Wylie) 128

United States 181

World War II 42

see also anti-Semitism; xenophobia

radiation $171-2$

radioactive fallout see black rain

Rawlinson, Mark 39

Raymond, Alex: Flash Gordon 37-8

Rayner, Jonathan 97

Reagan, President Ronald 136, 240

Red Dawn (film) 239

Reed, Ishmael 13 Mumbo Jumbo 151, 163-5

Reed, Peter J. 235

Reed, Samuel Rockwell: The War of 1886, between the United States and Great Britain 30

religion see Christianity; Hinduism; Islam

Renan, Ernest 13

Reynolds, Mack see Brown, Frederic and Reynolds, Mack

Rhodes, Cecil 31, 165

Richards, Leo: 'Where Are Your Worshippers' 154

Rieder, John 11, 30, 34

Colonialism and the Emergence of Science Fiction 6-7

Ringer, Gerald J. 169

ritual 76
Robeson, Paul 170

Robinson, Donald: 'If H-Bombs Fall...' 154

Robinson, Kim Stanley: The Wild Shore 69

rockets 165

Roediger, David R.: The Wages of Whiteness $12-13$

Rogers, Gwendolyn 171

Rohmer, Sax 38

Roosevelt, President Franklin D. 127

Roosevelt, President Theodore 27, 31

Roshwald, Mordecai: Level 7 103n20

Rotter, Andrew J. 44, 224

Rowlandson, Mary: A Narrative of the Captivity and Restoration of Mrs. Mary Rowlandson 77

Roy, Arundhati

on Hindu nationalism 220

on India 219

on The Last Jet-Engine Laugh (Joshi) 214

on nuclear nationalism 202, 205, 212

on nuclear weapons 211

Race, Ethnicity and Nuclear War 1

Rushdie, Salman: The Moor's Last Sigh 215

Russell, Bertrand 161-2

Russia/Russians 189, 242 see also USSR

Russo-Japan War 33

Rustin, Bayard 169-70

Said, Edward: Orientalism 63

Savarkar, V. D. 205-6

Schaub, Thomas H. 148-9

American Fiction in the Cold War 9

Scheckels, Theodore F. 96

Schlesinger, Arthur 3

Schuler, Alfred 28

Schuyler, George S. 166

Schwartz, Richard A. 119

science fiction: origins of 11

scientific knowledge 77-8 see also technology

Scott, Jonathan 136

Scruton, Roger: The Meaning of Conservatism 138

Seed, David 34, 37, 49, 78, 112

Senior, Olive: 'rain' 153

sexual relations, interracial 106-10

Alas Babylon (Frank) 119

'The Comet' (Du Bois) 120

Dawn (Butler) 135, 140

Five (film) 125

Jimmy Corrigan: The Smartest Kid on Earth (Ware) 120

Los Alamos (Kanon) 198

Stallion Gate (Smith) 191-2, 192-3

Tomorrow! (Wylie) 113-14

Triumph (Wylie) 130

The World, The Flesh and the Devil (film) 121,122

Shapiro, Jerome F. 93, 242

Sharp, Patrick B.

on Alas Babylon (Frank) 117

on A Canticle for Leibowitz (Miller) 134 
on civil defence 111,159

on 'Radioactive Red Caps' (Hughes) 160

Savage Perils 7, 50, 51-2

on Stallion Gate (Smith) 194

on Tomorrow! (Wylie) 112

on 'The Unparalleled Invasion' (London) 34

Shaw, Tony 229

British Cinema and the Cold War 9

Hollywood's Cold War 9

Shelley, Percy Bysshe: 'Mont Blanc' 156-9

Sherman, General William 58

Sherriff, R. C.: The Hopkins Manuscript 38

Shiel, M. P.: The Yellow Danger 33

Shiv Sena (Indian political party) 207

Shohat, Ella 15, 244

Shoup, David 230

Shute, Nevil: On the Beach 226 see also On the Beach (film)

Siegel, Barbara and Scott: Firebrats 51

Silko, Leslie Marmon: Ceremony 52-3

Sinker, Mark 148

skin colour: The Last of the Mohicans (Cooper) 65

slavery

black 13, 106, 107, 164, 172, 233

Dawn (Butler) 135

and western civilization 147

Smith, Barbara 171

Smith, Darryl A. 123

Smith, Martin Cruz: Stallion Gate 181-2, 18994

Social Darwinism 25

'soft places' 86-90, 101

Sollors, Werner 12-13, 217

Beyond Ethnicity 109

Soviet Union see USSR

space race 151, 166

Sputnik 1165

Sri Lanka 212-14

Stam, Robert 15, 244

Star Trek (TV series) 51, 108

Star Wars nuclear defence system 240

stereotypes

African-American 149

Australian 91, 92-3, 232-3

British Raj 64

class 93

gender 149,167

Jewish 186-7

Muslim 243

Native American 56, 65, 192

racial 234, 235-6, 237

World War II 42

Stevenson, President Adlai 59

'Stochastic' see Donnelly, Henry Grattan

Stockton, Frank: The Great War Syndicate 32

Stoddard, Lothrop 33

Stone, Albert E. 173

Literary Aftershocks 148-9, 233
Strieber, Whitley and Kunetka, James W.: Warday and the Journey Onward 49, 50, 53, 57, 61-2, 68, 69, 70-4, 77-8

Strieber, Whitley: Wolf of Shadows 56 survival: and empathy 148-9

suspense 5

Swanwick, Michael: 'The Feast of Saint Janis' 49, 50, 53, 57, 62-8, 69, 70, 71, 747, 78-9

Swarmy, Arun K. 205

Swing, Raymond Gram 180

Switzerland 14

Szilard, Leo 185, 225, 230

Talbott, Strobe 202, 203

Tank Girl (comic) 85

technology

Cat's Cradle (Vonnegut) 233-4

nuclear 167, 173

and survival 52-3, 65-6

Western and Non-Western 164

see also scientific knowledge

Tenn, William: 'Eastward Ho!' 49, 50, 53, 57-9, 60-1, 77, 79

terrorists, Islamist 244, 246

Test Ban Treaty (1963) 165

Thackeray, Balasaheb K. 208

the English: American representations of 30

Theosophy $27-8$

Third World 225, 226, 234, 24l-2 see also

India; Pakistan; Sri Lanka

Threads (TV film) 240

Time magazine 181

Tomorrow Never Dies (film) 242-3

total war 29

Trenchard, Hugh M. 39, 40

True Lies (film) 243-4

Truman, President Harry S. 42

Turner, Frederick Jackson: 'The Significance of the Frontier in American History' 60-1

Turner, Tina 91-2, 96, 101

24 (TV series) 245-6

USSR 78, 165, 224-5, 240

United States

Act to Preserve Racial Integrity (Virginia) (1924) 13

aerial attacks on 40-1

aerial warfare 39

American Exceptionalism narrative 57

anti-Semitism 183-9

and Australia compared 89

Brown v. Board of Education of Topeka, Kansas 59, 125

Chinese Exclusion Act (1882) 30

civilization $78,107,182$

colonialism 68

Cuban Missile Crisis (1962) 224-5

demography 111

economy 68-9, 71, 79 
ethnic diversity 181

foreign policy 246

invasion of (Red Dawn) 239

Manhattan Project 166, 180

Manifest Destiny narrative 57

national identity 109-10

national unity 78

nationhood 157

racism 181

social injustices 173, 174

Soviet missile crisis 224-5

Test Ban Treaty (1963) 165

urban space 73

United States Air Force 165

United States Federal Civil Defense Administration (FCDA) 159

Until the End of the World (film) 89-90

urban planning 112

Vajpayee, Atal Bihari 206, 207, 208

Victory through Air Power (film) 41-2

Vienna Declaration (1958) 228

Vietnam War 67, 157, 238-9

Vint, Sherryl 135

violence

absolute 229

against African Americans 149, 150

Dawn (Butler) 137-8

globalized 85

India 206, 207

Mad Max films 95, 97-8

Pakistan 207

'The Feast of Saint Janis' (Swanwick) 667, 68

Voices (magazine) 154

Vonnegut, Kurt, Jr: Cat's Cradle 233-7

Wachhorst, Wyn 122

Wagar, W. Warren 33

Walcott, Derek: 'The Muse of History' 151, 163

Walkabout (film) 89

Walker, Alice 165-6, 168

Wallace, King: The Next War 32

Wallerstein, Immanuel 14-15

Walt Disney studios: Victory through Air Power 41-2

War on Terror 246

Ware, Chris: Jimmy Corrigan: The Smartest Kid on Earth 120

weapons of mass destruction 228, 245

Weinberg, Alvin M.: 'Prospects in International Science' 227

Wells, H. G.

The War of the Worlds 54

The World Set Free 36, 112

West, Morris: The Shoes of the Fisherman 238

Western motifs 97, 113, 116

White, Arnold: Efficiency and Empire 26

White, Walter 180 white supremacism 1-2, 3, 44

atomic bomb and 154-5

A Canticle for Leibowitz (Miller) 134

future-war fictions 246

'Mont Blanc' (Brathwaite) 157

sexual relations, interracial 107

Triumph (Wylie) 129

United States 12

Walker, Alice on 165-6, 168

Warday and the Journey Onward (Strieber and Kunetka) 78

Whitfield, Stephen J.: The Culture of the Cold War 8

Whitney, Atwell: Almond-Eyed 30-1

Wilkins, Roy 180

Williams, John A.: Captain Blackman 155

Wilson, Steve: The Lost Traveller 54-7

Wodehouse, P.G.: The Swoop! 30

Wolfe, Bernard: Limbo 112

Wolfe, Gary K. 50

Wolfe, Harold 85

women

Alas Babylon 118-19

black feminism 171

interracial sexual relations 106, 107

Mad Max trilogy 91-3, 94, 95-6, 101

oppression 173

slavery 106

stereotypes 235

Tomorrow! (Wylie) 113

Triumph (Wylie) 127-8, 129-30

white American 35-6

The World, The Flesh and the Devil (film) 120-3

World Peace Appeal 170, 171

World War I 39, 228

World War II 39, 41-2

World War Three 2, 162

On the Beach (Shute) 226-7

racial causes 241

Third World 225, 241-2

Threads (TV film) 240

Western and Central Asia 240

Wright, Frank Lloyd 126, 132

Wylie, Philip

Tomorrow! 112-15

Triumph 85, 126-32

xenophobia 139 see also anti-Semitism; racism

Yellow Peril fictions 30-1, 238-9

Yost, David: The US and Nuclear Deterrence in Europe 242

Zangwill, Israel: The Melting-Pot 109-10

Žižek, Slavoj 246 